\title{
Conference Edition
}

European Union Agency for

Fundamental Rights

Annual Report

2010 



\section{European Union Agency for Fundamental Rights}

\section{Annual Report}

Conference Edition 



\section{Foreword}

The Annual Report 2010 covers events and developments in the area of fundamental rights in the European Union during 2009. It is the first annual report to be published since the entry into force in December 2009 of the Treaty of Lisbon, which has significantly strengthened the protection of fundamental rights at a EU level.

The report encompasses the full range of fundamental rights issues now covered by scope of the FRA mandate since it was expanded in March 2007. While the areas of the former EUMC mandate - namely racism, xenophobia, and issues related to migrants and minorities - still figure prominently in this report, there is also coverage of those broader thematic areas that are represented in the Agency's Multi-annual Framework adopted in February 2008. These can be found in sections of the report covering, in turn: discrimination based on sex, disability and sexual orientation; the rights of the child and protection of children; immigration and border control; access to justice and victim compensation; participation of EU citizens in the Union's democratic functioning, and information society, respect for private life, and protection of personal data.

This report draws on data and information collected by the Agency's RAXEN National Focal Points (NFPs) and its FRALEX group of senior legal experts in each of the 27 Member States of the EU, as well as on the findings of primary research projects carried out by the Agency itself. The Agency's various research projects are referred to throughout the report at points where the findings are directly relevant to the thematic areas being discussed. These findings, rooted in research and expert analysis, enable comparisons to be made between all 27 Member States, and also provide evidence upon which future policies can be based.

Valuable sources of information for this report also continue to derive from various institutions and mechanisms established by the Council of Europe. Examples of fruitful cooperation between the FRA and the Council of Europe include the common project on Roma migration and Roma movement that was finalised in 2009. In early 2010, the Agency concluded an agreement with the European Court of Human Rights to work on a joint project with the aim of publishing a case-law handbook on European non-discrimination. Deliverables such as these add further strengths to a complimentary relationship that provides the European landscape of fundamental rights protection with reliable data and solid findings. 
We would like to thank the Management Board of the FRA for their diligent overseeing of the Annual Report process, and the Scientific Committee of the FRA for the advice they provided on the report in its early stages.

We also take this opportunity to thank the staff of the FRA for their commitment and hard work on this and all the other FRA projects during the year.

Ilze Brands Kehris

Chairperson of the

Management Board
Morten Kjaerum

Director of the FRA 


\section{Contents}

Foreword

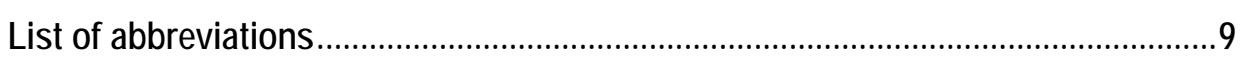

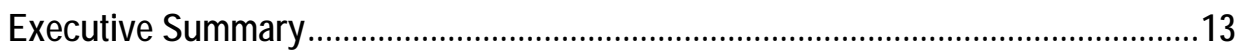

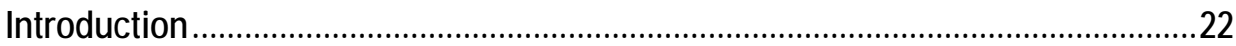

1. Equality bodies and complaints mechanisms under the

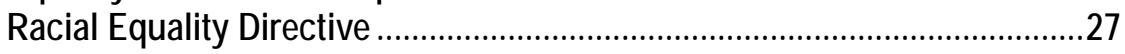

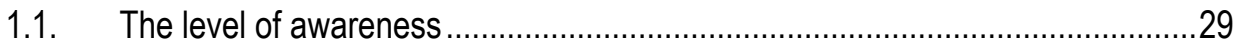

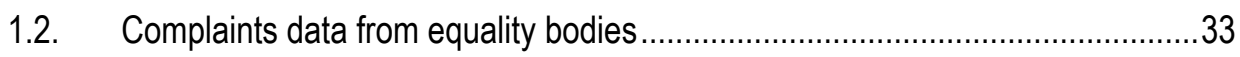

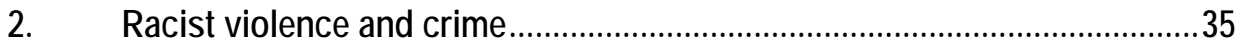

2.1. Effective means to assess the extent and nature of the problem ......................35

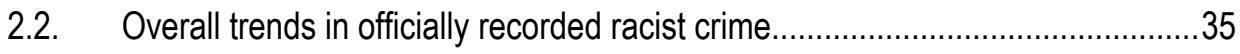

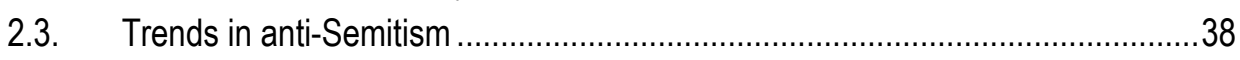

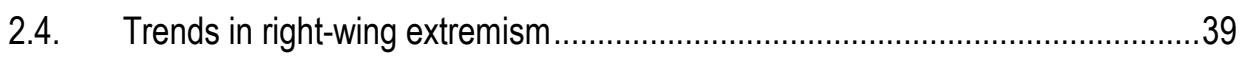

2.5. EU-MIDIS: filling a gap in current knowledge .............................................. 40

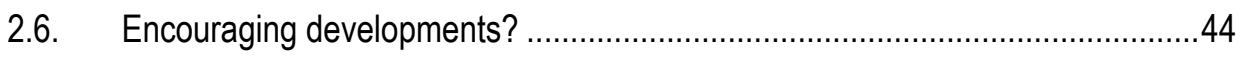

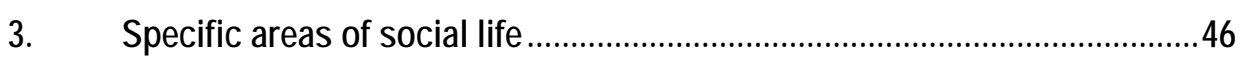

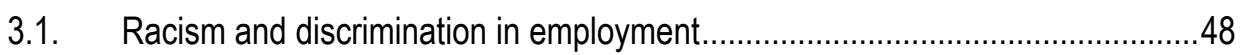

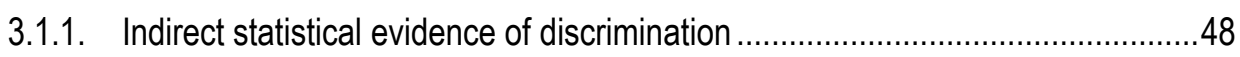

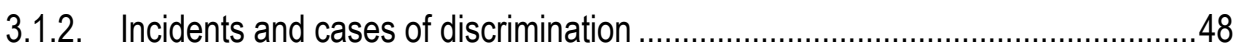

3.1.3. Surveys of minorities and the majority population .........................................51

3.1.4. Discrimination testing............................................................................52

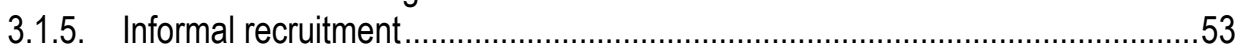

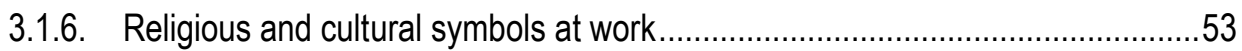

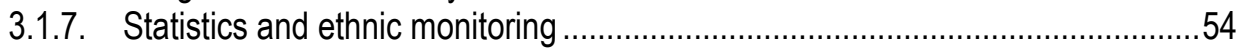

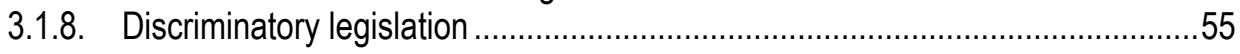

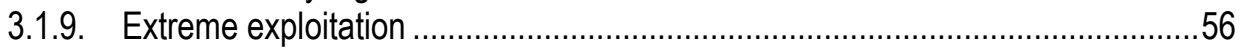

3.2. Racism and discrimination in the housing sector .........................................59

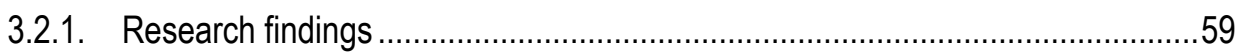

3.2.2. Discrimination and advertisements .........................................................61

3.2.3. The housing situation of Roma and Travellers .............................................62

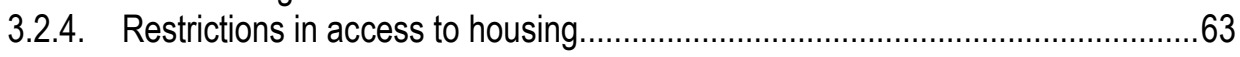

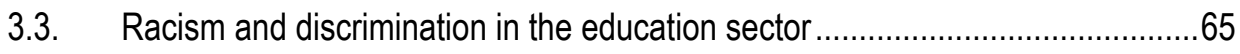

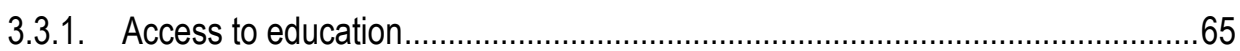

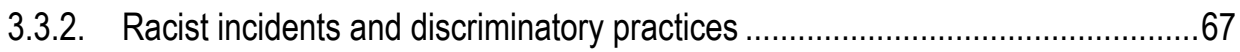

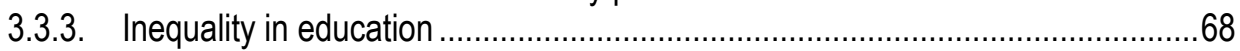

3.3.4. Issues and debates concerning discrimination and exclusion in education .......69 
3.3.5. Support measures and good practice activities ..............................................

3.4. Racism and discrimination in the healthcare sector.......................................75

3.4.1. Access to healthcare for irregular migrants and asylum seekers .....................75

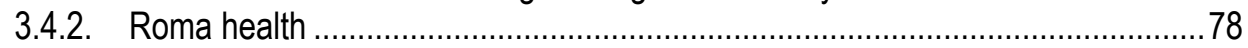

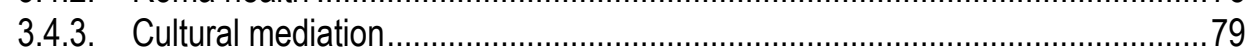

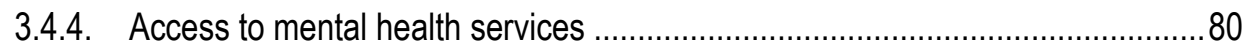

3.5. Migrant and minority issues in other areas of social life ....................................... 81

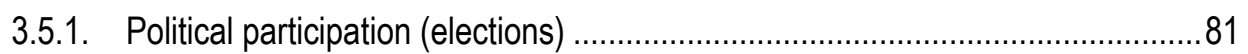

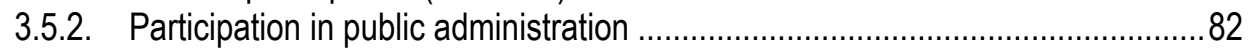

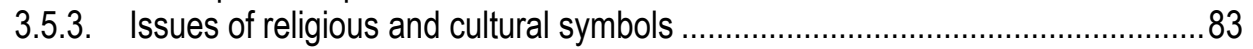

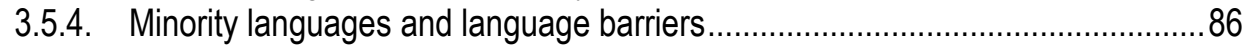

3.5.5. Negative discourse on minorities, including during elections............................89

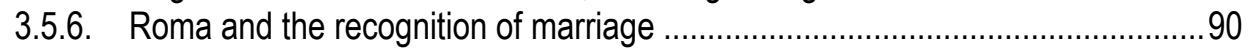

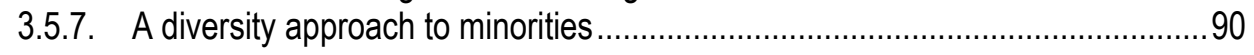

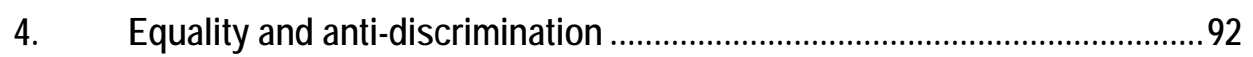

4.1. Discrimination on grounds of sexual orientation and gender identity...............92

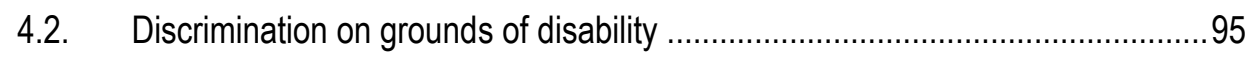

4.2.1. Convention on the rights of persons with disabilities ......................................95

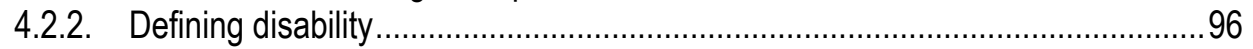

4.2.3. Progress with proposal for a 'horizontal' directive...........................................96

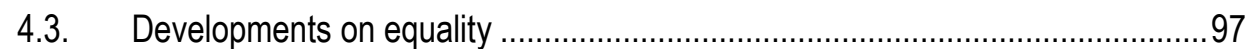

4.3.1. Commission communication on health inequalities .....................................99

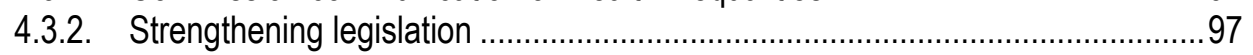

4.3.3. Linking ethnic origin with nationality ………................................................ 99

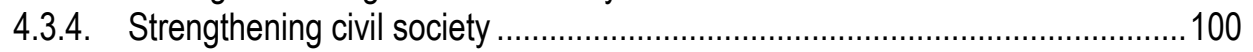

4.3.5. Equal treatment between women and men .................................................. 101

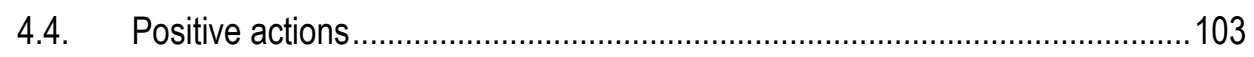

5. The rights of the child and protection of children ..................................104

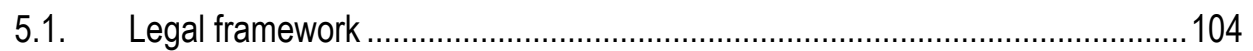

5.1.1. UN Convention and policy guidelines .......................................................... 104

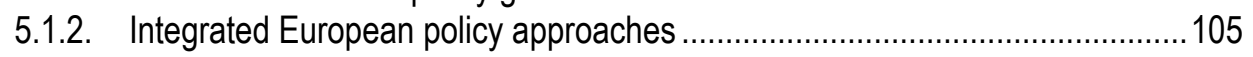

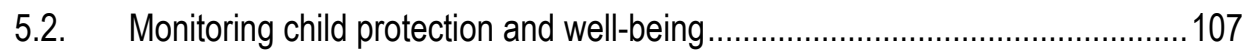

5.2.1. Establishing an analytical framework.............................................................107

5.2.2. Care and the prevention of violence against children .....................................109

5.3. Developments at EU and national level ...............................................112

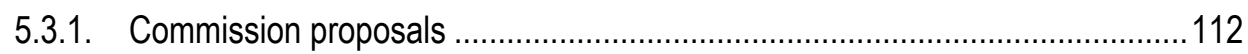

5.3.2. Protection at Member State level........................................................114

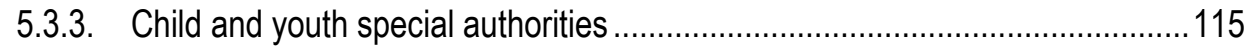

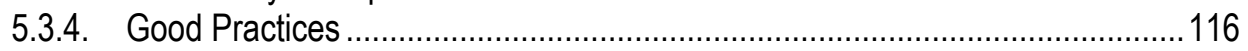


6. Immigration and border control ......................................................118

6.1. Asylum, immigration and integration of migrants .........................................118

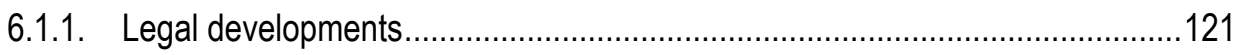

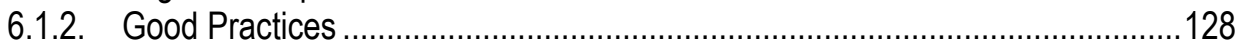

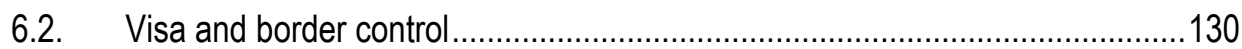

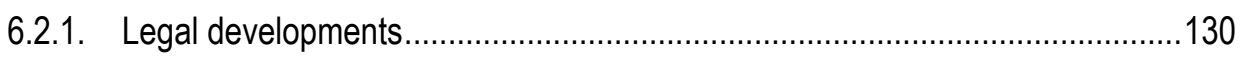

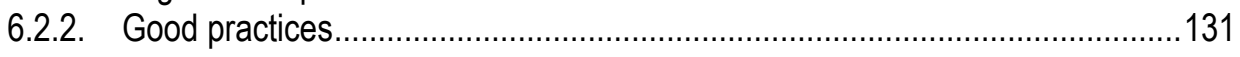

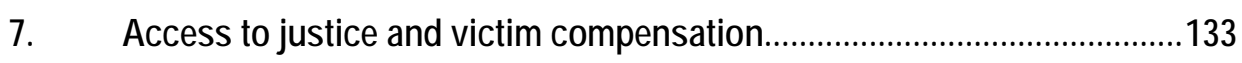

7.1. Access to efficient and independent justice ...............................................133

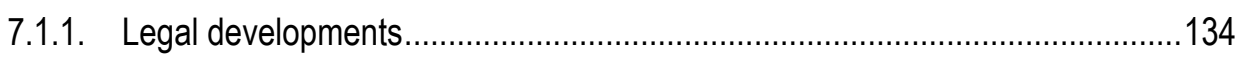

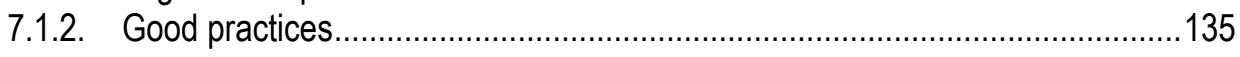

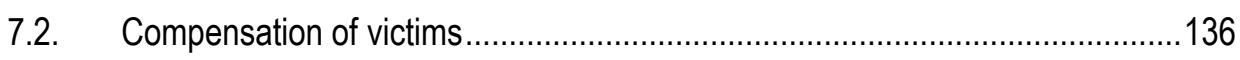

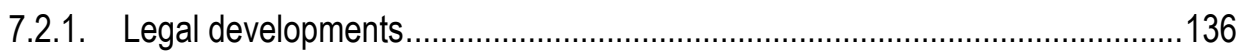

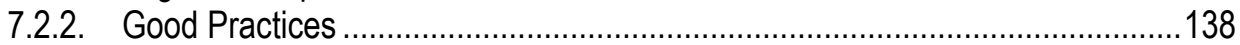

8. Participation of the citizens of the Union in the Union's democratic functioning .......................................................................140

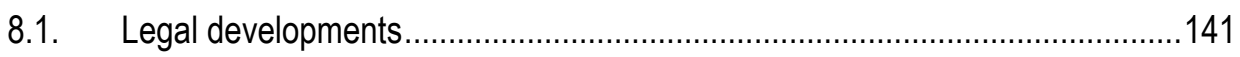

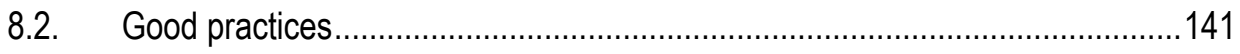

9. Information society, respect for private life and protection of

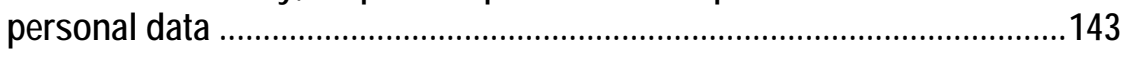

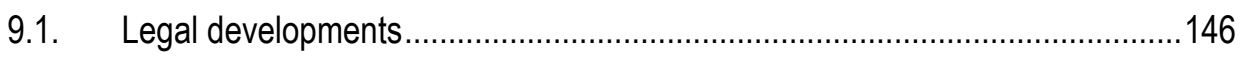

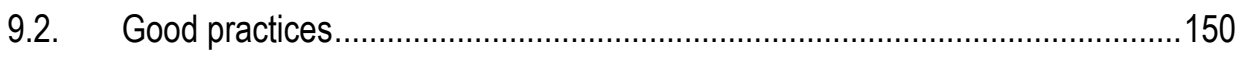

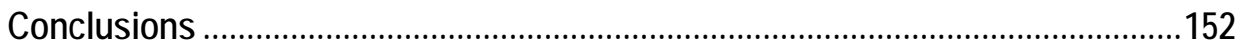

Annex 1: International human rights instruments ............................................162

Annex 2: Country codes............................................................................171 
European Union Agency for Fundamental Rights Annual Report 2010 


\section{List of abbreviations}

ADB

ADNB

ADR

ALARM

APA

ASGI

$\mathrm{BBC}$

BGG

$\mathrm{BHC}$

BMUKK

CEDAW

CEOOR

CERD

CMU

CNPD

CommHR
Anti-Discrimination Bureau (the Netherlands)

Landesstelle für Gleichbehandlung - gegen Diskriminierung, (anti-discrimination office, Germany)

Alternative Dispute Resolution

Action pour le Logement Accessible aux Réfugiés à Molenbeek (Action for Accessible Housing for Refugees in Molenbeek, Belgium)

Aliens' Police Act (Fremdenpolizeigesetz - FPG, Austria)

Associazione Studi Giuridici sull'Immigrazione (association for legal studies on immigration, Italy)

British Broadcasting Corporation

Behindertengleichstellungsgesetz (Act on Equal Opportunities for Disabled Persons, Germany)

Bulgarian Helsinki Committee

Bundesministerium für Unterricht, Kunst und Kultur (Ministry for Education, Arts and Culture, Austria)

United Nations Committee on the Elimination of Discrimination against Women

Centre for Equal Opportunities and Opposition to Racism, Belgium

UN Committee on the Elimination of Racial Discrimination

Couverture Maladie Universelle (universal health insurance system, France)

Commission nationale à la protection des données (National Commission on Data Protection, Luxembourg)

Council of Europe Commissioner for Human Rights 
CPT European Committee for the Prevention of Torture and Inhuman or Degrading Treatment or Punishment

CRC Convention on the Rights of the Child

CRPD Convention on the Rights of Persons with Disabilities

CTI Czech Trade Inspection (Česká obchodní inspekce, Czech Republic)

DACoRD Dokumentations- og rådgivningscenteret om racediskrimination (Documentation and advice centre on racial discrimination, Denmark)

DIER Department of Industrial and Employment Relations. (Malta)

DIHR Danish Institute for Human Rights (Institut for Menneskerettigheder )

EAD Impulsbeleid Evenredige Arbeidsdeelname en Diversiteit (Impulse-Policy Proportional Work Participation and Diversity, Belgium)

ECHR European Convention on Human Rights

ECJ Court of Justice of the European Union (formerly the European Court of Justice)

ECPAT End Child Prostitution, Child Pornography and Trafficking of Children for Sexual Purposes

ECRI European Commission against Racism and Intolerance

ECRML European Charter for Regional or Minority Languages

ECtHR European Court of Human Rights

EHRC Equality and Human Rights Commission (UK)

EMN $\quad$ European Migration Network

ENOC European Network of Ombudspersons for Children

EPSCO Employment, Social Policy, Health and Consumer Affairs Council

ERA Equality \& Rights Alliance (Ireland) 
ETC Equal Treatment Commission (Commissie gelijke behandeling, the Netherlands)

EU-MIDIS European Union Minorities and Discrimination Survey (FRA)

FCNM Framework Convention for the protection of National Minorities

FRA European Union Agency for Fundamental Rights

FRALEX Fundamental Rights Agency Legal Experts (FRA)

HALDE Haute autorité de lutte contre les discriminations et pour l'égalité (Equal Opportunities and Anti-Discrimination Commission, France)

HCNM High Commissioner on National Minorities (OSCE)

HSB Hyresgästernas Sparkasse och Byggnadsförening (Tenants Savings and Building Society, Sweden)

INED Institut national d'études démographiques (National institute for demographic studies, France)

LGBT Lesbian, gay, bisexual and transgender

LIBE Committee on Civil Liberties, Justice and Home Affairs of the European Parliament

LRC Law Reform Commission (Ireland)

MAF Multiannual Framework (FRA)

MAT Muslim Arbitration Tribunal (UK)

NCCRI National Consultative Committee on Racism and Interculturalism (Ireland)

NFP National Focal Point (FRA)

NGO Non-Governmental Organisation

ODIHR Office for Democratic Institutions and Human Rights (OSCE)

OSCE Organization for Security and Co-operation in Europe

RAXEN Racism and Xenophobia Network (FRA) 
SLI State Labour Inspectorate (Valsts Darba inspekcija, Latvia)

SPRAR Sistema di protezione per richiedenti asilo e rifugiati (Protection system for asylum seekers and refugees, Italy)

StPO Strafprozessordnung (Criminal Procedure Code, Germany

TEU Treaty of the European Union

TFEU Treaty on the Functioning of the EU

UNHCR UN High Commissioner for Refugees

UNICEF United Nations Children's Fund

VCA Victims of Crime Act (Verbrechensopfergesetz VOG Austria)

ZfT Zentrum für Türkeistudien (Centre for Turkish Studies, Germany) 


\section{Executive Summary}

The entry into force of the Treaty of Lisbon at the end of 2009 has significantly strengthened the protection of fundamental rights at European level. Under the new European Union (EU) treaties the EU Charter of Fundamental Rights has become legally binding, setting out in one text the civil, political, economic and social rights of European citizens and all persons resident in the EU. In this context, the Annual Report sets out some of the most significant events and developments relevant to fundamental rights during 2009.

\section{Equality bodies and complaints mechanisms}

The Racial Equality Directive (Council Directive 2000/43/EC ), the most important piece of EU legislation combating discrimination on grounds of 'race' and ethnic origin, was adopted in 2000. The Directive puts Member States under a legal obligation to designate a body for the promotion of equal treatment without discrimination on grounds of racial or ethnic origin. However, a number of Member States have been slow to comply with this obligation. By the end of 2009 there were still examples where the equality body was either missing or was so new that it had not had time to become operationally effective. For many of the equality bodies the low level of human and financial resources available to them suggests a less than strong commitment to them by the Member States.

Surveys in 2009 indicate that public awareness of the equality bodies is generally low, and that among minority groups it is even lower than for the whole population. The number of complaints of discrimination made to equality bodies were at a low level in 2009, even though the FRA's EU-MIDIS victim survey published in the same year, covering 2008, found that significant proportions of migrant and minority group members who were interviewed felt that they had been the victims of discrimination over the preceding 12 months.

\section{Racist violence and crime}

Across the EU the collection and public availability of official criminal justice data on racist crime continues to vary significantly between Member States, with some publishing no data at all, and only Finland, Sweden and the UK collecting and publishing comprehensive data on a regular basis. During the period 2000-2008, 10 of the 12 Member States which collect sufficient criminal justice data on racist crime to be able to undertake an analysis of trends experienced an upward trend in recorded racist crime.

The gap in data collection on racist crime in the majority of Member States is one of the reasons why the FRA carried out the EU-MIDIS survey of migrants and minorities. The survey's findings are in contrast with the absence or 
'undercount' of data on racist crime in the majority of EU Member States. For example, 18 per cent of all Roma interviewees and 18 per cent of all SubSaharan African interviewees in the EU-MIDIS survey indicated that they had experienced at least one incident of assault, threat or serious harassment in the last 12 months that they considered to be racially motivated.

Only some Member States collect criminal justice data on crime with an extremist right-wing motive, and it is clear that the scope of data collection should be broader than this. The EU-MIDIS data shows clearly that perpetrators of racist attacks are often 'ordinary' people - such as someone from the neighbourhood, a customer, or a work colleague - whereas members of rightwing groups were identified as perpetrators in only a limited number of incidents.

\section{Ethnic discrimination in employment}

In 2009 the area of employment continued to be identified as the area of social life where racial/ethnic discrimination was reported the most. Indirect indicators of discrimination came from statistical patterns which show inequality between migrants/minorities and the majority population despite equivalence in qualifications and other relevant criteria. Direct evidence came from incidents of discrimination, ranging from the denial of employment opportunities because of ethnic origin or skin colour, to racist harassment in the workplace. Surveys of minorities in several countries revealed subjective experiences of discrimination at work, or when looking for work, and surveys in some countries revealed negative attitudes on the part of majority population respondents to recruiting or working with people with immigrant or minority backgrounds.

In some Member States there were job advertisements which were clearly worded against minority applicants, and in several countries there were complaints about unnecessary language requirements for jobs, which suggested the operation of indirect discrimination on grounds of ethnicity. Again this year there were examples of the effects of 'discriminatory legislation' where legallyresident non-nationals are restricted by law from job opportunities in the public sector, in this case affecting nurses in a hospital.

Finally, this year there were a great many reports of extreme exploitation of migrant workers, often made possible by their legal vulnerability. There are descriptions of insecure workers suffering a range of injustices, including insults and harassments, having to work extremely long hours in unhealthy conditions in violation of labour regulations, being paid less than collective agreements, and denied sickness leave. Workers have had their passports confiscated and been confined in their sub-standard accommodation without freedom to leave, or have had the cost of their meagre accommodation and food deducted from their wages. 


\section{Ethnic discrimination in housing}

Regarding access to accommodation, there are some parallels with the area of employment. Indirect evidence for ethnic discrimination in this field comes from statistical patterns of inequality, and direct evidence comes from specific research projects, including matched pair testing experiments. In both sectors, openly discriminatory advertisements are a continuing problem.

As highlighted in previous years, Roma and Travellers are the group which is most consistently disadvantaged in private and public housing. An FRA report published in 2009 shows that this is a problem across the whole EU, and a series of reports in 2009 by the international bodies ECRI and CERD on individual Member States drew attention to the continuing social marginalisation and discrimination faced in the housing area by Roma in the Czech Republic, Slovakia, Greece, Poland, Bulgaria, and Finland.

\section{Ethnic discrimination in education}

While on a legal basis EU Member States provide open access to education, in practice, certain groups, like asylum seekers, undocumented migrants, or language minorities, face many difficulties in accessing quality education. At the same time, there are some efforts for better and fairer access to education.

In many EU Member States, there is a considerable performance gap between students with a majority background and students with a migrant or minority background. These performance gaps can partly be explained through school systems that do not counterbalance socioeconomic differences and differences in language knowledge. Differences in performance can, however, also be the result of segregation in education and discriminatory practices of school authorities and within schools.

In 2009, a range of support measures and good practice activities in the education sector were initiated by governmental institutions and civil society organisations in Member States. Measures and activities included: intercultural teacher training and support material; teacher training on and new approaches to human rights education and Holocaust education; training of Roma as teaching assistants; educational and language learning support for migrants, minorities, asylum seekers, refugees, and pupils with language or learning difficulties, integration projects in schools; desegregation projects; awareness raising projects on diversity and anti-discrimination; allocation of education or traineeship places for Roma.

\section{Ethnic discrimination in healthcare}

People who suffer the most problems in exercising their right to healthcare are irregular migrants and rejected asylum seekers, and also the Roma. Irregular migrants should in theory receive free access to emergency healthcare, and 
asylum seekers should have access to emergency health care that includes at least essential treatment of illness. However, in practice there may be obstacles in accessing healthcare. For one thing, medical personnel can act as gatekeepers restricting the access to medical care of irregular migrants and asylum seekers, and there are examples reported of undocumented migrants being denounced to the police by medical staff when trying to access emergency care.

Furthermore, there can be bureaucratic obstacles in accessing healthcare by refugees and asylum seekers, including complex application procedures and lengthy processing times. There is also a problem of a lack of awareness of the right of access to healthcare among such vulnerable groups, and also among regular migrants, caused by a lack of understanding of the medical system in the host country and insufficient communication skills.

In countries with significant Roma population, there have been reports of discrimination in their access to healthcare, and in the FRA 2009 EU-MIDIS survey, 17 per cent of Roma respondents felt that they had been discriminated against by healthcare personnel in the past 12 months.

There are practical obstacles in accessing healthcare services in culturally diverse populations, where language problems or a lack of culturally sensitive provision of health services may lead to cases of direct and indirect discrimination. In some countries there are problems in the availability of interpreters, and some Member States still do not make available general information on the healthcare system in foreign languages.

\section{Sexual orientation discrimination}

The previous Annual Report described the two major reports published by the FRA in 2009 on discrimination on grounds of sexual orientation, highlighting, amongst other things, the inadequacies and inconsistencies in legislation to protect LGBT (lesbian, gay, bisexual and transgender) people from discrimination, and the ways that such discrimination has an impact on their lives. This year's Annual Report can report both positive and negative developments in various EU Member States. For example, in Sweden, Austria and Slovenia there were government actions or legal rulings in 2009 which strengthened the rights of same sex civil partners. In Lithuania, Italy and Romania, on the other hand, there were actions or rulings in the other direction. Such developments can have implications for the enjoyment of rights, as conferred by EU law.

\section{Disability}

The Convention on the Rights of Persons with Disabilities (CRPD) was adopted by UN General Assembly resolution 61/106 of 13 December 2006, and it came into force on 3 May 2008. At the end of 2009, it had been ratified by $12 \mathrm{EU}$ Member States, and a further three more in 2010. At Member State level, a 
number of legislative initiatives were taken in order to comply with the Convention. However, no agreement was reached during 2009 regarding a European Commission proposal for a new 'horizontal' directive which would protect against discrimination outside employment on grounds of disability, as well as on grounds of religion or belief, age and sexual orientation.

\section{Positive action measures}

In the context of the inequality, exclusion or discrimination faced by various social groups in the EU, there were a number of positive action initiatives undertaken in many Member States in 2009. Positive action measures regarding the Roma, for example, are consistent with the recommendation of the UN CERD that State parties to the International Convention on the Elimination of All Forms of Racial Discrimination "take special measures to promote the employment of Roma in the public administration and institutions, as well as in private companies". One example from 2009 was in Hungary, where the Prime Minister announced a government plan to offer 200 positions to experts of Roma origin in public administration from January 2010.

In the Netherlands the imposition of positive duties on the employer to create an atmosphere favouring equal treatment became stronger in 2009, in the context of the existing policy objective that the proportion of personnel in the public sector with an ethnic minority background ('allochthonous population') should eventually rise by 50 per cent. Furthermore, half of trainee posts in civil services have been allocated to ethnic minorities. In the UK the establishment of a new House of Commons committee was agreed, with the task of producing recommendations for rectifying the under-representation of women, ethnic minorities and disabled people in the House of Commons.

In Cyprus strong positive action in the area of disability was put on the agenda in 2009, with the opening of discussions on a law introducing special provisions for the hiring of persons with disabilities in the public sector, which sets out quotas in the employment of persons with disabilities.

In two countries, Constitutional Court decisions upheld the principle of positive action. In Spain, the court rejected the claim that the establishment of gender quotas on electoral lists violated the constitutional principles of merit and ability. In Slovenia, the court similarly dismissed a claim that an Act which sets a minimum proportion of employees with disabilities constitutes a disproportionate interference with employers' freedom. These cases illustrate a growing recognition that 'merit' may be a falsely neutral criterion, and that positive action measures may be required for the effective application of the principle of non-discrimination. 


\section{The rights of the child}

The year 2009, which marked the 20th anniversary of the adoption of the UN Convention on the Rights of the Child, showed that children all too frequently remain in a vulnerable position with regard to their basic rights. In spite of the obligation under the Convention for all the States Parties to respect and ensure the rights to each child within their jurisdiction and without discrimination of any kind, children have often been deprived of the enjoyment of their basic rights, such as access to education, as a result of various forms of discrimination, not only on the grounds of their own circumstances, but also even on those of their parents or legal guardians.

At the level of the EU, the Swedish Presidency was marked by the high relevance given to the Rights of the Child in the adoption of the new multiannual programme of the European Council - the Stockholm Programme which defines EU work in the area of justice and home affairs for the period 2010-2014. The programme emphasises that the rights of the child concern all EU policies, and that they must be systematically and strategically taken into account with a view to ensuring an integrated approach.

Although, among the EU Member States, only Denmark and Greece have ratified the 2007 Council of Europe Convention against sexual abuse and sexual exploitation of children - an instrument signed by all but the Czech Republic, Hungary, Latvia and Malta - significant progress was made in a number of EU Member States in the protection of children's rights, sometimes in anticipation of the ratification of this convention.

\section{Immigration and detention}

The conditions of detention in centres for irregular migrants and asylum seekers were still a major source of concern in 2009. For instance, in June 2009 in Denmark a report concerning the living conditions of rejected asylum seekers contained a number of recommendations for improvement. Amnesty International released a statement concerning the treatment of immigrants detained under the Aliens Act in Finland, calling for detention to be a measure of last resort. Médecins Sans Frontières published a critical briefing paper in 2009 on the conditions in detention centres for undocumented migrants and asylum seekers in Malta, and the European Court of Human Rights found in two cases (at least one concerning an asylum applicant) that the conditions of detention in Greece amounted to degrading treatment in violation of Article 3 of the Convention (prohibition of torture and inhuman or degrading treatment or punishment). The number of children detained in such centres is rising in certain countries, as documented in a Dutch report published in 2009. Concerns over the detention of children were also highlighted in other countries. 


\section{Employment of irregular workers}

A number of developments took place in 2009 in this area at EU level. The Employers Sanctions Directive (2009/52/EC) provided for minimum standards on sanctions and measures against employers of illegally staying third-country nationals, and must be implemented by July 2011.Reports show various reasons why migrant workers (whether illegally staying or not) may find it difficult to challenge exploitative employment conditions. For one thing, the denunciation of employers of illegally-staying third-country nationals is made difficult because such illegally employed people risk being expelled from the national territory if they contact the authorities. They face the same difficulty if they seek to complain before courts about their employment conditions, even where they are formally allowed to do so.

Therefore the Member States should make full use of the possibilities offered under Article 13(4) of the Employers Sanctions Directive which obliges Member States to define the conditions under which they may grant temporary residence permits in a similar way as to that already done for victims of trafficking under Directive 2004/81. It is also essential that the Member States set up effective complaint mechanisms by which third-country nationals could lodge complaints directly or through designated third parties such as trade unions or other associations. In Belgium, NGOs have proposed that inspections with the aim of combating abuses concerning labour legislation would no longer lead to the relevant office of the Ministry of the Interior being notified of the presence of illegally-staying workers. This would follow the practice in Finland, where the Occupational Safety and Health authorities are not required to inform the police of abusive employment practices, including where victims are thirdcountry nationals working without a permit.

In Germany, there are examples of trade unions supporting irregular migrants by negotiating with employers without relying on courts and thus avoiding the risk that the worker will be expelled as a result of filing a complaint. In other countries it may be possible on the basis of existing legislation to grant exceptional residence permissions to aliens for collaborating with justice, as is done for victims of human trafficking.

\section{Common European Asylum System}

During 2008-2009 the Commission made a number of proposals regarding the establishment of the second phase of the Common European Asylum System, and related issues, in order to ensure better and more harmonised standards of protection. The amending the Eurodac Regulation proposal aims at ensuring a more efficient use of the Eurodac database and that data protection concerns are better addressed

The proposal amending the Dublin Regulation includes new rules on detention of persons under the Dublin procedure and a possibility of suspending transfers 
to a Member State in cases where that Member State is facing particular difficulties with regard to its reception capacities due to large numbers of asylum seekers, or when it does not comply with EU asylum standards as set out in the relevant instruments. The rules in relation to family members and unaccompanied minors are amended, to benefit the persons concerned.

The proposal amending the Reception Conditions Directive introduces new rules on detention, which draw on the UNHCR guidelines, and enhance standards as regards addressing the needs of vulnerable persons, access to employment, material support and health care. The proposals amending the Asylum Procedures and Qualifications Directives (October 2009) suggest among other things, a stronger wording as regards gender-based persecution, an approximation of rights between refugees and beneficiaries of subsidiary protection, the introduction of a general principle of automatic suspensive effect in line with developing case law and reducing the grounds on which an individual asylum interview can be omitted.

In May 2010 the Commission's proposal for a Regulation establishing a European Asylum Support Office (EASO) was formally adopted. The EASO will play a role in approximating Member States asylum practices and will be fully operational one year after the entry into force of the relevant Regulation.

.Regarding most of the above proposals, discussions in the European Parliament and the Council were ongoing during 2010. Overall, the Commission proposals can be welcomed from a fundamental rights perspective.

\section{Information society, respect for private life and protection of personal data}

The European Union, which has played a significant role in driving the development and introduction of national data protection laws in number of legal systems in the EU, continues to promote the development of international standards for personal data protection. This is one of the main goals set up by the Union in the Stockholm Programme adopted in December 2009. The programme calls for the introduction of a comprehensive protection scheme regarding privacy and personal data protection. In the past two years, the EU institutions and bodies launched various initiatives, the aim of which was to focus on specific issues on data protection, including rights awareness, the fight against cyber crime and social networking.

Several major legal developments have taken place at the national level within the last year or so, aimed primarily at incorporating basic principles of data protection into various laws (e.g. employment law, law on electronic communication networks, etc.). One of the most significant developments, however, occurred on the issue of data retention. In 2009, the European Court of Justice upheld the legal basis on which the Data Retention Directive was adopted. The European Commission launched infringement proceedings against 
several Member States who delayed the transposition of the Directive, and obtained favourable judgments from the ECJ against them. Furthermore, in the cases of Romania and Germany the Constitutional Court declared the national law transposing the Directive to be unconstitutional. A certain degree of discontent by civil society, as well as telecommunication companies and internet service providers about the effects of the data retention law, has been expressed in several countries. 


\section{Introduction}

\section{Implications of the Lisbon Treaty}

The entry into force of the Treaty of Lisbon at the end of 2009 has significantly strengthened the protection of fundamental rights at European level. In fact, the Treaty offers a set of innovations concerning better lawmaking, values and access to justice - all of which are of immediate relevance to fundamental rights.

Firstly, the new European Union (EU) treaties underline the value foundation of the Union. The EU Charter of Fundamental Rights has become legally binding. The Charter sets out in a single text, for the first time in the EU's history, the whole range of civil, political, economic and social rights of European citizens and all persons resident in the EU. It makes explicit that the Union "shall respect cultural, religious and linguistic diversity"1 and that any discrimination based on any ground such as sex, race, colour, ethnic or social origin, genetic features, language, religion or belief, political or any other opinion, membership of a national minority, property, birth, disability, age or sexual orientation" is prohibited. $^{2}$

Under the Lisbon Treaty, EU primary law makes, for the first time ever, reference to "persons belonging to minorities"3 and "membership of national minorit[ies]". 4 According to Article 2 of the revised Treaty of the European Union (TEU), the Union is "founded on the ... respect for human rights, including the rights of persons belonging to minorities". The Member States' representatives have thus also confirmed that the rights of persons belonging to minorities are values that "are common to the Member States in a society in which pluralism ... prevail[s]".5

This does not mean that the EU is equipped with a competence to legislate on "minority rights" in the stricter sense. Nor does the Treaty provide any definition of what a minority is. The new and rather prominent references can, however, be perceived as clearly indicating that EU primary law recognises that belonging to a minority is a relevant factor to the individual situation of human beings. The many different contexts of belonging to ethnic, linguistic, religious or any other sort of minority present specific challenges, and call for different

See Article 22 of the Charter of Fundamental Rights.

See Article 21 of the Charter of Fundamental Rights.

See Article 2 of the Treaty of the European Union (TEU) as amended by the Treaty of Lisbon.

See Article 21 of the Charter of Fundamental Rights

See Article 2 of the TEU as amended by the Treaty of Lisbon. 
legal and political responses, over some of which (but far from all) the EU has powers to act. ${ }^{6}$

The EU treaties also aim to provide an essential foundation for better lawmaking, particularly in the area of anti-discrimination, where the Union is set under a new horizontal obligation: "In defining and implementing its policies and activities, the Union shall aim to combat discrimination based on sex, racial or ethnic origin, religion or belief, disability, age or sexual orientation". ${ }^{7}$ This obligation applies without any exception with regard to EU law and it will therefore be important to constantly remind the EU institutions of this new explicit obligation. In addition, the Treaty of Lisbon calls on the EU institutions to "maintain an open, transparent and regular dialogue with representative associations and civil society". 8 The European Commission is thus explicitly tasked to "carry out broad consultations with parties concerned in order to ensure that the Union's actions are coherent and transparent".

The newly-introduced citizen initiative will add a new facet of participatory democracy alongside that of representative democracy at EU level. It may foster greater transnational debate about fundamental rights-related issues in Europe. In the future, one million citizens - less than a quarter of one per cent of all EU citizens - can invite the Commission to submit "any appropriate proposal on matters where citizens consider that a legal act of the Union is required for the purpose of implementing the Treaties". ${ }^{10}$

Better lawmaking would profit from the EU institutions making use of independent expert knowledge, especially when fundamental rights issues are at stake. In this context, it may be useful to remember that the European Council invited the EU institutions "to make full use of the expertise of the European Union Agency for Fundamental Rights and to consult, where appropriate, with the Agency, in line with its mandate, on the development of policies and legislation with implications for fundamental rights".

The new EU treaties substantially extend access to judicial protection. This implies that police and judicial cooperation in the area of criminal law - an area of most obvious relevance for the protection of fundamental rights - is now covered by the jurisdiction of the Court of Justice of the European Union, although this will not apply during the first five years of entry into force of the Lisbon Treaty. The common foreign and security policy remains beyond the Court ambit; however, the Court is granted jurisdiction for reviewing the

\footnotetext{
6 See European Parliament resolution on the protection of minorities and anti-discrimination policies in an enlarged Europe (2005/2008(INI)).

7 Art. 10 of the Treaty on the Functioning of the European Union (TFEU, replacing the former Treaty establishing the European Community (EC Treaty)).

8 Art. 11 Para 2 TEU.

9 Art. 11 Para. 3 TEU.

10 Art. 11 Para 4 TEU.

11 See European Commission (2009) The Stockholm Programme - An open and secure Europe serving and protecting the citizen, Brussels: European Commission, p. 12.
} 
legality of decisions of the Council providing for "restrictive measures against natural and legal persons". ${ }^{12}$ Moreover, a general clause establishes in primary law a sort of accelerated procedure before the Court if a preliminary procedure concerns "a person in custody" - in such cases the Court "shall act with a minimum of delay". ${ }^{13}$

The Lisbon Treaty also provides for the accession of the EU to the European Convention on Human Rights (ECHR). ${ }^{14}$ While the Union's system for the protection of fundamental rights is supplemented and enhanced by the incorporation of the Charter of Fundamental Rights into its primary law, as a result of acceding to the ECHR the Union will be integrated into its fundamental rights protection system, in addition to the internal protection of these rights by the case law of the Court of Justice, and will be submitted to the external control provided by the ECHR and by the European Court of Human Rights in Strasbourg. This will enhance consistency between the Strasbourg and the Luxembourg human rights systems,. Accession to the ECHR will afford citizens protection against the action of the Union similar to that which they already enjoy against action by all the Member States, thereby improving judicial protection of fundamental rights in Europe for the individuals. This is all the more worthwhile because the Member States have transferred substantial powers to the Union. The accession will also enhance the credibility of the Union in the eyes of third countries which it regularly calls upon in its bilateral reports to respect the ECHR..

\section{The outline of the Annual Report}

In the context of these recent and significant changes in the legal landscape of Europe, the Annual Report of the European Union Agency for Fundamental Rights (FRA) covers events and developments in the area of fundamental rights in the European Union for the year 2009.

The FRA Annual Report is based primarily on the research and data collection activities of the Agency. It draws on FRA's primary data collection, including the findings of the EU-MIDIS survey - the Agency's European Union Minorities and Discrimination Survey published in 2009. The survey interviewed 23,500 people with an ethnic minority background across the EU 27 Member States in 2008 and is the largest EU-wide survey of its kind on minorities' experiences of discrimination, racist victimisation and policing. The report also includes information provided by the Agency's two EU-wide information-gathering groups - the RAXEN group of National Focal Points (NFPs) and the FRALEX legal experts group. The RAXEN group provides material that falls under the general heading of racism, xenophobia and related intolerance, while the FRALEX group supplies more legal information under a broader range of topics of fundamental rights. In each Member State the

\footnotetext{
Art. 275 Para. 2 TFEU.

13 Art. 267 TFEU.

14 Art. 6 Para. 2 TEU.
} 
RAXEN or FRALEX groups collect data under common headings supplied by the Agency, in cooperation with various national organisations and actors, and in accordance with specific and common guidelines. National reports are produced for each Member State, and the data and information provided by these national reports is checked for accuracy by 27 liaison officers from the governments of each Member State. The national reports and resulting EU overviews provide the core of the material within the Annual Report.

During 2009-2010, the FRA has researched and published a number of reports on subjects that feed into the information given in this Annual Report. These include reports on discrimination on the grounds of sexual orientation, the experiences and awareness of victims of racial/ethnic discrimination, the housing conditions of Roma, the issue of ethnic profiling, the rights of the child, child trafficking, and the problems of separated and asylum-seeking children. In addition, in May 2010 the FRA issued a series of four reports on strengthening the fundamental rights architecture in the EU, focusing on national human rights institutions in the EU Member States ${ }^{15}$, data protection and the role of authorities in the field ${ }^{16}$, rights awareness and equality bodies ${ }^{17}$, as well as on the impact of the Racial Equality Directive ${ }^{18}$.

This year's FRA Annual Report is divided into nine chapters. Chapter 1 covers information on equality bodies and complaints mechanisms under the Racial Equality Directive, followed by an outline of developments in the area of racist violence and crime in Chapter 2. Chapter 3 focuses information on racism and discrimination in various areas of social life - employment, housing, education and healthcare - and then includes a more general section dealing with issues relating to migrants and minorities in other areas of social life. Chapter 4 looks at developments relevant to equality and anti-discrimination that have not already been covered in the preceding sections, including discrimination based on sex, disability, age and sexual orientation. The following chapters cover developments in 2009 which fall under the headings of the FRA's Multiannual Framework (MAF) - the document that sets out the thematic areas of the Agency's activities in line with the priorities of the European Union in the field of human rights over the coming years. Chapter 5 highlights developments in the field of the rights of the child and protection of children. Chapter 6 then examines issues related to the integration of immigrants, and visa and border control, followed by an analysis of developments in the field of access to justice and victim compensation in Chapter 7. Participation of citizens of the EU in the Union's democratic functioning is explored in Chapter 8, while an overview is

15 FRA (2010) National Human Rights Institutions in the EU Member State, Luxembourg: Office for Publications of the European Union.

16 FRA (2010) Data Protection in the European Union: the role of National Data Protection, Luxembourg: Office for Publications of the European Union.

17 FRA (2010) Rights Awareness and Equality Bodies, Data in Focus Report 3, Luxembourg: Office for Publications of the European Union.

18 FRA (2010) The Impact of the Racial Equality Directive: Views of Trade Unions and Employers in the European Union, Luxembourg: Office for Publications of the European Union. 
provided on the subject of the information society, respect for private life and the protection of personal data in Chapter 9.

Finally, a new feature of this year's Annual Report is the inclusion of an Annex indicating the current state of play regarding the acceptance by Member States of international human rights instruments, namely conventions of the United Nations and agreements of the Council of Europe. It is anticipated that this Annex will be included and updated in each subsequent FRA Annual Report.

Throughout this report there are references to examples of 'good practice'. The identification of examples of 'good practice' acknowledges the value of a practice and contributes to supporting a culture of continuous progress. However the identification as 'good practice' does not imply that the respective practice has been directly scrutinised in depth by the Agency. 


\section{Equality bodies and complaints mechanisms under the Racial Equality Directive}

The Racial Equality Directive ${ }^{19}$ is the most important piece of EU legislation combating discrimination or grounds of 'race' and ethnic origin. It was adopted in 2000, and prohibits discrimination in the areas of employment, education, social protection, including social security and healthcare, and in access to goods and services, including housing. This section provides an overview of the implementation of the Racial Equality Directive, with a particular focus on complaints mechanisms. Member States are under a legal obligation to ensure compliance with directives,$^{20}$ and in the case of the Racial Equality Directive, prominently to "designate a body or bodies for the promotion of equal treatment of all persons without discrimination on the grounds of racial or ethnic origin. ${ }^{21}$

While EU Member States are under an obligation to establish Equality Bodies in accordance with Article 13 of the Racial Equality Directive - something which, by the end of 2009, Poland still had not done and which Malta did not appear to have done in full - the degree of independence and the resources at the disposal of these bodies varies considerably across the EU. The Czech Republic only in 2009 passed legislation intended to comply with the Directive, with an equality body in place as of 1 December $2009 .^{22}$ In Luxembourg the equality body became operational only in late $2008^{23}$ and in Spain in early 2009.

The European Commission, being responsible for ensuring correct implementation of the Directive by Member States, has sent what is termed "reasoned opinions" to about two thirds of the Member States, and four additional formal notices, indicating that transposition of the Directive was unsatisfactory. (If the Commission after a period of negotiation is unable to press for correct transposition of the legislation at the national level voluntarily, it may ultimately resort to judicial proceedings before the Court of Justice of the European Union (through the Lisbon Treaty, previously the European Court of Justice $\left.(\mathrm{ECJ})^{24}\right)$.

\footnotetext{
19 Council Directive 2000/43/EC of 29 June 2000, implementing the principle of equal treatment on grounds of racial and ethnic origin (OJ L 180 of 19.07.2000).

Art. 249 para. 3 TEU.

21 Art. 13(1).

$<$ www.psp.cz/sqw/hlasy.sqw?G=50202\&o=5> (04.09.2009).

Law of 28 November 2006

24 (Art 228 TEU).
} 
A lack of adequate human and financial resources is a major problem for the equality body in a majority of countries, including Austria, Cyprus, Estonia, Germany, Hungary, Ireland, Italy, Latvia, Malta (where the Equality Body does not have jurisdiction to act in relation to racial discrimination in employment) ${ }^{25}$, Romania and the Slovak Republic. And the independence of some equality bodies, such as the Consiliul Național pentru Combaterea Discriminării [National Council on Combating Discrimination (NCCD)] in Romania, is a concern to a number of NGOs. In Ireland, the cut of 43 per cent in the budget of the Equality Authority which took effect in 2009 led to the resignation of the CEO of the Authority, and an alliance of non-governmental organisations, the Equality \& Rights Alliance (ERA) organised a campaign against the cuts, although its complaint to the European Commission to the effect that Ireland was in breach of European equality law ${ }^{26}$ was not upheld.

Some progress is however being made: in October 2009, the Court of Justice of the European Union closed infringement proceedings against Austria and Italy after national legislation had been changed. Problems in Austria had concerned the definition of harassment, lack of appropriate sanctions in cases of discriminatory dismissals, and failure to transpose rules on victimisation. Italy had problems with two of these aspects, harassment and victimisation, and in addition with the burden of proof.

The 2008 Feryn case remains the only one that the Court of Justice (then the ECJ) has delivered interpreting the Racial Equality Directive. ${ }^{27}$ The Court provided a broad interpretation of 'direct discrimination', ${ }^{28}$ so that it encompasses simply the publication of a discriminatory employment policy (an unwillingness to recruit an employee of a certain ethnic or racial origin) even in the absence of an identifiable complainant. ${ }^{29}$ In the language of the Court, such publication would be discriminatory if it 'declares publicly that it will not recruit employees of a certain ethnic or racial origin, something which is clearly likely to strongly dissuade certain candidates from submitting their candidature and, accordingly, to hinder their access to the labour market' (paragraph 25). ${ }^{30}$

25 In Malta, the Department of Industrial and Employment Relations (DIER), although not an equality body, is empowered by law to investigate, both ex officio and also on the basis of a complaint, alleged cases of discrimination in employment on a number of grounds, including race.

26 See

http://www.eracampaign.org/uploads/Letter $\% 20$ to $\% 20 \mathrm{Mr} \% 20$ Spidla $\% 20 \mathrm{re} \% 20$ Equality $\% 20$ Authority\%2024th\%20April.doc

27 Case C-54/07, judgment of 10 July 2008, available at: http://curia.europa.eu/jurisp/cgi-bin/form.pl?lang=EN\&Submit=rechercher\&numaff $=$ C-54/07 (see European Union Agency for Fundamental Rights (FRA) (2009) Annual Report 2009, Luxembourg: Publications Office of the European Union, p. 71).

28 The directive also covers indirect discrimination, although as yet there has been no case law on this.

29 In relation to Article 2(2)(a) of the directive.

30 The burden of proof was also reversed, see paragraphs 31 and 32 of the Court ruling. See, however, the appeal of the judgment of the Court of First Instance (now the General Court) of 


\subsection{The level of awareness}

The special Eurobarometer on Discrimination in the EU in 2009 reveals a number of concerns. Only a third of EU citizens believe they know their rights related to non-discrimination or harassment. This is consistent with the situation in the preceding year. The difference between the Member States is however quite varied, with knowledge of their rights ranging from 63 per cent to 16, with Finland, the UK, Sweden, and Malta at the top with more than 40 per cent awareness and Austria and Bulgaria at the bottom with 16 and 21 per cent respectively. ${ }^{31}$

Compared with the results from the corresponding Eurobarometer in 2008, some Member States have seen a marked increase in awareness while others a decrease. At the positive end of the scale, the UK, France, Sweden and Ireland have increases of 6-8 percentage points. Poland, Portugal, and Greece have a decrease from 2008 of 8-12 percentage points. ${ }^{32}$ There is a strong link between the level of education of the respondent and awareness of rights. ${ }^{33}$

Victims of discrimination or harassment, according to the Eurobarometer, are not especially keen on reporting this to equality bodies. A third of the respondents preferred reporting such incidents to the police authorities, while only one eighth $(13 \%)$ indicated a primary preference for reporting to a body for the promotion of equal treatment. ${ }^{34}$ However, it should be noted that in the case of harassment incidents it may be more logical for a victim to report them to the police.

Looking at the results by Member State the situation is indeed diverse, with almost three quarters (74\%) being willing to report to an equality body in Sweden and more than half the respondents in the Netherlands and Belgium (53 and 51 respectively). At the other end of the spectrum, with only a quarter or less, Spain, Malta, Italy, and Finland (18, 21, 25, and 25 per cent respectively). ${ }^{35}$

10 September 2008 (Case T-284/06 Gualtieri v Commission), Case C-485/08 P; and C-73/08, Opinion of Advocate General Scharpston, 25 June 2009, paragraph 45 and C-101/08, Opinion of Advocate General Trstenjak, 30 June 2009, paragraph 121.

31 Special Eurobarometer 317 (Novembre 2009) Discrimination in the EU in 2009, Brussels: TNS Opinion et Social, pp. 34-35, QE10.

32 Special Eurobarometer 317 (Novembre 2009) Discrimination in the EU in 2009 Brussels: TNS Opinion et Social, p. 36.

33 Special Eurobarometer 317 (Novembre 2009) Discrimination in the EU in 2009, Brussels: TNS Opinion et Social, p. 37.

34 Special Eurobarometer 317 (Novembre 2009) Discrimination in the EU in 2009, Brussels: TNS Opinion et Social, p. 38, QE15a.

35 Special Eurobarometer 317 (Novembre 2009) Discrimination in the EU in 2009, (Novembre 2009) p. 41, QE15. 
The FRA's EU-MIDIS report, ${ }^{36}$ launched on Human Rights Day, 10 December 2009, at the FRA Fundamental Rights Conference in Stockholm, shows that the awareness of equality bodies generally is lower among minority groups than in the population as a whole. According to EU-MIDIS, less than 10 per cent of particular minority groups have heard of the respective equality bodies in Luxembourg, Greece, Cyprus, and Slovenia (5, 5, 6, and 9 per cent respectively). However, in some Member States, particular minority groups have a relatively high level of awareness of equality bodies. The Netherlands, Estonia, Poland, Belgium, Czech Republic, and Sweden all show more than 50 per cent awareness $(71,65,59,58,58$, and 55 per cent respectively). The average level of unawareness of a named equality body (or bodies, as applicable) across the EU27 according to EU-MIDIS is 60 per cent (see Figure 1.1).

Figure 1.1 Ethnic minority/migrant respondents who have heard of at least one of up to three named equality bodies in their country, EU27 (\%) - EU-MIDIS results

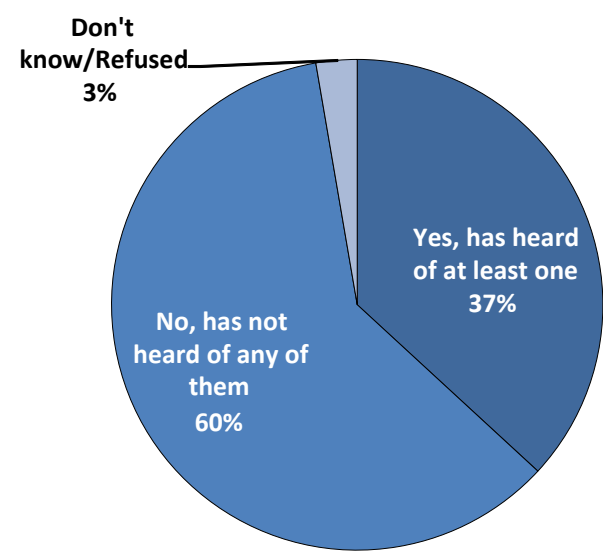

Source: FRA (2010) 'Rights Awareness and Equality Bodies', Data in Focus Report 3, Figure 8 (EU-MIDIS survey questions B2a-B2 $c^{37}$ )

The knowledge of any of the named equality bodies that would support discriminated persons among some minority groups is alarmingly low. In some EU Member States, the EU-MIDIS survey recorded levels exceeding 90 per cent of unawareness. The average level of unawareness across the EU27 is 80 per cent (see Figure 1.2).

FRA (2009) EU-MIDIS Main Results Report, Luxembourg: Publications Office of the European Union, available at: http://www.fra.europa.eu/fraWebsite/eumidis/eumidis_main_results_report_en.htm; see generally www.fra.europa.eu/eu-midis.

37 The survey questionnaire is available at: www.fra.europa.eu/eu-midis. 
Figure 1.2 Awareness of any organisation that can support people who have been discriminated against (\% of all respondents)

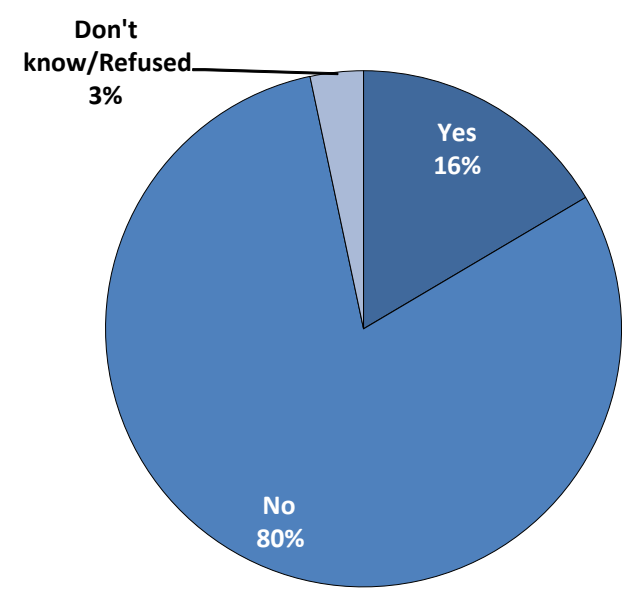

Source: FRA (2010) 'Rights Awareness and Equality Bodies', Data in Focus Report 3, Figure 7 (EU-MIDIS survey question A3)

The low awareness of where to complain is exacerbated by a feeling of disillusionment: almost two thirds of the respondents in the EU-MIDIS survey did not report discrimination due to a sense that nothing would happen or change by doing so (see Figure 1.3). 
Figure 1.3 Reasons for not reporting discrimination in nine $\operatorname{areas}^{38}(\%)$

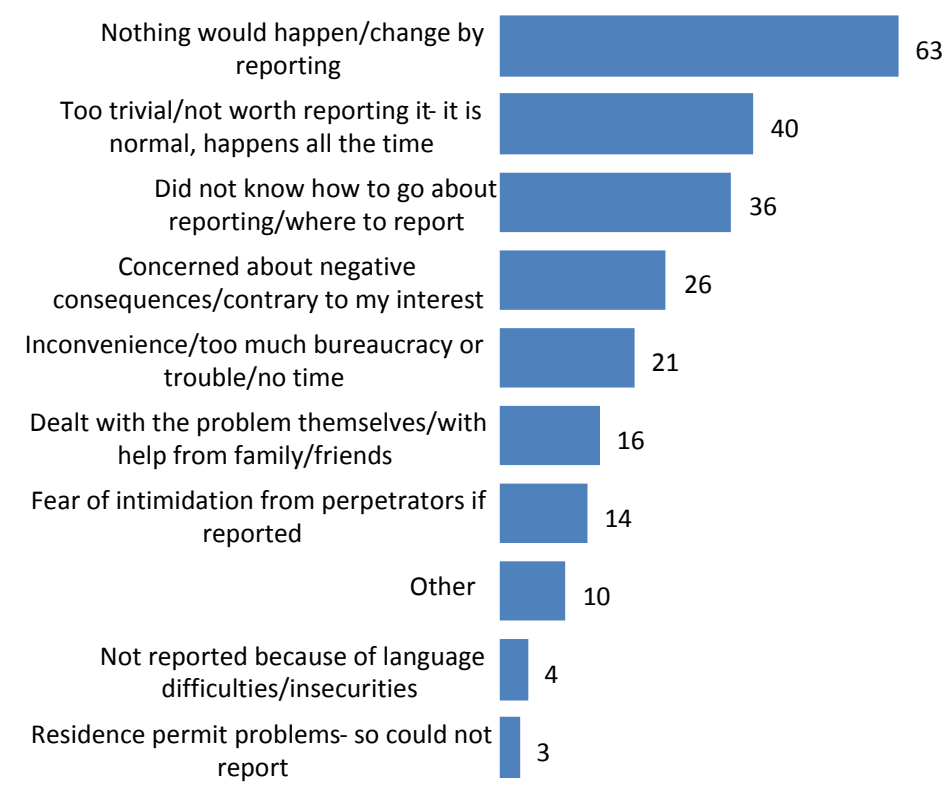

Source: FRA (2010) 'Rights Awareness and Equality Bodies', Data in Focus Report 3, Figure 12 (EU-MIDIS survey questions CA5-CI5)

In 2009 the FRA carried out a research project amongst the social partners of the EU to investigate their level of awareness of the Racial Equality Directive and the corresponding national legislation. ${ }^{39}$ More than 300 interviews were carried out with representatives of employers and trade unions in 27 Member States. The study found that awareness of the legislation was generally much higher, and evaluation of it more positive, in the older EU15 Member States than among the EU12 which joined after 2004 and that evaluations were generally more positive amongst trade unions than amongst employers. Knowledge of the equality bodies varied considerably among employers and trade unions. Whereas some collaborated strongly with their equality body, others had very little awareness of equality bodies, and some even saw them in some ways as a threat. Some respondents denied the existence of any problem of racism or ethnic discrimination relevant to their own sphere of work.

38 These nine areas fall under the themes of employment, education, housing, healthcare/social services and consumer services.

39 FRA (2010) The Impact of the Racial Equality Directive: Views of Trade Unions and Employers in the European Union, Luxembourg: Publications Office of the European Union. 


\subsection{Complaints data from equality bodies}

Article 13(2) of the Racial Equality Directive requires Member States to ensure that equality bodies have a mandate including "providing independent assistance to victims of discrimination in pursuing their complaints about discrimination". Complaints statistics have been collected by the RAXEN National Focal Points of the FRA during 2009, a majority being the annual numbers for 2008, but some also inclusive of data up until October 2009. ${ }^{40}$ The data provided are not easily comparable given the varied nature of the equality bodies. As noted in previous Annual Reports, a higher level of registered complaints is not necessarily a sign of high levels of discrimination. On the contrary, given the extent of subjectively experienced discrimination in all Member States, as noted in the EU-MIDIS survey, a higher number of complaints rather reflects that awareness is higher and that there is an efficient and credible mechanism in place. ${ }^{41}$ In almost all Member States, the number of officially registered complaints is remarkably low, ranging from virtually none, through a few dozens or hundreds. There are exceptions such as France (Haute autorité de lutte contre les discriminations et pour l'égalité (HALDE)) which registered some 10,500 cases in 2009. ${ }^{42}$ Other Member States with equality bodies receiving more than a few hundred complaints include Belgium, Ireland, and Sweden. An approximate EU average would be around 350 complaints.

According to complaint statistics, ${ }^{43}$ there is an increase in complaints based on ethnic discrimination in several Member States: Austria, Belgium, Bulgaria, Cyprus, France, Germany, Greece, and the Equality Commission for Northern Ireland, in the UK. In none of the 27 Member States however are the changes more dramatic than the 25 per cent increase noted by the HALDE, France.

In Sweden a new equality body was established which makes any trend in the number of complaints very difficult to identify, but the new equality body is receiving a relatively high number of complaints. ${ }^{44}$ Denmark also saw a revision of its complaints mechanism in 2009, with a new entity being given the mandate under the directive. The case is similar for the United Kingdom, where the Equality and Human Rights Commission (EHRC) took over the responsibilities for issues of racial discrimination from the then equality body, the Commission for Racial Equality, at the end of 2007. Therefore, any changes in the numbers of cases are not particularly meaningful, also for reasons of the very low numbers involved. Equality bodies in other Member States similarly

40 Comparisons between available data from the Member States also show the great need for accurate and comparative data delivered timely to the public.

41 See generally www.fra.europa.eu/eu-midis.

42 See HALDE (2009) Rapport annuel 2009, Paris: HALDE, available at: http://halde.fr/rapportannuel/2009/.

${ }^{43}$ As collected by the RAXEN NFPs during 2009

44 As indicated in the half year report by the Equality Ombudsman www.do.se. 
deal with so few cases (less than 20) that trends are not easily discernible, such as Estonia, Luxembourg, Malta, Portugal, Romania, Slovakia, and Slovenia.

Equality bodies in yet other Member States show a minor decrease in complaints, such as Finland, Hungary, Italy, Latvia, Lithuania, and the Netherlands. But given the relatively low number of cases, the change is probably not indicative of any major trend.

The Agency's EU-MIDIS survey shows that among the members of minority groups surveyed, an average of 30 per cent (ranging from 3 to 64 per cent) felt they had experienced discrimination during the last 12 months. ${ }^{45}$ Based on the extent of perceived discrimination, the number of complaints ought to be much higher.

45 FRA (2009) EU-MIDIS Main Results Report, Luxembourg: Publications Office of the European Union, p. 36, Figure 2.1, available at: www.fra.europa.eu/eu-midis. 


\section{Racist violence and crime}

\subsection{Effective means to assess the extent and nature of the problem}

Across the EU the collection and public availability of official criminal justice data on racist crime continues to vary significantly between Member States, with some publishing no data and only a select few collecting and publishing comprehensive data on a regular basis (Finland, Sweden and the UK).

The persistent gap in criminal justice data collection on racist crime in the majority of Member States is one of the reasons why the FRA carried out the EU-MIDIS survey mentioned in Chapter 1. This is the first EU-wide survey to collect comparable data on the experiences of racist crime of a sample of 23,500 people from selected ethnic minority and immigrant groups, the findings of which were published in 2009. The survey's results, which are based on a random sample, highlight the extent to which official data only shows the 'tip of the iceberg' when it comes to the real extent of unreported and unrecorded racist crime. The survey also presents detailed findings about the nature of these crimes.

This chapter briefly reports on publicly available data on racist crime with respect to trends, limited to a minority of Member States that collect sufficient data for analysis, and contrasts this information with some key results from EUMIDIS.

\subsection{Overall trends in officially recorded racist crime}

Table 2.1 indicates trends in criminal justice data on racist crime, ${ }^{46}$ which are based on the most recent publicly available government data. When looking at official criminal justice data on racist crime, direct comparisons should not be made between data gathered in different Member States. This is because information is reported and recorded differently in each country. However, looking at fluctuations in recorded crime within a Member State can serve to highlight patterns in both manifestations of racist crime and changes in recording practices (while acknowledging that Member States with low absolute figures tend to show the most significant percentage changes from year to year). With this in mind, Table 2.1 shows the following:

46 Encompassing a range of incidents and crimes, which variously cover racism, xenophobia, anti-Semitism and related crimes such as incitement to racial hatred and violence. 
- During the period 2000-2008, 10 of the 12 Member States which publish sufficient criminal justice data on racist crime to be able to undertake an analysis of trends, experienced an upward trend in recorded racist crime. The Czech Republic experienced a downward trend, and Poland's overall trend remained constant for the period for which data is available.

- Looking only at the most recent year for which data is available - 2007$2008^{47}-9$ of the 12 Member States which collect sufficient criminal justice data on racist crime experienced an upward trend in recorded racist crime, while 3 experienced a downward trend. In the UK the picture was divided, as England and Wales recorded a downward trend and Scotland a slight upward trend; therefore, the trend for the UK as a whole is decreasing (taking into account the relative population sizes of the jurisdictions for England and Wales, and Scotland).

47 In the case of Poland, this is 2006-2007.

48 For Northern Ireland, the figures over time were incomplete and did not allow a trend analysis to be calculated. 
Table 2.1 : Trends in officially recorded racist crime

\begin{tabular}{|c|c|c|c|c|c|c|c|c|c|c|c|}
\hline & 2000 & 2001 & 2002 & 2003 & 2004 & 2005 & 2006 & 2007 & 2008 & $\begin{array}{l}\% \text { change } \\
2007-2008\end{array}$ & $\begin{array}{c}\% \\
\text { change } \\
2000- \\
2008\end{array}$ \\
\hline Belgium & $\begin{array}{c}757 \\
\text { crimes }\end{array}$ & 751 & 727 & 848 & 1021 & 1224 & 1359 & 1310 & 1147 & $-12.4 \%$ & $+6.0 \%$ \\
\hline $\begin{array}{l}\text { Czech } \\
\text { Republic }\end{array}$ & $\begin{array}{c}364 \\
\text { crimes }\end{array}$ & 452 & 473 & 335 & 364 & 253 & 248 & 196 & 217 & $+10.7 \%$ & $-4.3 \%$ \\
\hline Denmark & $\begin{array}{c}28 \\
\text { incidents }\end{array}$ & 116 & 68 & 53 & 37 & 87 & 96 & 35 & $175^{* *}$ & $+400.0 \%$ & $+87.8 \%$ \\
\hline Germany & - & $\begin{array}{l}14,725 \\
\text { crimes }\end{array}$ & 12,933 & 11,576 & 12,553 & 15,914 & 18,142 & 17,607 & 20,422 & $+16.0 \%$ & $\begin{array}{c}+5.7 \% \\
(2001- \\
2008) \\
\end{array}$ \\
\hline France & $\begin{array}{c}903 \\
\text { reports }\end{array}$ & 424 & 1317 & 833 & 1574 & 979 & 923 & 723 & 864 & $+19.5 \%$ & $+20.5 \%$ \\
\hline Ireland & $\begin{array}{c}72 \\
\text { reports }\end{array}$ & 42 & 100 & 62 & 84 & 94 & 173 & 214 & 172 & -19.6 & $+24.2 \%$ \\
\hline Austria & $\begin{array}{c}450 \\
\text { complaints }\end{array}$ & 528 & 465 & 436 & 322 & 406 & 419 & 752 & 835 & $+11.0 \%$ & $+11.6 \%$ \\
\hline Poland & $\begin{array}{c}215 \\
\text { crimes }\end{array}$ & 103 & 94 & 111 & 113 & 172 & 150 & 154 & $-*$ & $\begin{array}{l}+2.7 \% \\
(2006- \\
2007) \\
\end{array}$ & $\begin{array}{c}+0.2 \% \\
(2000- \\
2007) \\
\end{array}$ \\
\hline Slovakia & $\begin{array}{c}35 \\
\text { crimes }\end{array}$ & 40 & 109 & 119 & 79 & 121 & 188 & 155 & 213 & $+37.4 \%$ & $+36.3 \%$ \\
\hline Finland & $\begin{array}{c}495 \\
\text { crimes }\end{array}$ & 448 & 364 & 522 & 558 & 669 & 748 & 698 & $1,163 * *$ & $+66.6 \%$ & $+14.2 \%$ \\
\hline Sweden & $\begin{array}{c}2,703 \\
\text { crimes }\end{array}$ & 2,785 & 2,391 & 2,436 & 2,414 & 2,383 & 2,575 & 2,813 & $4,826 * * *$ & $+71.6 \%$ & $+9.7 \%$ \\
\hline $\begin{array}{l}\text { England } \\
\text { and } \\
\text { Wales } \\
\text { Scotland }\end{array}$ & $\begin{array}{c}47,701 \\
\text { incidents } \\
\text { Offences }\end{array}$ & 53,121 & $\begin{array}{r}54,858 \\
1,699\end{array}$ & $\begin{array}{l}49,344 \\
2,673\end{array}$ & $\begin{array}{r}54,157 \\
3,097\end{array}$ & $\begin{array}{r}57,863 \\
3,856\end{array}$ & $\begin{array}{l}60,651 \\
4,294\end{array}$ & $\begin{array}{l}61,262 \\
4,474\end{array}$ & $\begin{array}{r}57,055 \\
4,543\end{array}$ & $\begin{array}{l}-6.9 \% \\
+1.5 \%\end{array}$ & $\begin{array}{c}+2.5 \% \\
\\
+19.1 \% \\
(2002- \\
2008)\end{array}$ \\
\hline
\end{tabular}

Notes: * Not available. ** Not comparable with previous years due to changes in the incident counting rules. *** Not comparable with previous years due to changes in the definition of hate crimes.

In sum, looking at overall long-term trends in recorded racist crime from 2000 to 2008 , and between the last two years for which statistics are available, the picture emerges of a general increase in those 12 Member States where sufficient data is available for analysis. However, changes in 2008 to data collection practices in Sweden ${ }^{49}$ and Finland ${ }^{50}$ limits the comparability of internal generated data from previous years for these two countries, and hence any interpretation of a trend has to be treated with caution. For this reason it is

492008 - change in the definition of 'hate crime'.

502008 - not comparable with previous years due to changes in the incident counting system. 
preferable to focus on long-term trends. At the same time, the significant increases between 2007 and 2008 in recorded figures for Sweden and Finland are most likely an indicator that these changes signify improvements in data collection on racist crime. Put simply: high racist crime figures are not only a negative indicator of an existing problem with racist crime in a Member State, but are also a positive indicator that Member States are responding seriously to the problem of racist crime.

\subsection{Trends in anti-Semitism}

Only six Member States collect sufficiently robust criminal justice data that allows a comparison of trends in anti-Semitic crime. ${ }^{51}$

Table 2.2: Trends in recorded anti-Semitic crime ${ }^{52}$

\begin{tabular}{|l|c|c|c|c|c|c|c|c|c|c|}
\hline & 2001 & 2002 & 2003 & 2004 & 2005 & 2006 & 2007 & 2008 & $\begin{array}{c}\% \text { change change } \\
2007-2008\end{array}$ & $\begin{array}{c}\% \\
2001- \\
2008\end{array}$ \\
\hline Austria & 3 & 20 & 9 & 17 & 8 & 8 & 15 & 23 & $+53.3 \%$ & $+98.3 \%$ \\
\hline France & 219 & 936 & 601 & 974 & 508 & 571 & 402 & 397 & $-1.2 \%$ & $+41.1 \%$ \\
\hline Germany & 1,629 & 1,594 & 1,226 & 1,346 & 1,682 & 1,662 & 1,561 & 1,496 & $-4.2 \%$ & $-0.3 \%$ \\
\hline Netherlands* & 41 & 60 & 50 & 58 & 65 & 108 & 50 & 49 & $-2.0 \%$ & $+9.7 \%$ \\
\hline Sweden & 115 & 131 & 128 & 151 & 111 & 134 & 118 & 159 & $+34.7 \%$ & $+6.7 \%$ \\
\hline UK & 310 & 350 & 375 & 532 & 455 & 594 & 561 & 541 & $-3.6 \%$ & $+9.8 \%$ \\
\hline
\end{tabular}

Notes: * Statistics of the Dutch Public Prosecution Service: number of discriminatory incidents where anti-Semitism was identified.

Looking at Table 2.2, the picture of anti-Semitic crime that emerges is as follows: between 2001 and 2008 five Member States experienced an overall upward trend, while between 2007-2008 a mixed picture emerges as two countries showed an upward trend and four a downward one. In the case of Austria, the recorded figures are consistently low each year, and therefore the

51 Note: the UK data is from the 'Community Security Trust', an independent Jewish organisation, but is referred to by official government sources in the UK.

52 In addition to the Member States listed here, the Centre for Equal Opportunities and Racism (CEOOR) in Belgium also releases official statistics on complaints of anti-Semitism, but these statistics go beyond addressing just racist crime. For details please see Anti-Semitism. Summary overview of the situation in the European Union 2001-2008. FRA 2009. 
notable 53.3\% increase between 2007 and 2008, which reflects an increase of only eight crimes, has to be put in perspective; particularly as this recent increase impacts significantly on the overall trend in recorded crime for Austria between 2001 and 2008 .

\subsection{Trends in right-wing extremism}

Only four Member States collect sufficiently robust criminal justice data that allows for a comparison of trends in crime with an extremist right-wing motive.

Table 2.3: Trends in recorded crime with an extremist right-wing motive

\begin{tabular}{|l|c|c|c|c|c|c|c|c|c|c|c|}
\hline & 2000 & 2001 & 2002 & 2003 & 2004 & 2005 & 2006 & 2007 & 2008 & $\begin{array}{c}\% \text { change } \\
2007-2008\end{array}$ & $\begin{array}{c}\% \text { change } \\
2000-2008\end{array}$ \\
\hline Austria & 291 & 301 & 261 & 264 & 189 & 188 & 204 & 280 & 333 & $+18.9 \%$ & $+3.4 \%$ \\
\hline Germany & - & 10,054 & 10,902 & 10,792 & 12,051 & 15,361 & 17,597 & 17,176 & 19894 & $+15.8 \%$ & $\begin{array}{c}+10.6 \% \\
(\mathbf{2 0 0 1 - 2 0 0 8})\end{array}$ \\
\hline France & 207 & 198 & 179 & 148 & 461 & 419 & 301 & 247 & -53 & $\begin{array}{c}-17.9 \% \\
(2006-2007)\end{array}$ & $\begin{array}{c}+17.9 \% \\
(2000-2007)\end{array}$ \\
\hline Sweden & 566 & 392 & 324 & 448 & 306 & 292 & 272 & 387 & 667 & $+72.4 \%$ & $+\mathbf{+ 7 . 7 \%}$ \\
\hline
\end{tabular}

Looking at Table 2.3, a consistent pattern of increases in recorded crime with an extremist right-wing motive can be noted over both the long and short-term period, with the exception of France. These increases can reflect both an actual rise in the activities of right-wing extremists, as well as improvements in the detection and prosecution of these activities by criminal justice agencies in these four Member States, particularly with regard to internet-based crime.

\footnotetext{
${ }^{53}$ This figure has not been reported in the latest publication by the French National Consultative Commission on Human Rights (La lutte contre le racisme et la xénophobie - 2008), and the French system of recording these crimes has been undergoing a process of revision. However, the report does indicate that there have been 37 cases of violent crime and 111 threats with extreme right-wing characteristics. The same report also states that there has been a $16 \%$ increase in right-wing extremist crime between 2007 and 2008.
} 


\subsection{EU-MIDIS: filling a gap in current knowledge}

As described in Chapter 1, the full results report from the FRA EU-MIDIS survey was released in December 2009. ${ }^{54}$ The report presents detailed findings from 23,500 interviews with selected ethnic minority and immigrant groups, including respondents' experiences of racially motivated crime and detailed information about their most recent experiences of assault, threat and serious harassment.

The report's findings are in contrast with the persistent absence or 'undercount' by criminal justice data collection mechanisms of racist crime in the majority of EU Member States; for example:

- 18 per cent of all Roma interviewees and 18 per cent of all Sub-Saharan African interviewees indicated that they had experienced at least one incident of assault, threat or serious harassment in the last 12 months that they considered to be racially motivated. Other groups surveyed who considered they were victims of racially motivated assault, threat or serious harassment in the last 12 months were North Africans, Turkish, Central and East Europeans, Russians and former Yugoslavians, although the percentages among these groups indicating racist victimisation were less than 10 per cent.

- Findings for specific groups in Member States indicate that more than one in four respondents from the following groups considered that they were a victim of 'racially motivated' assault, threat or serious harassment in the last 12 months: Roma in the Czech Republic (32\%); Somalis in Finland (32\%); Somalis in Denmark (31\%); Africans in Malta (29\%), and (equally) 26\% of Roma in Greece, Roma in Poland and Sub-Saharan Africans in Ireland.

- Looking only at results for those who said they were victims of assault or threat in the last 12 months (excluding serious harassment) - 73 per cent of Roma victims and 70 per cent of Sub-Saharan African victims considered that the perpetrators of the last incident they experienced targeted them because of their immigrant or ethnic minority background. This increases to 81 per cent of Roma and 81 per cent of Sub-Saharan Africans if results for assault, threat and serious harassment are looked at together (the figure being 67 per cent for Turkish respondents and 61 per cent for North Africans).

54 FRA (2009) EU-MIDIS Main Results Report, Luxembourg: Publications Office of the European Union, available at: http://fra.europa.eu/fraWebsite/home/pub_eu-midis_en.htm. 
Part 4.3 in the EU-MIDIS Main Results Report ${ }^{55}$ compares results between the European Crime and Safety Survey (on the majority population in selected EU countries) and EU-MIDIS concerning a range of different crimes that allow for comparison; the findings indicate that minorities are victims of assault or threat on average more often than the majority population.

Table 2.4: Assault or threat, incident details (EU-MIDIS) (\%)

\begin{tabular}{|c|c|c|c|c|c|c|c|}
\hline & $\begin{array}{c}\text { Sub- } \\
\text { Saharan } \\
\text { African }\end{array}$ & CEE & $\begin{array}{c}\text { Ex- } \\
\text { Yugoslav }\end{array}$ & $\begin{array}{l}\text { North } \\
\text { African }\end{array}$ & Roma & Russian & Turkish \\
\hline & $\%$ & $\%$ & $\%$ & $\%$ & $\%$ & $\%$ & $\%$ \\
\hline \multicolumn{8}{|l|}{$\begin{array}{l}\text { Rate of victimisation (DD1, } \\
\text { DD2) }\end{array}$} \\
\hline Not victimised & 83 & 92 & 93 & 84 & 82 & 92 & 91 \\
\hline Victimised past 12 months & 9 & 4 & 3 & 9 & 10 & 4 & 3 \\
\hline Victimised past $2-5$ years & 8 & 4 & 4 & 7 & 8 & 4 & 5 \\
\hline \multicolumn{8}{|l|}{$\begin{array}{l}\text { Attributed racial/ethnic } \\
\text { motivation (DD4) }\end{array}$} \\
\hline $\begin{array}{l}\text { Yes, including the most } \\
\text { recent }\end{array}$ & 70 & 46 & 32 & 46 & 73 & 42 & 60 \\
\hline $\begin{array}{l}\text { Yes, but not including the } \\
\text { most recent }\end{array}$ & 2 & 5 & 4 & 10 & 5 & 1 & 5 \\
\hline No & 21 & 39 & 55 & 39 & 18 & 42 & 30 \\
\hline Don't know/no opinion & 6 & 9 & 9 & 5 & 4 & 14 & 6 \\
\hline \multicolumn{8}{|l|}{$\begin{array}{l}\text { Racist or religiously offensive } \\
\text { language used (DD9) }\end{array}$} \\
\hline Yes & 60 & 23 & 36 & 43 & 54 & 27 & 52 \\
\hline \multicolumn{8}{|l|}{ Perpetrators (DD8) } \\
\hline $\begin{array}{l}\text { From the same ethnic } \\
\text { group }\end{array}$ & 12 & 12 & 22 & 22 & 33 & 18 & 17 \\
\hline $\begin{array}{l}\text { From another ethnic } \\
\text { group }\end{array}$ & 19 & 27 & 32 & 31 & 12 & 16 & 31 \\
\hline From majority & 71 & 57 & 32 & 56 & 60 & 59 & 52 \\
\hline \multicolumn{8}{|l|}{ Perpetrators included (DD7) } \\
\hline $\begin{array}{l}\text { Member of your } \\
\text { household (incl. former) }\end{array}$ & 5 & 2 & 5 & 5 & 6 & 16 & 6 \\
\hline $\begin{array}{l}\text { Someone from your } \\
\text { neighbourhood }\end{array}$ & 17 & 12 & 23 & 15 & 27 & 11 & 17 \\
\hline $\begin{array}{l}\text { Someone you work } \\
\text { with/colleague }\end{array}$ & 4 & 4 & 7 & 6 & 3 & 7 & 6 \\
\hline
\end{tabular}

55 See http://fra.europa.eu/fraWebsite/attachments/eumidis_mainreport_conferenceedition_en_pdf 


\begin{tabular}{|c|c|c|c|c|c|c|c|}
\hline $\begin{array}{l}\text { A customer, client or } \\
\text { patient }\end{array}$ & 5 & 4 & 7 & 4 & 2 & 10 & 10 \\
\hline Someone else you know & 10 & 7 & 12 & 10 & 19 & 15 & 14 \\
\hline $\begin{array}{l}\text { Member of a right- } \\
\text { wing/racist gang }\end{array}$ & 8 & 6 & 5 & 6 & 12 & 1 & 13 \\
\hline Police officer & 3 & 1 & 4 & 4 & 4 & 7 & 7 \\
\hline Other public official & 2 & 2 & 2 & 2 & 2 & 1 & 2 \\
\hline $\begin{array}{l}\text { A stranger (someone else } \\
\text { you didn't know) }\end{array}$ & 58 & 66 & 44 & 52 & 52 & 59 & 43 \\
\hline
\end{tabular}

Source: EU-MIDIS, 2009

Table 2.4, which extracts data from the EU-MIDIS Main Results Report, presents a breakdown of results in consideration of survey respondents by 'aggregate groups' (for example, all Roma or all Sub-Saharan Africans) who indicated they were a victim of assault or threat (excluding serious harassment) in the last 12 months and the last 5 years (ranging from 3 per cent (Turkish and former Yugoslavians) to 10 per cent (Roma) among different aggregate groups in last 12 months). Victims were then asked whether they considered the most recent incident or any other incident in the past 12 months to be racially motivated (ranging from 32 per cent of former Yugoslavians to 73 per cent among the Roma (in consideration of the latest incident)). This information was further corroborated by a question asking whether racist or religiously offensive language was used in relation to the latest incident (ranging from 23 per cent of Central and East European respondents to 60 per cent of Sub-Saharan Africans).

Further detail was also collected about 'who' the perpetrator or perpetrators were in relation to the last incident in the previous 12 months. For example, many incidents of assault or threat were committed by strangers and members of the majority population. However, if the combined results for a range of perpetrator groups are looked at together, it is apparent that victimisation by people who are known either by sight or through some other form of acquaintance is also common, such as someone from the neighbourhood, a customer, or a work colleague. In comparison, members of right-wing racist gangs were identified as perpetrators in only a limited number of incidents. The 'top three' percentage of victim groups indicating that right-wing racist gangs were perpetrators was: 13 per cent of Turkish victims, 12 per cent of Roma victims, and 8 per cent of Sub-Saharan Africans. These results indicate that incidents of racist crime are not only the preserve of 'stranger danger' or rightwing extremism, and therefore would support efforts to tackle racism as it manifests itself in 'everyday' situations. 
In 2009, in the UK two BBC reporters of South Asian origin lived for eight weeks on a housing estate in Bristol, posing as a Muslim married couple. They recorded themselves being racially abused more than 50 times, with incidents including muttered insults, verbal abuse, being pelted with stones and glass, and one physical assault on the man. Most of the abuse came from young children and teenagers. While the reaction to the 'husband' from local people was unpredictable, the 'wife', who wore a headscarf, reported that she was "bullied and abused just about every time I stepped outside the door". ${ }^{56}$

Of particular concern from the EU-MIDIS study is the finding that perpetrators of assaults or threats were also identified as police officers and other public officials by 9 per cent of Turkish, 8 per cent of Russian, and 6 per cent (each) of Roma, North African and former Yugoslavian victims. These findings indicate that efforts to tackle sources of racism also need to address the potential role of State employees, such as the police, who are supposed to uphold the law and provide a public service for increasingly diverse European societies.

With this in mind, EU-MIDIS results showed that for the different aggregate groups surveyed, between 57 per cent and 74 per cent of incidents of assault or threat were not reported to the police. At the same time, between 60 per cent and 75 per cent of these incidents were regarded by different aggregate groups as 'serious'. Table 2.5 indicates that the main reason given by victims for not reporting their last experience of assault or threat was their lack of confidence in the police. This was followed by the response that the incident was too trivial or not worth reporting, which, given that the majority of victims also considered incidents of assault or threat to be serious, would seem to indicate the 'everyday' nature of incidents that are serious for victims.

\footnotetext{
${ }^{56}$ http://www.guardian.co.uk/uk/2009/oct/19/bbc-panorama-racism-bristol-report.
} 
Table2. 5: Reasons for non-reporting (EU-MIDIS) (\%)

\begin{tabular}{|c|c|c|c|c|c|c|c|}
\hline & $\begin{array}{c}\text { Sub- } \\
\text { Saharan } \\
\text { African }\end{array}$ & CEE & $\begin{array}{c}\text { Ex- } \\
\text { Yugosl } \\
\text { av }\end{array}$ & $\begin{array}{c}\text { North } \\
\text { African }\end{array}$ & $\begin{array}{c}\text { Rom } \\
\text { a }\end{array}$ & $\begin{array}{l}\text { Russi } \\
\text { an }\end{array}$ & $\begin{array}{c}\text { Turkis } \\
\mathbf{h}\end{array}$ \\
\hline & $\%$ & $\%$ & $\%$ & $\%$ & $\%$ & $\%$ & $\%$ \\
\hline \multicolumn{8}{|l|}{$\begin{array}{l}\text { Reasons for not reporting } \\
\text { (DD13) }\end{array}$} \\
\hline $\begin{array}{l}\text { No confidence in the } \\
\text { police }\end{array}$ & 47 & 33 & 55 & 34 & 75 & 41 & 52 \\
\hline $\begin{array}{l}\text { Too trivial/not worth } \\
\text { reporting }\end{array}$ & 24 & 25 & 41 & 22 & 27 & 24 & 44 \\
\hline $\begin{array}{l}\text { Dealt with the problem } \\
\text { themselves }\end{array}$ & 17 & 15 & 32 & 18 & 40 & 37 & 30 \\
\hline $\begin{array}{l}\text { Concerned about negative } \\
\text { consequences }\end{array}$ & 12 & 11 & 22 & 7 & 38 & 12 & 31 \\
\hline $\begin{array}{l}\text { Inconvenience/too much } \\
\text { trouble/time }\end{array}$ & 13 & 16 & 16 & 10 & 11 & 18 & 31 \\
\hline $\begin{array}{l}\text { Fear of intimidation from } \\
\text { perpetrators }\end{array}$ & 9 & 6 & 12 & 8 & 35 & 10 & 19 \\
\hline Negative attitude to police & 7 & 5 & 4 & 9 & 33 & 18 & 24 \\
\hline $\begin{array}{l}\text { Language } \\
\text { difficulties/insecurities }\end{array}$ & 6 & 4 & 2 & 3 & 1 & 9 & 5 \\
\hline Reported elsewhere & 4 & 2 & 0 & 2 & 1 & 0 & 0 \\
\hline $\begin{array}{l}\text { Residence permit } \\
\text { problems }\end{array}$ & 0 & 4 & 2 & 5 & 0 & 0 & 0 \\
\hline Other reason & 15 & 13 & 4 & 12 & 16 & 12 & 10 \\
\hline
\end{tabular}

In addition to data on assault and threat, EU-MIDIS also collected detailed information on experiences of serious harassment. The percentage of all survey respondents experiencing serious harassment was greater than for assault or threat; with between 53 per cent and 79 per cent of victims indicating that they considered their most recent experience in the last 12 months to be racially motivated (the EU-MIDIS Main Results Report provides detailed findings).

\subsection{Encouraging developments?}

By 28 November 2010, Member States should have implemented Council Framework Decision 2008/913/JHA on combating certain forms and expressions of racism and xenophobia by means of criminal law, and by 28 November 2013 the first assessment of its implementation will have been undertaken. In the run up to the implementation of the Framework Decision, encouraging developments can be noted in some Member States that have taken measures designed to give effect to this legislation at the national level; for example, the Czech Republic, ${ }^{57}$ Denmark, ${ }^{58}$ Malta $^{59}$ and Slovakia. ${ }^{60}$

\footnotetext{
57 Czech Republic/Zákon č. 40/2009 Sb., o trestní zákon [Act No. 40/2009 Coll., Criminal Code], available at HYPERLINK

"http://www.lexdata.cz/lexdata/sb free.nsf/c12571cc00341df10000000000000000/c12571cc0
} 
Given these developments, one might expect to see some improvement in data collection on racist crimes that can serve to monitor application of this law in practice. Against this expectation, in late December 2008 Ireland's National Consultative Committee on Racism and Interculturalism (NCCRI), which was the key voluntary mechanism for monitoring racist crime, preparing bi-annual reports on racist incidents, was closed due to budget cuts. As a result, Ireland has lost one of its core data collection mechanisms on racist crime. In contrast, amendments to how data on racist and hate crime is recorded in Finland and Sweden have served to further enhance these countries' continued good practices.

The continued absence or limited nature of criminal justice data on racist crime in many Member States shows that much still needs to be done to address the gap between legislation, criminal justice data, and the reality of everyday experiences of racist crime. In 2010, with a view to the forthcoming implementation of Framework Decision 2008/913/JHA, the Agency is undertaking a thorough mapping of existing criminal justice and civil society data collection on racist crime and other hate crimes in the EU, the results of which will be published in due course.

0341df1c1257556003df675?OpenDocument"http://www.lexdata.cz/lexdata/sb free.nsf/c1257 $1 \mathrm{cc} 00341 \mathrm{df} 10000000000000000 / \mathrm{c} 12571 \mathrm{cc} 00341 \mathrm{df} 1 \mathrm{c} 1257556003 \mathrm{df} 675$ ? OpenDocument $(\mathrm{C}$ zech only, accessed on 12.10. 2009). The new Criminal Code is in force as from 01.01.2010.

58 Denmark/Consolidated Act no. 1068 of 06.11.2008 om Straffeloven.

59 Malta/ HYPERLINK

"http://www.doi.gov.mt/EN/parliamentacts/2009/Act\%20XI\%20Criminal\%20Code.pdf" Act No. XI of 2009 - entitled the Criminal Code (Amendment) Act, 2009, HYPERLINK

"http://www.doi.gov.mt/EN/parliamentacts/2009/Act\%20XI\%20Criminal\%20Code.pdf" htt p://www.doi.gov.mt/EN/parliamentacts/2009/Act\%20XI\%20Criminal\%20Code.pdf (12.01.2010).

60 Slovakia/zákon 257/2009 (16.06.2009); Slovakia/zákon 300/2005 (20.05.2005). 


\section{Specific areas of social life}

This Chapter looks at information and developments on racism and discrimination in four areas of social life - employment, housing, education and healthcare - and then looks at a number of other issues not already covered by these four thematic areas. All of the material in this chapter relates to migrants and minorities in the EU, namely third-country nationals, second or third generation immigrants - in some countries known as ethnic minorities - and members of traditional national minorities.

As stated in the Introduction, since the Lisbon Treaty, EU law for the first time makes reference to 'persons belonging to minorities' and 'membership of national minorities'. As regards national minorities, it should be underlined that whether or not a given minority is recognised a 'national minority' belongs to the sphere of competence of the Member States, as the EU has no powers do so. ${ }^{61}$ The respective situations and the status provided diverge considerably among Member States and even within single Member States. This can even be the case within one group of persons belonging to national minorities. For example, Roma can enjoy markedly different treatment in the various EU countries and also within one country. However, all of the Member States except France signed the Council of Europe's Framework Convention for the protection of National Minorities (FCNM). Almost nine tenths of the EU Member States - with the exception of Belgium, France, Greece and Luxembourg - have committed themselves to a common European standard by ratifying the FCNM, thereby providing some sort of recognition and protection in line with this central document. The FCNM is thus flexible enough to accommodate the diverging historic and political contexts in the Member States.

In 2008, the European Parliament requested the FRA to draft a report on the question of minorities, including national minorities, which are vulnerable to ethnic and racial discrimination. The FRA agreed to update its 2007 report on racism and provide the Parliament on the basis of this request with a report on persons belonging to minorities, based on data and information collected in 2008 and 2009. This report was finalised in May 2010 and presented to the

61 Which does not imply that certain restrictive practices would not be criticised in the international arena. On February 2009, the Commissioner for Human Rights of the Council of Europe published a report on Greece regarding human rights of minorities criticising inter alia the authorities' refusal to recognise the existence of any other kind of minority except for the 'Muslim' one. See CommDH(2009)9, Human rights of minorities, Strasbourg, 19 February 2009, at https://wcd.coe.int/ViewDoc.jsp?id=1409353. See also the most recent ECRI Report on Greece, Fourth Monitoring Cycle, 15.09.2009, at http://www.coe.int/t/dghl/monitoring/ecri/Country-by-country/Greece/GRC-CbC-IV-2009031-ENG.pdf (21.01.2010). See already the judgement of the ECtHR delivered in July 2008 in Sidiropolous and others v. Greece (application no. 57/1997/841/1047). 
Committee on Civil Liberties, Justice and Home Affairs (LIBE) of the European Parliament in June $2010^{62}$.

In any event, the Member States stand under a human rights obligation to guarantee freedom of association and other basic fundamental rights that are of special relevance to persons belonging to minorities. ${ }^{63}$ Examples in this regard include the ending of exploitation in the labour market, the fight against structural disadvantages in the housing sector (a point of special relevance to the Roma), the provision of access to education, the provision of nondiscriminatory education (including an adequate representation of minorities in school text books) and access to healthcare. Other relevant issues addressed in this chapter include participation in public life, the right to practice one's religion and the use of minority languages in public, as well as the danger that elections are misused for anti-minority discourse.

In 2009, the FRA published the findings of its research on The situation of Roma EU citizens moving to and settling in other EU Member States, ${ }^{64}$ drawing on interviews with Roma individuals and officials on how the right to free movement and residence of Roma in the EU is experienced in several EU Member States. ${ }^{65}$ The findings show that poverty and racism - including unemployment, segregation and a feeling of 'not belonging' - are the main factors 'pushing' Roma to leave their countries of origin, with 'pull' factors being the desire to find work and improve their living standards in the destination countries. Roma experiences varied considerably between Member States - some local authorities supported Roma in promoting their access to the labour market, while others were keen to remove them and prevent them from coming. Overall, few strategies were in place to assist the integration of Roma EU citizens by public authorities in receiving countries, and some Roma could be even more marginalised than they had been in their countries of origin.

62 FRA (2010) Respect for and Protection of Persons Belonging to Minorities, Luxembourg: Publications Office of the European Union.

63 Regarding Greece the UN CERD expressed in 2009 its concern about the obstacles encountered by persons belonging to some ethnic groups in exercising the freedom of association. CERD recommends that the State party 'adopt measures to ensure the effective enjoyment by persons belonging to every community or group of their right to freedom of association and of their cultural rights, including the use of mother languages'. UN $\mathrm{CERD} / \mathrm{C} / \mathrm{GRC} / \mathrm{CO} / 19$, Concluding observations of the Committee on the Elimination of Racial Discrimination on Greece (28.08.2009), p.5, see http://www2.ohchr.org/english/bodies/cerd/docs/CERD.C.GRC.19EN.doc

64 FRA (2009) The situation of Roma EU citizens moving to and settling in other EU Member States, Luxembourg: Publications Office of the European Union.

65 The project formed part of a joint action initiated in 2008 in conjunction with the Council of Europe Commissioner for Human Rights (CommHR), the OSCE Office for Democratic Institutions and Human Rights (ODIHR) and the OSCE High Commissioner on National Minorities (HCNM). 


\subsection{Racism and discrimination in employment}

In 2009 the area of employment continues to be identified as the area of social life where discrimination is reported the most: for example in France, ${ }^{66}$ Germany ${ }^{67}$ and Spain. ${ }^{68}$ As with previous years, the indicators of the problem of racial discrimination in employment came from a number of complementary sources.

\subsubsection{Indirect statistical evidence of discrimination}

In the UK, a report indicated that ethnic minority unemployment rates were double those for white people; however, it also demonstrated progress over time, in that minority employment rates continued to converge with that of the majority. ${ }^{69}$ An initial indicator of a potential problem of discrimination derives from statistical patterns that show inequality between migrants/minorities and the majority population despite equivalence in qualifications and other relevant criteria. In 2009 surveys showed this for migrant workers in Italy ${ }^{70}$ and ethnic Russians in Estonia. ${ }^{71}$

\subsubsection{Incidents and cases of discrimination}

In Austria, miscellaneous cases of employment discrimination were recorded by NGOs: for example, harassment by work colleagues without superiors

66 Source: HALDE, Annual Report 2008, available at : http://www.halde.fr/IMG/pdf/RA UK version integrale.pdf (21.01.2010).

67 M. Sauer (2009) Türkischstämmige Migranten in Nordrhein-Westfalen und in Deutschland: Lebenssituation und Integrationsstand. Ergebnisse der neunten Mehrthemenbefragung, Essen: ZfT, p. 166.

68 Universidad Pública de Navarra, Gabinete de Estudios de CCOO (2008) Encuesta a la población inmigrante en Navarra 2008, Pamplona: Gobierno de Navarra, available at: http://www.navarra.es/NR/rdonlyres/6C9D5AD1-D29A-4D14-85C8DACD502AE56A/124841/Encuesta2008InformeFinal.pdf (20.08.2009).

69 Department for Communities and Local Government (DCLG) (2009) Improving Opportunity, Strengthening Society: A third progress report on the Government's strategy for race equality and community cohesion. London: DCLG, available online at:

http://www.communities.gov.uk/publications/communities/raceequalitythirdreport, notably Volume 1 Report at http://www.communities.gov.uk/documents/communities/pdf/11529661.pdf and Volume 2 Race Equality in Public Services - Statistical Report at http://www.communities.gov.uk/documents/communities/pdf/11529061.pdf.

70 A survey of 200 clerical and manual workers conducted in Milan: Z. Dazzi (2009) 'I lavoratori immigrati pagati il $20 \%$ in meno', in La Repubblica (17.06.2009). Available at: http://espresso.repubblica.it/dettaglio-local/i-lavoratori-immigrati-pagati-il-20-inmeno/2102058 (21.01.2010).

71 T. Vihalemm (ed.) (2009) 'Quality of Life and Integration', in: Estonian Human Development Report 2008, Tallinn, p. 101. The sociological analysis was based on official statistical data from previous years. Available at http://www.kogu.ee/public/EIA2008_eng.pdf (01.09.2009). 
intervening; employees in a hairdresser's shop being forced to take on Austrian sounding names; ${ }^{72}$ a man refused employment as a kitchen assistant because he spoke German with an accent; a qualified Nigerian man rejected because 'the customers would not accept his skin colour'. ${ }^{73}$ In Poland, several complaints of labour discrimination were identified, including Roma assistants receiving inferior contracts, ${ }^{74}$ and a Nigerian football player denied his contractually-due pay. ${ }^{75}$ In Ireland, the Equality Tribunal awarded $€ 20,000$ in compensation to a woman for racial discrimination in dismissal. ${ }^{76}$

Further examples of incidents of discrimination reported in 2009 are as follows:

In Hungary: a woman of Roma (Sinti) origin applied for an advertised position at a bakery. The representative of the employer rejected her application, explaining that work colleagues would not like to have a Gypsy co-worker. After an NGO submitted the case to the Equal Treatment Authority the bakery agreed to pay the woman financial compensation. ${ }^{77}$

In the Netherlands: an instruction was circulated to branches of a supermarket chain not to take on applicants of Moroccan descent. ${ }^{78}$ Following the leaking of the instruction, a local anti-discrimination agency ${ }^{79}$ took the case to the Equal Treatment Commission and reported the case to the police. The instruction was withdrawn by the company, who agreed not to discriminate in its recruitment procedures. ${ }^{80}$

In France: a job applicant was rejected by a baker because of his skin colour. The bakery owner refused a settlement proposed by the HALDE, and the case was therefore taken to magistrate's court, where the baker was fined $€ 5,000{ }^{81}$

In Germany: a kitchen assistant of south-east Asian origin in a Berlin restaurant complained of continuous racist verbal attacks and threats by

72 ZARA, Rassismus Report 2008, available at:

http://www.zara.or.at/_doc/2009/ZARA_RassismusReport2008.pdf(11.09.2009).

73 Helping Hands Graz, $\bar{J}$ ahresbericht $200 \overline{8}$, available at:

http://helpinghands.htu.tugraz.at/2008.pdf (15.07.2009).

74 The information about the situation of Roma assistants given in the letter from the Warmińsko-Mazurski Voivod Plenipotentiary for National and Ethnic Minorities to the Helsinki Foundation for Human Rights dated 09.09.2009, ref. no. BW.I.0714/33/09.

75 Information received from The Halina Nieć Legal Aid Center; e-mail to the Helsinki Foundation for Human Rights dated 11.09.2009.

76 Equality Tribunal; Decision DEC-E2009-011; Oksana v Goode Concrete Ltd; available at: http://www.equalitytribunal.ie/index.asp?locID=164\&docID=1989 (25.11.2009).

77 Nemzeti és Etnikai Kisebbségi Jogvédö Iroda (NEKI ), see e.g. http://www.eumap.org/journal/features/2002/may02/echrandhunroma (29.09.2009))

78 http://www.ad.nl/ad/nl/1004/Economie/article/detail/411482/2009/07/15/Geen-Marokkanenin-AH-to-go-winkels.dhtml (17.09.2009).

79 Bureau Discriminatiezaken Den Haag.

80 http://www.discriminatiezaken.nl/doc/AH\%20to\%20Go2.pdf (15.09.2009).

81 Source : HALDE, Annual Report 2008, available at : http://www.halde.fr/IMG/pdf/RA UK version integrale.pdf (22.01.2010). 
colleagues, initiated mainly by the chef. The victim informed his employer, but after internal talks the main perpetrator continued his discriminatory behaviour, reportedly seeking to drive the victim out of the restaurant. An NGO sent a letter of complaint to the employer, drawing attention to other incidents of the perpetrator's racist and homophobic threats to other employees, and the chef was dismissed. ${ }^{82}$

National Courts have continued to deal with racial and/or ethnic discrimination, sometimes also in cases of 'instruction to discriminate'. For instance, in France, a judgment delivered on 23 June 2009 by the French Court of Cassation $^{83}$ found that several companies and an individual had committed ethnic discrimination when hiring employees via interim agencies.

In the UK, a local London newspaper decided to test responses to discriminatory instructions. Posing as a window cleaning business, it contacted local recruitment agencies, saying it wanted to recruit temporary staff, but that it did not want to be sent any ethnic minorities. The newspaper found that 54 per cent of the agencies agreed to supply only workers from a majority background. ${ }^{84}$

\section{Discriminatory job advertisements}

As stated in last year's Annual Report, the problem of discriminatory job advertisements continues and remains present in several countries. This year, the problem was noted by NGOs in Austria ${ }^{85}$ and Spain (Catalonia ${ }^{86}$ and Navarra ${ }^{87}$ ) In Germany, advertisements requiring "mother-tongue German" were reported, ${ }^{88}$ and in Slovenia an advertisement offered a job to third-country nationals with wages below the minimum wage. ${ }^{89}$

\footnotetext{
82 Antidiskriminierungsnetzwerk Berlin (ADNB) Antidiskriminierungsbericht 2006- 2008, p. 12; available at: http://tbb-berlin.de/downloads_adnb/ADNB-

Antidiskriminierungsreport 2006-2008.pdf (30.07.2009).

83 France/Court Cassation/Criminal Chamber/n07-8509/ (23.06.2009), http://www.legifrance.gouv.fr/affichJuriJudi.do?oldAction=rechJuriJudi\&idTexte=JURITEX $\underline{T} 000020875114 \&$ fastReqId $=703220577 \&$ fastPos $=4$ (14.10.2009).

84 http://www.rec.uk.com/press/news/730

85 ZARA, Rassismus Report 2008, available at: http://www.zara.or.at/ doc/2009/ZARA RassismusReport2008.pdf (11.09.2009) and Helping Hands Graz, Jahresbericht 2008, available at: http://helpinghands.htu.tugraz.at/2008.pdf (15.07.2009).

86 SOS Racisme, Oficina d'Informació i Denúncies, Memòria 2008, available at: http://www.sosracisme.org/denuncia/oid.php\#part7 (26.06.2009).

87 SOS Racismo Navarra, Informe anual año 2009 sobre el racismo en Navarra.

88 ECRI (2009) Fourth report on Germany, Strasbourg: ECRI, p. 23

89 Data submitted by the Advocate of the Principle of Equality upon request.
} 


\subsubsection{Surveys of minorities and the majority population}

Another source of evidence on discrimination is surveys of both minority and majority populations. In the FRA's EU-MIDIS survey, published in 2009, significant proportions of migrant and minority respondents reported subjective experiences of discrimination, both when looking for work, and at the workplace..$^{90}$ As well as this EU-wide study, there were several national studies in 2009. In a German survey of almost 1,600 migrants, ${ }^{91} 23$ per cent felt they had suffered discrimination, and in a survey of migrants of Turkish origin, half felt that they had experienced discrimination at the workplace and 43 per cent when looking for work. ${ }^{92}$ In a Spanish survey ${ }^{93}$ of migrants in Navarra, 42 per cent felt discriminated against at least once, and in an Italian survey 50 per cent of immigrant workers reported racist insults. ${ }^{94}$

In FRA's 2009 EU-MIDIS survey, 38 per cent of Roma jobseekers felt that they had been discriminated against at least once when applying for a job in the 12 months preceding the survey. Twenty-two per cent of Sub-Saharan African and 20 per cent of North African jobseekers indicated the same. For those in work, 19 per cent of Roma felt they had suffered discrimination at the workplace in the 12 months preceding the survey. ${ }^{95}$

There were also examples of surveys of the majority population: in a survey of young people in northeast Poland more than half stated that they would not like to have a Roma as a work colleague or superior $;{ }^{96}$ in a Lithuanian phone survey almost 60 per cent of employers stated they would give priority to hiring

90 FRA (2009) EU-MIDIS Main Results Report, p. 42-43

91 Bertelsmann Stiftung (2009) Zuwanderer in Deutschland. Ergebnisse einer repräsentativen Befragung von Menschen mit Migrationshintergrund, pp. 67-71; available at: http://www.bertelsmann-stiftung.de/bst/de/media/xcms_bst_dms_29096_29097_2.pdf (31.07.2009)

92 M. Sauer (2009) Türkischstämmige Migranten in Nordrhein-Westfalen und in Deutschland: Lebenssituation und Integrationsstand. Ergebnisse der neunten Mehrthemenbefragung, Essen: ZfT, p. 166.

93 Universidad Pública de Navarra, Gabinete de Estudios de CCOO (2008) Encuesta a la población inmigrante en Navarra 2008, Pamplona: Gobierno de Navarra, available at: http://www.navarra.es/NR/rdonlyres/6C9D5AD1-D29A-4D14-85C8DACD502AE56A/124841/Encuesta2008InformeFinal.pdf (20.08.2009).

94 A survey of 200 clerical and manual workers conducted in Milan: Z. Dazzi (2009) 'I lavoratori immigrati pagati il $20 \%$ in meno', in La Repubblica (17.06.2009). Available at: http://espresso.repubblica.it/dettaglio-local/i-lavoratori-immigrati-pagati-il-20-inmeno/2102058

95 FRA (2009) EU-MIDIS Main Results Report, Luxembourg: Publications Office, p. 42.

96 T. Kasprzak, B. Walczak (2009) 'Diagnoza postaw młodzieży województwa podlaskiego wobec odmienności kulturowej: raport z badania', in: A. Jasińska-Kania, K. Staszyńska (eds), Diagnoza postaw młodzieży województwa podlaskiego wobec odmienności kulturowej, Białystok: Urząd Marszałkowski Województwa Podlaskiego, pp. 51-133. 
local citizens rather than refugees, ${ }^{97}$ and in Romania 44 per cent of respondents agreed that they would not hire a Roma, as they were seen to be "lazy and untrustworthy". ${ }^{98}$ In Germany, a study revealed widespread irrational fears and negative attitudes towards migrants and Muslims. ${ }^{99}$ In Sweden, while an increasing number of Swedes reported positive experiences with immigrants, attitudes towards Muslims have become more hostile, and Swedes are increasingly suggesting that the headscarf should be banned in workplaces. ${ }^{100}$

\subsubsection{Discrimination testing}

In Ireland, a testing experiment directly compared employers' responses to job applications from candidates who are identical on all relevant characteristics other than their ethnic or national origin. Job applicants with Irish names were over twice as likely to be invited to interview as candidates with identifiably non-Irish names, although both submitted equivalent curricula vitae (CVs). ${ }^{101}$

Researchers commissioned by the UK Department for Work and Pensions sent three different applications, each application under a British, African and Asian name, to 987 advertised jobs in cities in England and Scotland,. They found that whilst the 'white' applicant would send on average nine applications before receiving a positive response, the 'minority' applicants needed 16 applications for a similar response. The report, released in October 2009, concluded that there was no plausible explanation for the difference in treatment found between white British and ethnic minority applicants other than racial discrimination. It also found that public sector employers were less likely to have discriminated against applicants than those in the private sector. ${ }^{102}$

97 Lietuvos suaugusiuju švietimo ir informavimo centras [Lithuanian Centre for Adult Education and Information] at the request of Ruklos pabégeliu prièmimo centras [Rukla Refugee Reception Centre] in February 2009 and included a sample of 404 Lithuanian companies

98 Barometrul interetnic 2009 - Romii şi majoritarii (Inter-ethnic Barometer 2009: Roma and the Majority, research conducted by IMAS. Press release announcing all documents produced within the survey available at http://www.sgg.ro/index.php?implementare_program (17.09.2009).

99 Antidiskriminierungsstelle des Bundes (2009) Discrimination in Everyday Life. Perception of Discrimination and Anti-Discrimination Policy in our Society, Berlin: ADS, pp. 239, 241

100 The annual Mångfaldsbarometern (Diversity barometer] on the attitudes of Swedes towards immigrants: http://www.soc.uu.se/dok.php (29.10.2009). http://hd.se/inrikes/2009/10/29/fler-positiva-till-invandrare/ (29.10.2009).

101 The Equality Authority; Frances McGinnity, Jacqueline Nelson, Pete Lunn, Emma Quinn; 2009; Discrimination in Recruitment: evidence from a field experiment; available at: http://www.equality.ie/index.asp?docID=794 (23.10.2009).

102 http://www.guardian.co.uk/money/2009/oct/18/racism-discrimination-employmentundercover 


\subsubsection{Informal recruitment}

In a 2009 Danish survey, 13 per cent of public employees and 36 per cent of private sector employees reported that their bosses employed friends or family members for jobs. One implication is that this is likely to disadvantage ethnic minorities, who have weaker networks among business leaders. ${ }^{103}$ Informal recruitment also has implications the other way round - a survey in Austria found that migrants, particularly in lower skilled jobs, are more likely than Austrians to have found these jobs with the help of relatives or friends. In this way the operation of informal networks reinforces the concentration of migrants in certain sectors and occupations. ${ }^{104}$

\subsubsection{Religious and cultural symbols at work}

In several Member States the debate on religious and cultural symbols at work provides an on-going discussion on the balance of the rights of religious and cultural groups on the one hand and the separation of church and state, the interests of public security, and rights of children and others, on the other. Different solutions have been chosen in different Member States, which are often determined by the particular concrete national context.

In Denmark, the 'headscarf debate' continued regarding the police force, where religious headgear is banned, ${ }^{105}$ and the Danish Home Guard, where a Muslim woman was forbidden to wear the headscarf. ${ }^{106}$ Whilst a public opinion survey in Denmark concluded that the majority of respondents were against Muslims' right to wear a headscarf and to pray during the working day, ${ }^{107}$ another survey showed that nine out of ten Danish companies had no problem with these issues, and one of the major supermarket chains announced that their strategy

103 K Birkedal Kristensen (2009) 'Danske Chefer ansætter Venner og familie' in LO-Ugebrev A4, (17.08.09) http://ugebreveta4.dk/2009/200926/baggrundoganalyse/danske_chefer_ansaetter_venner_og familie.aspx (19.08.2009)

104 Statistik Austria (2009) Arbeits- und Lebenssituation von Migrantinnen und Migranten in Österreich: Modul der Arbeitskräfteerhebung 2008, available at: http://www.statistik.at/dynamic/wcmsprod/idcplg?IdcService=GET_NATIVE_FILE\&dID=55 196\&dDocName $=041111 \quad(30.10 .2009)$.

105 No author named, (2009) 'Dansk politi alene om tørklædeforbud, Ritzaus Bureau, 05.02.2009.

106 Hjemmeværnskomandoen, (2009) 'Uniformsbestemmelser skal overholdes' at The Danish Home Guards' homepage , 19.07.2009, http://www.hjv.dk/Nyheder/Sider/Uniformsbestemmelserskaloverholdes.aspx (01.10.2009).

107 M. Bræmer (2009) 'Lønmodtagerne ramt af muslimforskrækkelse' in Ugebrevet A4, 06.04.09:

http://www.dua.dk/2009/200913/Baggrundoganalyse/Loenmodtagerne_er_ramt_af_muslimforskraekkelse.aspx (15.08.2009). 
was to recruit women with headscarves to improve integration and match the diversity in wider society. ${ }^{108}$

In Germany, a report by Human Rights Watch concluded that bans in eight German Länder prohibiting teachers (and some other civil servants) from displaying religious symbols contravene Germany's international legal obligations and are discriminatory against Muslim women, forcing some Muslim women to choose between their job and their religious belief. ${ }^{109}$

In a case in the Netherlands, the Commissie Gelijke Behandeling (CGB) [Equal Treatment Commission] ruled that the Amsterdam police were not guilty of discrimination in refusing to allow a staff member to wear a headscarf when in uniform in a position where she was in contact with the general public. ${ }^{110}$

\subsubsection{Statistics and ethnic monitoring}

In the UK Census of Population in 2011 added to questions on the ethnic origins of the population will be one on the Gypsy/Irish Traveller and Arab populations, as well as questions about national identity. ${ }^{111}$ In Germany, the census in 2011 will, for the first time, gather data on migration background and national origin. ${ }^{12}$ In Belgium ${ }^{113}$, the Flemish regional government piloted with employers a monitoring instrument for its diversity policy based on the origin of employees. $^{114}$

In France the debate on ethnic statistics continued in the media, with part of scientific opinion (e.g. INED [Institut national d'études démographiques]) in favour of the elaboration of ethnic statistical data, whilst the HALDE, as well as a number of NGOs like SOS Racisme and LICRA, being opposed to statistics

\footnotetext{
108 The COOP chain. On the other hand, another supermarket chain, FØTEX, has a policy banning religious dress and won a case on this in High Court in 2005.

109 Human Rights Watch (2009) Discrimination the Name of Neutrality. Headscarf Bans for Teachers and Public Servants in Germany, p. 2; available at: www.hrw.org/sites/default/files/reports/germany0209_web.pdf (31.07.2009) Muslim teacher trainees have been denied subsequent employment as teachers after they have completed their training - unless they take off their headscarves. According to the findings of the qualitative interviews, many of the interviewed women feel 'alienated and excluded' (p.3) - although some of them had been living in Germany for decades.

110 The Netherlands/CGB/2008-123 (23.10.2008).

111 The question content can be viewed at: http://www.ons.gov.uk/census/2011-census/2011census-questionnaire-content/index.html

112 According to Sec. 3 and 7 of the recently adopted Census 2011 Act (ZensG 2011)

113 As part of the EAD - 'Impulsbeleid Evenredige Arbeidsdeelname en Diversiteit (ImpulsePolicy Proportional Work Participation and Diversity) - an instrument to stimulate diversity and participation of minorities in the labour market. See website of EAD: http://www.werk.be/beleid/div/?SMSESSION=NO, (26.08.2009)

114 Information provided by the Flemish Agency of Internal Administration (Agentschap voor Binnenlands Bestuur), 19.08.2009
} 
based on ethnic origin. ${ }^{115}$ In Bulgaria, where legislation forbids labour statistics by ethnicity unless they are based on self-identification, it was reported that Roma do not identify themselves as such, even when self-identification might lead to eligibility for special programmes or new opportunities, due to fear of stigma and experiences of prejudice. ${ }^{116}$ This makes it hard to identify statistical indicators of discrimination.

In the FRA EU-MIDIS survey the 23,500 migrant and minority respondents were asked if they would be in favour of providing information on an anonymous basis about their ethnic origin as part of a census, if that could help to combat discrimination. Sixty-five per cent of all respondents said that they would be willing to do so. ${ }^{117}$

\subsubsection{Discriminatory legislation}

The term 'discriminatory legislation' refers to a kind of 'legal discrimination' against non-EU nationals. With regard to the area of employment, the dominant issue here is that of regulations which restrict the access of such non-nationals to public sector jobs. The varying extent to which EU Member States operate such restrictions is covered in some detail in a 2009 FRA overview report on employment discrimination issues in the EU, which concludes that "Public sector exclusion is (...) one factor that increases the vulnerability of non-EU migrant workers and contributes to their marginalisation in European labour markets". ${ }^{118}$

Examples in 2009 which fall under this heading were found in Italy, where five long-term legally-resident non-EU nurses were excluded from a selection process by a hospital in Genoa on the grounds that they did not possess Italian or other EU citizenship. The head of personnel at the hospital insisted that nurses are public officials and as a consequence only Italian citizens can be employed in such posts. ${ }^{119}$ Another example was the public transport company of Milan, which was found guilty of discriminating against legally-resident third

\footnotetext{
115 See for instance : http://www.lepoint.fr/actualites-societe/2009-05-07/statistiques-ethniquesyazid-sabeg-veut-montrer-le-vrai-visage-de-la-france/920/0/328176

116 Center for the Study of Democracy (2009) Interview with the Head of Intermediaries Department at Serdika Unemployment Bureau, Timok Branch (21.07.2009). According to the interviewee, the only field free of discrimination is the cleaning industry (streets cleaning, garbage collection, etc.), where even ex-convicts of Roma origin could easily find a job.

117 FRA (2010) Data in Focus Report "Rights awareness and equality bodies" Luxembourg: Publications Office, p.12

118 Migrants, Minorities and Employment: Exclusion and Discrimination in the 27 Member States of the European Union FRA, Vienna 2010, Chapter 5.

119 See M. Calandri (2009) 'Concorso per infermieri, esclusi gli immigrati', in La Repubblica Genova.it (27.05.2009). Available at: http://genova.repubblica.it/dettaglio/concorso-perinfermieri-esclusi-gli-immigrati/1640650
} 
country nationals for requiring Italian or EU citizenship for access to work in the company. ${ }^{120}$

In its report on Austria, adopted in 2009, the Council of Europe's ECRI ${ }^{121}$ criticised the Austrian legislation which allows employers, when making staff cuts, to dismiss foreign workers first. In its previous reports, ECRI had already called for the repeal of Section 8(2) of the Aliens Employment Act No. $218 / 1975$. This provision was also found by the European Committee of Social Rights to be incompatible with Article $1 \S 2$ of the European Social Charter: although the scope of the disputed provision has been reduced since 2005 (it now applies only to foreign workers when they first enter the labour market). Section 8(2), which provides that in the event of reduced activity in the company, the employment contracts of foreign nationals may be terminated if such action might prevent shorter working hours for all workers, still constitutes discrimination based on nationality and is therefore incompatible with Article 1 $\S 2$ of the Charter ${ }^{122}$.

\subsubsection{Extreme exploitation}

In 2009 there were a great many reports of extreme exploitation of migrant workers, often made possible by their legal vulnerability. There are descriptions of insecure workers suffering a range of injustices, including insults and harassments, having to work extremely long hours in unhealthy conditions in violation of labour regulations, being paid less than collective agreements, and denied sickness leave. There are several instances of groups of workers not being paid at all for their work. In other cases workers have had their passports confiscated and been confined in their sub-standard accommodation without freedom to leave, or have had the cost of their meagre accommodation and food deducted from their wages.

The Netherlands: the Public Prosecutor started a criminal investigation into a farmer who had her foreign, mainly Romanian, contract employees housed in appalling conditions, and underpaid. The employer had confiscated their passports; they were not allowed to leave the premises and were sometimes locked in their narrow attic rooms, several of which had no windows. ${ }^{123}$

Cases reported during 2009 of the extreme exploitation of such workers were found in a number of countries, for example: foreign agency workers in the

120 Italy/Tribunale di Milano - Sezione Lavoro - Ordinance of 20 July 2009. Available at: http://www.asgi.it/public/parser_download/save/tribunale_milano_lavoro_200709.pdf

121 European Commission against Racism and Intolerance.

122 ECRI report on Austria (fourth monitoring cycle), 2 March 2010, § 55, available at: http://www.coe.int/t/dghl/monitoring/ecri/Country-by-country/Austria/AUT-CbC-IV-2010002-ENG.pdf

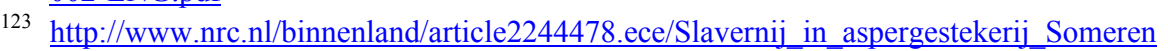
(17.09.2009). 
Czech Republic, ${ }^{124}$ berry pickers from South East Asia and Eastern Europe in Finland $;{ }^{125}$ foreign workers in the cleaning sector in Greece; ${ }^{126}$ Moldavian and Ukrainian citizens in Lithuania; ${ }^{127}$ Africans in Malta; ${ }^{128}$ Chinese construction workers ${ }^{129}$ and African taxi drivers in Romania; ${ }^{130}$ workers from Bosnia and Herzegovina in Slovenia; $;{ }^{131}$ female domestic workers in Cyprus, ${ }^{132}$ and Moroccan textile workers and Chinese sweatshop workers in Spain (Andalusia ${ }^{133}$ and Catalunya respectively).

124 Český helsinský výbor (2009) Zpráva o stavu lidských práv v roce 2008. Available at http://www.helcom.cz/view.php?cisloclanku=2009042107 (14.09.2009).

125 Finland/Vähemmistövaltuutettu, 'Vähemmistövaltuutettu ehdottaa marjanpoimijoiden aseman tarkistusta' (14.04.2009); Helsingin Sanomat (2009), 'Poliisi tutkii marjanpoimijoiden työkiistaa Lapissa' (23.08.2009).

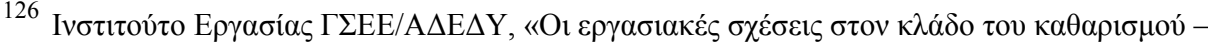

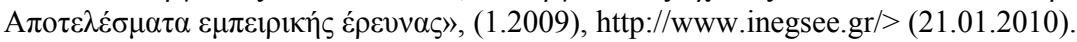

127 All information provided by the Embassy of the Republic of Moldova to the Republic of Lithuania and the association of trade unions Solidarumas. Communication of the NFPLithuania (Centre of Ethnic Studies at the Institute for Social Research) with the association of trade unions Solidarumas, (07.08.2009).

128 Source: interview with representative of the General Workers Union; see the GWU (2008) Policy paper on migrant workers.

129 The New York Times, Chinese workers stranded in Romania, from 06.02.2009, available at http://www.nytimes.com/2009/02/16/world/europe/16iht-migrants.4.20224539.html (29.09.2009); Chinese Embassy in Bucharest, Press release from 17.04.2009 available at http://www.mfa.gov.cn/ce/cero/rom/xw/t557754.htm (29.09.2009). See also Realitatea, Muncitorii chinezi care au stat în corturi, în fața ambasadei Chinei, au plecat acasă, from 16.04.2009 available at http://www.realitatea.net/muncitorii-chinezi-care-au-stat-in-corturi-in-fata-ambasadei-chinei--au-plecat-acasa 497542.html (29.09.2009)

130 Evenimentul Zilei, Andrei Craciun, Congolezi in sclavie pe taxiuri, 22.12.2008, available at http://www.evz.ro/articole/detalii-articol/833340/Congolezi-in-sclavie-petaxiuri/(20.09.2009).

131 G. Lukič, K. Medica, J. Nemanič (2008) National Report on the Situation of Migrant Workers in Slovenia, available at: http://www.emffem.org/content/download/28573/241447/file/Migrant $\% 20$ workers\%20Slovenia.pdf (02.10.2009); Zveza svobodnih sindikatov Slovenije (2008) Analiza položaja delavcev migrantov $v$ perspektivi kršitve $v$ zvezi $z$ delom in zaposlovanjem tujcev ter njihovimi bivalnimi pogoji, available at: http://www.zsss.si/images/stories/PDF\%20aktualno/ANALIZA_POLOZAJA_DELAVCEVM IGRANTOV ZSSS 171208.pdf (02.10.2009).

132 Cyprus Review, Vol. 21, no.1, spring 2009, pp. 59-80.

133 More information at: http://www.elmundo.es/papel/2009/01/16/espana/2578789.html (10.09.2009). 
Spain: In May 2009, an irregular Bolivian migrant who worked in a bakery in Valencia lost an arm in a work-related accident. The owners of the bakery allegedly abandoned the worker near a hospital and threw the arm in a rubbish tip. It later transpired that he had worked 12 hours a day, earned $€ 700$ per month without holidays, and that the accident was caused by a non-compliance with safety procedures. Spanish trade unions supported the worker, and the case has gone to court. ${ }^{134}$

Measures to help combat the exploitation of irregular workers are discussed in Section 6.1.1 of this report.

134 See, for instance, http://www.pv.ccoo.es (01.07.2009); http://www.state.gov/g/drl/rls/hrrpt/2008/eur/119074.htm (29.09.2009). 


\subsection{Racism and discrimination in the housing sector}

\subsubsection{Research findings}

As with the area of the labour market, evidence for discrimination in the access of migrants, Roma and Travellers, refugees and asylum seekers to the housing market is convincingly highlighted through specific research projects. Also as with the area of employment, indirect indications of the problem came from statistical patterns, and direct evidence came from testing experiments.

In France, ISM Corum, with the City of Lyon's limited liability building company (SACVL), carried out a survey on the allocation of social housing. The study covered the SACVL housing pool of 7,980 housing units. First, all the households were divided into two groups: the first group comprising families with surnames which make it likely that the families are discriminated against; the second group comprises of families with surnames which make discrimination unlikely. The study revealed that 69 per cent of the households of the first group live in the least attractive housing, compared to only 46 per cent of the second group. ${ }^{135}$ In Germany, a multi-topic survey of the Zentrum für Türkeistudien (ZfT) revealed that housing continues to be a social area where many migrants of Turkish background experience discrimination: four out of ten respondents reported experience of discrimination when trying to find a flat; about one quarter of all respondents experienced discrimination in their immediate neighbourhood. ${ }^{136}$

In the FRA's 2009 EU-MIDIS survey, 11 per cent of Roma respondents and 11 per cent of North Africans reported that they had been discriminated against in the past 12 months by housing services, an agency or a landlord. In comparison with the area of work, the discrimination rates are markedly lower in the area of housing, and, in particular, those respondents with a Turkish, Russian and former Yugoslav background all report extremely low rates of discrimination in this domain. Interestingly, the relatively high rates of discrimination reported by all the respondent groups in Italy suggest a country-specific problem in this field. ${ }^{137}$

\footnotetext{
${ }^{135}$ HALDE (2008) Rapport Annuel 2008, p.55, available at: http://www.halde.fr/-AnnualReports-.html?page=rubrique en (17.12.2009).

136 M. Sauer (2009) Türkischstämmige Migranten in Nordrhein-Westfalen und in Deutschland: Lebenssituation und Integrationsstand. Ergebnisse der neunten Mehrthemenbefragung, Essen: ZfT, p. 166, (17.12.2009).

137 FRA (2010) EU MIDIS Main Results Report, Luxembourg : Publications Office, p. 44.
} 
In a few countries, discrimination tests were carried out in order to research discrimination against migrant and ethnic minority groups in access to the housing market. In Belgium, in 2009 the Brussels association Comité ALARM carried out a test ${ }^{138}$ in Brussels in relation to 101 offers of rented housing. First an 'applicant' phoned the landlord, speaking with accent and giving an African name. Ten minutes later another 'applicant' called, speaking without an accent and giving a 'Belgian' name. In 28 cases, the second applicant got a different answer than the first one - a clear pointer to discrimination. The test was methodologically supported by the Centre for Equal Opportunities and Opposition to Racism (CEOOR), the Belgian National Equality Body. In France, the national Equality Body, the HALDE, following complaints, carried out a series of discrimination tests on private sector landlords in the Paris region as well as in other regions. The HALDE discrimination tests resulted in six referrals to the public prosecutor at the beginning of $2009 .{ }^{139}$

In Germany, the NGO Planerladen published in 2009 the results of an explorative discrimination testing project on the housing market, carried out between July 2007 and June 2008. In seven cities in North Rhine-Westphalia, 482 flat advertisements, posted in regional newspapers, were tested by two matched testers, one of them "German", the other one of "Turkish origin"; the contact was made via telephone. Whereas in 79 per cent of the cases both testers received the same response, in 19 per cent of the cases, the "Turkish" tester was treated less favourably; the "Turkish" tester received twice as many rejections as the "German" tester. ${ }^{140}$

In Sweden, the Equality Ombudsman has been mandated by the Ministry on Gender Equality and Integration to investigate the extent of discrimination in the housing market. The Equality Ombudsman will use discrimination testing as a method for its investigation of the occurrence of discrimination. The inquiry will be nationwide and comparisons will be done between regions, type of housing, the private and public sector and between women and men. ${ }^{141}$

138 ALARM - Action for Accessible Housing for Refugees in Molenbeek [Action pour le Logement Accessible aux Réfugiés à Molenbeek], founded in 2001. More information about the association in: Flemish Minority Centre (VMC), Coloured Poverty [Gekleurde Armoede], Brussels, 2008, p. 9-10, available at: http://www.vmc.be/uploadedFiles/VMC/Diverse/inspiratieboekje\%20A4.pdf (30.09.2009).

139 HALDE, Rapport Annuel 2008, p.54, available at: http://www.halde.fr/-Annual-Reports. html?page=rubrique en $(17.12 .2009)$.

140 Planerladen e.V. (2009) Ungleichbehandlung von Migranten auf dem Wohnungsmarkt. Ergebnisse eines telefonischen "Paired Ethnic testings" bei regionalen Immobilienanzeigen, availavle at: www.planerladen.de $/ 50 . h t m l$ ? \&tx_ttnews[tt_news] $=208 \&$ tx_ttnews[backPid] $=7 \& \mathrm{cHash}=080$ c4f6dd8 (22.08.2009)

141 More information available at: http://www.regeringen.se/sb/d/11290/a/133678 (22.01.2010). 


\subsubsection{Discrimination and advertisements}

Again, as with the area of employment, discriminatory advertisements were found to be a problem. In Germany, the Berlin-based Anti-Discrimination Office [Landesstelle für Gleichbehandlung - gegen Diskriminierung, ADNB] reported a relatively new development: 'lacking German proficiency' has been used as an argument for rejecting migrants looking for a flat. ${ }^{142}$ Additionally, the 2009 European Commission against Racism and Intolerance (ECRI) report on Germany stressed that "NGOs report that a key role is played by discriminatory practices of landlords and property managers, based for example on a person's name or on their fluency in German. Cases in which rooms are advertised as 'available for mother-tongue German speakers only' are also reported". ${ }^{143}$ In the Czech Republic, several cases have been reported of real estate agencies advertising that a lease was not intended for "other nationalities" and "foreigners" or was "only for Czech nationals". In 2008 a nongovernmental organisation IQ Roma servis [IQ Roma Service] filed a complaint regarding one such case at a $\mathrm{CTI}^{144}$ regional inspectorate in Brno. ${ }^{145}$ In Spain the existence of discriminatory housing advertisements has been reported by the Ararteko [Basque Ombudsman] in his 2008 annual report ${ }^{146}$ as well as by the SOS Racismo Claim Office in Catalonia. ${ }^{147}$

In Sweden, in October 2009, the association $\mathrm{HSB}^{148}$ was obliged to pay 60,000 SEK (approximately 6,000 Euros) in damages for ethnic discrimination. A couple with a foreign background were denied the opportunity to purchase an apartment from the HSB-association in Örebro, despite the fact that they had made the highest bid. The couple made a complaint to the Equality Ombudsman and a settlement was reached whereby the couple received discrimination damages. ${ }^{149}$

142 Antidiskriminierungsnetzwerk Berlin (ADNB) Antidiskriminierungsbericht 2006- 2008, Berlin, pp. 13-14; available at: http://tbb-berlin.de/downloads adnb/ADNB-

Antidiskriminierungsreport_2006-2008.pdf (30.07.2009).

143 ECRI (2009), ECRI Report on Germany (fourth monitoring cycle), Strasbourg: ECRI, § 62, available at: http://www.coe.int/t/dghl/monitoring/ecri/Country-bycountry/Germany/Germany_CBC en.asp (16.12.2009).

144 Czech Trade Inspection (Česká obchodní inspekce)

145 Available at http://www.iqrs.cz/view.php?nazevclanku=posun-v-pristupu-coi-kdiskriminacnimu-jednani-realit-kancelari\&cisloclanku=2009030005 (14.09.2009).

146 Ararteko, Informe al Parlamento Vasco 2008, p. 577, available at: http://www.ararteko.net/RecursosWeb/DOCUMENTOS/1/9 1641 3.pdf (08.07.2009).

147 SOS Racisme, Oficina d'Informació i Denúncies, Memòria 2008, available at: http://www.sosracisme.org/denuncia/oid.php\#part7 (26.06.2009).

148 Hyresgästernas Sparkasse och Byggnadsförening (Tenants Savings and Building Society)

149 Available at: http://www.do.se/Om-DO/Stamningar-och-forlikningar/Forlikningbostadsrattsforening/ 


\subsubsection{The housing situation of Roma and Travellers}

In October 2009 the FRA published its Comparative Report on the Housing Conditions of Roma and Travellers in the European Union. ${ }^{150}$ The report provides evidence that Roma and Travellers are strongly disadvantaged in private and social housing throughout the European Union. This includes discrimination in access to housing, poor housing conditions, segregation, and forced evictions. Sometimes, Roma live in squalid shanty-towns and temporary camps, often in segregated and environmentally hazardous areas. Very often, Roma housing areas have poor access to public services, employment and schools, and are without adequate access to public utilities such as water, electricity or gas. The report highlights forced evictions from municipal accommodation, even of Roma who are regular rent payers. These evictions often happen without prior notice, and may involve police violence and destruction of personal property. There are many cases where authorities fail to provide alternative housing and/or adequate compensation for expropriation.

In its 2009 report on the Czech Republic, the Council of Europe's European Commission against Racism and Intolerance (ECRI) "is deeply concerned at the continued marginalisation of Roma, which is expressed, in the field of housing, through a variety of mechanisms: perpetuation of existing segregated localities, and creation of new ones; substandard living conditions; or the imposition of excessively high rents that lead quickly into a downward spiral of debt". ${ }^{151}$ In its report on Slovakia, ECRI noted with concern that "some of the social housing is being built in the same segregated areas where Roma previously lived. Therefore, although the new social housing provides better living conditions for Roma, they continue to be de facto segregated from the rest of the population". ${ }^{152}$ In Greece, the 2009 ECRI report noted that "the living conditions of some Roma continue to fall unacceptably below international standards", while "some Roma settlements are in complete isolation from the rest of the population, without running water or electricity and without a sewage system or access to public transport". ${ }^{153}$ The Greek Ombudsman, after many years of investigation, published in August 2009 a special report about the pending civil registration of the civil and municipal status of Roma as an underlying cause of their precarious housing conditions and the limited impact

150 FRA (2009) Comparative Report on Housing Conditions of Roma and Travellers in the European Union, available at: http://fra.europa.eu/fraWebsite/home/pub-cr-romahousing en.htm (22.01.2010).

151 ECRI (2009), Fourth Report on the Czech Republic, Strasbourg: ECRI, § 117,, available at: http://www.coe.int/t/dghl/monitoring/ecri/Country-by-country/Czech Republic/CZE-CbCIV-2009-030-ENG.pdf (15.09.2009).

152 ECRI (2009), Fourth Report on Slovakia, Strasbourg: ECRI, § 67, available at: http://www.coe.int/t/dghl/monitoring/ecri/Country-bycountry/Slovakia/Slovakia_CBC en.asp (21.12.2009).

153 ECRI (2009), Fourth Report on Greece, Strasbourg: ECRI, § 70, available at: http://www.coe.int/t/dghl/monitoring/ecri/Country-by-country/Greece/GRC-CbC-IV-2009031-ENG.pdf (21.12.2009). 
of housing policies. ${ }^{154}$ The Ombudsman noted that individuals who cannot provide evidence of their municipal status and 'permanent residence' in a municipality are blocked from accessing the government housing programme of state guaranteed low- or non-interest loans. In the context of the criticisms from the Greek Ombudsman there has been a legal reform of the mortgage loans scheme in Greece with the aim of giving priority to Roma who are faced with particular social difficulties.

In Poland, the continued social marginalisation and discrimination faced by members of the Roma minority in the field of housing have been pointed out by the UN Committee on the Elimination of Racial Discrimination (CERD). ${ }^{155}$ In Bulgaria, CERD has also expressed its concerns about the specific obstacles encountered by Roma in respect to access to housing and other areas of social life. ${ }^{156}$ In Slovenia, the Ombudsman reported several cases of discriminatory practices by real estate agencies and private individuals, preventing Roma families from buying or selling property. ${ }^{157}$ In Spain, the 2008 Annual Report of the Basque Ombudsman refers to a number of complaints received during 2008 that demonstrate the difficulties that many Roma continue to encounter in housing access. ${ }^{158}$ The Committee on the Elimination of Racial Discrimination noted that discrimination against Roma also remains a serious concern in Finland, where both Roma and immigrants face de facto segregation in housing. ${ }^{159}$

\subsubsection{Restrictions in access to housing}

In Belgium, in its 2009 report ECRI recommended that the Flemish authorities should review the new requirements related to language and integration in the Flemish Housing Code, as these requirements might have a counter-productive

\footnotetext{
154 See the Special Report on the civil registration of Greek Roma, presented by the Ombudsman

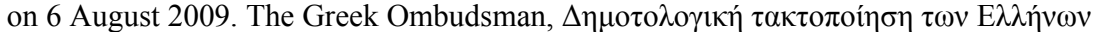

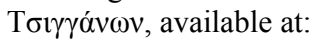
http://www.synigoros.gr/diakriseis/pdfs_01/8289_3_Dimotologisi_Roma_Eidiki_Ekthesi.pdf (21.12.2009).

155 CERD (2009) Consideration of reports submitted by states parties under article 9 of the convention. Concluding observations of the Committee on the Elimination of Racial Discrimination: Poland, 75th session, 3-28 August 2009, p. 3, available at: http://www2.ohchr.org/english/bodies/cerd/cerds75.htm (31.10.2009).

156 CERD (2009) Consideration of reports submitted by the states parties under article 9 of the Convention, Concluding observations of the Committee on the Elimination of Racial Discrimination: Bulgaria, 74th Session, 16 February - 6 March 2009, p.4, available at: http://www2.ohchr.org/english/bodies/cerd/cerds74.htm (29.09.2009).

157 Varuh človekovih pravic, Letno poročilo Varuha človekovih pravic Republike Slovenije za leto 2008, p. 48, available at: http://www.varuh-rs.si/fileadmin/user_upload/pdf/lp/Varuh_LP2008.pdf (02.10.2009).

158 Ararteko, Informe al Parlamento Vasco 2008, available at: http://www.ararteko.net/RecursosWeb/DOCUMENTOS/1/9 1641 3.pdf (08.07.2009).

$159 \mathrm{http} / / / \mathrm{www}$ 2.ohchr.org/english/bodies/cerd/docs/CERD.C.FIN.CO.19.doc (02.10.2009).
} 
effect on the integration process of non-Dutch speakers. ${ }^{160}$ The Council of Europe Commissioner for Human Rights voiced similar concerns. ${ }^{161}$ In Germany, CERD expressed its concerns about the "possible negative effects in terms of indirect discrimination on the grounds of ethnic origin, due to the exception to the principle of equal treatment as regards access to rental housing contained in paragraph 19, section III of the General Equal Treatment Act." Under this provision, landlords are able to refuse to rent apartments to certain persons through a desire to create and maintain "socially stable residential structures and balanced housing estates and also balanced economic, social and cultural conditions."162

In Italy, on 18th February 2009, the regulation on the temporary settlement in the authorised villages for the nomadic communities in the Municipality of Rome entered into force. The regulation makes obligatory the identification of all people who enter Roma camps, both residents and occasional visitors. Residents will be provided with identification cards, with a photo and personal data. Local police forces can carry out internal and external security services and residents are allowed to stay in the camps only if they take part in activities aimed at their social and working integration. People who infringe the provisions of the regulation could be expelled within 48 hours from notification of the assessment. ${ }^{163}$ The Regulation on the areas for nomads in the Municipality of Milan entered into force during the same period and contains very similar provisions. ${ }^{164}$ In his 2009 report voicing concerns about these measures, the Council of Europe Commissioner for Human Rights stressed that the evictions of Roma "should never take place if the authorities are not in a position to make available alternative, adequate accommodation for which the persons affected should be consulted.",165

160 ECRI (2009), Fourth Report on Belgium, Strasbourg: ECRI, § 82, available at: http://hudoc.ecri.coe.int/XMLEcri/ENGLISH/Cycle 04/04_CbC_eng/BEL-CbC-IV-2009018-ENG.pdf (09.09.2009).

161 Report by the Council of Europe Commissioner for Human Rights, Thomas Hammarberg, on his visit to Belgium 15-19 December 2008. CommDH(2009)14, available at: https://wcd.coe.int $/$ ViewDoc.jsp? id=1458603\&Site=CommDH\&BackColorInternet=FEC65B \&BackColorIntranet=FEC65B\&BackColorLogged $=\mathrm{FFC} 679$.

162 CERD (2008) Consideration of reports submitted by the states parties under article 9 of the Convention, Concluding observations of the Committee on the Elimination of Racial Discrimination: Germany, 73rd Session, 28 July - 15 August 2008, available at: http://www2.ohchr.org/english/bodies/cerd/cerds73.htm (21.12.2009).

163 Commissario Delegato per l'Emergenza Nomadi nel territorio della regione Lazio, Regolamento per la gestione dei villaggi attrezzati per le comunità nomadi nella regione Lazio (18.02.2009), available at: http://www1.interno.it/mininterno/export/sites/default/it/sezioni/sala stampa/notizie/minoranz e/0670 20090219 regolamento roma villaggi nomadi.html (25.09.2009).

164 Commissario per l'Emergenza Nomadi in Lombardia (2009) Regolamento per le aree destinate ai nomadi del comune di Milano (05.02.2009), available at: http://www.interno.it/mininterno/export/sites/default/it/assets/files/16/0845_regolamento2009 0205.pdf (21.12.2009).

165 Report by Thomas Hammarberg, Commissioner for Human Rights of the Council of Europe, following his visit to Italy on 13-15 January 2009. CommDH(2009)16. Available at: 


\subsection{Racism and discrimination in the education sector}

This section examines available indicators and information on racism, discrimination and inequality in the education sphere. Several themes of particular interest are discussed regarding the policies and debates in the $27 \mathrm{EU}$ Member States, including access to education, racist incidents, discriminatory practices, and inequality in education.

\subsubsection{Access to education}

While on a legal basis EU Member States provide open access to education in practice, in reality refugees, asylum seekers, migrants and minorities face many difficulties in accessing quality education.

In Greece, the UN Committee for the Elimination of Racial Discrimination expressed in its 2009 report its concern about access problems of the Turkishspeaking minority in Western Thrace to quality education. ${ }^{166}$

In 2009, the Children's Rights Ombudsman Institution published a report on the integration in Lithuanian schools of children of foreign citizens who migrated to Lithuania. ${ }^{167}$ Many practical challenges to the integration of migrants' children in schools were noted, such as (1) lack of methodology to evaluate a student's ability, (2) insufficient preparation of teachers, and (3) in some cases, insufficient financing of Lithuanian language and other additional classes.

For Ireland it was found that certain aspects of school admission policies impact indirectly on newcomer students. ${ }^{168}$ For example, newcomer students are much less likely to fulfil certain criteria which can facilitate access to schools, such as having an older sibling in the school, having applied for a school place at an early age, ${ }^{169}$ or having a parent who attended the school.

In the UK, a report focusing on 13 local areas of England by the Institute of Community Cohesion points out that the admission process contributes to the

https://wcd.coe.int/ViewDoc.jsp?id=1428427\&Site=CommDH\&BackColorInternet=FEC65B \&BackColorIntranet=FEC65B\&BackColorLogged=FFC679

$166 \mathrm{UN} \mathrm{CERD/C/GRC/CO/19,} \mathrm{Concluding} \mathrm{observations} \mathrm{of} \mathrm{the} \mathrm{Committee} \mathrm{on} \mathrm{the} \mathrm{Elimination} \mathrm{of}$ Racial Discrimination on Greece (28.08.2009), p.5. http://www2.ohchr.org/english/bodies/cerd/docs/CERD.C.GRC.19EN.doc

167 Children's Rights Ombudsman Institution of the Republic of Lithuania (2009) Report on the Integration in Lithuanian Schools of Children of Lithuanian and Foreign Citizens, who (re)immigrated to Lithuania / 21.01.2009 No. 15-2008/KI-6.

168 ESRI; Smith, E.; Darmody, M.; McGinnity, F.; Byrne, D. (2009) Adapting to Diversity: Irish Schools and Newcomer Students; p181, available at:

http://www.esri.ie/UserFiles/publications/20090529124035/RS008.pdf (19.11.2009).

169 Many Irish national chldren have their names put down for schools at the time of their birth. 
inappropriate allocation of black and minority ethnic pupils to schools far from where they live and in areas unaccustomed to such communities and not used to operating in a diverse context. This can also be because schools which perform less well tend to have more unfilled vacancies and thus end up with students who are new arrivals and cannot get into schools nearer their home that are fully subscribed. Another reason is that new arrivals often arrive after the application deadline has closed or do not understand the process fully. ${ }^{170}$

In the last year more than a quarter of the 5,360 unaccompanied asylum seekers who arrived in the UK claiming to be children were judged to be adults, some solely on the basis of visual assessments. However, the refugee council estimates that as many as half of such decisions may be wrong. Due to this, children as young as 14 are placed in detention centres or housed with unrelated adults, without the education and care they are entitled to ${ }^{171}$ (For reference to further issues regarding unaccompanied asylum-seeking children see Section 6.1.)

Further obstacles to equal access to quality education were encountered in Finland, Latvia, and Lithuania. In Finland, the Municipality of Enontekiö had not fulfilled its statutory obligations to arrange classes in the Sámi language to all Sámi pupils. ${ }^{172}$ In Latvia, the Tukums City Council decided not to run the first grade of minority education programmes in a secondary school even though applications of parents of 15 children who requested enrolment of their children in the first grade were received. ${ }^{173}$ In Lithuania, the Equal Opportunities Ombudsperson received a complaint alleging that requirements of admission to Vilnius Šolom Aleichemo secondary school prioritise students of Jewish origin The school subsequently discarded the discriminatory requirements of admission. ${ }^{174}$

In the Czech Republic, Amnesty International documented the widespread discrimination against the Roma minority in access to public education (a high percentage of the children attend the so-called "practical" schools) as well as in housing, healthcare services or employment. ${ }^{175}$ These findings were confirmed by a survey conducted by the Ministry of Education, Youth and Sports and the Institute for Information on Education, showing that the segregation of Roma children in special schools, or schools with the educational level of former special schools, continues in 2009, despite the judgment of the ECtHR in the

\footnotetext{
170 Institute of Community Cohesion. 2009. Building community cohesion in Britain. http://resources.cohesioninstitute.org.uk/Publications/Documents/Document/DownloadDocu mentsFile aspx? recordId=108\&file=Wordversion (22.12.2009)

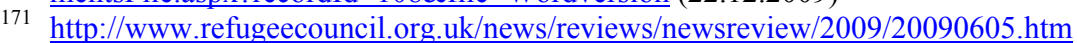

172 Finland/Syrjintälautakunta/ 17/12/2008 (11.12.2008)

173 Administratīvās rajona tiesas 2009. gada 27. maija Lēmums par atteikšanos pieņemt pieteikumu

174 The statement of the Equal Opportunities Ombudsperson to the complaint of Saulius Girgždas / No. 09-SN-69, 16.07.2009.

175 See http://www.icm.cz/lidska-prava-v-cr-chybi-ochrana-pred-diskriminaci-a-vzestupem-ex (in Czech only, 04.12.2009).
} 
case D.H. and Others v. Czech Republic on 13 November 2007. This situation prompted the Czech School Inspection to cooperate with Společně do školy ${ }^{176}$, a common project of $13 \mathrm{NGOs,} \mathrm{aimed} \mathrm{at} \mathrm{enhancing} \mathrm{equality} \mathrm{in} \mathrm{access} \mathrm{to}$ education for Roma children and disabled children. ${ }^{177}$

In the FRA EU-MIDIS survey, ten per cent of Roma respondents felt they had been discriminated against in the educational system at least once in the preceding year, either as students or as parents. For the Roma, this is a lower rate than for other domains tested, such as employment and housing. However, the discrimination rates were higher in Poland, where 20 per cent of respondents who had contact with the educational system reported unequal treatment, and in Hungary, where the figure was 17 per cent. ${ }^{178}$

\section{Efforts for fairer access to education}

In Cyprus, the Ministry of Education provided instructions to all public schools to enrol all pupils without exception, irrespective of whether their parents reside in Cyprus legally or illegally and as to whether they can present all necessary documents. This constitutes a departure from previous policy whereby schools were instructed to request migrant pupils to present the contact details of their parents, in an effort to locate irregular migrants. ${ }^{179}$

\subsubsection{Racist incidents and discriminatory practices}

Only France ${ }^{180}$ and the Netherlands ${ }^{181}$ have nationwide systems of monitoring racist incidents in education. In Germany, some Federal States monitor rightwing extremism in schools and in the UK all schools have a mandatory obligation to locally collect and keep annual records of racist incidents in schools. No other Member States have systematic monitoring of racist incidents in education currently in place.

${ }^{176} \mathrm{http}: / /$ spolecnedoskoly.cz $(12.01 .2010) ;$

more information available at $\mathrm{http}$ //www.ferovaskola.cz/aktuality/segregace-v-ceskemskolstvi-nadale-pretrvava-ukazuje-to-vyzkum-ustavu-pro-informace-ve-vzdelavani-107.html (10.10.2009).

178 FRA EU-MIDIS Main Results Report Vienna 2009, p. 45-46

179 Notification by the Ministry of Education to the Cyprus National Focal Point

180 The first results of SIVIS (Système d'Information et de Vigilance sur la Sécurité scolaire Vigilance and Information system on school Safety) were published at the end of 2008. According to the Ministry's information, violent racist, xenophobic or anti-Semitic incidents accounted for 5 per cent of the incidents listed by the public secondary schools in 2007-2008. See the Annual Report 2008 on The Fight against Racism, Anti-Semitism and Xenophobia published by the National Consultative Commission on Human Rights (Commission nationale consultative des droits de l'homme-CNCDH) in March 2009.

181 In 2008 local and regional Anti-Discrimination Agencies $(A D B S)$ registered 248 complaints in the area of education, accounting for 5.2 percent of the total number of complaints. The majority of complaints (156 complaints) concerned racist discrimination. 
Types of racist incidents and discriminatory practices reported to the FRA in 2009 include hate speech and harassment by peers, parents or teachers, in a number of Member States.

Examples of incidents reported in 2009: In Austria, pupils made anti-Semitic remarks during a visit to the former Nazi concentration camp in Auschwitz; ${ }^{182}$ in Hungary, the headmaster of a school told undisciplined children of mostly Roma origin that the paramilitary anti-Roma organisation 'Hungarian Guard' was right and 'Gypsies deserve to be smashed'; ${ }^{183}$ in Germany, a teacher at a vocational school told a student of Muslim origin that he should "go back to your Allah, Mohammed or wherever you belong", and refused to apologise; ${ }^{184}$ in Slovenia, discriminatory articles were published in school newspapers; ${ }^{185}$ and in Sweden, a case of racist harassment of two students was taken to court by the Ombudsman because the school had failed to take any action. The harassed boys received compensation. ${ }^{186}$

Discrimination on religious grounds was reported in some Member States. For example, in Luxembourg a teacher wearing visible signs of his religion reported that he felt harassed by his colleagues and the board. ${ }^{187}$ Practices likely to lead to stigmatisation of the pupils concerned were reported in Malta, where children from ethnic minorities were offered the same remedial educational support as pupils with disabilities, ${ }^{188}$ and in Italy, where three schools launched a programme called 'Water and Soap', requiring pupils from Roma families to arrive earlier than their peers and to take a bath and change clothes before entering the classroom. ${ }^{189} \mathrm{~A}$ case of language discrimination in education was reported from Bulgaria. ${ }^{190}$

\subsubsection{Inequality in education}

In many EU Member States, there is a considerable performance gap between students with a majority background and students with a migrant or minority

182 ZARA, Rassismus Report 2008, p. 45, available at http://www.zara.or.at/_doc/2009/ZARA_RassismusReport2008.pdf (11.09.2009).

183 http://www.egyenlobanasmod.hu/zanza/654-2009.pdf (22.12.2009)

184 Antidiskriminierungsnetzwerk Berlin (ADNB) (2009) Antidiskriminierungsbericht 20062008, Berlin, p. 17; available at: http://tbb-berlin.de/downloads_adnb/ADNB-

Antidiskriminierungsreport 2006-2008.pdf

185 Human Rights Ombudsman Annual Report 2009

186 Ombudsmannen mot etnisk diskriminering, Arsredovisning 2008 (Stockholm: Ombudsmannen mot etnisk diskriminering, 2008).

187 Complaint submitted to the Centre pour l'Egalité de Traitement.

${ }^{188}$ C. Calleja et al. (2009) Education of Children from Ethnic Communities in Malta Unpublished study, p. 31

189 http://www.tgcom.mediaset.it/cronaca/articoli/articolo443761.shtml (11.03.2009)

190 'Консул ходатайства за студенти', in: Дневник морски (24.02.2009), available at: http://www.dnevnik.bg/morski/2009/02/24/680611_konsul_hodataistva_za_studenti/ (10.09.2009) 
background. These performance gaps can partly be explained through school systems that do not counterbalance socioeconomic differences and differences in language knowledge. Differences in performance can also be the result of segregation in education and discriminatory practices of school authorities and within schools.

Available data also shows that migrants and minorities are in many EU Member States overrepresented in 'special needs' schools, diminishing their chance to educational and professional success. For example, in Austria, the Ministry for Education, Arts and Culture (BMUKK) highlights in its first national report on education for Austria the relevance of the socio-economic background of families for the educational achievements of pupils in Austrian schools. Pupils with migrant backgrounds are overrepresented in special schools and underrepresented in higher educational tracks. ${ }^{191}$

\subsubsection{Issues and debates concerning discrimination and exclusion in education}

\section{Segregation}

Segregation continues to be a problem in the EU. For example, the European Commission against Racism and Intolerance (ECRI) states in its 2009 report on Bulgaria that many Roma children continue to face a high early drop-out rate and language problems in school. Most of these children continue to study in practically segregated schools for various social and economic reasons. The lack of statistics on the situation of minority pupils obstructs the performance and the evaluation of different state programmes. ${ }^{192}$ In Romania, the research report "Monitoring the application of measures against school segregation in Romania"193 concluded that 67 per cent of a sample of 90 schools are segregated, and that Order no. 1540/2007 of the Minister of Education, Research and Youth ${ }^{194}$ has not been enforced in 63 per cent of a sample of 77 schools. Concrete instances of segregation in education of children with language difficulties and/or belonging to minority populations were reported in

191 See W. Specht (ed.) (2009) Nationaler Bildungsbericht Österreich 2009. Band 1. Das Schulsystem im Spiegel von Daten und Indikatoren. BMUKK/bifie. Graz: Leykam, available at: http://www.bifie.at/sites/default/files/pub-pdf/2009-06-16_NBB-Band1.pdf (10.09.2009).

192 ECRI (2009) Fourth Report on Bulgaria, Strasbourg: ECRI, $\bar{\S} 43$ available at: http://www.coe.int/t/dghl/monitoring/ecri/Country-by-country/Bulgaria/BGR-CbC-IV-2009002-ENG.pdf (29.09.2009).

193 Prepared by Laura Surdu for Romani CRISS, published in the newsletter Romania/ Învățământul pentru romi, no. 33 of 16 January 2009.

194 Order 1540/2007 rules, in Article 1, paragraph 2, that beginning with the 2007-2008 school year, 1 st and 5 th grades shall not be formed with exclusively or predominantly Roma students 
several countries, notably regarding segregation of Roma pupils in Bulgaria, Greece, Portugal ${ }^{195}$ and Hungary. ${ }^{196}$

\section{Mother-tongue education}

In Denmark, a national mapping has shown that the removal of the right to free mother-tongue teaching for bilingual children in 2002 has lead to a serious decrease in ethnic minority students' access to teaching in their mother tongue. In 2008 only 5 out of 98 municipalities were still offering mother-tongue teaching to students from third countries. ${ }^{197}$

\section{Religious symbols}

The question of permitting or prohibiting the display of religious symbols in education by pupils and/or educators has lead to recurring debates and legislative measures in the past years. Current policies range from nationwide prohibition on displaying any religious symbol in public school to complete freedom of pupils and/or teachers to wearing any religious symbol. In Belgium, in June 2009 a public Flemish school in Antwerp introduced a ban on wearing 'religious signs'. The decision raised a lot of public attention. On September 11, 2009 the central council of the Flemish public schools from the Flemish Community $^{198}$ introduced a general ban on 'religious signs' in Flanders. ${ }^{199}$ Examples of relevant legal and administrative decisions during 2009 can be found in Section 3.5.3 of this report.

\section{The image of minorities in school textbooks}

In 2009, the FRA asked its National Focal Points to survey whether textbooks used in school education are regularly checked by national or local authorities regarding their non-discriminatory content and the adequate representation of minorities. In many countries, the Ministry of Education or an expert committee under the ministry is responsible for examining the quality of textbooks used in school. However, only in a few countries are textbooks regularly and systematically checked for possible discriminatory content (see Table 3.1).

\footnotetext{
195 In Bulgaria, the gradual transition of Bulgarian pupils to another school being more 'prestigious' caused a practical segregation of the Roma children. In Greece, in spite of an ECtHR judgment in 2008. Roma children are still obliged to continue attending a school that was created uniquely for them. In Portugal, the 'Regional Board of Education of the North', approved the creation of a separate class for Roma children of different ages and qualified the practice as "positive discrimination".

196 http://www.egyenlobanasmod.hu/zanza/525-2009.pdf (29.09.2009).

197 DACoRD (2008) 'Danmark har ondt i modersmålet - kortlægning af modersmålsundervisningen i Danmark 2007/2008' www.drcenter.dk (22.12.2009)

198 These are public schools that are directly managed by the Flemish Community, as opposed to public schools run by the municipalities or the provinces.

199 Cf. website: http://www.g-o.be/go_splash/ (28.09.2009)
} 
Table 3.1: Assessment of non-discriminatory content of textbooks used in schools

\begin{tabular}{|c|c|c|c|}
\hline $\begin{array}{l}\text { Textbooks } \\
\text { regularly } \\
\text { checked by } \\
\text { authorities on } \\
\text { certain forms of } \\
\text { discrimination }\end{array}$ & $\begin{array}{l}\text { Responsibility } \\
\text { of schools to } \\
\text { ensure high } \\
\text { quality of } \\
\text { teaching } \\
\text { material }\end{array}$ & $\begin{array}{l}\text { Textbooks not } \\
\text { regularly } \\
\text { checked }\end{array}$ & $\begin{array}{l}\text { No information } \\
\text { available }\end{array}$ \\
\hline $\begin{array}{l}\text { Austria }^{200} \text {, } \\
\text { Belgium, Czech } \\
\text { Republic } \\
\text { Germany }^{202} \text {, } \\
\text { Hungary, } \\
\text { Latvia } \\
\text { Lithuania, Malta }\end{array}$ & $\begin{array}{l}\text { Denmark, } \\
\text { Finland, UK }\end{array}$ & $\begin{array}{l}\text { Bulgaria, } \\
\text { Cyprus }{ }^{204} \text {, } \\
\text { Estonia, } \\
\text { Greece, } \\
\text { Ireland, } \\
\text { Poland, } \\
\text { Portugal, } \\
\text { Romania, } \\
\text { Slovakia, } \\
\text { Spain }\end{array}$ & $\begin{array}{l}\text { France, Italy, } \\
\text { Luxembourg, } \\
\text { Netherlands, } \\
\text { Slovenia, } \\
\text { Sweden }^{205}\end{array}$ \\
\hline
\end{tabular}

\subsubsection{Support measures and good practice activities}

In 2009, governmental institutions and civil society organisations in Member States initiated a range of support measures and good practice activities in the education sector. The measures and activities included:

200 Only the equal treatment of men and women is explicitly mentioned as a point the committee of experts, installed by the Ministry of Education, should pay attention to.

201 In the Czech Republic, the Ministry of Education, Youth and Sports issues so called "permission clauses" that each course book has to fulfil in order to be used. These conditions also include the clause that: the material "respects fundamental rights and basic freedoms guaranteed to all people regardless of colour of their skin, language, faith and religion, membership in a national or ethnic minority and promotes equal opportunities for men and women”.

202 In Germany, textbooks and teaching material used in schools are only checked regarding their compliance with the Constitution, other legal provisions, the respective state school curricula and their didactic and linguistic suitability.

203 In Latvia, education material evaluation criteria envisage that educational books have to respect human rights enshrined in the Constitution of the Republic of Latvia and in other legal acts, such as the rights of the child, basic principles of racial, ethnic and gender equality. However, some studies indicate that there is a lack of education materials that would reflect ethnic, religious or linguistic diversity of Latvia. Almost 60 per cent of minority teachers feel dissatisfaction with the way minority ethnic groups are represented in school textbooks.

204 In Cyprus, the Ministry of Education expressed its commitment to revise the existing History textbooks as part of the ongoing process for the revision of the curricula at all levels.

205 The Swedish National Agency for Education conducted a review of 24 textbooks in 2006 , including a review of the representation of minority groups. 
- Intercultural teacher training and support material (Austria ${ }^{206}$, Bulgaria $^{207}$, Germany $^{208}$, Hungary $^{209}$, Latvia ${ }^{210}$, Poland ${ }^{211}$, Romania $^{212}$, Slovenia ${ }^{213}$ )

- Teacher training on and new approaches to human rights education and Holocaust education (Cyprus ${ }^{214}$, Denmark ${ }^{215}$, Germany ${ }^{216}$, Malta ${ }^{217}$ )

- Training of Roma as teaching assistants (the Netherlands ${ }^{218}$, Slovenia $^{219}$ )

- Educational and language learning support for migrants, minorities, asylum seekers, refugees, and pupils with language or learning difficulties

(Austria $^{220}$, Bulgaria ${ }^{221}$, Denmark ${ }^{222}$, Estonia ${ }^{223}$, Germany ${ }^{224}$, Hungary $^{225}$, Latvia ${ }^{226}$, Malta ${ }^{227}$, the Netherlands ${ }^{228}$ )

- Study on impact of special support measures for pupils with language or learning difficulties $\left(\right.$ Finland $^{229}$ )

- Integration projects in schools (Italy ${ }^{230}$, Spain $^{231}$, Poland $^{232}$, Spain $^{233}$ )

206 See http://pv.noe-

lak.at/fileadmin/groups/23/dokumente/Projekte/Infotext fuer Projekt IKM Volksschule09.p df (22.12.2009).

207 See http://www.nccedi.government.bg/page.php?category=104 (22.12.2009).

208 See http://www.fair-in-der-kita.de/ (22.12.2009).

209 See http://menedek.hosting1.deja.hu/node/678 (22.12.2009).

210 See http://www.lvava.gov.lv/index.php?darbibas_virzieni+projekti+skolotajs_telpa (22.12.2009).

211 See http://interwencjaprawna.pl/projekt-sc-rowne-szanse-polskiej-szkole.html (22.12.2009).

212 See http://www.per.org.ro/english/?p=37\#more-37 (22.12.2009).

213 See http://www.uvrvi.si/index.php?option=com content\&view=frontpage\&Itemid=1 (22.12.2009).

214 See http://www.medinstgenderstudies.org/?p=1871\#more-1871 (22.12.2009).

215 See http://www.amnesty.dk/undervisning/artikel/undervisning/danske-skoleelever-manglerviden-om-menneskerettigheder (22.12.2009).

216 See http://www.paedagogisches-zentrum-ffm.de/ (22.12.2009).

217 See http://www.independent.com.mt/news.asp?newsitemid=82810; http://www.voiceforall.gov.mt/ (22.12.2009).

218 http://www.srsr.nl/sinrom mei 2008.pdf (22.12.2009).

219 http://www.uvrvi.si/index.php?option=com_content\&view=frontpage\&Itemid=1 (22.12.2009).

220 See http://www.volkshilfe.at/1276,.,2.html; http://www.roma-service.at/rombus.shtml (22.12.2009).

221 See http://ec.europa.eu/ewsi/UDRW/images/items/docl_1334_22654839.pdf; (22.12.2009)http://www.az.government.bg/Projects/Prog/Activ/activ.htm (22.12.2009); http://www.nccedi.government.bg/ (22.12.2009).

222 See www.vesterborgefterskole.dk (22.12.2009).

223 See http://www.jmk.ee/index.php?language $=$ ee \&root $=5 \&$ sub $=142$ (22.12.2009).

224 See http://www.raa.de/rucksack-kita.html; http://www.stmas.bayern.de/kinderbetreuung/download/baykibig.pdf; (22.12.2009) http://www.nightingale-projekt.de/; http://www.aktion-zusammen-wachsen.de/ (22.12.2009).

225 See http://www.biztoskezdet.hu/site/doc/section/6/id/5 (22.12.2009).

${ }_{226}$ See http://www.lvava.gov.lv/index.php?darbibas_virzieni+projekti+begli2 (22.12.2009).

227 See http://www.migrantsmalta.org/projects/ (22.12.2009).

228 See http://www.minocw.nl/documenten/130626.pdf (22.12.2009).

229 See http://www.yhdenvertaisuus.fi/suomi/yesyhdenvertaisuus_etusijalle/erityisluokka_elamankulussa-sem/ (22.12.2009)

$230 \mathrm{See}$ http://www.îsmu.org/ISMU new/index.php?page=540 (22.12.2009). 
- Desegregation projects (Czech Republic ${ }^{234}$, France $^{235}$, Germany ${ }^{236}$

- Awareness raising projects on diversity and anti-discrimination (Austriaa ${ }^{237}$, Cyprus $^{238}$, France $^{239}$, Germany $^{240}$, Italy ${ }^{241}$, Malta $^{242}$ )

- Allocation of education or traineeship places for Roma (Romania ${ }^{243}$ )

It should be noted, however, that the impact of support measures and good practice activities has in many cases been a limited one. The limited outcome was due to the fact that such measures and activities were not accompanied by broader improvements of the education system as a whole. Moreover, many programmes suffer from a lack of adequate funding and in many cases there is no evaluation of effectiveness and impact of measures.

231 See http://www.pangea.org/aecgit/pdf/28jornadas/LIBROPONENCIAS.pdf; (22.12.2009)http://www.pangea.org/aecgit/pdf/27jornadas/CEIP ANDALUCIA\%20 Sevilla. pdf (22.12.2009).

232 See http://interwencjaprawna.pl/projekt sc szkola wielokulturowa2.html (22.12.2009).

233 See http://www.pangea.org/aecgit/pdf/27jornadas/CEIP ANDALUCIA\% 20 Sevilla.pdf (27.08.2009). http://www.pangea.org/aecgit/pdf/28jornadas/LIBROPONENCIAS.pdf (31.08.2009).

234 See http://spolecnedoskoly.cz/ (22.12.2009).

235 See $\mathrm{http} / / /$ i.ville.gouv.fr/divbib/doc/convcadreeducationDEC2007.pdf (22.12.2009).

${ }^{236} \mathrm{See}$ http://www.stmas.bayern.de/migration/material/auslby08.pdf (22.12.2009).

237 See http://www.roma-service.at/rombus.shtml (22.12.2009).

238 See http://www.moec.gov.cy/deltia/pdf/paideia-politismos-march2009.pdf (29.09.2009); http://www2.cytanet.com.cy/fanerom-dim/zep/html/ie aead_ooci eydni.html (29.09.2009).

239 See http://www.halde.fr/Sensibilisation-des-jeunes, $12320 . \mathrm{html}$; http://ouvertatous.skyrock.com (22.12.2009).

240 See http://www.hintertorperspektive.de/; http://www.junik-imsport.de/cms/iwebs/default.aspx (22.12.2009).

241 See www.nonaverpaura.org; (22.12.2009); http://www.emiliaromagnasociale.it/wcm/emiliaromagnasociale/home/antidiscriminazioni.ht $\underline{\mathrm{m}}(22.12 .2009)$

242 See http://www.migrantsmalta.org/test (22.12.2009).

243 Notification no. 29614 of 18 March 2009 of the Ministry of Education, Research and Innovation,, 18 March 2009; Notification no. 28268 of 2 March 2009 of the Ministry of Education, Research and Innovation; see reference at http://www.divers.ro/initiative_ro?wid=37619\&func=viewSubmission\&sid=9730 (20.09.2009). 
On the 2010 International Remembrance Day for the Victims of National Socialism, the FRA released the findings of the first ever EU-wide study on the role of historical sites and museums in teaching about the Holocaust and human rights. The research, carried out in 2009, reveals that at historical sites and in schools across the EU, teaching about the Holocaust rarely includes discussion of related human rights issues. Teachers and guides are regarded as key to ensuring interest in the subject, yet there is a lack of human rights training for both groups. Based on the findings of its study, the FRA encourages national governments to better integrate human rights education into their school curricula to reflect the significance of human rights for both the history and the future of the $\mathrm{EU}^{244}$

\footnotetext{
${ }^{244}$ FRA Discover the past for the future. A study on the role of historical sites and museums in Holocaust education and human rights education in the EU Vienna 2009
} 


\subsection{Racism and discrimination in the healthcare sector}

Article 35 of the EU Charter of Fundamental Rights guarantees access to healthcare for all. Nonetheless, there are groups of individuals who have particular problems exercising their right to healthcare, namely irregular migrants and rejected asylum seekers, and also the Roma and Travellers. In addition, there are practical obstacles in accessing healthcare services in culturally diverse populations, where language problems or a lack of culturally sensitive provision of health services may lead to cases of direct and indirect discrimination.

Collection of data on racism and discrimination in healthcare proves to be problematic, as most of the Member States do not provide data on discriminatory incidents in relation to the health sector. Scarcity of information does not allow for identifying any trends.

Overall, four main themes emerged from the RAXEN data collection in 2009, namely: access to healthcare for irregular migrants and asylum seekers; Roma health; cultural mediation; and mental health. These will be discussed in the following sections.

\subsubsection{Access to healthcare for irregular migrants and asylum seekers}

Irregular migrants should at minimum receive free access to emergency healthcare, and asylum seekers should have access to emergency health care that includes at least essential treatment of illness. However, the legislative provisions vary between Member States, and the application of these laws determines the ease with which medical care can be accessed.

There can be bureaucratic obstacles in accessing healthcare by refugees and asylum seekers, such as complex application procedures and lengthy processing times. Medical personnel can act as gatekeepers restricting the access to medical care of irregular migrants and asylum seekers. For example, as in the case of Poland, there is evidence of medical personnel's insufficient familiarity with regulations regarding foreigners' access to healthcare and their inadequate command of foreign languages. ${ }^{245} \mathrm{~A}$ report from the French CMU (providers of universal medical insurance) noted that a quarter of doctors and dentists based in Paris refuse to take care of low-income patients because of the lower prices

245 M. Bieniecki, P. Kaźmierkiewicz (2008) 'Learning to welcome: integration of immigrants in Poland', in: M. Bieniecki et al., Learning to Welcome: the integration of immigrants in Latvia and Poland, Warsaw: Institute of Public Affairs, p. 122. 
which apply to them on the basis of social insurance rules. ${ }^{246}$ Many persons in the low income category are of migrant or minority ethnic origin.

There are numerous examples reported from Italy of undocumented migrants trying to access emergency care being denounced to the police by medical staff. $^{247}$

In Italy, a 20-year-old undocumented Nigerian woman was denounced by a doctor in the emergency ward where she went for treatment. When she refused to give her contact details the doctor requested the intervention of the police to identify her, on grounds of being a "public health threat". The woman was later tried using fast-track procedures and expelled from the national territory, because she had a previous expulsion order. ${ }^{248}$

There is also a problem of a lack of awareness of the right of access to healthcare among the target group, caused by a lack of understanding of the medical system in the host country and insufficient communication skills. This problem has been documented in Denmark, ${ }^{249}$ Greece $^{250}$ and the Netherlands. ${ }^{251}$

Other issues of concern are sanitary conditions and access to medical care in detention centres. Here, two groups are particularly vulnerable, namely women (availability of pre- and post-natal care) and children. The poor living conditions of asylum-seeking minors in Greece were reported by Human Rights Watch $^{252}$ and the Council of Europe ${ }^{253}$. Similarly, the poor condition of detained

246 See http://www.cmu.fr/userdocs/Rapport\%202008.pdf (21.01.2010).

247 See, for example, B. De Fazio (2009) 'L'incubo di K. in ospedale. "Mi hanno strappato il bambino"', in: http://napoli.repubblica.it/dettaglio/lincubo-di-k-in-ospedale-mi-hannostrappato-il-bambino/1612029/2 (01.09.2009); G. Spatola (2009) 'In ospedale per il mal di denti. Espulso un senegalese', in: Corriere della Sera (09.04.2009)

248 'Medico denuncia clandestina: espulsa', in: Corriere del Veneto (13.04.2009). See also: B. De Fazio (2009) 'L'incubo di K. in ospedale. "Mi hanno strappato il bambino"', in: http:/napoli.repubblica.it/dettaglio/lincubo-di-k-in-ospedale-mi-hanno-strappato-ilbambino/1612029/2 (01.09.2009); and

G. Spatola (2009) 'In ospedale per il mal di denti. Espulso un senegalese', in: Corriere della Sera (09.04.2009).

249 Faculty of Health Sciences, Institute of Public Health, dept of Health Services Research (2009) Migrants access to healthcare by Marie Norredam. Ph.D.

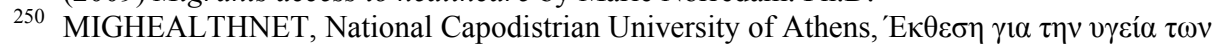

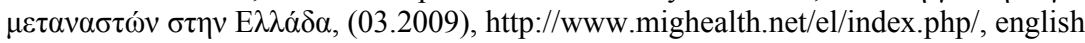
summary: http://www.mighealth.net/el/images/f/f7/Greek_State_of_the_Art_Report_English_Summary.pdf (21.01.2010). Data collected by the MIGHEALTHNET, information network on good practice in healthcare for migrants and minorities in Europe, Greek wiki, http://www.mighealth.net/el/index.php/ (21.01.2010).

251 See, for example, Pharos, (2007) Met kennis van feiten: vluchtelingen, nieuwkomers en gezondheid in cijfers. Utrecht: Pharos: Waelput, A.J.M., \& Achterberg, P.W., Etniciteit en zorg rondom zwangerschap en geboorte. (Bilthoven: RIVM, 2007); Verheusden, K., Mental health problems and barriers to service use in Dutch young adults. (Own publication, 2008).

252 Human Rights Watch, Left to Survive, 22.12.2008 http://www.hrw.org/en/reports/2008/12/22/left-survive (21.01.2010). 
migrants was reported in Malta, where according to the report published by Médecins Sans Frontières healthy detainees are placed together in cells with sick ones as a form of punishment. ${ }^{254}$

Since April 2009, the Belgian federal agency for the reception of asylum seekers 'Fedasil' has repeatedly refused the reception of children in need, who, together with their families, are living in Belgium without a residence permit. ${ }^{255}$ The Federal Ombudsman intervened without success against the refusal of Fedasil in individual cases and via general advice on two occasions in July 2009. Since beneficiaries of the national reception law have higher standards of healthcare coverage than undocumented migrants, who have only the right to receive 'urgent medical care' without charge, the Ombudsman argued that refusal of Fedasil is a violation of the UN Convention on the Rights of the Child, and in particular article 24.1 on "the highest attainable standard of health". ${ }^{256}$ The Ombudsman speaks about 'direct discrimination' ${ }^{257}$ against subjects of the national reception law: asylum seekers and undocumented migrants, who are put in a position of not being able to provide adequate care for their children.

Positive initiatives that address some of the problems identified above include:

- In the Netherlands costs pertaining to pre-natal care and delivery are fully reimbursed to the asylum seeker.

- In Slovenia asylum seekers are issued with the same social security card as the Slovenian citizens, thus facilitating access to primary care. ${ }^{258}$

The issue of access to healthcare by irregular migrants is the subject of a FRA research project undertaken in 2010. The fieldwork is conducted in 10 countries and the results will be available in 2011.

253 CommDH(2009)6, Report by Thomas Hammarberg, Commissioner for Human Rights of the Council of Europe, Human rights of asylum seekers, Strasbourg, 4.2.2009. https://wcd.coe.int/ViewDoc.jsp?id=1401927\&Site=CommDH\&BackColorInternet=FEC65B $\&$ BackColorIntranet $=$ FEC65B\&BackColorLogged $=$ FFC679 (21.01.2010)

254 Médecins Sans Frontières (2009), Not Criminals, p.11, available at: http://www.msf.org/source/countries/europe/malta/2009/2009_04_report_Malta.pdf (10.09.2009).

255 Since 2004 Fedasil is obliged to shelter undocumented underage migrants in need, which means also the sheltering of their family members.

256 Article 24.1 determines the access to health care services allowing for the enjoyment of the highest attainable standard of health and to facilities for the treatment of illness and rehabilitation of health. The enforcing of this legal right is hindered by additional practical obstacles: cf. chapter 5.1.3, point 40.

257 Federal Ombudsman, Interim Report, Third Trimester 2009, p. 1, http://www.federaalombudsman.be/sites/default/files/tussentijdsverslag fedasil.pdf, last accessed 02.10.2009;

258 UNHCR Regional Representation for Central Europe Being a Refugee: How Refugees and Asylum-seekers Experience Life in Central Europe: 2008 Report, p. 49, available at: http://www.unherbudapest.org/images/stories/news/docs/08 Reception\%20conditions/8_1_AGDM\%20report \%202008 REG/UNHCR-AGDM report 2008-ENG version-screen.pdf (30.9.2009). 


\subsubsection{Roma health}

In countries with a significant Roma and Traveller population, there have been reports of discrimination in access to healthcare for this most vulnerable of Europe's ethnic minorities ${ }^{259}$. For example, the European Committee of Social Rights found in a decision of 18 April 2009 that Bulgaria had violated Article 11 of the Revised European Social Charter in conjunction with Article E and Article 13, para.1 by failing to meet its obligations to ensure that Roma have adequate access to the health care system. ${ }^{260}$ The 2009 ECRI report describes how pregnant Roma women are placed in separate wards of inferior quality in certain maternity hospitals in Bulgaria. ${ }^{261}$ According to one interviewee, in some instances healthy women are placed alongside ill and contagious patients, leading to significant health risks for the mothers and babies. ${ }^{262}$ Discrimination by medical staff is also described with regards to the delivery of emergency care. Reportedly, ambulances in some cases refuse to enter Roma neighbourhoods or do so with a significant delay. ${ }^{263}$ There have been instances where General Practitioners refuse to examine Roma patients, or would do so only within limited hours. ${ }^{264}$

In the FRA 2009 EU-MIDIS survey, 17 per cent of Roma respondents felt that they had been discriminated against by healthcare personnel in the past 12 months, with those in Greece and Poland reporting the highest rates. North Africans on average reported the second-highest rates of discrimination, 8 per cent, but these were less than half as high as the rates experienced by the Roma. ${ }^{265}$

Furthermore, cases of involuntary sterilisation of Roma women have been reported in some Member States. In the case of Hungary, the involuntary sterilisation case handled by the United Nations Committee on the Elimination

259 According to the FRA's EU-MIDIS survey, Roma report the highest rates of discrimination as compared to other ethnic minority or migrant groupings. For more information, see: www.fra.europa.eu/eu-midis (21.01.2010).

${ }^{260}$ Council of Europe, European Committee on Social Rights (2008) Decision on the Merits, 3 December 2008, available at:

http://www.coe.int/t/dghl/monitoring/socialcharter/Complaints/CC46Merits en.pdf (18.09.2009). Also: http://www.bghelsinki.org/index.php?module=news\&lg=en\&id=2302 (12.01.2010).

261 ECRI (2009) ECRI Report on Bulgaria (fourth monitoring cycle), 24 February 2009, § 72,, available at: http://www.coe.int/t/dghl/monitoring/ecri/Country-by-country/Bulgaria/BGRCbC-IV-2009-002-ENG.pdf (29.09.2009).

262 Center for the Study of Democracy (2009) Interview with the Chair of World Without Borders (09.09.2009).

263 ECRI (2009) ECRI Report on Bulgaria (fourth monitoring cycle), 24 February 2009, § 72 , available at: http://www.coe.int/t/dghl/monitoring/ecri/Country-by-country/Bulgaria/BGRCbC-IV-2009-002-ENG.pdf (29.09.2009).

264 Center for the Study of Democracy (2009) Interview with the Chair of World Without Borders (09.09.2009).

265 FRA EU-MIDIS Main Results Report Vienna 2009, p. 44 
of Discrimination against Women (CEDAW $)^{266}$ was finally settled by the Hungarian government in 2009, resulting in financial compensation being paid to the victim. ${ }^{267}$ In a similar case, the ECtHR ruled in favour of eight Roma women suspected of being involuntarily sterilised during their stay in a hospital in Košice in Slovakia. ${ }^{268}$ In November 2009 the Czech government expressed regret over previous involuntary sterilisations of Roma women. ${ }^{269}$

\subsubsection{Cultural mediation}

Cultural mediation is an important part in the process of communication and liaison between healthcare providers and clients from minority ethnic backgrounds, as well as for non-nationals unable to speak the language of the host country. However, some countries reported problems in the availability of interpreters. What is more, some countries still do not make available general information on the healthcare system in foreign languages, for example, Germany, Malta and Poland.

Treating patients in minority languages has also proved to be problematic in Cyprus, where in some hospitals medical personnel have refused services to patients who were not able to communicate in Greek ${ }^{270}$.

Denmark has had a system of interpreters assisting non-Danish speaking patients free of charge. However, following the introduction of a law, this service will cease to exist in the future. As of 2011, persons who have lived in Denmark for more than seven years will have to pay for interpretation themselves. ${ }^{271}$

Belgium has a positive example in the area of intercultural mediation. The Federal Public Service (FPS) of Public Health, Food-Chain Security and Environment has a unit (DG1) dedicated to maintaining contact with cultural mediators who report on racial and ethnical discrimination in hospitals. According to DG1, it often is the cultural mediators who act as catalysts in reporting discrimination cases - some examples are provided below.

\footnotetext{
266 See the Data Collection Report 2007 of the Hungarian NFP p. 60.

267 'Hungary provides compensation to coercively sterilised Romani Woman', available at: http://www.errc.org/cikk.php?cikk=3011 (29.09.2009).

268 Available at: http://cmiskp.echr.coe.int/tkp197/view.asp?action=html\&documentId=849848\&portal=hbkm \&source $=$ externalbydocnumber\&table=F69A27FD8FB86142BF01C1166DEA398649 (14.09.2009).

269 http://news.bbc.co.uk/2/hi/8375960.stm

270 A. Hassapi (2009) "Learn Greek if you want medical treatment" in The Cyprus Mail (29.03.2009).

${ }^{271}$ Retsinformation: LBK nr.95 af 07/02/08, Chapter 10, § 50, stk.2: https://www.retsinformation.dk/Forms/R0710.aspx?id=114054 (21.01.2010).
} 
Interpreters and intercultural mediators in Belgium have reported the following examples of racial/ethnic discrimination in hospitals during 2009: (1) A dentist justified his refusal to collaborate with an intercultural mediator as follows: "If a Moroccan opens his trap, I can see what's missing - I don't need an interpreter for that!" (2) Employee of a hospital: "Foreigners - you don't have to give them pain killers." (3) Employee of a hospital: "These southerners with their hysterical conduct - they've got already enough (pain killers) (4) A woman of Moroccan origin suffered a cerebral haemorrhage. During transportation to the hospital by ambulance she vomited on a blanket. After arrival at the hospital, the paramedic threw the soiled blanket at the husband of the patient and cried: "Here, filthy makak!" (Flemish racist curse for people from the Maghreb). ${ }^{272}$

The Irish Health and Safety Executive has a project on Emergency Multilingual Aid (EMA) to assist frontline staff in communicating with patients with limited English proficiency attending hospitals in acute or emergency situations, covering the most common questions and terms that staff may need to ask patients in order to make an assessment of them in such situations. The EMA is available to read or download in Arabic, Bosnian, Cantonese, Chinese, Czech, French, German, Hungarian, Irish, Latvian, Lithuanian, Mandarin, Pashtu, Polish, Portuguese, Romanian, Russian, Slovak, Spanish, Somali, and Urdu. ${ }^{273}$

\subsubsection{Access to mental health services}

Data on discrimination in access to mental health services (both preventive and curative) is limited. To fill that gap in the UK, a unique census has been carried out since 2005. "Count Me In"274 is a survey of all in-patients of mental health services, including persons with learning disabilities and persons with mental health problems. Because every in-patient is included, the data collected through the project will allow for inter-group comparisons. For example, it can highlight inequalities in access and outcomes that may affect in-patients from black and minority ethnic communities, or their carers. In addition, the data from the census could show whether those from black and minority ethnic communities are more likely to be detained under the Mental Health Act, or be subject to seclusion or restraint.

\footnotetext{
272 These cases were reported by interpreters and intercultural mediators to the National Focal Point, Belgium, and confirmed by DG1 in an email of 05.10.2009.

273 A copy of the guide can be downloaded from the HSE website, and is available at: http://www.hse.ie/eng/services/news/2009_Archive/July_2009/EMA.html (25.11.2009).

274 http://www.mhac.org.uk/census (21.01.2010).
} 


\subsection{Migrant and minority issues in other areas of social life}

\subsubsection{Political participation (elections)}

EU citizenship allows all EU migrants to vote in the municipal elections of the host states they move to, as well as in the European Parliament elections. Luxembourg, for example, has eased the legal residence conditions for registration on the election lists that are applicable in this Member State by virtue of a derogation granted on the basis of the relatively high proportion of EU citizens from other Member States who reside there. At the end of 2008, the necessary number of years of residence was reduced from five to two, and the period to register reduced from 15 (European) or 18 (municipal) months to 13 weeks before elections. ${ }^{275}$

As regards third-country nationals, their right to vote in local elections is granted by only a few Member States. While this is not an area covered by EU competence, it can be argued that, on a Member State level, practices of active citizenship and measures facilitating empowerment and participation of immigrants "encourage the exercise of rights, the promotion of values and knowledge of responsibilities which foster a shared sense of belonging in a diverse society."276 With regard to participation in elections, Spain has, for instance, recently concluded agreements with certain third countries. ${ }^{277}$ Where third-country nationals are granted the right to vote, as is the case since 2004 in Belgium, ${ }^{278}$ participation of immigrant populations might still be low: for example, new research reveals that the political participation of immigrant youth in Belgium is significantly lower than of that of Belgians who are not of migrant origin, mostly due to their lower socio-economic status. ${ }^{279}$ Even in the strongly developed minority self-government system of Hungary, the 2009

\footnotetext{
275 Law of 19.12.2008,

276 See: European Commission, The consolidation of the EU framework on integration. Report to the 2010 Ministerial Conference on Integration, SEC(2010) 357 final as of 19 March 2010, at p. 6

277 So called 'Convenios de Reciprocidad' (Reciprocity Agreements) are negotiated with third countries and allow migrants from these countries to participate (to a certain degree) in Spanish electoral system. See http://www.maec.es/es/MenuPpal/Actualidad/NotasdePrensa/Paginas/15NP20090204.aspx. The agreements with Ecuador, New Zealand and Colombia entered into force on 1 January 2010.

278 Monitor, 23.04.2004, Wet tot toekenning van het actief kiesrecht bij de gemeenteraadsverkiezingen aan vreemdelingen / Lo visant à octroyer le droit de vote aux élections communales à des étrangers, http://www.bruxelleselections2006.irisnet.be/download/loi_19\%20mars_2004.pdf (25.09.2009)

279 E. Quinteller, Political Participation of Immigrant Youth in Belgium, in: Journal of Ethnic and Migration Studies, 35, 2009.
} 
ECRI Monitoring Report raises concerns over the low rate of participation of minorities in the elections. ${ }^{280}$ In its report on Bulgaria dating from the same year, ECRI is concerned that persons belonging to the Roma minority - in contrast to other minorities such as the Turks - participate little in the political process. $^{281}$

\subsubsection{Participation in public administration}

Another important facet of efficient participation in public life is the participation of persons belonging to minorities in public institutions. As regards the legislature, the UK House of Commons agreed to establish a new committee known as the Speaker's Conference. The Conference has been asked to consider and make recommendations for rectifying the disparity between the representation of women, ethnic minorities and disabled people in the House of Commons and their representation in the UK population at large. The Speakers Conference will deliver a final report with recommendations before the general election in spring 2010. In fact it seems that out of 659 MPs only 15 are from black and minority ethnic communities, and only two of these are women. ${ }^{282}$

In other Member States too the composition of official bodies does not reflect societal reality. In a 2009 report on Bulgaria, the UN Committee on the Elimination of Racial Discrimination (CERD) underlined the low representation of persons belonging to certain minority groups in various public administrations, the army and the police. The Committee recommends that Bulgaria take effective measures to improve the representation of minority groups in public services, and to prevent and combat all forms of discrimination in the selection and recruitment process in public administrations, the army and the police. ${ }^{283}$ In September 2009, the Hungarian Prime Minister announced a governmental plan to offer 200 positions to experts of Roma origin in public administration from January 2010. ${ }^{284}$ In addition, the Secretary General of the Association of European Roma Law Enforcement Officers (FAERLEO) was appointed as one of the two spokespersons for the National Police, which is an important and visible position. Positive action measures regarding Roma are consistent with the recommendation of the UN CERD that State parties to the International Convention on the Elimination of All Forms of Racial

280 ECRI (2009) ECRI Report on Hungary (fourth monitoring cycle), 24 February 2009, §§ 5356, available at: http://www.coe.int/t/dghl/monitoring/ecri/Country-bycountry/Hungary/HUN-CbC-IV-2009-003-ENG.pdf (05.10.2009), paragraphs No. 53-56.

281 ECRI (2009) ECRI Report on Bulgaria (fourth monitoring cycle), 24 February 2009, §§ 5356, available at: http://www.coe.int/t/dghl/monitoring/ecri/Country-bycountry/Bulgaria/BGR-CbC-IV-2009-002-ENG.pdf (29.09.2009).

$282 \mathrm{http} / /$ www.parliament.uk/about/how/principal/speaker/speakers_conference.cfm

283 CERD (2009) Considerations of reports submitted by States Parties under Article 9 of the Convention - Concluding observations of the Committee on the Elimination of Racial Discrimination - Bulgaria, p. 3, available at: http://www2.ohchr.org/english/bodies/cerd/docs/CERD.C.BGR.CO.19 en.doc (3.11.2009).

284 'Kétszáz roma diplomás kerülhet a közigazgatásba', available at: http://www.kormanyszovivo.hu/news/show/news 2380?lang=hu (29.09.2009). 
Discrimination "take special measures to promote the employment of Roma in the public administration and institutions, as well as in private companies. ${ }^{285}$

The issue at stake is also often addressed in the context of migrants. The UN Special Rapporteur on Racism noted vis-à-vis Germany the underrepresentation of migrants in "important institutions, including the political system, the police and the courts" and called for "positive measures to ensure the adequate representation of persons with a migration background in State institutions". ${ }^{286}$

In its Policy Programme 2007-2011, the Netherlands set out the objective that the proportion of personnel in the public sector with an ethnic minority background ('allochthonous population') should rise by 50 per cent compared to $2007 .{ }^{287}$ Furthermore, 50 per cent of the 2,000 structural trainee posts in civil services are allocated to ethnic minorities. In 2009 the Ministry of the Interior and Kingdom Relations made an agreement with the police forces concerning diversity objectives in the police and policy academy. ${ }^{288}$

In some countries, persons belonging to minorities took over prominent political positions. At the beginning of 2009, Ahmed Aboutaleb, born in Morocco, was appointed mayor of Rotterdam, the second largest city in the Netherlands. ${ }^{289}$ On 2 July 2009, Nils Usakovs was elected the Mayor of the Latvian capital Riga; he is the first ethnic Russian to hold this post. ${ }^{290}$ In October 2009, Philip Rösler who was born in Vietnam became the new German minister for health. ${ }^{291}$

\subsubsection{Issues of religious and cultural symbols}

The issue of the display of religious symbols in education has been raised earlier in Section 3.3.4. On 17 July 2009, in an important confirmation of its previous case law ${ }^{292}$, a Chamber of the ECtHR declared inadmissible the applications lodged by six pupils expelled from school in France for wearing

\footnotetext{
285 General Recommendation No. 28(2000): Discrimination against Roma.

286 United Nations (2009) press release 'UN expert on racism concludes mission to Germany (01.07.2009), available at: www2.ohchr.org/english/issues/racism/rapporteur/docs/PRelease end mission010709.pdf.

287 See http://www.regering.nl/Het kabinet/Beleidsprogramma 20072011.

288 Inspectie Openbare Orde en Veiligheid, Ministerie van Binnenlandse Zaken en Koninkrijksrelaties [Public Order and Safety Inspectorate, Ministry of the Interior and Kingdom Relations], 2009, Diversity bij de politie [Diversity of the Police]. Den Haag: IOOV.

${ }^{289} \mathrm{http} / /$ www.nytimes.com/2009/01/05/world/europe/05iht-dutch.4.19099246.html (30.09.2009)

${ }^{290}$ Elections to the European Parliament and local elections http://web.cvk.lv/pub/public/28333.html (30.09.2009); Riga City Council http://www.riga.lv/EN/Channels/Riga_Municipality/default.htm (30.09.2009)

${ }^{291} \mathrm{http://www.spiegel.de/international/germany/0,1518,658145,00.html}$

292 This was established in 2005 with the Leyla Sahin v. Turkey case
} 
conspicuous symbols of religious affiliation, regarding cases which included both the headscarf and the Sikh turban. ${ }^{293}$ Relying in particular on Article 9 (freedom of thought, conscience and religion) of the European Convention on Human Rights, taken together with Article 14 (prohibition of discrimination), the applicants complained about the ban on headwear imposed by their schools and alleged that they had been the victims of a difference in treatment based on their religion. The Court took the view that the ban on all conspicuous religious symbols in all classes of state schools was based on the constitutional principle of secularism, which was consistent with the values protected by the Convention and the Court's case-law.

In Austria, instances of discrimination based on religion are highlighted by the Equal Treatment Report 2006/2007. ${ }^{294}$ In Belgium, litigation is pending about the ban on the wearing of headscarves in certain public schools. In Germany in September 2009 the Administrative Court in Berlin ruled that the school must allow students to pray during lesson breaks once per day. ${ }^{295}$ In Finland, one of the most heavily debated issues was the decision of the Deputy Parliamentary Ombudsman that prohibition of discrimination does not prevent separate times for immigrant women being reserved at swimming baths. ${ }^{296}$ The Deputy Ombudsman referred to the Finnish Constitution and international human rights standards and argued that positive measures that intended to promote factual equality were justified in this case: the measures ensured that immigrants can receive swimming lessons and promoted their integration but were not disproportionate to the total amount of time that swimming pools were open for all users. $^{297}$

In the Netherlands, the Equal Treatment Commission (the national equality body, ETC) issued a (non-binding) opinion on 6 May 2009 about the refusal of a crèche to admit a 2 year-old child because the mother refused to take off her face-covering veil while taking her child to and from the crèche. The ETC held that the crèche was justified in its refusal, as face-covering clothes (leaving only the eyes unveiled) are being seen as an obstacle for communication and human interaction. ${ }^{298}$ Also in the Netherlands, the Central Appeals Board ('Centrale Raad van Beroep', the highest administrative court dealing with civil servants cases) ruled on 11 May 2009 that a school had a legitimate aim in demanding their teachers to shake hands irrespective of sex, as this corresponded to prevailing customs in Dutch society, and that the dismissal of a teacher for refusing to shake hands with men on the ground of her religious belief was not

\footnotetext{
293 Aktas v. France (43563/08), Bayrak v. France (14308/08), Gamaleddyn v. France (18527/08), Ghazal v. France (29134/08), J. Singh v. France (25463/08) and R. Singh v. France (27561/08).

294 Austria/Federal Ministry of Economy and Labour, Federal Ministry for Women (2009) Gleichbehandlungsbericht für die Privatwirtschaft 2007.Teil I, http://www.gleichbehandlungsanwaltschaft.at/DocView.axd?CobId=33802 (15.09.2009).

295 Verwaltungsgericht Berlin, 29.09.2009), VG 3 A 984.07.

296 Decision 16.06.2009, eoam 208/2008, Dnro 208/4/08.

${ }^{297}$ http://www.eduskunta.fi/eoaratkaisut/eoam+208/2008 (02.10.2009).

298 http://www.cgb.nl/node/14837/volledig (19.01.2010).
} 
discriminatory. ${ }^{299}$ In Sweden, in February 2010, a court overturned the decision of the National Labour Market Board which had cancelled a Muslim man's unemployment benefit on the grounds that he did not shake hands with a woman CEO at a job interview, even though this had not been the reason that he was not offered the job. ${ }^{300}$

Different examples across Europe seem to indicate that, in the context of Muslim communities, the political climate is often dominated by fears which can be played upon by politicians. Issues raised include whether or not to allow the wearing of a headscarf at school or at work, or the prohibition of Muslim students praying during lesson breaks (see Section 3.1.6 and 3.3.4 of this report). In Denmark, for example, some politicians have argued in favour of introducing a parliamentary bill forbidding public servants from wearing the headscarf at work. $^{301}$ Heated debates have also been generated in some countries over the building of mosques or minarets. For example, in Austria, authorities amended their planning laws in order to prevent buildings that might raise concerns in the population. ${ }^{302}$ In Denmark there were calls to put the planned construction of a mosque to a referendum, in the context of a highly xenophobic political debate. ${ }^{303}$ In Italy the political party "Northern League" (Lega Nord), member of the governing coalition, made the question of places of worship for Muslims a major issue in its political agenda, in a way that raised concerns by the Commissioner for Human Rights of the Council of Europe about hate speech. ${ }^{304}$ Also in Spain objections raised by the non-Muslim population against the opening of new mosques or other sorts of Islamic institutions were regularly discussed. ${ }^{305}$ In Hungary the planned opening of a Muslim cultural centre in Budapest provoked civil protest, supported by some local politicians. ${ }^{306}$

299 http://zoeken.rechtspraak.nl/resultpage.aspx?snelzoeken=true\&searchtype=ljn\&ljn= BI2440\&u ljn=BI2440 (22.10.2009).

300 http://www.stockholmnews.com/more.aspx?nid=4787\#

301 The Fag og Arbejde trade union, which organises many public sector employees, rejected this position as unacceptable.

302 In Austria the provinces of Vorarlberg and Kärnten amended their respective laws. See Raumplanungsgesetz, Vorarlberg/LGB1 39/1996, last amended by LGB1 35/2008, 19.06.2008, and Baugesetz, Vorarlberg/LGBl 52/2001, last amended by LGBl 34/2008, 19.06.2008.

303 See for Denmark the advertisement (2009) in 24 timer p. 18, 09.09.09.

304 Council of Europe - Commissioner for Human Rights (2009) Report by Thomas Hammarberg Commissioner for Human Rights of the Council of Europe, following his visit to Italy on 1315 January 2009, Strasbourg, 16th April 2009. p.6, paragraph 19.

305 At least for Catalonia the situation might be clarified through a recently passed law that has been considered as a pioneer initiative in Spain. Catalunya/Llei 16/2009 dels centres de culte (22.07.2009), available at: http://www.parlament.cat/web/activitat-parlamentaria/lleis (23.09.2009).

306 'Arab negyedtől tartanak Sas-Hegyen', in: Népszabadság (26.06.2009.), available at: http://nol.hu/arab_negyedtol_tartanak_sashegyen (18.07.2009); 'Nyílt levél Molnárnak és Kuppernek az Iszlám Központról' in: Népszabadság (29.06.2009.), available at: http://abszurdisztan.nolblog.hu/archives/2009/06/29/Nyilt_level_Molnarnak_es_Kuppernek_a z Iszlam_Kozpontrol/ (29.09.2009). 


\subsubsection{Minority languages and language barriers}

\section{The use of languages spoken by minorities}

The European Commission, as well as the Parliament, has underlined on various occasions the importance of minority languages. "Multilingual people are a precious asset because they act as the glue between different cultures". 307 At the same time, the EU does not have the legal competence to regulate on the use of language at national level. EU law does not prohibit the adoption of a policy for the protection and promotion of a specific (national) language. ${ }^{308}$ On 30 June 2009, the National Council of the Slovak Republic amended the Act on the State Language of the Slovak Republic. The move met with criticism from Hungarians in the Slovak Republic as well as by the Republic of Hungary. The OSCE High Commissioner on National Minorities noted that, while pursuing a legitimate aim, some elements of the law "raise or - depending on the implementation - might raise issues of compatibility with international standards and with the constitutional principles of the Slovak Republic". 309 Taking into account advice by the Commissioner, the Government of Slovakia adopted principles for the implementation of the amended State Language Act. The Commissioner welcomed these principles that are in force from 1 January 2010 and underlined that it is "essential that steps taken to promote the State Language do not undermine linguistic rights of persons belonging to national minorities". Moreover, the Commissioner advised that "the respect of principles of non-discrimination and proportionality and should thus safeguard the right of persons belonging to national minorities to use their mother tongue in the private and public sphere". He stressed that it is important that the government closely monitors and evaluates the implementation of the State Language Law, "particularly with regard to the imposition of fines in order to avoid undue limitations to the use of minority languages". The Commissioner finally announced that he would "remain engaged with this and other matters until the balance between strengthening the State language and protecting minority rights is achieved. $"$ "310

307 See Multilingualism: an asset for Europe and a shared commitment, $\operatorname{COM}(2008) 566$ final, at p. 6.

308 However, the implementation of such a policy "must not encroach upon a fundamental freedom such as that of the free movement of workers. Therefore, the requirements deriving from measures intended to implement such a policy must not in any circumstance be disproportionate in relation to the aim pursued, and the manner in which they are applied must not bring about discrimination against nationals of other member states". See ECJ, case C379/87, Groener, judgement of 28 November 1989, at Para. 19, available online at http://curia.eu.int/en/content/juris/index form.htm.

309 OSCE (2009) Opinion of the OSCE High Commissioner on National Minorities on amendments to the 'Law on the State Language of the Slovak Republic'; available at: http://www.foreign.gov.sk/ (22.09.2009).

310 See the High Commissioner statement on on Slovakia's language law as of 4 January 2010, available online at http://www.osce.org/hcnm/item_1_42279.html. 
In fact earlier the Commissioner had expressed the concern that the overlap of minority-related provisions in different pieces of legislation can lead to different interpretations, which might again have a negative impact on the overall legal position of national minorities in Slovakia. In this sense an undefined parallelism of a Law on Ethnic Minorities and a Law on the state language can work to the detriment of the minorities. This happened for instance in Lithuania. In 2009, two cases of dispute between local governments and the state over street names in minority languages were taken to the Supreme Administrative Court. In both cases, the court upheld the requirement of the county governor to remove street signs in the minority language. ${ }^{311}$

In Sweden a new Act on National Minorities and National Minority Languages expanded the administrative areas for Sami and Finnish. This gives more individuals the right to use Sami and Finnish in their dealings with the authorities and also the right to pre-school and care of the elderly, partly or completely in the minority language. ${ }^{312}$ Also in Poland there have been developments increasing minority language rights, especially with the introduction of minority language as the ancillary language in government offices. Poland's 2009 ratification of the Council of Europe's European Charter for Regional or Minority Languages (ECMRL) further exemplifies this trend. ${ }^{313}$ In Cyprus in autumn 2008 a Committee of experts on Cypriot Maronite Arabic has been set up to advise the government on language issues. Also a Cypriot Maronite Arabic revitalisation group was created. However, the team of experts lacks financial resources - a fact noted also in the 2009 report of the Committee of experts under the ECRML. ${ }^{314}$

\section{Language barriers and employment}

In 2009, there were a series of complaints that unreasonable language barriers were restricting access to employment for both EU citizens and third country nationals.

311 Lithuania/Lietuvos vyriausiasis administracinis teismas/ No. A-261-997/2009; Lithuania/Lietuvos vyriausiasis administracinis teismas/ No. A-756-152/2009.

312 The new legislation, the Swedish Code of Statutes 2009:724, entered into force on January 1 2010, The administrative area for Finnish is expanded to an additional 18 municipalities and the administrative area for Sami is expanded to an additional 13 municipalities. The administrative area for Meänkieli is not expanded.

313 European Charter for Regional or Minority Languages became effective in Poland as of 1 June 2009 (the Charter was signed in 2003 and ratified in January 2009). Pursuant to Charter art. 3 paragraph 1, Poland recognises the following as minority languages under the Charter: Byelorussian, Czech, Hebrew, Yiddish, Karamaic, Kashubian, Lithuanian, Lemko, German, Armenian, Roma, Russian, Slovak, Tatar, and Ukrainian. See Ministry of Interior and Administration website: http://www.mswia.gov.pl/portal/pl/584/Europejska karta jezykow regionalnych lub mniejs zosciowych.html (18.09.2009).

314 Report of the Committee of Experts on the Application of the European Charter for Regional or Minority Languages in Cyprus of 23.09.2009. 
In Cyprus there were several complaints about unnecessary demands for knowledge of the Greek language which restricted access to employment as an estate agent, 315 in a tourist office, 316 or in the nursing profession. ${ }^{317}$ Also in Denmark $^{318}$ and Sweden ${ }^{319}$ there were cases before equality bodies of complaints of discrimination on the ground of language.

An Amnesty International report criticised what it saw as the discriminatory requirements of the Estonian Language Act which means that public sector workers from minority groups faced regular monitoring of their Estonian language proficiency by the state Language Inspectorate. In June, the government introduced new language requirements for some professions in the private sector. ${ }^{320}$ Similarly in Latvia, access to the labour market for non-native speakers of the Latvian language, including citizens of Latvia, is affected by formal language proficiency requirements introduced in 2009 for various professions and occupations in public and private employment. ${ }^{321}$ In Lithuania 42 per cent of ethnic minority survey respondents indicated that they were experiencing problems in the labour market due to poor Lithuanian language skills. $^{322}$

In Germany, the labour court in Berlin sentenced an art institute to pay compensation to a 48-year old German woman, born in the Dominican Republic, for rejecting her job application on the grounds that German was not her mother tongue. The court regarded this as a case of indirect discrimination on the grounds of ethnic origin without objective justification. ${ }^{323}$

The Belgium CEOOR regularly receives complaints regarding alleged discrimination on grounds of language, although its remit does not cover cases of discrimination on the grounds of language. According to the Belgian

315 File No. AKR 70/2005 \& 73/2005, dated 23.02.2007.

316 Decision dated 01.08.2006. The Cypriot Equality body concluded that it cannot make any concrete recommendations, because there are third party rights involved (referring to the person hired for the post in question) and because an appeal is in progress before the Supreme Court, filed by the complainant, seeking to cancel the University's decision to select the other applicant.

317 Information provided by an officer of the Cypriot Equality body ON 26.09.2009.

318 Ligebehandlingsnævnet (2009) 'Ligebehandlingsnævnets udtalelse j.nr. 2500044-09 afgivet den 6. marts 2009'

http://www.ast.dk/page pic/pdf/2500044 09 sprog $15 \quad 04 \quad 2009 \quad 10 \quad 12 . p d f(01.10 .2009)$.

319 http://www.do.se/Om-DO/Stamningar-och-forlikningar/Forlikning-Jonkopings-kommun/ (21.01.2010).

320 Amnesty International, Report 2009: The State of the World's Human Rights: Estonia; available at: http://www.amnesty.org/en/region/estonia/report-2009 (01.09.2009).

321 http://www.likumi.lv/doc.php?id=194735

322 Darbo ir socialinių tyrimų institutas (2008) Vyru ir moteru, priklausančiu etninèms mažumoms, padetis darbo rinkoje, tyrimo ataskaita. Report of the study conducted by the request of the Department of National Minorities and Lithuanians Living Abroad. Available in Lithuanian at http://www.tmid.lt/wp-content/uploads/2009/05/tautmaz ataskaita-2008-125d.pdf (01.09.2009).

323 See also RAXEN Bulletin I 2009; Berlin/Arbeitsgericht/55 Ca 16952/08 (11.02.2009). 
Constitution $^{324}$, employers may regulate the use of language of their workers during work hours, even for informal communication. In 2009 the Council of Europe urged Belgium to create a body authorised to address language-based discrimination. ${ }^{325}$

\subsubsection{Negative discourse on minorities, including during elections}

Some of the campaigns for the European elections showed anti-minority elements. For instance in Hungary the Jobbik Magyarországért Mozgalom [Jobbik Movement for Hungary], continued using its slogan "Hungary belongs to the Hungarians" despite the fact that the National Election Committee had banned the slogan. ${ }^{326}$ In the UK the British National Party led a campaign "British Jobs for British Workers" which advocated that jobs in the UK should not be given to immigrants. They also supported protests and strikes at an oil refinery in Killingsholme which employed workers from other European countries. ${ }^{327}$ In Romania Jurnalul Național, the most widely read quality daily newspaper, started an anti-Roma, highly populist media campaign, including the proposal to change the name Roma to Gypsy so it would not longer be confused with Romanian outside the borders. ${ }^{328}$ Even in Greece where, despite the volume of migration inflows, migration is traditionally not exploited in election campaigns, the issue of irregular migration gained major attention by national and local media during the election campaign. In Germany during the state elections in Saxony in August 2009 and the federal elections in late September the "Nationaldemokratische Partei Deutschland" (NPD) issued slogans such as "jobs for Germans" or "criminal foreigners out", directed largely against Polish EU citizens. ${ }^{329}$ Posters that read "stop the Polish invasion!" were declared illegal. ${ }^{330}$ Finally in Sweden the "Swedish Democrats" (SD) published posters reading "Give Sweden back to us" [Ge oss Sverige tillbaka]. The party argued that a multicultural society and the EU are the greatest threats to the "unique Swedish culture". 331 After the elections, the

\footnotetext{
324 Article 129, § 1,3.

325 Cf. ECRI Report on Belgium (fourth monitoring cycle), published on 26 May 2009, p. 20, http://hudoc.ecri.coe.int/XMLEcri/ENGLISH/Cycle 04/04 CbC eng/BEL-CbC-IV-2009018-ENG.pdf, last accessed 07.09.2009

326 Hungary/Resolution No. 189/2009 of the National Election Committee, available at: http://www.valasztas.hu/hu/ovb/hatarozatok/2009/2009-2475.html (29.09.2009).

327 http://www.dailymail.co.uk/news/article-1131708/British-jobs-British-workers-Wildcatstrikes-spread-foreign-workers-shipped-UK.html (26.01.2010).

328 The newspaper is Jurnalul Naţional.

329 Compare L. Y. Roloff (2009) 'NPD-Plakatwelle macht Polen und Deutsche wütend', in. Spiegel online (21.08.2009), available at: http://www.spiegel.de/politik/deutschland/0,1518,643760,00.html.

330 Oberverwaltungsgericht Greifswald, 3 M 155/09 (19.09.2009)). Frankfurter Rundschau (29.09.2009), p. 3

331 http://www.sverigedemokraterna.net/int_text.php?action=fullnews\&id=225 (13.07.2009).
} 
leader of SD expressed in an article the view that Islam represents the country's "greatest external threat since World War II". ${ }^{332}$

\subsubsection{Roma and the recognition of marriage}

The problem of discrimination against the Roma has been referred to in various places in this report. Discrimination against the Roma in Greece was detailed in 2009 by the National Committee for Human Rights, ${ }^{333}$ and in Spain, the Roma Secretariat Foundation presented in July 2009 a report on the discrimination faced specifically by Roma women. ${ }^{334}$ Also, a judgement adopted on 8 December 2009 by the ECtHR held that Spain had violated Article 14 (prohibition of discrimination) of the European Convention on Human Rights in conjunction with Article 1 of Protocol 1 to the Convention (right to peaceful enjoyment of possessions) in the case of Muñoz Díaz v Spain. ${ }^{335}$ The case concerned the refusal by the Spanish authorities to recognise a marriage performed in accordance with Roma traditions and customs for the purposes of obtaining a survivor's pension under the General Social Security Act. The ECtHR found that the State's refusal to recognise the marriage on the basis of the good faith of the applicant was at odds with its recognition of marriage for the purpose of survivor pensions in other cases and that this constituted discriminatory treatment within the meaning of Article 14.

\subsubsection{A diversity approach to minorities}

In Belgium, in April 2009, the Flemish Parliament adopted the "Integratiedecreet" [decree on integration], ${ }^{336}$ which fundamentally alters the "Minderhedendecreet" [minorities decree] of April 1998. ${ }^{337}$ The new decree represents a shift of focus in policy from an approach based on a distinction between (non-Western) foreigners on the one hand, and native Belgians and Western foreigners on the other, to a broader approach, in which the whole Flemish society has a responsibility to promote diversity. The new decree aims at improving the efficiency, coordination and efficacy of the Flemish policy. A special role is foreseen for the Minorities Forum, a platform representing cultural and ethnic minorities in Flanders, which will be actively involved in the policy choices of the Flemish administration. Also, cities and towns will have more room to adopt an integration approach adapted to the specific situation in

\footnotetext{
${ }_{333}^{332}$ http://www.thelocal.se/22762/20091020/ (21.01.2010).

http://www.nchr.gr/media/gnwmateuseis eeda/roma/Apofasi EEDA Tsigganoi 2009 FINA L.doc (12.01.2010).

334 http://www.gitanos.org/upload/29/24/ONU-Report_Spain44_sp.pdf (01.10.2009).

335 Application no. 49151/07.

336 Flanders/Decree, $B S$ 02.VII.2009 (30.04.2009). For the full text see: $\mathrm{http}: / /$ www.ejustice.just.fgov.be/cgi/article body.pl?language $=$ nl\&caller=summary\&pub date $=2009-07-02 \&$ numac $=2009035504$ (Dutch) (24.11.2009).

337 Flanders/Decree, $B S$ 19.VI.1998 (22.04.1998).
} 
European Union Agency for Fundamental Rights Annual Report 2010

their community. There is also a structural improvement in the organisation of social translation services. 


\section{Equality and anti-discrimination}

This chapter touches upon issues of equality and anti-discrimination which have not been covered in the previous sections of this report, including developments regarding discrimination based on sex, disability, age and sexual orientation.

\subsection{Discrimination on grounds of sexual orientation and gender identity}

In 2009, the FRA published two reports on discrimination on grounds of sexual orientation in the EU Member States, one looking at the legal situation, identifying national differences in the strength of protection against discrimination for lesbian, gay, bisexual and transgender (LGBT) people, ${ }^{338}$ and the second concerning social aspects regarding rights and protection against discrimination, setting out the ways that LGBT people experience discrimination, and how it affects their lives. ${ }^{339}$

\section{Marriage and partnership recognition}

Developments in this area at national level in 2009 concern mainly the issue of marriage and partnership recognition. One Member State, Sweden, passed new legislation concerning marriage. Since 1 May 2009 the provisions of the Marriage Code are applied in the same manner regardless of whether the spouses are of different sexes or the same. The rules apply both for civil marriages and church marriages. As the new Marriage Code came into force the Registered Partnership Act ceased to apply. ${ }^{340}$ Austria adopted the eingetragene Partnerschaft-Gesetz [Act on Registered Partnership] on 10 December 2009, thereby granting same-sex couples the possibility of registering their committed union and gaining access to many of the benefits of different-sex marriage. Furthermore, in Slovenia the Constitutional Court ruled that Article 22 of the Registration of the Same-Sex Civil Partnership Act is unconstitutional and must be amended, because it created a difference in treatment between same-sex couples (united by civil partnership) and oppositesex couples (united by marriage) as regards the ability to inherit the property of the deceased partner. ${ }^{341}$ While these developments need to be seen in the context of national competences, they nevertheless have clear repercussions on employment-related benefits, as well as on the possibility to enjoy rights

\footnotetext{
338 http://fra.europa.eu/fraWebsite/products/publications reports/pub cr homophobia 0608 en.htm

339 http://fra.europa.eu/fraWebsite/products/publications_reports/pub cr_homophobia p2 0309 en.htm

$340 \mathrm{http}: / / w w w . r f s l . s e / ? \mathrm{p}=420 \quad(04.07 .2009), \quad \mathrm{http} / / \mathrm{www} . \mathrm{sweden} . \mathrm{gov} . \mathrm{se} / \mathrm{sb} / \mathrm{d} / 8586 / \mathrm{a} / 79062$ (Äktenskap för par med samma kön - Vigselfrågor (SOU 2007:17)) (04.07.2009).

341 Slovenia/Constitutional Court U-I-425/06, 02.07.2009.
} 
conferred by EU law upon 'spouses' or 'family members' (for instance in free movement cases).

In Italy, in decision No. 6441 of 17 March 2009, the Italian Supreme Court ruled for the first time that a non-EU national who lives permanently with his Italian same-sex partner is not eligible for the residence permit on the ground of family reunification. This confirms the same situation as for different-sex unmarried partners, but also highlights a potential instance of indirect discrimination on grounds of sexual orientation. In Romania, the new Civil Code expressly prohibits in Art. 277 same-sex partnerships and marriages and the recognition of same-sex marriages and partnerships registered abroad by Romanians as well as by foreigners; according to this new text, nor shall samesex or opposite-sex civil partnerships registered or contracted abroad by Romanian citizens or foreigners be recognised in Romania. ${ }^{342}$ These developments yet again illustrate the difficulties faced by same-sex partners in being treated as family members under current law and practice at both Member State and EU level.

\section{Homophobic crimes}

In Italy in 2009, an attempt to introduce an aggravating circumstance for crimes motivated by hate against LGBT people was defeated in Parliament on the ground that it would violate the equality clause of the Constitution. ${ }^{343}$ On the other hand, in June 2009, Scotland passed legislation that requires the aggravation of an offence by prejudice on the grounds of sexual orientation or transgender identity to be taken into account in sentencing, which is the first European provision specifically tackling transgender hate crimes. ${ }^{344}$ Such legislation might contribute to reducing homophobic speech and violence.

\section{Access to information on homosexuality}

In Lithuania the discussions within the Parliament of the new version of the Law on the Protection of Minors against the Detrimental Effect of certain Public Information were reportedly characterised by homophobic statements. ${ }^{345}$ Article 4 of the Law lists, among the information that causes physical, mental or moral detriment to the development of minors, information which "propagates homosexual, bisexual, polygamous relations". In September 2009, the European

\footnotetext{
$342 \mathrm{http}: / /$ www.cdep.ro/pls/proiecte/upl pck.proiect?cam=2\&idp=10256 (29.09.2009).

${ }^{343}$ Joint Bills no. 1658-1882-A have been defeated by a vote of the Lower Chamber on 13 October 2009. The Chamber concluded that the bills would be unconstitutional to the extent that victims of homophobic crimes would receive "privileged protection" with respect to other victims. [Testo unificato delle proposte di legge n. 1658 e 1882, recante l'introduzione nel codice penale della circostanza aggravante inerente all'orientamento o alla discriminazione sessuale].

344 Offences (Aggravation by Prejudice) (Scotland) Act 2009. The Bill for this Act of the Scottish Parliament was passed by the Parliament on 3 June 2009 and received Royal Assent on 8 July 2009. It came into force on 24 March 2010.

345 http://www3.1rs.1t/pls/inter3/dokpaieska.showdoc_1?p_id=349306\&p query=\&p tr2= (12.01.2010).
} 
Parliament adopted a "Resolution on the Lithuanian law on the protection of minors against the detrimental effects of public information", where it reaffirms the importance of the EU fighting against all forms of discrimination, and in particular discrimination based on sexual orientation. ${ }^{346}$ In December 2009, the Lithuanian Parliament amended the law. The new provision prohibiting agitation of homosexual relations was substituted with the neutral prohibition forbidding information which "promotes sexual relations". This wording makes it difficult to predict what the concrete application of the law will be, particularly regarding its impact on LGBT issues. The former provision prohibiting information that "undermines family values" was broadened to include information "which expresses contempt for family values, encourages the concept of entry into a marriage and creation of a family other than that stipulated in the Constitution of the Republic of Lithuania and the Civil Code of the Republic of Lithuania".

Additional bills supplementing the Penal Code and Code of Administrative Offences were proposed in 2009 to the Lithuanian parliament, which, if adopted, would permit the prosecution of a wide variety of activities. Such activities would include campaigning on human rights issues relating to sexual orientation and gender identity, providing sexual health information to LGBT people or the organisation of gay film festivals and pride events.

\section{Gender identity and recognition}

As from 1 January 2009, the new Swedish Discrimination Act forbids discrimination on grounds of "transgender identity or expression". In the EU, the only other Member States that have clear provisions on gender identity discrimination are Hungary and the United Kingdom. In several Member States, the legal uncertainty in the definition of the grounds protected by equal treatment legislation regrettably translates into a lack of effective protection. This is especially true when gender identity is not deemed to be covered by the 'sex' ground as it should be according to EU case law and the 2006 Gender Recast Directive. $^{347}$

In a judgment by the Austrian Constitutional Court in $2009,{ }^{348}$ as well as a series of judgments between 2008 and 2010 by Austria's Administrative Supreme Court, ${ }^{349}$ the possibility for having official recognition is ensured without complete gender reassignment and in particular without mandatory surgery. The only decisive factors are that the applicant is transsexual and that

\footnotetext{
346 European Parliament resolution of 17 September 2009 on the Lithuanian Law on the Protection of Minors against the Detrimental Effects of Public Information, available at http://www.europarl.europa.eu/sides/getDoc.do?pubRef=-//EP//TEXT+TA+P7-TA-20090019+0+DOC+XML+V0//EN (19.01.2010).

347 OJ L204, Volume 49, available at: http://eurlex.europa.eu/JOHtml.do?uri=OJ:L:2006:204:SOM:en:HTML.

348 VfGH 03.12.2009, B 1973/08.

349 VwGH 27.02.2009, 2008/17/0054; VwGH 15.09.2009, 2008/06/0032; VwGH 17.02.2010, 2009/17/0263.
} 
he or she has been living and working as belonging to the opposite gender. This is similar to the position in the UK, where there is no requirement to undergo hormonal treatment or surgery of any kind in order to obtain a Gender Recognition Certificate, and in Spain, where official rectification of the sex registered at birth, while requiring medical treatment, does not require that this includes gender reassignment surgery.

\subsection{Discrimination on grounds of disability}

In Germany, the Bericht der Bundesregierung zur Lage behinderter Menschen (Report on the Situation of Persons with disabilities) submitted by the German federal government, highlighted progress in the inclusive education of children with disabilities, in the employment rates of persons with disabilities, and in the creation of more accessible environment. ${ }^{350}$ At EU level, the Report of the adhoc expert group on the transition from institutional to community-based care for the elderly, children, and persons with disabilities or mental health problems was published in October 2009. The report ends with a number of recommendations, including requesting the FRA to collect data and carry out research and analysis on this issue within the framework of its mandate. ${ }^{351}$

The area of fundamental rights of persons with mental health problems and persons with intellectual disabilities constitutes one of the FRA research projects during the years 2009-2011.

\subsubsection{Convention on the rights of persons with disabilities}

The Convention on the Rights of Persons with Disabilities (CRPD) was adopted by UN General Assembly resolution 61/106 of 13 December 2006, and it came into force on 3 May 2008. At the end of 2009, it had been ratified by $12 \mathrm{EU}$ Member States: Austria, Belgium, Czech Republic, Denmark, Germany, Hungary, Italy, Portugal, Slovenia, Spain, Sweden, and the UK, and in 2010 it was ratified by three more: France, Latvia and Slovakia. The CRPD is the first international human rights treaty to which the European Union will become a party ${ }^{352}$, following the decisions adopted on 26 November 2009 by the Council of the EU allowing the European Community (now the EU) to approve the CRPD, although with a reservation to exclude the employment of persons with disabilities in the armed forces from the scope of the Convention in order to avoid incompatibility with Directive 2000/78. By becoming a party to the CRPD, the EU accepts a duty to comply with the requirements of the

\footnotetext{
350 Germany/Bundesregierung, Disability Report 2009, http://www.bmas.de/portal/9828/ (22.10.2009).

$351 \mathrm{http}: /$ ec.europa.eu/social/main.jsp?catId=429\&langId=en\&moreDocuments=yes (12.010.2010).

352 See Art. 44 of the CRPD, referring to accession by regional integration organisations.
} 
Convention in the measures it adopts, but also to take the measures required under the Convention to the extent that it has been attributed the competences necessary to that effect.

At Member State level, a number of legislative initiatives were taken in order to comply with the Convention on the Rights of Persons with Disabilities (CRPD). In some cases, such legislative initiatives were linked to the adoption of a National Action Plan to facilitate the implementation of the Convention across different branches of government, as is envisaged in Germany. ${ }^{353}$

\subsubsection{Defining disability}

An interesting development concerns the definition of 'disability' for the purpose of determining the scope of anti-discrimination legislation. In its interpretation of the Employment Equality Directive (2000/78), the European Court of Justice understands the concept of 'disability' as referring to "a limitation which results in particular from physical, mental or psychological impairments and which hinders the participation of the person concerned in professional life". ${ }^{354}$ In the Chacón Navas case, the Court explicitly distinguished 'disability' from 'sickness', implying that short-term or temporary illnesses impairing judgment are not to be considered as an 'impairment' which, in certain environments, leads to an 'intellectual disability'. Yet, in the landmark case of SCA Packaging Ltd $v$ Boyle ${ }^{355}$ the UK House of Lords extended the scope of the term 'disability' so that more people now fall within the protection of the Disability Discrimination Act 1995 (UK). ${ }^{356}$ The House of Lords in that case found that people with a physical or mental condition which varied in its severity over time should still be termed 'disabled' if it was likely their condition would become substantial again in the future.

\subsubsection{Progress with proposal for a 'horizontal' directive}

The European Commission proposed on 2 July 2008 a new directive against discrimination outside employment on grounds of religion or belief, disability, age and sexual orientation ${ }^{357}$. A 'progress report' on the proposed Directive was discussed at the Employment, Social Policy, Health and Consumer Affairs Council (EPSCO) on 8 and 9 June 2009. In its meeting of 30 November 2009, the Employment, Social Policy, Health and Consumer Affairs Council reviewed the state of play in the discussions and noted that some progress had been made

\footnotetext{
353 http://www.institut-fuer-menschenrechte.de/de/menschenrechtsinstrumente/vereintenationen/menschenrechtsabkommen/behindertenrechtskonvention-crpd.html\#c1903 (22.10.2009).

354 ECJ (Grand Chamber), 11 July 2006, C-13/05, Sonia Chacón Navas v Eurest Colectividades SA.

355 [2009] UKHL 37.

356 Available at: http://www.bailii.org/uk/cases/UKHL/2009/37.pdf (19.10.2009).

$357 \operatorname{COM}(2008) 426$.
} 
under the Swedish presidency. However, it noted that extensive work was still required so as to guarantee legal certainty and ensure that the consequences of the draft Directive were fully understood. No agreement has yet been reached on this instrument.

\subsection{Developments on equality}

\subsubsection{Commission communication on health inequalities}

In October 2009, the European Commission issued a Communication entitled Solidarity in Health: Reducing Health Inequalities in the EU. ${ }^{358}$ The term 'health inequalities' refers to differences in health status and health outcomes that are due to avoidable social and economic factors rather than individual and genetic features. A social gradient in health is established in all European countries, meaning that the poorest people live the shortest lives with the worst health. Typically, individuals belonging to migrant or Roma populations would have lower life expectancy and higher morbidity compared with the national average. Social determinants of health include access to employment, education, housing, health and social care. Therefore, provision of these services in a non-discriminatory and inclusive way would improve a population's health and decrease health inequalities.

In its Communication, the Commission refers to the role of the FRA as follows: "Examine how the Fundamental Rights Agency could, within the limits of its mandate, collect information on the extent to which vulnerable groups may suffer from health inequalities in the EU, particularly in terms of access to adequate healthcare, social and housing assistance." ${ }^{359}$

\subsubsection{Strengthening legislation}

In 2009 there were various initiatives aimed to transpose into national law the existing EU directives implementing the principle of equal treatment, in particular the Racial Equality Directive, the Employment Equality Directive, ${ }^{360}$ Council Directive 2004/113/EC of 13 December 2004 implementing the principle of equal treatment between men and women in the access to and supply of goods and services, ${ }^{361}$ and Directive 2006/54/EC of the European Parliament and of the Council of 5 July 2006 on the implementation of the

\footnotetext{
${ }^{358}$ COM(2009) 567 final, Brussels, 20.10.2009.

http://ec.europa.eu/health/ph_determinants/socio_economics/documents/com2009_en.pdf

$359 \mathrm{COM}(2009) 567$ final, Brussels, 20.10.2009, p. 8.

${ }^{360}$ Council Directive 2000/78/EC of 27 November 2000, establishing a general framework for equal treatmet in employment and occupation (OJ L 303 of 02.12.2000).

361 OJ L 373, 21.12.2004, p. 37.
} 
principle of equal opportunities and equal treatment of men and women in matters of employment and occupation (recast). ${ }^{362}$

On 16 June 2009, the Netherlands adopted the Law on Municipal nondiscrimination services (Wet gemeentelijke antidiscriminatievoorzieningen) which obliges all local governments to provide for independent and accessible local non-discrimination bureaus. Under this new Act, these Equality Bodies will have a twofold task: a) to provide for independent (legal) aid to people with a complaint about discrimination; and b) to register all complaints about discrimination. The task of conducting independent surveys concerning discrimination still lies with the Equal Treatment Commission. This newly enacted law is to be seen as a reaction of the legislature to the supposed large numbers of unreported discrimination incidents. According to a survey by the Dutch non-discrimination NGO "Art. 1", only 20 percent of all discrimination incidents in the Netherlands are reported and recorded in official numbers. ${ }^{363}$ This Act aims to lower the victims' initial hesitation to file a complaint, and to record incidents of discrimination more effectively. It can also be seen as a reaction to the critique that the main Dutch Equality Body, the Equal Treatment Commission (ETC), does not have the task to assist victims of discrimination to effectively claim their rights under the equal treatment legislation (although this task was actually in many areas already filled by local NGO's). ${ }^{364}$ From now on, officially the Dutch government has chosen a dual track in implementing not only Article 13 of the Racial Equality Directive, but also Article 20 of the Gender Employment Equality Directive (Recast) and Article 12 of Directive 2004/113/EC, all of which relate to the establishment of equality bodies: the task of providing independent assistance to victims of discrimination in pursuing their complaints about discrimination now lies with the new local Anti-Discrimination Bureaus, the task of conducting independent surveys concerning discrimination lies with the ETC. ${ }^{365}$ The tasks of publishing independent reports and making recommendations on any issue relating to such discrimination lies with both bodies. ${ }^{366}$

The imposition of positive duties on the employer to create an atmosphere favouring equal treatment is also becoming broader. On 30 June 2009, an amendment to the Dutch Arbowet (Health and Safety at Work Act) was enacted. Under the new law, employers are obliged to prevent and take action against discrimination in their organisation. 'Discrimination' now has been added to the list of possible causes of 'psychosocial pressures' on the work floor, as listed in the definition of Article 1(3)(e) of the Arbowet. Under Article 3 (2), employers are obliged to protect their employees as much as possible against psychosocial

\footnotetext{
362 OJ L 204 of 26.07 .2006 , p. 23.

$363 \mathrm{http}: / /$ www.art1.nl/artikel/8816-Nieuwe wet_en_campagne_stimuleren_melden_discriminatie (12.01.2010).

364 R. Holtmaat, Catalysts for Change? - Equality bodies according to Directive 2000/43/EC, report for the European Commission, Luxemburg: European Communities 2007, p. 25.

365 Kamerstukken II, 2007-2008, 31 439, nr. 3 (explanatory memorandum), p. 7.

$366 \mathrm{http} / / /$ www.eerstekamer.nl/9370000/1/j9vvhwtbnzpbzzc/vi2hl9afxyev/f=y.pdf $(12.01 .2010)$.
} 
pressures (as defined in Art 1). With regard to this obligation, Article 5 of the Arbowet obliges employers to make a "risk assessment" with regard to the existence of risks of psychosocial pressures (including i.e. discrimination, 'mobbing' and sexual harassment). In addition to this assessment the employer has to adopt a plan of action (Art 5(3) Arbowet) with regard to the identified risks. $^{367}$

\subsubsection{Linking ethnic origin with nationality}

Discrimination on grounds of nationality or national origin is often a mere proxy for discrimination on grounds of ethnic origin. Therefore, issues concerning discrimination on grounds of race and/or ethnic origin could often also come to surface through a stricter link with issues of migration and the status of third country nationals on the territory of the EU Member States. Examples of employment discrimination, such as described in Section 3.1, often illustrate the proximity of discrimination on grounds of ethnic origin and of discrimination on grounds of nationality or national origin.

It should therefore come as no surprise if, in a number of EU Member States, these grounds appear in anti-discrimination legislation alongside the grounds listed in Art. 19 TFEU (former Art. 13 EC), ${ }^{368}$ with the most recent illustration being the vordse kohtlemise seadus [Equal Treatment Act] which entered into force in Estonia on 1 January $2009 .{ }^{369}$ In France, the HALDE (French Equal Opportunities and Anti-Discrimination Commission) delivered two decisions relating to the refusal to pay the family benefits for children who have entered the territory outside the procedure of family reunification. ${ }^{370}$ Consistent with the positions followed by the national and international courts, the HALDE considers the refusal as discriminatory and contrary to Article 14 ECHR and to the Convention on the Rights of the Child. In Italy, the first instance Court of Brescia, employment section (Tribunale di Brescia, sezione lavoro) held on 26 January 2009 that the ordinance adopted by the mayor of Brescia (ord. 52053, issued on 21 November 2008), providing 1,000 euros grants to couples of residents who had a child in 2008 if at least one of the parents was Italian, constituted a discrimination in violation of Article 43 of the Immigration law Act (Testo Unico dell'immigrazione, d.lgs. 286/98). ${ }^{371}$

\footnotetext{
367 Netherlands/Kamerstukken II, 2008-2009, 31811 nr. A.

368 O. De Schutter (2009) Links between Migration and Discrimination, European Commission, Directorate-General for Employment, Social Affairs and Equal Opportunities, available at http://ec.europa.eu/social/BlobServlet?docId=4245\&langId=en (20.12.2009).

369 Estonia/Riigikantselei (23.12.2008) Riigi Teataja I, 56, 315; unofficial and incomplete translation available at: http://www.legaltext.ee/et/andmebaas/tekst.asp?loc=text\&dok=XXXX006\&keel=en\&pg $=1 \&$ ptyyp $=$ RT\&tyyp $=X \& q u e r y=v \% F 5$ rdse + kohtlemise + seadus $(08.10 .2009)$.

370 France/HALDE/n ${ }^{\circ} 2009-249$ and 2009-250/29.06.2009, http://www.halde.fr/spip.php?page $=$ article\&id article $=12969 \&$ liens $=$ ok $(10.10 .2009)$.

371 http://www.meltingpot.org/IMG/pdf/ordinanzatribunale.pdf (01.10.2009).
} 
The rising importance of the prohibition of discrimination on grounds of nationality was further highlighted by the ECtHR when it found Latvia to have committed discrimination against Ms Natālija Andrejeva, a "permanently resident non-citizen" of Latvia who was previously a national of the former USSR. Because she does not have Latvian citizenship, Ms Andrejeva was denied pension rights since, in her case, the fact of having worked for an entity established outside Latvia despite having been physically in Latvian territory did not constitute "employment within the territory of Latvia" within the meaning of the State Pensions Act. ${ }^{372}$

\subsubsection{Strengthening civil society}

NGOs have a crucial role to fulfil in the implementation of anti-discrimination legislation. The strengthening of their capacities is therefore crucial. The project funded in Germany by the Federal Ministry for Work and Social Matters and implemented by the Deutsches Institut für Menschenrechte [German Institute for Human Rights] aiming to encourage civil society organisations to take legal actions against discrimination e.g. by strategic litigation, ${ }^{373}$ or in Lithuania the publication by the Lithuanian Centre for Human Rights of the manual "Litigation in Discrimination Cases" 374 set benchmarks for practices within other countries. The establishment of bodies that can provide advice to social partners or other actors as to best practices in the field, in order to accelerate learning, can also be an important contribution. One example is the Centre of Excellence supported in Germany by the Federal Ministry for Labour and Social Affairs, which is a focal point for information on instruments of the Behindertengleichstellungsgesetz (BGG) [Act on Equal Opportunities for Disabled Persons]. ${ }^{375}$ Another example is the publication in the UK in October 2009 by the Equality and Human Rights Commission (EHRC) of a report entitled "Integration in the Workplace", ${ }^{376}$ describing the policies and practices that organisations have adopted to encourage lesbian, gay, bisexual and older employees and those with differing religions or beliefs to take up recruitment, promotion or advancement opportunities in the workplace.

\footnotetext{
372 Eur. Ct. HR (GC)/Andrejeva v. Latvia (Appl. No. 55707/00), judgment of 18 February 2009 (final), http://www.echr.coe.int (12.01.2010).

373 http://www.institut-fuer-menschenrechte.de/de/projekt-diskriminierungsschutzhandlungskompetenz-fuer-verbaende/ (22.10.2009).

374 http://www.manoteises.lt (12.01.2010).

$375 \mathrm{http}: / /$ www.dbsv.org/infothek/barrierefreiheit/bundeskompetenzzentrum-barrierefreiheit/. Background information available at http://www.bmas.de/portal/33798/2009_07_02 $\quad 02$ hintergrundtext_ kompetenzzentrum.htm $\underline{1}(22.10 .2009)$.

376 http://www.equalityhumanrights.com/media-centre/new-workplace-report-launched/ (19.10.2009).
} 


\subsubsection{Equal treatment between women and men}

Some progress was reported in the area of equal treatment between women and men. While a 2009 study provides detailed new evidence on the factors that contribute to the gender pay gap in Ireland (The Gender Wage Gap in Ireland $^{377}$ ), gender inequality appears to be diminishing, as shown in the first Progress Report on the National Women's Strategy 2007-2016 ${ }^{378}$ which outlines significant positive outcomes for women since the strategy was published in 2007. In Belgium, using 2006 data, the federal Instituut voor de Gelijkheid van Vrouwen en Mannen - Institut pour l'Égalité des Femmes et des Hommes [Institute for the Equality of Women and Men] reported that the wage gap with regard to the gross hourly wages of full-time and part-time employees across all sectors was 11 per cent, although viewed from the perspective of gross annual income - for which the effect of the fact that a greater share of women than men are employed on a part time basis, plays fully - it runs up to 25 per cent. Nevertheless, the Institute sees a relatively constant decrease in the wage gap. ${ }^{379}$ Problems remain, however. In Cyprus, legislation ${ }^{380}$ was amended in 2009 in order to strengthen the Gender Equality Committee's functions and powers and offer greater protection to victims of discrimination. In France, HALDE (French Equal Opportunities and Anti-Discrimination Commission) adopted a resolution relating to equality between men and women in June $2009,{ }^{381}$ insisting on the effective implementation of the Act on equal wages between men and women of 23 March 2006, ${ }^{382}$ notably within the private sector. As part of the government's action plan for promoting gender equality in employment, the French Minister of Labour, Social Affairs and Solidarity invited the social partners to negotiate on this issue in November 2009. As a result, a new law is to be drawn up aimed at improving the situation of women in the labour market in relation to the existing pay and career gap, inequalities in career promotion and access to senior management posts.

\footnotetext{
377 The Equality Authority (2009) The Gender Wage gap in Ireland, available at: http://www.equality.ie/index.asp?locID=105\&docID=817 (02.10.2009).

378 Ireland/Department of Justice, Equality and Law Reform, National Women's Strategy 20072016, available at: http://www.justice.ie/en/JELR/NWS2007-2016en.pdf/Files/NWS20072016en.pdf (02.10.2009).

379 Belgium/Institute for the Equality of Women and Men (2009) De loonkloof tussen vrouwen en mannen in België, p. 67, available at: http://igvm-iefh.belgium.be/nl/binaries/24\%20\%20Loonkloof\%202009 NL tcm336-44052.pdf (Dutch) (08.10.2009); L'écart salarial entre les femmes et les hommes en Belgique, p. 67, available at: http://igvmiefh.belgium.be/fr/binaries/24\%20-\%20EcartSalarial\%202009 FR tcm337-44055.pdf (French) (08.10.2009).

380 The Equal Treatment of Men and Women in Occupation and Vocational Training Law 205(I)/2002

381 France/HALDE/legal direction/deliberation $n^{\circ} 2009-237 / 29.06 .2009$, http://www.halde.fr/IMG/pdf/4686.pdf (12.10.2009).

382 France/Act ${ }^{\circ} 2006-340$ of 23 march 2006 relating to the equality of salaries between men and women: online in French only:

http://www.legifrance.gouv.fr/affichTexte.do?cidTexte=JORFTEXT000000816849\&fastPos=

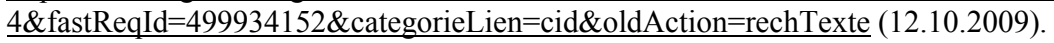


In 2009, the Slovak government adopted a strategy for gender mainstreaming for the years 2009-2013, which is being elaborated in cooperation with NGOs and the Slovak National Centre for Human Rights. In the UK, the Equality and Human Rights Commission (EHRC) carried out a formal inquiry into gender discrimination in the financial services sector, looking at some of the UK's leading financial services companies. The findings reveal that women receive about 80 per cent less in performance-related pay than their male colleagues, which is a major factor behind the substantial pay gap in the financial services sector in the UK. ${ }^{383}$ In December 2009, the European Commission adopted its annual report on equality between women and men, highlighting the persisting gender gaps in employment rates, pay, working hours, positions of responsibility, share of care and family responsibilities as well as poverty rates across the EU. ${ }^{384}$ In light of these findings, the European Commission considers that the gender dimension needs to be strengthened in all spheres of society, by transforming commitment to gender equality into action through efficient mechanisms and structures for implementation at both EU and national levels.

Perhaps the most contested provision of Directive 2004/113/EC was Article 5 (Actuarial factors), concerning the use of sex as a factor in the calculation of premiums and benefits for the purposes of insurance and related financial services. Article 5(2) allows for certain exceptions to the rule according to which, in principle, considerations based on sex should not result in differences in individuals' premiums and benefits. In Latvia, on 8 September 2009, the Cabinet of Ministers adopted regulation No 1002 "On Regulations on Application of Differential Treatment in Determining Insurance Premiums and Insurance Compensation", providing that differential treatment between men and women shall be allowed in life insurance, ${ }^{385}$ taking into account the difference in the average life expectancy between men and women, and that the introduction of same tariffs for men and women would lead to higher costs for clients. $^{386}$

\footnotetext{
383 http://www.equalityhumanrights.com/media-centre (19.10.2009).

384 European Commission (December 2009) Equality between men and women-2010, COM (2009), Brussels, available at:

http://ec.europa.eu/social/main.jsp?langId=en\&catId=89\&newsId $=660$

385 Latvia/MK noteikumi Nr.1002 "Noteikumi par atšķirìgas attieksmes izmantošanu apdrošināšanas prēmijas un apdrošināšanas atlīdzības noteikšanā" [Cabinet of Ministers regulations No 1002 On Regulations on Application of Differential Treatment in Determining Insurance Premiums and Insurance Payments] (08.09.2009), available at http://www.likumi.lv/doc.php?id=197439\& from=off (15.09.2009).

386 Latvia/Anotācija Ministru kabineta noteikumu projektam "Noteikumi par atšksirīgas attieksmes izmantošanu apdrošināšanas prēmijas un apdrošināšanas atlīdzības noteikšanā", available at http://www.mk.gov.lv/doc/2005/FManot 16072009.2675.doc (15.09.2009).
} 


\subsection{Positive actions}

Positive action measures can improve the professional integration of minority groups. In Cyprus, discussions were launched on a "Law introducing special provisions for the hiring of persons with disabilities in the wider public sector", which sets out quotas in the employment of persons with disabilities at 10 per cent of the number of the vacancies to be filled in at any given time. ${ }^{387}$ In Spain, in its Decision 13/2009 of 19 January 2009, the Spanish Constitutional Court dismissed an action filed against various articles of the Law 4/2005 of 18 February 2005 of the Basque Parliament on equality between women and men, rejecting the claim that the establishment of gender quotas on electoral lists was violating the constitutional principles of merit and ability, the freedom of the political parties to prepare the lists and the right to equal access to the public services. ${ }^{388}$ In Slovenia, the Constitutional Court similarly dismissed a claim that the Vocational Rehabilitation and Employment of Persons with Disabilities Act, Article 62 of which provides that employers who employ at least 20 workers must ensure that a certain proportion of those employed are persons with disabilities, constitutes a disproportionate interference with the right of these employers to free economic initiative enshrined in the first paragraph of Article 74 of the Constitution. ${ }^{389}$ These cases illustrate a growing recognition that 'merit' may be a falsely neutral criterion, and that the effective application of the principle of non-discrimination may require positive action in order to combat existing stereotypes.

\section{Action plans}

Another useful tool to promote effective integration and to step up the fight against discrimination is the adoption of an action plan identifying gaps and obstacles, and defining the timeframe within which they should be removed. In Spain for instance, the Council of Ministers approved a Human Rights Plan in December 2008, and subsequently adopted an Order ${ }^{390}$ creating a Commission for Monitoring the Plan in order to assess the execution of the measures taken under this Plan. ${ }^{391}$ On 10 July 2009, it also approved the Third Plan of Action for Disabled People for the period 2009-2012, defining the Government's strategy in the field of disability. ${ }^{392}$

\footnotetext{
387 The House of Representatives in Cyprus approved the bill submitted by the government, and the Recruitment of Persons with Disabilities in the Wider Public Sector (Special Provisions) Law of 2009 (Law No. 146(I)/2009) was published and put into force as from 23.12.2009.

$388 \mathrm{http}: / /$ www.boe.es/boe/dias/2009/02/13/pdfs/BOE-A-2009-2502.pdf $(01.10 .2009)$.

389 http://odlocitve.us-rs.si/usrs/usodl.nsf/o/79F11A62440695CCC125756D002A8D50 (21.09. 2009).

390 Order PRE/1597/2009 (15 June 2009).

$391 \mathrm{http} / / / w w w . b o e . e s /$ boe/dias/2009/06/16/pdfs/BOE-A-2009-9981.pdf (01.10.2009).

392 http://www.lamoncloa.es/ConsejodeMinistros/Referencias/_2009/refc20090710.htm\#Discapacidad (01.10.2009).
} 


\section{The rights of the child and protection of children}

\subsection{Legal framework}

\subsubsection{UN Convention and policy guidelines}

The implementation of the Convention on the Rights of the Child (CRC) has been strengthened in different ways during 2009. In June, the UN Committee on the Rights of the Child adopted a new general comment, dedicated to the general principle reflected in article 12 CRC that children have the right to be heard. The Committee presents a legal analysis of article 12 and explains the requirements to fully realise this right, discusses the connection of article 12 with the three other general principles of the Convention and other articles, outlines the requirements and the impact of the child's right to be heard in different situations and settings, and sets out the basic requirements for the implementation of this right. ${ }^{393}$ Also in 2009, the UN Human Rights Council decided to establish an Open-ended Working Group to explore the possibility of elaborating an optional protocol to the Convention on the Rights of the Child to provide a communications procedure complementary to the reporting procedure under the Convention. ${ }^{394}$

In February 2009, the UNICEF Innocenti Research Centre published its Handbook on the Optional Protocol to the Convention on the Rights of the Child on the Sale of Children, Child Prostitution and Child Pornography, which describes the genesis, scope and content of the Protocol, and provides examples of measures taken by States Parties to fulfil their obligations under this instrument. ${ }^{395}$

A set of Guidelines for the Alternative Care of Children were adopted by the UN General Assembly without a vote on 18 December 2009 (A/RES/64/142). The Guidelines set out desirable orientations for policy and practice with the intention of enhancing the implementation of the Convention on the Rights of the Child, and of relevant provisions of other international instruments regarding the protection and well-being of children deprived of parental care or

\footnotetext{
${ }^{393} \mathrm{http} / /$ www2.ohchr.org/english/bodies/crc/docs/AdvanceVersions/CRC-C-GC-12.doc (30.09.2009).

394 http://www2.ohchr.org/english/bodies/hrcouncil/docs/11session/L-11.doc (30.09. 2009).

${ }^{395}$ See http://www.unicef-irc.org/cgi

bin/unicef/download_insert.sql?PDFName $=\&$ ProductID=547\&DownloadAddress $=/$ publicatio $\mathrm{ns} / \mathrm{pdf} /$
} 
who are at risk of being so. ${ }^{396}$ Data released in March 2009 by the Bulgarian "For our children" foundation showing that in Bulgaria, 2083 newborn and toddlers were abandoned by their parents (mostly single parents or unemployed) and listed in orphanages in 2007 - with nearly $70 \%$ of the abandoned children never receiving visits from their parents - illustrate the importance of this issue in EU Member States. ${ }^{397}$

Finally, also in December 2009, UNHCR published its Guidelines on International Protection: 'Child Asylum Claims under Articles 1(A)2 and 1(F) of the 1951 Convention and/or 1967 Protocol relating to the Status of Refugees' which offer substantive and procedural guidance on carrying out refugee status determination in a child-sensitive manner. The importance of these guidelines cannot be overstated in view of the fact that, looking at separated, asylumseeking children alone, according to UNHCR over 15,000 unaccompanied and separated children claimed asylum in the European Union, Norway and Switzerland in 2009.

\subsubsection{Integrated European policy approaches}

The Swedish Presidency of the EU was marked by the high relevance given to the Rights of the Child in the adoption of the new multi-annual programme of the European Council - the Stockholm Programme. The Stockholm Programme, which defines EU work in the area of justice and home affairs for the period 2010-2014, covers policies in areas such as of citizenship and fundamental rights, justice, security, asylum, migration and visa policy, police and customs cooperation, rescue services, criminal and civil law cooperation.

The Stockholm Programme highlights that the rights of the child concern all EU policies and that they must be systematically and strategically taken into account with a view to ensuring an integrated approach. The European Council calls upon the Commission to identify measures, to which the Union can bring added value, in order to protect and promote the rights of the child. Children in particularly vulnerable situations, such as victims of sexual exploitation and abuse, victims of trafficking and unaccompanied minors in the context of immigration policy are specifically mentioned. The Council calls for the development of child abduction alert mechanisms, by promoting cooperation between national authorities and interoperability of systems and addresses other aspects relevant to child protection as discussed further below.

At the level of the Council of Europe, on the basis of work undertaken under the Programme "Building a Europe for and with children", the Committee of Ministers adopted on 18th November the Policy Guidelines on Integrated

${ }_{397}^{396} \underline{\mathrm{http}: / / \text { www2.ohchr.org/english/bodies/hrcouncil/docs/11 session/L-11.doc }}(30.09 .2009)$. 
National Strategies for the Protection of Children from Violence. ${ }^{398}$ Guidelines on Child-Friendly Justice are also under preparation. ${ }^{399}$ In an issue paper on Children and Juvenile Justice: Proposals for Improvements, the Commissioner for Human Rights called Member States to review their justice policy and to offer alternatives to ordinary justice and detention. ${ }^{400}$

The Council of Europe adopted a Recommendation on the nationality of children $^{401}$ with the main aim to ensure the right of children to a nationality, facilitate their access to a nationality and reduce statelessness. It also adopted a Recommendation on the education and social inclusion of children and young people with autism spectrum disorders ${ }^{402}$. In June, it launched a platform on children's rights, which includes a network of focal points and representatives of civil society, ombudspersons, international organisations and experts, and research institutions. ${ }^{403}$ The Council of Europe and the European Commission jointly organised a conference on "Challenges in adoption procedures: ensuring the best interests of the child" (Strasbourg, 30 November - 1 December 2009). Three new projects (on child participation, child-friendly social services and child-friendly health care) have been launched at the end of 2009. The Council of Europe has also carried out a feasibility study on the Rights and Legal Status of Children being brought up in Various Forms of Marital or Non-marital Partnerships and Cohabitation which highlighted the need for a new legal instrument on this subject.

$398 \mathrm{http} / /$ www.coe.int/t/transversalprojects/children/News/Guidelines/ Recommendation\%20CM\%20A4\%20protection\%20of\%20children\%20_ENG_BD.pdf

399 https://wcd.coe.int/ViewDoc.jsp?id=1410751\&Site=CM\&BackColorInternet= C3C3C3\&BackColorIntranet=EDB021\&BackColorLogged=F5D383 (30.9.2009).

400 https://wcd.coe.int/ViewDoc.jsp?id=1460021\&Site=CommDH\&BackColorInternet $=$ FEC65B\&BackColorIntranet=FEC65B\&BackColorLogged=FFC679. The Commissioner also published a book paying tribute to Janusz Korczak and encompassing lectures of eminent experts on children's rights. The publication recalled current challenges faced by children in relation to participation, respect for their best interest, detention, corporal punishment and care institutions.

401 Recommendation $\mathrm{CM} / \operatorname{Rec}(2009) 13$, adopted on 9 December 2009

402 https://wcd.coe.int//ViewDoc.jsp?Ref=CM/Rec(2009)9\&Language=lanEnglish\&Ver= original\&BackColorInternet $=\mathrm{C} 3 \mathrm{C} 3 \mathrm{C} 3 \&$ BackColorIntranet $=$ EDB021\&BackColorLogged $=\mathrm{F} 5$ D383

$403 \underline{\mathrm{http}: / / \text { www.coe.int/t/transversalprojects/children/events/LaunchMeetingPlatform_en.asp }}$ $(30.09 .2009)$. 


\subsection{Monitoring child protection and well- being}

\subsubsection{Establishing an analytical framework}

The relevance that the question of the Rights of the Child would acquire under the Swedish Presidency was anticipated by the fact that the 11th Annual EUNGO Forum on Human Rights, marking the start-up of events organised under the Swedish EU Presidency, was devoted to the topic of violence against children. The implementation of the EU Guidelines on the Rights of the Child (which mainly concern external human rights policy) and of legal frameworks relating to the prohibition of all forms of corporal punishment, as well as the question of children in conflict and crisis situations were discussed during the conference as outstanding issues that required continued attention by the EU institutions and Member States.

Similarly, the 4th Forum on the Rights of the Child, organised by the European Commission, which focused for the first time on the external dimension, dealt with the issue of the fight against child labour, addressing questions of social protection and corporate social responsibility. Finally, the Annual Dialogue on the Multilevel Protection and Promotion of Fundamental Rights, co-organised by the Committee of the Regions and the FRA, discussed the use of indicators on the rights of the child, and combating child trafficking at the local and regional levels.

Following the work carried out in 2007 and 2008 by the European Commission and the Member States in the context of the European Strategy for Social Inclusion, notably the report prepared by the EU task force on child poverty and child well-being, the European Commission launched a new study in 2009 aimed at contributing to the development of more coherent and integrated policies regarding child poverty. Preliminary conclusions of the study, which aims to assist in the development of the analytical framework for reporting within the Open method of Coordination (OMC) and a limited set of child wellbeing indicators, were presented at a conference in Brussels on 26 November 2009. These preliminary conclusions refer to the need to reflect on the various phases of childhood, the need for a comprehensive set of indicators to monitor child poverty and well-being and to develop data infrastructure and improve the data situation. At the conference, the need for involving child participation in studies concerning children was also emphasised. Also the UNICEF Innocenti Research Center Social Monitor $2009^{404}$ was devoted to Child Well-being, focusing on evolving challenges in Central and Eastern Europe (as well as the Commonwealth of Independent States) addressing crucial aspects of child protection in some EU Member States.

${ }^{404}$ http://www.unicef-irc.org/publications/pdf/ism_2009.pdf 
Third country nationals separated from both parents or primary carer who have arrived in EU Member States, and trafficked children, were identified as children in particularly vulnerable situations by the Summary Report on Developing Indicators for the Protection, Respect and Promotion of the Rights of the Child in the European Union, published by the FRA in March. The FRA work on indicators takes the Convention on the Rights of the Child as a base, providing an initial toolkit to evaluate the impact of EU law and policy on children's status and experience across various fields. The indicators, which complement and build upon previous efforts to develop child indicators at EU level, also aim to highlight the existing gaps both in current EU provision and available data, providing a springboard for future legal, policy and research development. ${ }^{405}$ In July 2009, the FRA presented the results of its research on Child Trafficking in the European Union. ${ }^{406}$

In March 2009, the FRA started research on the situation of separated, asylumseeking children in EU Member States ${ }^{407}$ aimed at analysing the living conditions and legal procedures affecting these children, by researching aspects such as their accommodation (type of accommodation, location, cleanliness and sanitary conditions, food, opportunities to practice religion and recreation), the role of social workers, health care, education and possibilities of employment, and social interaction. Regarding legal procedures, the key issues covered include legal guardianship, legal representation and advice, age assessment, family tracing and reunification, and asylum procedures. Issues of discrimination and other forms of mistreatment, as well as detention, are also addressed. Additional aspects of the protection of separated, asylum-seeking children are covered in the following chapter on asylum, immigration and integration of migrants.

A comprehensive study called Violence in the EU examined - Policies on Violence against Women, Children and Youth in 2004 EU Accession Countries was published in September 2009. The study was part of a project on "Ways of Implementing the EU Directives on Violence against Women, Children and Youth: Good Practices and Recommendations", co-financed by the European Commission under the Daphne II Programme and led by the University of Ljubljana. ${ }^{408}$ The publication provides a comparative analysis of legislation and policies within the 10 Member States that joined the European Union in 2004.

\footnotetext{
${ }^{405} \mathrm{http} / / /$ fra.europa.eu/fraWebsite/products/publications_reports/pub-rightsofchildsummary_en.htm

$406 \mathrm{http} / / /$ fra.europa.eu/fraWebsite/products/publications_reports/pub_child_trafficking09_en.htm

$407 \mathrm{http} / / /$ fra.europa.eu/fraWebsite/research/research_projects/proj_separated-asylum_en.htm

408 http://www.ff.uni-lj.si/fakulteta/Dejavnosti/ZIFF/DAPHNEeng/Publications/publications.html (03.99.2009).
} 


\subsubsection{Care and the prevention of violence against children}

\section{Member State initiatives}

In Germany, one of the focus areas of the 2005-2010 national action plan adopted under the auspices of the Bundesministerium für Familie, Senioren, Frauen und Jugend (BMFSFJ) [Federal Ministry for Family Affairs, Senior Citizens, Women and Youth] was non-violent upbringing (Aufwachsen ohne Gewalt): the action plan considers the relationship between the upbringing of children with a migration background living in poor households and violent methods of discipline, and seeks to support families and children to live together without violence. ${ }^{409}$ As clearly illustrated by a report on Romania of the NGO Save the Children, however, a legal ban on corporal punishment is not enough to ensure adequate protection of the child: according to the report, only 13 per cent of the people who declared they knew cases of children subject to ill treatment actually notified the competent authorities. ${ }^{410}$ The UN Committee on the Rights of the Child also expressed serious concerns regarding Romania's high prevalence of abuse and neglect of children, including in the home, and regarding the lack of a comprehensive nationwide strategy in this regard. ${ }^{411}$

In Slovenia, in order to address this problem, the National Assembly adopted a Resolution on the 2009-2014 National Programme on Prevention of Family Violence, ${ }^{412}$ identifying a set of objectives and measures for the prevention and reduction of family violence. Similarly in the UK, a report presented in March 2009 entitled "The Protection of Children in England: A Progress Report"413 made a number of recommendations including, among other things, further accountability for individuals and departments working in child services at a national and local level, increased support for children and improved interagency cooperation in order to protect children from violence and abuse within households. Following the presentation of the report the Government issued an action plan ensuring a follow-up to these recommendations. ${ }^{414}$

\footnotetext{
${ }^{409}$ http://www.bundespruefstelle.de/bmfsfj/generator/RedaktionBMFSFJ/Abteilung5/PdfAnlagen/nap-zwischenbericht,property $=$ pdf,bereich $=$ bmfsfj, sprache $=$ de, $r w b=$ true.pdf (22.10.2009).

410 Salvati Copiii - Romania (2008) Alternative Report to the Third and Fourth Periodic Report submitted by Romania to the UN Committee for the Rights of the Child. Full text available at: http://www.salvaticopiii.ro/romania/resurse/rapoarte.html. (30.09.2009).

411 Committee on the Rights of the Child, Fifty-First Session (2009) Consideration of Reports Submitted by States Parties under Article 44 of the Convention; Concluding Observations Romania. Full text available at: http://www2.ohchr.org/english/bodies/crc/docs/co/CRC-CROM-CO-4.pdf. (26.09.2009).

412 See: http://www.mddsz.gov.si/fileadmin/mddsz.gov.si/pageuploads/dokumenti $\mathrm{pdf} /$ resolution prevention familiy violence 09 14.pdf, (28.09. 2009).

413 http://publications.everychildmatters.gov.uk/eOrderingDownload/HC-330.pdf (14.10.2009).

$414 \mathrm{http}: / /$ publications.desf.gov.uk/eOrderingDownload/DCSF-Laming.pdf (14.10.2009).
} 
Another major comparative research project on the implications of a legal ban on corporal punishment, covering experiences and attitudes of parents in France, Sweden, Spain, Germany and Austria was initiated in spring 2009, with the first results being available at the end of 2009. The cross-national study confirmed the strong impact of anti-violence legislation, which leads to a significant reduction of the practice of corporal punishment. ${ }^{415}$ A particular focus of the study was the situation of migrant families and the impact that lack of integration can have on violence against children.

In Belgium, the Council of Europe Commissioner for Human Rights urged the authorities to comply with European standards by passing a law prohibiting explicitly corporal punishment, including in the home. The Council of Europe campaign against corporal punishment contributed to keeping this issue in the public debate of many EU Member States, including France and the UK.

\section{Care institutions}

The abuse of children within care institutions remains a major source of concern, particularly as regards children with disabilities. In Bulgaria, on 4 September 2009 the Bulgarian Helsinki Committee (BHC) filed a lawsuit under the Protection Against Discrimination Act against the Supreme Prosecutor's office for failure to investigate 75 death cases and an undetermined number of bodily injuries of children with mental and physical disabilities living in institutions. ${ }^{416}$ According to the Bulgarian authorities the allegations in the $\mathrm{BHC}$ lawsuit do not relate to acts of discrimination, but to the implementation of criminal law, and should therefore be addressed on the bases of the criminal and criminal procedure legislation of Bulgaria. The authorities were called upon by the Council of Europe Commissioner for Human Rights to adopt a comprehensive de-institutionalisation programme with the support of the local authorities and the participation of civil society and the parents concerned. The Commissioner also stressed the importance of inclusive education. ${ }^{417}$

In Denmark, NGOs have denounced the fact that children with disabilities are being institutionalised, instead of their families being supported in raising them at home. ${ }^{418}$ In response, the Ministry of Social Affairs considers that to a significant extent funds are available to allow young persons to live with their families when appropriate, but is nevertheless carrying out a mapping of the placement of such children to see if rules in this area need to be amended. In Poland, families of disabled children protested against the decision of the government to set a minimum income threshold as a condition for the reception of the carer's allowance (zasitek pielegnacyjny), which is already set at a very low level (and below the minimum wage), although it is intended to compensate

\footnotetext{
415 Project lead: Kai Bussmann, University of Halle/Germany; further information available at http://www.oif.ac.at and http://www.bmwfj.gv.at (19.01.2010).

416 http://www.bghelsinki.org/index.php?module=news\&lg=en\&id=2652 (01.12.2009).

417 https://wcd.coe.int/ViewDoc.jsp?id=1581941\&Site=CommDH\&BackColorInternet= FEC65B\&BackColorIntranet $=$ FEC65B\&BackColorLogged $=$ FFC679

$418 \mathrm{http}: / /$ www.alle-boerns-rettigheder.dk/Supplerende_FNRapport20091.pdf (1.12.2009).
} 
parents who gave up their jobs in order to take care of their disabled children. The Ministry of Labour and Social Policy acknowledged on 22 October 2009 that the income condition will be abolished in the new budgetary year.

In Ireland, the National Board for Safeguarding Children in the Catholic Church published new standards to address the issue of child protection in the Catholic Church in February. The standards were issued in the aftermath of controversy surrounding the inadequacy of child safety measures within the Church. The document is the third attempt by the Catholic Church to bring its internal procedures into line with statutory requirements in both the Republic and Northern Ireland. There has been some criticism of the authority of the Board to enforce compliance with the guidelines or to penalise those in the Church who fail to cooperate.

\section{Public support}

States have a positive duty to protect children from violence or abuse within the family. However, a greater emphasis should be placed on preventive measures and support for parents. Separation measures should remain limited to protecting the best interests of the child and should ensure the protection of the right to respect for private and family life as guaranteed under Article 8 ECHR, ${ }^{419}$ and Article 7 of the EU Charter of Fundamental Rights. During 2009 the European Court of Human Rights delivered over 15 judgements concerning the observance of the rights of the child in EU member States. ${ }^{420}$ The majority of cases concerned the child's right to respect for private and family life.

In addition, on 20 October 2010 the European Committee on Social Rights concluded that States Parties are required, under Article 31.2 of the Revised European Social Charter, to provide adequate shelter to children unlawfully present in their territory for as long as they are in their jurisdiction. According to the Committee "any other solution would run counter to the respect for their human dignity and would not take due account of the particularly vulnerable situation of children". ${ }^{421}$

419 The English courts have sought to define the conditions at which an intervention within the family could be justified, see Re A (children) (care proceedings: threshold criteria)[2009] EWCA Civ 853

420 Anakomba Yula v. Belgium, 10 March 2009; Weller v. Hungary, 31 March 2009; Amanalachioai v. Romania, 26 May 2009; Brauer v. Germany, 28 May 2009; Viorel Burzo v. Romania, 30 June 2009; Stagno v. Belgium, 7 July 2009; Zavoloka v. Latvia, 7 July 2009; Nenov v. Bulgaria, 16 July 2009; E.S. and others v. Slovakia, 15 September 2009; Stochlak v. Poland, 22 September 2009; Costreie v.Romania, 13 October 2009; Tsourlakis v.Greece, 15 October 2009, Vautier v.France, 26 November 2009, Eberhard et M. v.Slovenia, 1 December 2009, Zaunegger v. Germany, 3 December 2009; Tapia Gasca and D. v. Spain, 22 December 2009;

421 European Committee of Social Rights, Decision on the Merits 20 October 2009, Case Defence for Children International (DCI) v. The Netherlands, , para. 64. 
In April 2009 the Vienna University Institute of Sociology published an empirical study on children growing up in poverty in Austria. ${ }^{422}$ The report highlights households with more than two children, single parent families and migrant background, linked to cramped, inadequate housing conditions as main factors leading to poor living conditions of children, with significant negative impact also on their school education.

In Ireland, the Ombudsman for Children has criticised State support provided to children, indicating that deficiencies in policy and practice mean that children are not receiving satisfactory support from the State. She also voiced her concern over the absence of a system for dealing with inappropriate behaviour towards children at school, the lack of an appropriate forum for dealing with allegations of abuse against staff members and the lack of statutory obligation on the State to provide aftercare support to young people no longer benefiting from child care. ${ }^{423}$ In Spain, the Defensor del Pueblo [Ombudsman] also denounced the lack of public support for families having to deal with children with behavioural problems. ${ }^{424}$ In Hungary, the Parliamentary Commissioner for Civil Rights published in September 2009 a report criticising the family support system as being too complicated, resulting in a situation in which the claimants find it difficult to choose from different forms of financial support and to gain easy access to such support. ${ }^{425}$ In Lithuania, the Ombudsperson on Children Rights devoted a report to the situation of children in large and poor families, highlighting the need for support. ${ }^{426}$

\subsection{Developments at EU and national level}

\subsubsection{Commission proposals}

In March 2009, the European Commission made two important legislative proposals related to the rights of the child. First, a Proposal for a Council Framework Decision on combating the sexual abuse, sexual exploitation of children and child pornography - repealing Framework Decision 2004/68/JHA ${ }^{427}$ - which has sought to further approximate substantive criminal law and rules on procedure in Member States in this area. The Commission

\footnotetext{
${ }^{422}$ U. Till-Tentschert, I. Vana (eds.) (2009) In Armut aufwachsen. Empirische Befunde zu Armutslagen von Kindern und Jugendlichen in Österreich, Vienna: Institute of Sociology, http://www.soz.univie.ac.at/forschung/sozialstruktur-sozialeungleichheit/http://www.soz.univie.ac.at/forschung/sozialstruktur-soziale-ungleichheit/ (12.01.2010).

423 Ireland/Ombudsman for Children (2009) Press Release: Legal gaps means children remain vulnerable, available at: http://www.oco.ie/whatsNew/press releases.aspx? article=7f7c2efl839c-4d9b-b92c-e896e9af4bc0 (17.09.2009).

$424 \underline{\mathrm{http} / / / \mathrm{www} . d e f e n s o r d e l p u e b l o . e s / \text { index.asp?destino=informes } 2 . \mathrm{asp}}(01.10 .2009)$.

$425 \mathrm{http}: / /$ www.obh.hu/ (21.10.2009).

$426 \mathrm{http}: / /$ www3.lrs.lt/pls/inter/vaikai?kalbId=2\&sakId=6588 (12.01.2010).

427 COM(2009)135 final (25.03.2009).
} 
proposal (to be replaced by a proposal for a Directive on this topic, following the entry into force of the Treaty of Lisbon) recognises that the 2004 Framework Decision has a number of shortcomings, since: it approximates legislation only on a limited number of offences; it does not address new forms of abuse and exploitation using information technology and does not remove obstacles to prosecuting offences outside national territory; it does not meet all the specific needs of child victims; and it does not contain adequate measures to prevent offences. ${ }^{428}$ The proposal also includes an obligation to require internet service providers to block access to child pornography sites. Secondly, a Proposal for a Council Framework Decision on preventing and combating trafficking in human beings, and protecting victims, repealing Framework Decision $2002 / 629 / \mathrm{JHA}^{429}$ (also to be replaced by a proposal for a Directive on this topic, following the entry into force of the Treaty of Lisbon) has sought to approximate Member States' substantive criminal law and rules on procedure in a more extensive way than the 2002 Framework Decision. The Commission proposal has aimed to improve the implementation in the EU of the 2005 Council of Europe Convention on Action against Trafficking in Human Beings, as well as the 2000 UN Protocol to Prevent, Suppress and Punish Trafficking in Persons, especially Women and Children, supplementing the UN Convention against Transnational Organised Crime. The aim is to improve judicial cooperation and protection, as well as assistance given to victims.

In the Stockholm Programme, the European Council invites the Council and the European Parliament to adopt new legislation on combating sexual abuse, sexual exploitation of children and child pornography, and the Commission to accompany this legislation, once adopted, by measures supported under the Safer Internet Programme 2009-2013. The European Council also invites the Commission to examine how Member States' competent authorities could exchange information on best practices, and to explore how the EU could promote partnerships with the private sector on this subject, and extend such public-private partnerships to the financial sector in order to disrupt the money transfers related to websites with child abuse content. Finally, the Council invites the Commission to build on the child alert mechanism and explore the creation of an EU-wide child abduction Network in order to promote cooperation between the competent authorities of the Member States, with a view to ensuring interoperability.

The Stockholm Programme requests the Commission, in order to prevent child abuse, to explore ways to enhance cooperation between Member States' competent authorities in response to the movement of child sex offenders known to be an ongoing threat. The European Council also requests the Commission to propose measures to make border checks more efficient in order to prevent human trafficking, in particular the trafficking of children. At the

\footnotetext{
${ }^{428}$ Proposal for a Council Framework on combating the sexual abuse, sexual exploitation of children and child pornography, repealing Framework Decision 2004/68/JHA, Brussels, 25.3.2009, p.3

${ }^{429} \operatorname{COM}(2009) 136$ final (25.03.2009).
} 
same time, the Council notes that the strengthening of border controls should not prevent access to protection systems by those persons entitled to benefit from them, referring to unaccompanied minors in particular. According to the Council, priority should be given to the needs of international protection and reception of unaccompanied minors. Recognising that unaccompanied minors from third countries represent a particularly vulnerable group, the European Council identifies a number of key areas requiring particular attention: the exchange of information and best practice; the smuggling of minors; cooperation with countries of origin; age assessment, identification and family tracing; and the need to pay particular attention to unaccompanied minors in the context of the fight against human trafficking.

\subsubsection{Protection at Member State level}

Although, among the EU Member States, only Denmark and Greece have ratified the 2007 Council of Europe Convention against sexual abuse and sexual exploitation of children - an instrument signed by all but the Czech Republic, Hungary, Latvia and Malta ${ }^{\mathbf{4 3 0}}$ - significant progress was made in a number of EU Member States in the protection of children's rights, sometimes in anticipation of the ratification of this convention. In Portugal, Law No. $113 / 2009$, published on 17.9.2009, ${ }^{431}$ contains a set of measures aiming at the protection of children, including in particular on the criminal registry related to conviction in case of crimes against children. In Austria, the parliament adopted the Gewaltschutzgesetz [Protection from Violence Act], effective as of 1 June 2009. The new legislation addresses specifically prevention and protection from sexual abuse and exploitation of children, e.g. by introducing in the Criminal Code employment bans for perpetrators working as professionals with children, and by explicitly criminalising wissentlichen Zugriff [deliberate access] to child abuse images on the internet (in addition to production, dissemination, etc. of such material already punishable under criminal law). ${ }^{432}$

In July 2009, the Austrian parliament passed legislation in the area of 'blended families" ${ }^{433}$ ('Patchwork-Familie'), marriage and adoption law, and provisions on maintenance of children. This Family Law Amendment Act 2009 clarifies legal responsibilities of step-parents and non-marital partners vis-à-vis their children. The new provisions (in effect as of 1 January 2010) now contain obligations of the step-parent to assist the partner in his/her custodial duties and at the same time grant the right to representation in everyday matters to that

\footnotetext{
${ }^{430}$ The Maltese Criminal Code (Chapter 9 Laws of Malta) has nonetheless introduced new provisions against sexual abuse and sexual exploitation of children by virtue of Act XXX.2007, which concern 'Participation in sexual activities with persons under age' and 'Issues of sexual exploitation in the context of trafficking.

431 http://dre.pt/pdf1sdip/2009/09/18100/0662006621.pdf (09.10.2009).

432 Legislation available at: http://www.ris.bka.gv.at/Dokumente/BgblAuth/BGBLA_2009_I_40/BGBLA_2009_I_40.html (06.10.2009)

433 Non-traditional families due to re-marriage or cohabitation (step-families).
} 
step-parent. In case of non-marital relationships, with partners living together with children in the same household, the partner of the child's parent will now have a legal responsibility to do "the utmost to protect the best interests of the child". In relation to inter-country adoptions the new legislation will allow for an optional procedure on recognition of adoption decisions made by foreign authorities; this is intended to close possible uncertainties about such decisions in regard to States not Party to the 1993 Hague Convention on Inter-country Adoption. ${ }^{434}$

In Finland, the Laki lapseen kohdistuneen seksuaalirikoksen selvittämisen järjestämisestä/lag om ordnande av utredningar av sexualbrott mot barn (1009/2008) [Act for the organisation of investigations relating to sexual offences against children] entered into force on 01.01.2009. The Act prescribes how the investigations on the suspected sex offence are to be carried out within the public health service at the request of the police, prosecution or a court. In addition, an expert working group on investigation of child sexual abuse published its report in August 2009, ${ }^{435}$ proposing streamlined procedures for the police, prosecuting, child protection, and healthcare authorities to investigate a suspicion of child sexual abuse. Progress was also registered in Hungary with the promulgation on 08.07.2009 of an Act amending the Act on the Protection of Children, in particular in order to improve the notification (early warning) system. ${ }^{436}$

\subsubsection{Child and youth special authorities}

In a number of EU Member States, special commissioners or ombudspersons for children rights play an important role in protecting and promoting these rights. In France a draft law on the institution of the Défenseur des droits was brought before the Senate in September by which the Défenseur des droits de l'enfant would lose its independent statute and its functions would be incorporated into the broader Défenseur des droits institution. ${ }^{437}$ Conversely, in Poland the Senate strengthened the Rzecznik Praw Dziecka [Law on the

434 Legislation available at:

http://www.ris.bka.gv.at/Dokumente/BgblAuth/BGBLA_2009_I_75/BGBLA_2009_I_75.pdf (06.10.2009).

435 Lasten seksuaalisen hyväksikäytön selvittäminen. Työryhmän muistio/Utredning om sexuellt utnyttjande av barn. Arbetsgruppens promemoria, Sosiaali- ja terveysministeriön selvityksiä, Social- och hälsovårdsministeriets rapporter 2009:30. Available in Finnish (with and English summary) at: http://www.stm.fi/c/document library/get file?folderId=39503\&name=DLFE-9918.pdf (30.11.2009).

436 Hungary/2009. évi LXXIX. törvény (08.07.2009).

${ }^{437}$ See Report of the 2009 European Network of Ombudspersons for Children (ENOC) Annual Conference, keynote speeches, Foreword from Dominique Versini available at http://crin.org/docs/FileManager/enoc/enocreportconferenceagparis.pdf and her editorial of 12 February 2010 on http://www.defenseurdesenfants.fr/ 
Commissioner for Children's Rights] in July $2009 .{ }^{438}$ In Bulgaria, the Council of Europe Commissioner for Human Rights called for the establishment of an independent control mechanism that could be either within an existing body or in a newly created one. ${ }^{439}$

In Austria, the Child and Youth Ombudsman of the province of Styria presented in February 2009 an innovative tool for child rights impact assessment (Kindergerechtigkeits-Check) for use by public authorities. It is based on the model developed by the Scottish Commissioner for Children and Young People, adapted to the Austrian context. ${ }^{440}$ In Slovakia, on the basis of the national action plan for children adopted by the government in January 2009, a committee for children rights was established, and legislation on the establishment of a specialised Children's Ombudsman was set in motion.

\subsubsection{Good Practices}

In Ireland, from January - October 2009, the Ombudsperson for Children Office carried out a project to better understand the lives and level of care afforded to separated children, so as to identify key issues and develop recommendations for relevant authorities. The project team visited all the hostels, and all children received an invitation to participate at "Open Day" activities organised by the Ombudsperson Office. Special software was developed through which children could type a message, record their voices or make a video. The outcomes of the project - story books, creative art, and a project report - will be followed up by the Ombudsperson Office. ${ }^{441}$

In Spain the activities of the "e-Foro de Menores" started in March 2009. The "e-Foro de Menores" is a consultative and advisory body created by the 'Defensor del Menor' of Andalucía in which children acquire an important role. The children, who are school pupils or representatives of youth organisations, assist in providing information about the needs, interests and experiences of the child population of Andalucía. Throughout 2009 several meetings and debates on-line were held, and the initial thematic focus has been on the use by children of the new information technologies.

After its successful opening in 2008, the Federal Agency for the Reception of Asylum-Seekers of Belgium, Fedasil, has maintained a day care centre/day

\footnotetext{
438 The text of the Senate's resolution on adoption of the draft law amending the law on the Commissioner for Children's Rights [Uchwała Senatu Rzeczpospolitej Polskiej z dnia 2 lipca 2009 r. w sprawie wniesienia do Sejmu projektu ustawy o zmianie ustawy o Rzeczniku Praw Dziecka i innych ustaw] is available at: http://www.senat.gov.pl/k7/dok/uch/036/492uch.pdf (12.01.2010).

439 https://wcd.coe.int/ViewDoc.jsp?id=1581941\&Site=CommDH\&BackColorInternet $=$ FEC65B\&BackColorIntranet=FEC65B\&BackColorLogged=FFC679

$440 \mathrm{http}: / /$ www.kinderanwalt.at/images/stories/kindergerechtigkeits-check-endversion-.pdf (06.10.2009)

$441 \mathrm{http} / / /$ www.crin.org/docs/FileManager/enoc/enocreportconferenceagparis.pdf
} 
nursery within the federal reception centre Rixensart. This provides shelter for a maximum of 20 separated children and allows mothers under 18 to entrust their children to the care of the centre while attending school. It may also be used by single parents whom, for administrative or medical reasons, need to leave their children there from time to time.

In Sweden, the so called "transit workshop" has been introduced in a transit housing centre for separated, asylum-seeking children, in cooperation with the Red Cross and Save the Children. Volunteers who speak the children's language(s) such as Arabic, Somali, Persian, and different Kurdish languages provide the children with educational material and information on issues such as the school system, the health care system, relevant legal procedures, and the municipalities the children are assigned to.

In Lithuania a special preventive measure "Supervision of sentenced persons" has been set up during which correctional inspection officers, police officers and representatives of child rights protection services monitor the sentenced persons' parental obligations vis-à-vis their children. ${ }^{42}$

Aspects of the protection of separated, asylum-seeking children are also addressed in the following chapter on asylum, immigration and integration of migrants.

${ }^{442}$ http://www.crin.org/docs/FileManager/enoc/enocreportconferenceagparis.pdf 


\section{Immigration and border control}

\subsection{Asylum, immigration and integration of migrants}

\section{Detention}

The conditions of detention in centres for irregular migrants and asylum seekers are still a major source of concern in 2009. For instance, in June 2009 in Denmark the Institut for Menneskerettigheder [Danish Institute for Human Rights (DIHR)] published a report concerning the living conditions of rejected asylum seekers, containing a number of recommendations for improvement. ${ }^{443}$ The Finnish chapter of Amnesty International released a statement concerning the treatment of immigrants detained under the Aliens Act, calling for detention to be a measure of last resort. ${ }^{444}$ Médecins Sans Frontières published a briefing paper in March 2009 on the conditions in detention centres for undocumented migrants and asylum seekers in Malta, ${ }^{445}$ formulating critiques that echoed those formulated earlier by the UN Working Group on arbitrary detention following its visit to Malta. ${ }^{446}$ With regards to Greece, the ECtHR found in two cases (at least one concerning an asylum applicant) that the conditions of detention amounted to degrading treatment in violation of Article 3 of the Convention (prohibition of torture and inhuman or degrading treatment or punishment). ${ }^{47}$ The number of children detained in such centres is rising in certain countries, as documented in the Netherlands in a report published in June 2009 by ECPAT ${ }^{448}$, Defence for Children International and UNICEF. ${ }^{449}$ Concerns over the detention of children were also highlighted in other countries. ${ }^{450}$ The Council of Europe Committee for the Prevention of Torture

443 http://menneskeret.dk/files/pdf/Publikationer/IMR_Udredn_6_2009.pdftext (12.01.2010).

444 Amnesty Internationalin Suomen osaston kannanotto, Ulkomaalaisten säilöönoton kynnystä nostettava ja käytäntöjä valvottava, http://www.amnesty.fi/mita-teemme/teemat/pakolaiset-jasiirtolaiset/kannanotto-ulkomaalaisten-sailoonotosta (05.12.2009).

445 Medecins Sans Frontiers (2009) "Not Criminals” Medecins Sans Frontieres Exposes Conditions for Undocumented Migrants and Asylum Seekers in Maltese Detention Centres, http://www.msf.org/source/countries/europe/malta/2009/2009_04_report_Malta.pdf (12.01.2010).

446 Annex to the United Nations Press Release, UN Working Group on Arbitrary Detention concludes Visit to Malta, 26 January 2009; http://www2.ohchr.org/english/issues/detention/docs/WGADAnnexFinal.doc (12.01.2010).

447 S.D. v. Greece (application no. 53541/07) and Tabesh v Greece (application no. 8256/07).

448 End Child Prostitution, Child Pornography and Trafficking of Children for Sexual Purposes

$449 \mathrm{http} / /$ www.defenceforchildren.nl/images/20/919.pdf (01.09.2009).

450 See for instance, as regards France the report by Human Rights Watch, Lost in Transit Insufficient Protection for Unaccompanied Migrant Children at Roissy Charles de Gaulle Airport, Sept. 2009 at

http://www.hrw.org/sites/default/files/reports/france1009webwcover_0.pdf or, concerning the UK, http://www.guardian.co.uk/uk/2009/oct/13/children-immigration-detention-health . 
(CPT) also highlighted poor detention conditions in centres for irregular migrants in a number of country reports published in 2009 and in 2010 (but covering visits done in 2009) ${ }^{451}$.

An important direction was given by the European Court of Justice in its first judgment related to the Return Directive ${ }^{452}$ in which the ECJ clearly confirmed the protective provisions on detention contained in the Return Directive (absolute character of the 6/18 months maximum period; no possibility to abuse detention as a form of "soft imprisonment" for public order reasons; obligation to release the detainee immediately if there are no more reasonable prospects of removal), in a case referred to it by a Bulgarian court.

\section{Separated, asylum-seeking children}

Although in many EU Member States the number of applications for asylum is either stable or has been decreasing, the question of separated children seeking asylum remains a serious source of concern in many countries. ${ }^{453}$ The research of the FRA on the situation of separated, asylum-seeking children in EU Member States mentioned in the previous chapter aims to complement the study on "Reception, Return and Integration Policies for, and numbers of Unaccompanied Minors in EU Member States" undertaken by the European Migration Network (EMN). ${ }^{454}$ The EMN study covers both legal and policy dimensions, such as motivations for entering EU, entry procedures, reception arrangements including integration, detention, return practices, statistics and identified best practices.

451 See CPT report to the Italian Government on the visit carried out in 2008 (CPT/Inf (2010) 12, published 20 April 2010): par. 21-50 http://www.cpt.coe.int/documents/ita/2010-12-infeng.htm; CPT report to the Austrian Government on the visit carried out in 2009 (CPT/Inf (2010) 5, published 11 March 2010): par. 34-64 http://www.cpt.coe.int/documents/aut/201005-inf-eng.htm; CPT report to the Government of the Slovak Republic on the visit carried out in 2009 (CPT/Inf (2010) 1, published 11 February 2010): par. 34-45

http://www.cpt.coe.int/documents/svk/2010-01-inf-eng.htm; CPT report to the Government of Sweden on the visit carried out in 2009 (CPT/Inf (2009) 34, published 11 December 2009): par 77-91 http://www.cpt.coe.int/documents/swe/2009-34-inf-eng.htm; CPT report to the French Government on the carried out in 2008 in the department of Guyane (CPT/Inf (2009) 32, published 10 December 2009): par. 54-77 http://www.cpt.coe.int/documents/fra/2009-32inf-fra.htm; CPT report to the Government of the United Kingdom on the visit carried out in 2008 (CPT/Inf (2009) 30, published 8 December 2009): par. 112-125 http://www.cpt.coe.int/documents/gbr/2009-30-inf-eng.htm; CPT report to the Government of Greece on the visit carried out in 2008 (CPT/Inf (2009) 20, published 30 June 2009): par. 854

http://www.cpt.coe.int/documents/grc/2009-20-inf-eng.htm; CPT report to the Finnish Government on the visit carried out in 2008 (CPT/Inf (2009) 5, published 20 January 2009): par. 37-57 http://www.cpt.coe.int/documents/fin/2009-05-inf-eng.htm.

452 Judgment of 30.11.2009 in Case C-357/09 PPU, Kadzoev

453 Unaccompanied children are not only asylum seekers; they can also be irregular immigrants or victims of trafficking. However, information in this section concerns only asylum seekers.

454 Reports available at: http://emn.sarenet.es/Downloads/prepareShowFiles.do;jessionid=67268F42682F77908B0B5 83099284C2F?directoryID=115 (5.02.2010) 
The UNHCR Observations on Greece as a country of asylum, issued in December 2009, raise serious concerns which are not uncommon in other European countries. ${ }^{455}$ The Council of Europe Commissioner for Human Rights indicated the existence of serious deficiencies regarding the guardianship of unaccompanied asylum seeking minors in Greece, ${ }^{456}$ and in his report on Italy drew attention to the significant number of unaccompanied migrant children and the necessity for the authorities to provide special attention and protection. ${ }^{457}$ An NGO report has highlighted the importance of this issue in Slovenia. $^{458}$ In Denmark, the Red Cross announced that of the 227 unaccompanied children it assisted in June 2009, 130 had disappeared: in that country, approximately half of the children disappear before their case is finalised. In Austria, a far-reaching package of amendments of asylum, residence and migration legislation presented in June 2009 has continued to meet strong opposition from refugee organisations and human and child rights groups. The new law, which was published in December 2009, includes introduction of controversial x-ray examinations for age assessments of asylumseeking children, restrictions for family reunification and possibilities for extended use of detention pending deportation of rejected asylum seekers. ${ }^{459}$

\section{Integration measures}

Another increasingly important issue is that of legal immigration. The European Pact on Asylum and Immigration envisaged to further "organise legal immigration to take account of the priorities, needs and reception capacities determined by each Member State, and to encourage integration". In the UK, The Borders, Citizenship and Immigration Act $2009,{ }^{460}$ which received royal assent on 21 July 2009, allows migrants to become British citizens by earning the right to stay by speaking English, obeying the law and paying taxes. Those who actively contribute to the community can apply earlier for citizenship, and full access to benefits and social housing will be reserved for permanent residents and citizens. In order to build on the provisions of the Borders, Citizenship and Immigration Act 2009, the UK Government proposes to introduce a points-based system to earn citizenship. This will allow more control over the number of people allowed to stay in the UK permanently and will enable the bar for settlement to be lowered or raised according to the needs of the country. The new proposals have been criticised as they will prolong the

\footnotetext{
$455 \mathrm{http} / / / \mathrm{www} . u n h c r . o r g /$ refworld/docid/4b4b3fc82.html (26.01.2010).

$456 \mathrm{https} / /$ wcd.coe.int/ViewDoc.jsp?id=1401927\&Site=CommDH\&BackColorInternet $=$ FEC65B\&BackColorIntranet=FEC65B\&BackColorLogged=FFC679

457 https://wcd.coe.int/ViewDoc.jsp?id=1428427\&Site=CommDH\&BackColorInternet $=$ FEC65B\&BackColorIntranet=FEC65B\&BackColorLogged=FFC679

458 http://www.filantropija.org/filantropija.asp?FolderId=132 (21.09.2009).

459 For the draft legislation, see: http://www.parlament.gv.at/PG/DE/XXIV/ME/ME_00065/pmh.shtml; for the statement of the NGO-Working Group on Child Refugees/Asylkoordination in July 2009, supported by 15 organisations and institutions, see: http://www.asyl.at/fakten_1/asyl_2009_07.htm (06.10.2009)

460 United Kingdom/Borders, Citizenship and Immigration Act 2009 c. 11.
} 
period required for refugees to naturalise ${ }^{461}$ and will disadvantage those who are female, non-white or disabled because of the points-based system being too demanding. ${ }^{462}$

In Greece a draft bill went through a public consultation process in 2009 providing the possibility of acquiring Greek nationality by birth in Greece, and a declaration of naturalisation (a new category in the Greek Nationality Code) for aliens' children who are born in Greece and whose parents have been residing permanently and legally in the country for five consecutive years, as well as for aliens' children who have attained at least six classes of Greek schooling in Greece.

\subsubsection{Legal developments}

\section{Employment of illegally staying third-country nationals}

A number of developments took place in 2009 in this area at EU level. Directive 2009/52/EC of the European Parliament and of the Council of 18 June 2009 providing for minimum standards on sanctions and measures against employers of illegally staying third-country nationals ${ }^{463}$ must be implemented by July $2011 .{ }^{464}$ In principle, the Directive prohibits the employment of migrants who have not been or are no longer authorised to stay on the territory ("illegally staying third-country nationals": Article 3). Employers have obligations to check and hold copies of residence permits, and to notify authorities of the employment (Article 4). There must be financial sanctions for employers who breach the prohibition of employing illegally staying third-country nationals (Article 5), who must also make back-payments to those employees (Article 6). There must also be the possibility of criminal penalties in certain cases (Articles 9-10), and there are general rules on inspections of workplaces (Article 14), and on facilitation of complaints by employees (Article 13).

The transposition of Directive 2009/52/EC on sanctions and measures against employers of illegally staying third-country nationals will take place in an increasingly complex environment. The issue of combating employment of illegally residing aliens concerns not just the 'old' EU 15 Member States, but also the 'new' EU 12 Member States, as illustrated by a study on "The situation of migrants from Belarus, Moldova and Ukraine on the Labour Markets of Latvia, Lithuania, Hungary, Poland and the Slovak Republic", which highlights

\footnotetext{
461 http://www.refugeecouncil.org.uk/policy/briefings/2009/bci_act.htm (16.10.2009).

$462 \mathrm{http} / / / \mathrm{www}$. guardian.co.uk/commentisfree/libertycentral/2009/jun/02/citizenship-british-bill $(16.10 .2009)$.

463 OJ L 168, 30.06.2009, http://eurlex.europa.eu/LexUriServ/LexUriServ.do?uri=OJ:L:2009:168:0024:0032:EN:PDF (12.01.2010).

464 Denmark, Ireland, and the UK are not taking part in the implementation of the Directive.
} 
the various reasons why migrant workers (whether illegal residents or not) may find it difficult to challenge even exploitative employment conditions. ${ }^{465}$

In the Slovak Republic, the Minister of the Interior proposed in September 2009 an amendment of the Act on the stay of aliens, ${ }^{466}$ inter alia with a view to obliging employers to inform police authorities about every termination of employment relationships with third-country nationals. ${ }^{467}$ In Ireland, controversial changes to work permit regulations took effect on 1.6.2009, although after harsh critiques from NGOs some of the changes were modified. The changes concern those who are applying for a work permit for the first time on or after 1 June 2009 and include a minimum yearly salary and stipulations of the need for documentary evidence that a labour market needs test has been carried out. They also make impossible new applications by certain categories of workers.. The UK announced in September 2009 new government action to help stop migrants being forced to work for poor wages in dangerous conditions. Schemes include Her Majesty's Revenue and Customs setting up a new team to respond to hotspots where employers are offering wages below the national minimum wage to migrant workers, awareness raising by the Health and Safety Executive of health and safety standards and the recruitment of five new enforcement officers to the Gangmasters Licensing Authority. ${ }^{468}$

\section{Protection from exploitation}

The denunciation of employers of illegally staying third-country nationals is made difficult because such illegally employed people risk being expelled from the national territory if they contact the authorities. ${ }^{469}$ They face the same difficulty if they seek to complain before courts about their employment conditions, even where they are formally allowed to do so. ${ }^{470}$ Article 13(4) of the Employers Sanctions Directive (2009/52/EC) on sanctions and measures against employers of illegally staying third-country nationals does not appear to constitute a satisfactory safeguard against this risk: this provision only stipulates that stay permits of a limited duration can be delivered on a case-by-case basis where the complaints concern particularly exploitative working conditions or the employment of minors. Member States should therefore make full use of the possibilities offered by the Directive. The Directive obliges Member States to

\footnotetext{
465 The situation of migrants from Belarus, Moldova and Ukraine on the Labour Markets of Latvia, Lithuania, Hungary, Poland and the Slovak Republic, p.67, available at http://soderkoping.org.ua/files/pages/20468/2.pdf (15.10.2009).

466 Slovakia/zákon 48/2002 (13.12.2001).

${ }^{467}$ http://www.minv.sk/?tlacove-spravy\&sprava=od-buduceho-roka-sa-zmenia-niektorepravidla-pre-cudzincov (19.10.2009).

$468 \mathrm{http} / / /$ www.communities.gov.uk/news/communities/1346644 (22.10.2009).

469 This difficulty is highlighted in Romania by: Romania/ARCA - Romanian Forum for Refugees and Asylum Seekers, the Group of Initiative for Dialogue, Pro WOMEN Foundation (2009) Talk to Us! Study on the Working Conditions of Foreign Workers in Romania,Bucharest: ARCA RFRA and Soros Foundation, available at: http://www.adosahrom.ro/proiecte.php. (23.07.2009).

470 A specific problem exists in countries in which the labour courts only can entertain disputes related to an existing employment contract.
} 
define the conditions under which they may grant temporary residence permits in a similar way as to that already done for victims of trafficking under Directive 2004/81. ${ }^{471}$

This is why, in Belgium, NGOs have proposed that inspections with the aim of combating abuses concerning labour legislation would no longer lead to the Dienst Vreemdelingenzaken - Office des Etrangers [Office of Foreigners Affairs] of the Ministry of the Interior being notified of the presence of illegally staying workers. Indeed, in Finland, the occupational safety and health authorities are not required to inform the police of abusive employment practices, including abuse of which third-country nationals working without a permit are victims ${ }^{472}$, even though OHS authorities can submit the matter to the police for further investigation. ${ }^{473}$ This contrasts with the situation in Latvia, where there exists a close cooperation between Valsts Robežsardze [the State Border Guard (SBG), in charge of combating illegal immigration and of expulsion procedures] and Valsts Darba inspekcija (VDI) [The State Labour Inspectorate (SLI), which monitors compliance with employment legislation] in detecting illegal employment: only the Tiesībsarga birojs [Ombudsman's Office] is under an obligation not to disclose data received from complainants, and only those filing complaints with the Ombudsman are protected from victimisation.

In Germany, there are examples of trade unions playing an active role in supporting irregular migrants by contacting the employer and seeking to solve the dispute by amicable means, without having to rely on courts and thus without creating a risk that the worker will be expelled as a result of filing a complaint. In other countries, such as in Spain under Article 31 of the Organic Law on derechos y libertades de los extranjeros en España y su integración social [rights and liberties of aliens in Spain and their social integration], ${ }^{474}$ it may be possible on the basis of existing legislation to grant exceptional residence permissions to aliens for collaborating with justice, as is done for victims of human trafficking. To the extent that a significant proportion of illegally employed migrant workers are hired through employment agencies, measures could also be adopted to tackle these agencies' practices. In the Netherlands, the Lower Chamber of Parliament has agreed to an amendment to the Dutch Civil Code (new Art. 7:692 BW) under which companies making use of the services of employment agencies become severally liable to pay the minimum wage and minimum holiday bonus to the employee, regardless of the applicable agreements between the employment agency and the employee or the

\footnotetext{
${ }^{471}$ The indicated criminal offences constituting the bases for granting residence are related specifically to situations where employees are mostly exposed to exploitation (Art. 9(1)(c) particularly exploitative working conditions; Art. 9 (1)(e) - employment of a minor), while remaining infringements listed under Art. 9 are penalised for other reasons.

472 Written answers to questions received from Maarit Lehmussilta/Uusimaa Occupational Safety and Health Authority (07.12.2009).

473 Written answers to questions received from Maarit Lehmussilta/Uusimaa Occupational Safety and Health Authority (07.12.2009).

474 Spain/Ley orgánica 4/2000 (11.01.2000).
} 
third party company and the employment agency. This amendment, which the Senate still has to approve, aims to strengthen the protection of both legally and illegally employed persons, who, for recovery of their payments, can, under the new arrangement, choose to invoke the liability of either the employment agency or the third party company.

It is also particularly important that supporting illegally-staying foreigners in filing claims against their employer will not be considered a criminal offence in the domestic legislation transposing Council Directive 2002/90/EC of 28 November 2002 defining the facilitation of unauthorised entry, transit and residence, ${ }^{475}$ as made clear by Article 13(3) of Directive 2009/52/EC. In Germany, ambiguity in the domestic legislation was removed, through an amendment to para. Vorb.95.1.4 of the new general administrative regulation on the Residence Act. ${ }^{476}$

\section{The Blue Card Directive}

Directive 2009/50 on admission of highly-skilled migrants (the 'Blue Card' Directive) ${ }^{477}$ must be transposed by Member States by 19 June 2011 (Article 23(1)). ${ }^{478}$ The Directive sets minimum standards for the admission of highlyskilled migrants for "highly qualified employment", the criterion being that the job concerned must be paid at a rate of at least 1.5 times the average gross annual salary in the Member State concerned - although Member States can set a higher salary threshold for all sectors, or a lower threshold of 1.2 times the average annual salary in selected sectors (Article 5).

\section{Common European Asylum System}

In December 2008, the Commission proposed the first three measures to establish the second phase of the Common European Asylum System. ${ }^{479}$ First, the proposal amending the new Eurodac Regulation ${ }^{480}$ extends its scope to include applicants for subsidiary protection, ensures that data protection concerns are better addressed and ends the 'blocking' of the fingerprints of persons who obtain refugee status, among a number of other technical changes. In September 2009, after a first reading of the European Parliament, the Commission submitted a revised version of the proposal, which would provide for the extension of access to Eurodac fingerprint data for law enforcement purposes (COM (2009) 342). At the same time, it submitted a proposed thirdpillar decision on the same issue (COM (2009) 344).

\footnotetext{
475 OJ L 328, 5.12.2002, p. 17.

476 Germany/ Bundesrat (2009) Allgemeine Verwaltungsvorschriften 2009 http://www.bundesrat.de/cln 090/SharedDocs/Drucksachen/2009/0601-700/66909, templateId=raw, property=publicationFile.pdf/669-09.pdf (22.10.2009). 
Second, the Commission proposal amending the 'Dublin Regulation ${ }^{481}$ extends its scope to cover applicants for subsidiary protection. The rules in relation to family members and unaccompanied minors would be amended, to benefit the persons concerned. There would be new rules on detention of persons under the Dublin procedure and a possibility of suspending transfers to a Member State in two cases, namely where that Member State is facing particular difficulties with regard to its reception capacities due to large numbers of asylum seekers and various other pressures, or when it does not comply with EU asylum standards as set out in the relevant instruments. The European Parliament voted its first reading on this proposal in May 2009, and discussions are continuing in the Council.

Third, the Commission proposed to amend the Directive on reception conditions for asylum-seekers. ${ }^{482}$ The proposal extends the scope of the Directive to cover applicants for subsidiary protection, it introduces new rules on detention, which draw on the UNHCR guidelines, ${ }^{483}$ and enhances standards as regards addressing the needs of vulnerable persons, access to employments, material support and health care. The European Parliament voted its first reading on this proposal in May 2009, and discussions are continuing in the Council.

In February 2009, the Commission proposed a Regulation establishing a European Asylum Support Office, ${ }^{484}$ which was adopted by the Council at its meeting of $30^{\text {th }}$ November $-1^{\text {st }}$ December $2009^{485}$ and approved by the European Parliament in its second reading on 18 May 2010. The Office will play a role in facilitating the application of EC law, for example by disseminating country of origin information, and approximating Member States asylum practises, but it will not have a role in individual decision-making. The office is to be fully operational one year after the entry into force of the relevant Regulation.

In September 2009, the Commission proposed amendments to the European Refugee Fund relating to an EU resettlement programme. ${ }^{486}$ This would be a voluntary programme with extra financial support for Member States which participated by resettling refugees directly from third states. Discussions in the European Parliament and the Council are ongoing.

481 Council Regulation (EC) No 343/2003 of 18 February 2003 establishing the criteria and mechanisms for determining the Member State responsible for examining an asylum application lodged in one of the Member States by a third-country national, OJ 2003 L 50.

482 Directive 2003/9, OJ 2003 L 31/18.

483 See UN High Commissioner for Refugees, UNHCR's Revised Guidelines on Applicable Criteria and Standards relating to the Detention of Asylum-Seekers, 26 February 1999, available at: http://www.unhcr.org/refworld/docid/3c2b3f844.html [accessed 8 January 2010].

${ }^{484} \mathrm{COM}(2009) 66$ and 67.

${ }^{485}$ See:

http://www.se2009.eu/en/meetings news/2009/11/30/agreement to place the european asyl um_support_office_in_malta

486 COM (2009) 456. 
Finally, on 21 October, the Commission issued two legislative proposals for amending respectively the Asylum Procedures and Qualification Directives,. Overall, both proposals can be welcomed from a fundamental rights perspective. They suggest among other things, a stronger wording as regards gender-based persecution, an approximation of rights between refugees and beneficiaries of subsidiary protection, the introduction of a general principle of automatic suspensive effect in line with developing case law and reducing the grounds on which an individual asylum interview can be omitted. ${ }^{487}$ Discussions in the European Parliament and the Council are ongoing.

In February 2009, the Court of Justice also gave its first judgment relating to the EU's Directive on the qualification of refugees and persons in need of subsidiary protection. ${ }^{488}$ The judgment concerned the definition of the notion of "a serious and individual threat", as stipulated in Article 15(c) of the Directive. In particular, the Court clarified that, in cases of indiscriminate violence, a person could qualify for subsidiary protection, even if it is not demonstrated that he/she was specifically targeted for reasons linked to his/her personal circumstances, depending on the seriousness of such violence.

\section{Return of illegally staying third-country nationals and transfers of persons falling under the Dublin Regulation}

Council Directive 2008/115/EC on common standards and procedures in Member States for returning illegally staying third-country nationals was adopted on 16 December $2008 .{ }^{489}$ In 2009 , a number of States have adopted measures transposing this instrument. The ECJ has issued a preliminary ruling on the interpretation of Article 15 which regulates the imposition of detention. ${ }^{490}$ In Bulgaria, amendments were made on 15 May 2009 to the Закон за чужденците в Република България [Foreigners in the Republic of Bulgaria Act] which introduced a maximum six-month period of detention of third country irregular immigrants, five-year term of entry bans and administrative court ex officio review of length of the detention after the six-month period is over. $^{491}$

In executing decisions to remove aliens from the territory or reject them at the border, the EU Member States remain bound by the non-refoulement obligation

\footnotetext{
487 See http://eur-lex.europa.eu/LexUriServ/LexUriServ.do?uri=COM:2009:0551:FIN:EN:PDF as regards the Qualification Directive and http://eurlex.europa.eu/LexUriServ/LexUriServ.do?uri=COM:2009:0554:FIN:EN:PDF on the Asylum Procedures Directive.

488 Case C-465/07 Elgafaji, judgment of 19 February 2009.

489 OJ L 348 of 24.12.2008.

490 See Kadzoev case at http://curia.europa.eu/jurisp/cgibin/form.pl?lang=en\&jurcdj $=$ jurcdj\&newform $=$ newform $\& d o c j=d o c j \& d o c o p=d o c o p \& d o c n o j$ $=$ docnoj\&typeord $=$ ALLTYP\&numaff $=\&$ ddatefs $=25 \&$ mdatefs $=11 \&$ ydatefs $=2009 \&$ ddatefe $=2$ \&mdatefe $=12 \&$ ydatefe $=2009 \&$ nomusuel $=\&$ domaine $=\&$ mots $=\&$ resmax $=100 \&$ Submit $=$ Reche rcher (19.01.2010).

$491 \mathrm{http}: / / \mathrm{lex} \cdot \mathrm{bg} / \mathrm{bg} / \mathrm{laws} / \mathrm{ldoc} / 2134455296$, http://www.bghelsinki.org/index.php?module=news\&lg=en\&id=2548 (12.01.2010).
} 
of Art. 33 of the Geneva Convention relating to the Status of Refugees and by their obligations under the European Convention on Human Rights. Italy in particular has been strongly criticised by UNHCR for the policy concerning forced returns of migrants coming from Libya and intercepted at sea. ${ }^{492}$ The principle of non-refoulement remains applicable on the high seas, thus barring the return of individuals to countries where they are at risk of persecution, torture, inhuman or degrading treatment or punishment. Italy's push back policy is the subject of a report of the CPT on a visit carried out in 2009 and published on 28 April 2010, in which the CPT urges the Italian authorities to substantially review forthwith the current practice of intercepting migrants at sea, so as to ensure that all persons within Italy's jurisdiction - including those intercepted at sea outside Italian territorial waters by Italian-controlled vessels - receive the necessary humanitarian and medical care that their condition requires and that they have effective access to procedures and safeguards capable of guaranteeing respect for the principle of non-refoulement ${ }^{493}$

This obligation in principle also applies where the removal would be to a State party to the ECHR, or to a State bound by the Dublin II Regulation, if there existed a risk of removal to a third country in violation of these provisions. ${ }^{494}$ In the case of K.R.S. v. the United Kingdom, the ECtHR had initially requested the UK, under Rule 39 of its Rules of Procedure, not to return the applicant, an Iranian national, to Greece, since the UNHCR had recommended that parties to the Dublin Regulation refrain from returning asylum seekers to Greece. Subsequently, however, the Court held the application inadmissible. While recognising the weight which was to be given to this evaluation by the UNHCR, the ECtHR noted that the applicant in the case before it was an Iranian national, and that "Greece does not currently remove people to Iran (...) so it cannot be said that there is a risk that the applicant would be removed there upon arrival in Greece". ${ }^{495}$ Consistent with this case-law, the Finnish Supreme Administrative Court held that deportation to Greece did not constitute a violation of ECHR Article 3. The case was decided despite the UNHCR position papers holding that there were serious deficiencies in the Greek asylum procedure. ${ }^{496}$ By contrast, in September 2009, the German Federal Constitutional Court stopped the return of an Iraqi asylum seeker to Greece based on the Dublin Regulation. ${ }^{497}$ In his 2009 Report on Greece, the Council of Europe Commissioner for Human Rights called on the Greek authorities "to proceed

492 http://www.unhcr.it/news/dir/26/view/558/stop-ai-respingimenti-in-libia-55800.html (17.09.2009).

493 CPT Report to the Italian Government on the visit carried out from 27 to 31 July 2009 (CPT/Inf (2010)14, published on 28 April 2010) http://www.cpt.coe.int/documents/ita/2010inf-14-eng.htm.

494 Eur. Ct. HR/T.I. v. the United Kingdom (dec.), no 43844/98, Reports 2000-III.

495 Eur. Ct. HR (4 ${ }^{\text {th }}$ sect.), K.R.S. v. the United Kingdom (Appl. No. 32733/08), decision of 2 December 2008.

496 Finland/Korkein hallinto-oikeus/KHO 2009:22 (26.02.2009), available in Finnish at: http://www.finlex.fi/fi/oikeus/kho/vuosikirjat/2009/200900440 (02.10.2009).

497 See http://www.bundesverfassungsgericht.de/entscheidungen/qk20090908_2bvq005609.html (19.01.2010). 
urgently, in collaboration with competent national and international organizations, to a serious overhaul of the needs and prospects of the national asylum system in order for it to attain a quality level that would effectively safeguard the human rights of all persons in need of international protection." $" 498$

\subsubsection{Good Practices}

\section{Integration and diversity}

In Spain, the Autonomous Community of Valencia has passed the Law 15/2008 of 5 December 2008 on the Integración de las personas inmigrantes en la Comunidad Valenciana [Integration of immigrants in the Autonomous Community of Valencia]. ${ }^{499}$ The Law defines rights and obligations for immigrants taking into account the cultural and religious identity of the newcomers. It includes the so-called compromiso de integración [commitment to integration] that allows the immigrant to take a voluntary course, which includes information and basic knowledge through a specific programme, to gain a better understanding of the Valencian society. A person who undertakes the program will receive a certificate, which can be used in his/her social and legal relations in Valencia. Similarly in Luxembourg, a law concerning the hosting and integration of foreigners came into effect on 1 June 2009. It provides that a contract is proposed for those who intend to stay in Luxembourg over the long term, under which the Luxemburg State commits to providing language training and civics education. Luxembourg also has in place a national plan for integration and to fight against discrimination.

In Spain, the NGO Red Acoge [Reception Net] published in 2009 a Guide to deal with cultural diversity in enterprises, providing advice to companies about diversity issues. In Sweden, the Government in 2008 presented a comprehensive integration strategy Egenmakt mot utanförskap - regeringens strategi för integration for the years 2008-2010, listing seven strategic areas for integration and a number of specific measures in these areas aimed at promoting the integration of new immigrants. In 2009 the Government presented a Bill for faster introduction of new arrivals to working and social life. The incentives for both activity and work will increase, and the division of responsibility between agencies will be clarified. The aim is that the skills of the new arrivals will be utilised better than before. ${ }^{500}$ Smaller-scale projects also can have an important positive impact. In Sweden, a new project called Perrongen (The Platform) has

498 Report by Thomas Hammarberg, Council of Europe Commissioner for Human Rights, following his visit to Greece, 8-10 December 2008. CommDH(2009)6. Available at: https://wcd.coe.int/ViewDoc.jsp?id=1401927\&Site=CommDH\&BackColorInternet=FEC65B \&BackColorIntranet=FEC65B\&BackColorLogged $=$ FFC679

499 http://www.boe.es/boe/dias/2009/01/10/pdfs/BOE-A-2009-442.pdf (01.10.2009).

500 The proposal suggests the introduction of "establishment guides" and giving the National Public Employment Agency (Arbetsförmedlingen) responsibility for planning and executing an establishment plan for newly arrived immigrants when a residence permit is granted. See: http://www.regeringen.se/sb/d/10332/a/111563 (02.06.2009). 
started in the municipality of Örebro for newly arrived refugee children, providing these children with educational opportunities. ${ }^{501}$

\section{Financial programmes and dissemination of information}

In Spain, the Council of Ministers held on the 6 of March 2009 agreed to subsidise 15 million euros for the care of unaccompanied foreign minors. This grant is specifically aimed at the Canary Islands as a result of the massive influx of children from African countries to these islands. ${ }^{502}$

In the Czech Republic, the Ministry of Interior developed a programme to reduce the number of third country nationals overstaying in the country after losing their jobs in connection with the global economic crisis. The programme provided for the financing of a return to the country of origin, as well as an allowance in the amount of $€ 500$ for an adult and $€ 250$ for a child under 15 , and emergency accommodation for the period from registration until exit from the Czech Republic, including basic food. Up to July 2009 only foreigners who had been legally present in the Czech Republic were allowed to enter the project. In September 2009 a second project was started, aimed at irregular migrants and lasting only three months. ${ }^{503}$

The information provided to asylum seekers must ensure that they fully understand the procedure for the granting of asylum, and their rights and obligations while waiting for a decision on their application. In Italy, UNHCR, acting with ASGI (Associazione Studi Giuridici sull'Immigrazione) and SPRAR (Sistema di protezione per richiedenti asilo e rifugiati) and in collaboration with the authorities, published a new handbook which includes all the useful information and legal advice for asylum seekers, making this available in 10 languages. ${ }^{504}$

$501 \mathrm{http}: / /$ www.sr.se/orebro/nyheter/artikel.asp?artikel=3130764 (28.09. 2009).

502 http://www.lamoncloa.es/ConsejodeMinistros/Referencias/ 2009/refc20090306.htm\#Canarias (01.10.2009).

503 More information available on website of Ministry of Interior, http://www.mvcr.cz/clanek/pokracovani-projektu-dobrovolne-navraty-cizincu.aspx (30.09.2009).

504 http://www.interno.it/mininterno/export/sites/default/it/assets/files/16/0104 SPRAR Vademecum.pdf (17.06.2009) 


\subsection{Visa and border control}

\subsubsection{Legal developments}

\section{Biometric visas, passport security, visa code and visa blacklist}

The areas of visa and border control are again areas in which the EU has been developing an intensive legislative activity in 2009. On 23 April 2009, the Council and EP adopted Regulation 390/2009 on biometric visas and visa application centres. ${ }^{505}$ This Regulation governs the process of applying for biometric visas and sets out exceptions from the obligation to supply fingerprints, most notably for children under 12 .

Shortly afterwards, the Council and Parliament adopted Regulation 444/2009 amending Regulation 2252/2004 on passport security measures. ${ }^{506}$ This Regulation introduced exceptions to the obligation to take fingerprints of EU passport applicants, particularly for children under 12, although Member States may retain fingerprinting of 6-12 year olds for a limited period.

The generalisation of the collection of fingerprints for EU passport applicants led to concerns being expressed as to potential abuses by law enforcement authorities using the fingerprint register for routine inquiries linked to law enforcement. It is noteworthy that in Finland, while the original bill presented to Parliament amending the Passport Act and related laws authorised the police to access the fingerprint register for identification of persons if identification was "necessary for carrying out the tasks of the police", Parliament changed the relevant provisions after hearing the Constitutional Law Committee of Parliament. In the final text as adopted, the police may access the fingerprint data only if this is necessary for an identification of a victim of a natural disaster, a major accident or other catastrophe or a crime or for the purpose of identification of an otherwise unidentifiable victim. ${ }^{507}$

Next, in June 2009 the European Parliament and Council adopted Regulation $810 / 2009$ establishing a Visa Code. ${ }^{508}$ The Regulation replaces the Common Consular Instructions, the Schengen Convention measures (including implementing Decisions) relating to visas and some EC secondary legislation

\footnotetext{
505 Regulation (EC) No 390/2009 of the European Parliament and of the Councilof 23 April 2009 amending the Common Consular Instructions on visas for diplomatic missions and consular posts in relation to the introduction of biometrics including provisions on the organisation of the reception and processing of visa applications, OJ 2009 L 131 of 28.5.2009, p. 1.

506 OJ 2009 L 142/1.

507 See the amendment of the Passport Act and related laws [laki passilain ja eräiden siihen liittyvien lakien muuttamisesta/lag om ändring av passlagen och av vissa andra lagar som har samband med den (456/2009)]: http://www.finlex.fi/fi/laki/kokoelma/2009/20090073.pdf (02.10.2009)

508 OJ 2009 L 243/1.
} 
relating to visas, including Regulation 390/2009, as from 5 April 2010. Most notably, the visa code introduces the obligation to inform visa applicants of the decision on their application, and the reasons for any refusal, and to give a right of appeal against a negative decision (from 5 April 2011). There are also provisions relating to information for the general public on the visa application process, time periods for waiting before a visa application, and time periods for making decisions on an application. The list of countries where all Schengen visa applications are all subject to prior consultation by certain Member States will be made public for the first time.

In July 2009, the Commission proposed that several countries in the Western Balkans (Serbia, Montenegro, and the Former Yugoslav Republic of Macedonia) be moved from the EC's visa blacklist to its whitelist (COM (2009) 366). In December 2009, the Council adopted Regulation 1244/2009 correspondingly amending Regulation (EC) No 539/2001 listing the third countries whose nationals must be in possession of visas when crossing the external borders and those whose nationals are exempt from that requirement. ${ }^{509}$

The Immigration Act 2004 (visas) Order 2009, which came into effect on July $1^{\text {st }}$, sets out the nationalities of those who are not obliged to have a visa before travelling to Ireland, including EU nationals, as well as the nationalities of people who are required to have a transit visa when travelling through Ireland to another country. The order specifies that family members of EU nationals exercising Treaty rights in Ireland as workers, the self employed, students or economically self-sufficient persons who have been granted a residence permit or permanent residence permit in Ireland do not need to have a visa when travelling to Ireland.

\subsubsection{Good practices}

\section{Specific visa arrangements}

A problem in many EU Member States is that third-country nationals who need a visa in order to enter and remain on the national territory needed to return to their country of origin in order to obtain a renewal of their visa, at regular intervals - a complicated and costly process, which could create difficulties for regular employment, and which may be difficult to comply with for those who cannot leave the national territory because of their health condition or the medical treatment they are undergoing. In Austria, the Fremdenpolizeigesetz $2005^{510}$ (FPG) [Aliens' Police Act (APA)] was amended, with effect from 1 April 2009: according to Section 21 (9) APA, a visa can be issued to a foreigner who has legally entered the territory while he or she still has a valid residence title if this is required for further medical healthcare.

\footnotetext{
509 OJ 2009 L 336/1

510 Austria/BGB1 I 100/2005 (01.01.2006), last amended by Austria/BGB1 29/2009 (01.04.2009).
} 
Ireland launched a scheme for foreign nationals who have become undocumented through no fault of their own having previously possessed a work permit. The scheme, called "Towards 2016, Review and Transitional Agreement 2008-2009", 511 provides a facility for non EEA-nationals who previously had permission both to reside and work in the state but who became undocumented through no fault of their own but due to the conduct of their employer. A temporary immigration permission of four months is then issued within which time they must seek legitimate employment or seek an employment permit from the Department of Enterprise, Trade and Employment. The test is subjective and each case is measured on its merits.

Specific arrangements may have to be found for residents in countries whose nationals require a visa to enter the territory of an EU Member State, but who live nearby the border. On 22 July 2009 the Polish authorities started to issue permits allowing for "crossing a border within the small border movement". The document is issued by the Polish consular agencies in Ukraine. It costs 20 EUR and is valid for 2 years. It may be obtained by citizens of Ukraine, who live near the Polish border (in a zone of $30 \mathrm{~km}$ from the border) for at least 3 years.

\footnotetext{
511 Ireland/Department of the Taoiseach (2009) Towards 2016, Review and Transitional Agreement 2008-2009, available at: http://www.taoiseach.gov.ie/attached_files/Pdf\%20files/Taoiseach\%20Report_web.pdf $(25.09 .2009)$
} 


\section{Access to justice and victim compensation}

\subsection{Access to efficient and independent justice}

\section{Alternative dispute resolution and mediation}

Mediation is gaining an increased currency as a dispute resolution method, supported by European legislative developments. The Mediation Directive Directive 2008/52/EC of the European Parliament and of the Council of 21 May 2008 on certain aspects of mediation in civil and commercial matters ${ }^{512}-$ aims to facilitate access to alternative dispute resolution and to promote the amicable settlement of disputes by encouraging the use of mediation and by ensuring a balanced relationship between mediation and judicial proceedings. The Directive encourages training and quality control of mediators, it gives every judge the right to invite parties to mediation at any stage in the process, it requires mechanisms to be established that make mediated agreements enforceable, and the Directive requires mediation to be confidential and that judicial time limitations are suspended pending mediation. It also aims to make uniform across the Member States of the European Union the legal status of certain principles of the mediation practice.

Although not related to the Mediation Directive (which aims to solve crossborder litigations only) in the UK in 2009 there was a mediation-related concern, centred on the activities of the Muslim Arbitration Tribunal (MAT), which was set up in 2007 under the Arbitration Act 2006. ${ }^{513}$ In June 2009, a report $^{514}$ raised questions about the appropriate scope of tribunals under the Arbitration Act, which were not intended to deal with criminal or family disputes such as divorce or childcare cases. The report expresses a concern that "the attempt to extend sharia arbitration to family disputes under the misleading title of mediation is a potential misuse of both arbitration and family law."

\footnotetext{
512 OJ L 136 of 24.5 .2008 , p. 3. see http://eur-lex.europa.eu/LexUriServ/LexUriServ.do?uri=OJ:L:2008:136:0003:0008: EN:PDF

513 United Kingdom/Advise Services Alliance (2009) Recent Developments in Alternative Dispute Resolution, Update No. 28, August 2009, available at: http://www.asauk.org.uk/fileLibrary/pdf/adr28001.pdf (20.10.2009).

$514 \mathrm{http}: / /$ www.civitas.org.uk/pdf/ShariaLawOrOneLawForAll.pdf (20.10.2009).
} 
In Ireland, the Law Reform Commission's (LRC) Consultation Paper on Alternative Dispute Resolution (ADR) ${ }^{515}$ examines the growing use of ADR both internationally and in Ireland as reflecting the increasing number of options available to help resolve civil disputes. The LRC recommends, amongst other things, that mediation be statutorily defined.

In Austria, mediation in civil law procedures has been introduced as an alternative way to conflict resolution by the Federal Act on Mediation in Civil Law Procurements. ${ }^{516}$ The law regulates qualification criteria for mediators according to which mediators have to be above the age of 28 , professionally qualified (defined by law), confidential and have contracted a professional liability insurance. Mediators fulfilling these criteria can apply for being included in a list of mediators administered by the Federal Ministry of Justice, which can be easily accessed by web. ${ }^{517}$ The law furthermore defines the requirements for a suspension of legal time limits for civil law court cases by mediation procedures. Agreements in civil law areas made by way of mediation are legally binding (Mediationsvereinbarung).

\subsubsection{Legal developments}

\section{Fair trial and effective remedy}

The requirements of Articles 6 (fair trial) and 13 (effective remedy) of the European Convention on Human Rights were clarified in a number of cases presented to the ECtHR. In the case of Anakomba Yula a request for legal aid had been dismissed on the ground that the applicant was unlawfully resident in Belgium and that her action was not aimed at regularising her situation. In the circumstances of the case the Strasbourg Court found that there had not been particularly compelling reasons to justify the difference in treatment between individuals with a residence permit and those without one. A violation of Article $6 \S 1$ ECHR, taken together in conjunction with Article 14 ECHR, was found. ${ }^{518}$

In the case of Micallef, the Grand Chamber of the ECtHR dealt with an alleged lack of independence and impartiality of a domestic court hearing injunction proceedings. Previous case-law suggested that guarantees inherent in the right to a fair trial do not apply to proceedings that concern interim or provisional measures, since such proceedings are not normally considered to "determine" civil rights and obligations, and irregularities might be remedied in subsequent

\footnotetext{
515 LRC Consultation Paper on Alternative Dispute Resolution, http://www.lawreform.ie/publications/Consultation\%20Paper\%20on\%20ALTERNATIVE\%2 0DISPUTE\%20RESOLUTION\%20LRC\%20CP\%2050-2008.pdf (05.12.2009).

516 Bundesgesetz über Mediation in Zivilrechtssachen (Zivilrechts-Mediations-Gesetz ZivMediatG), BGBl. I Nr. 29/2003.

517 http://www.mediatorenliste.justiz.gv.at/ (15.09.2009).

518 ECtHR/Anakomba Yula v. Belgium (10.03.2009), Appl. No. 45413/07.
} 
main proceedings. However, the Grand Chamber noted the emergence of a widespread consensus amongst Council of Europe member States regarding the applicability of Article 6 to interim measures, including injunction proceedings. In this connection reference was also made to Article 47 of the EU Charter of Fundamental Rights and case-law of the Court of Justice. The Strasbourg Court observed that - in circumstances where many Contracting States face considerable backlogs in their overburdened justice systems leading to excessively long proceedings - a judge's decision on an injunction would often be tantamount to a decision on the merits of the claim for a substantial period of time, or even permanently in exceptional cases. The Court therefore considered that a change in the existing case-law was necessary. Article 6 would be applicable if the right at stake in both the main and the injunction proceedings was "civil" within the meaning of Article 6 and the interim measure determined the "civil" right at stake. However, the Court accepted that in exceptional cases it might not be possible to comply with all of the requirements of Article 6, though the independence and impartiality of the tribunal or the judge remained an inalienable safeguard. ${ }^{519}$

The Grand Chamber of the ECtHR also revised existing case-law in Scoppola (No. 2). Relying again on changing opinions amongst States parties and on international developments, the Grand Chamber ruled that Article 7 ECHR guarantees not only the principle of non-retroactivity of more stringent criminal laws but also, and implicitly, the principle of retroactivity of the benefit of the more lenient law. Express reference was made to the judgment of the ECJ in Berlusconi, Case C-387/02 a.o., 3 May 2005..$^{20}$

\subsubsection{Good practices}

An issue which will gain increased importance in the future, particularly as a result of the entry into force of the Convention on the rights of persons with disabilities, is that of the accessibility of judicial remedies for persons with disabilities, and the accommodation of their specific needs. In Austria, recent amendments of the Zivilprozessordnung (ZPO) [Act on Civil Procedures], aim at easing access to rights. Court hearings are improved for recourse proceedings. Deaf people and people with hearing impairments are provided with interpreters paid by the Federal State for proceedings as well as for the dialogue with their lawyers (insertion of Article 73a).The amendments entered into force on 1 April 2009. ${ }^{521}$

\footnotetext{
519 ECtHR/Micallef v. Malta (15.10.2009), Appl. No. 17056/06; link: ECHR Portal Search http://cmiskp.echr.coe.int/tkp197/search.asp?skin=hudoc-en (19.01.2010).

520 ECtHR, Scoppola (No. 2) v. Italy (17.09.2009), Appl. No. 10249/03.

521 Austria/Zivilverfahrens-Novelle 2009 - ZVN 2009. http://www.parlinkom.gv.at/PG/DE/XXIV/I/I_00114/fname_151558.pdf\#search="zivilprozes sdnung" (15.09.2009).
} 


\subsection{Compensation of victims}

\subsubsection{Legal developments}

\section{Transposition of Directive 2004/80/EC}

Council Directive 2004/80/EC of 29 April 2004 relating to compensation to crime victims $^{522}$ sets up a system for cooperation to facilitate access to compensation for victims of crime in cross-border situations. In a report published in April 2009, the European Commission sought to evaluate the transposition of this instrument and the outstanding challenges. ${ }^{523}$ Concerning the national compensation schemes required by the Directive, the report found that Member States provide fair and appropriate compensation for victims of violent intentional crimes and comply, broadly, with the requirements of the Directive. This is hardly surprising for the EU Member States that are parties to the 1983 European Convention on the Compensation of Victims for Violent Crimes. ${ }^{524}$ The assessment is much less positive about the procedural aspects of the Directive for cross-border cases, particularly about the information of potential claimants about their rights and the effectiveness of the procedures. However, apart from the fact that certain developments have been occurring since the evaluation was made, ${ }^{525}$ the evaluation contained in the Commission report has been questioned by some authorities. For instance, in Austria, the Federal Social Services Department remarked that the collection of data in this regard proves to be relatively complex because the formalised procedure of Section 9a Verbrechensopfergesetz (VOG) [Victims of Crime Act (VCA)] ${ }^{526}$ was applied only in a very small percentage of all cases with extraterritorial dimension: indeed, many victims or their legal representatives prefer to directly approach the authorities without the formalised procedure which would register the cases as ones where the Directive is applied. In Greece, legislation has been

\footnotetext{
522 OJ 2004 L 261, p. 15.

${ }^{523} \mathrm{COM}(2009) 170$ final of 20.4.2009. The report was based on empirical studies commissioned to Matrix Knowledge Group, published in January 2009, http://ec.europa.eu/justice_home/doc_centre/civil/studies/doc/study_compensation_to_crime victims en.pdf.

524 CETS No. 116, signed on 24.11.1983 and in force since 1.2.1988. Seventeen EU Member States are parties to this instrument. Three have signed it but have failed to ratify it (Greece, Hungary and Lithuania). Seven EU Member States have not signed the convention: these are Bulgaria, Ireland, Italy, Latvia, Malta, Poland and Slovenia.

525 In Portugal, Law 14/2009 was adopted on 14 September 2009, creating a Commission for the Protection of Victims of Crimes (article 7): http://www.dgpj.mj.pt/sections/leis-da-justica/pdfult2/lei-n-104-2009-de-14de/downloadFile/file/lei\%20104.2009.pdf?nocache=1252915827.42 (15.10.2009). In the United Kingdom, a Criminal Injuries Compensation Scheme [http://www.cica.gov.uk/TopNavigation/Publications/ (16.10.2009)] and a Criminal Injuries Compensation Scheme 2009 were adopted, respectively for Great Britain and Northern Ireland.

526 Austria/BGB1 288/1972 (01.09.1972), last amended by Austria/BGB1 I 40/2009 (01.06.2009).
} 
adjusted to the Council Directive 2004/80/EC of 29 April 2004 relating to compensation for crime victims. ${ }^{527}$

\section{Standing of victims in criminal proceedings}

The implementation of the Council Framework Decision of 15 March 2001 on the standing of victims in criminal proceedings ${ }^{528}$ was also recently evaluated in a report from the Commission adopted pursuant to Article 18 of the Framework Decision. ${ }^{529}$ The conclusion was particularly straightforward:

"The implementation of this Framework Decision is not satisfactory. The national legislation sent to the Commission contains numerous omissions. Moreover, it largely reflects existing practice prior to adoption of the Framework Decision. The aim of harmonising legislation in this field has not been achieved owing to the wide disparity in national laws. Many provisions have been implemented by way of non-binding guidelines, charters and recommendations. The Commission cannot assess whether these are adhered to in practice."

Some developments concerning the implementation of the Framework Decision were reported after closing this evaluation. In Italy, victims of sexual or certain violent abuses have been allowed to provide their testimony in a pre-trial phase within a protected space, in the presence of both counsels for prosecution and defence but in the absence of the accused, and without having to reiterate the testimony in court. ${ }^{530}$ The same law provides free legal aid for victims of rape or other sexual crimes. Luxembourg ${ }^{531}$ and Germany ${ }^{532}$ also significantly improved the protection of victims of criminal acts in their legislation. However, according to the above mentioned report from the Commission, the overall level of implementation remains very weak.

\section{Victims of human trafficking}

Regarding the compensation of victims of human trafficking, some positive developments can be reported. Some of these concern the right to compensation for the victims of human trafficking, particularly in countries that have ratified the Council of Europe Convention on action against trafficking in human

\footnotetext{
${ }^{527}$ Law 3811/2009 (Official Journal 231/A/18.12.2009

528 2001/220/JHA

$529 \operatorname{COM}(2009)$ I66 final, 20.4.2009.

530 Italy/Decreto legge 11/2009, as modified by Italy/legge 38/2009, ${ }^{530}$ introduced articles 392 par. 1-bis and 398 par. 5-bis in the Criminal Procedure Code,

531 Luxembourg/Loi du 6 octobre 2009 renforçant le droit des victimes d'infractions pénales (06.10.2009), Mémorial A-N ${ }^{\circ} 206,19.10 .2009$, p. 3538. Available in French at: http://www.legilux.public.lu/leg/a/archives/2009/0206/a206.pdf\#page=2 (23.10.2009).

532 Gesetz zur Stärkung der Rechte von Verletzten und Zeugen im Strafverfahren (2. Opferrechtsreformgesetz) vom 29. Juli 2009, in Kraft getreten am 1. Oktober 2009, Bundesgesetzblatt 2009 Teil I Nr. 48, S. 2280. Available in German at: http://www.bmj.bund.de/files/4dfdc5d9f62707a7e6cdd9676b7665c0/3838/gesetz_zweites_op ferrechtsreformgesetz bundesgesetzblatt.pdf
} 
beings $^{533}$ (Warsaw Convention) or the Palermo Protocol of the UN Convention against transnational organised crime to prevent, suppress and punish trafficking in persons, both of which provide for such compensation. For instance, in March 2009 Luxembourg's Chamber of Deputies voted into law Bill No. 5874 on assistance and protection to victims of human trafficking, which provides for social and financial assistance to victims. An OSCE study made public at the beginning of 2009 provides a brief analysis of the legal and institutional framework in relation to compensation for victims of trafficking and exploitation, and an assessment of state compensation schemes as well as of the efficiency of compensation awarded by civil, criminal or labour courts. ${ }^{534}$

\subsubsection{Good Practices}

\section{Information and services to victims}

The question of the quality of the information provided to victims is a major concern in this area, particularly as regards cross-border situations. Regional initiatives, covering areas in which the movement of persons is particularly important, may be an interesting option. In May 2009, the Inter-Regional Crime Prevention working group of the Grande Région (Luxembourg, France, Germany, ${ }^{535}$ Belgium) published a basic information guide for victims, detailing what to do in the event one is a victim of a crime or an accident. ${ }^{536}$

In July 2004, a natural gas leak in Ghislenghien, Belgium, caused an explosion, resulting in the death of 24 people and the injury of many more. The insurance companies covering the civil liability of the parties under judicial investigation for this catastrophe decided in May 2009 to propose a compensation for the victims without awaiting the outcome of the complex judicial proceedings. The Minister of Justice announced that he would present a bill creating the

\footnotetext{
${ }^{533}$ Article 15 of the Council of Europe Convention provides for the right of victims to compensation from the perpetrators, and requests Parties to adopt measures to guarantee compensation for victims, in accordance with the conditions under their internal law

534 OSCE/ODIHR (2008) Compensation for Trafficked and Exploited Persons in the OSCE Region, http://www.osce.org/publications/odihr/2008/05/31284_1145 en.pdf(17.09.2009).

535 Germany provides leaflets to victims of crime on their rights during criminal proceedings in many languages, including almost all European languages as well as Arabic and Vietnamese. http://www.justiz.nrw.de/opferschutz/allgemeine informationen/opferschutz strafverfahren/a vr 32/index.php

536 Available at:

http://www.granderegion.net/fr/cooperation-politique-interregionale/architectureinstitutionnelle/groupes-communautes-

travail/prevention_criminalite/DEPLIANT_PREVENTION.pdf (22.10.2009). See also the Grande Région's website which contains German-language information on the same topic at: http://www.granderegion.net/fr/cooperation-politique-interregionale/architectureinstitutionnelle/groupes-communautes-travail/prevention_criminalite/index.html $(22.10 .2009)$.
} 
framework for the accelerated compensation of victims in the case of future disasters. ${ }^{537}$

In Ireland, the Victims of Crime Office ${ }^{538}$ works to support the development of competent and efficient services for victims of crime. It seeks to improve the continuity and quality of services for victims of crime, by state and voluntary agencies and non-governmental organisations throughout the country. Some of its main priorities are: using the Victims' Charter to achieve improved standards of treatment of victims by relevant State and voluntary sector organisations promoting awareness concerning the needs of victims of crime; advising the Minister for Justice, Equality and Law Reform on victim issues in Ireland and on any international developments; working in cooperation with $\operatorname{COSC}^{539}$, the Anti-Human Trafficking Unit, the Criminal Law Reform Division and all other relevant sections of the Department of Justice.

\footnotetext{
537 Belgium/Ministry of Justice, Press Release (11.05.2009). Available at: http://www.just.fgov.be/persberichten/2009/05/11.html (Dutch) (08.10.2009) and http://www.just.fgov.be/communiques/2009/05/11.html (French) (08.10.2009).

$538 \mathrm{http}: / /$ www.victimsofcrimeoffice.ie (29.09.2009).

539 The National Office for the Prevention of Domestic, Sexual and Gender-Based Violence, www.cosc.ie (20.09.2009).
} 


\section{Participation of the citizens of the Union in the Union's democratic functioning}

\section{Dialogue, transparency, electoral turnout and right to vote}

The Stockholm Programme - An open and secure Europe serving and protecting the citizens was adopted by the European Council of 11-12 December. ${ }^{540}$ It encourages the EU institutions to strengthen civil dialogue with representative organisations and civil society (1.2.8.). It also requests the Commission to examine how best to ensure transparency of decision-making, access to documents and good administration of justice in the light of the opportunities created by the Lisbon Treaty, referring in that respect in particular to the European Citizens' Initiative introduced by Article 11 TEU (2.6.). The European Council also regretted that the turnout to the European elections dropped by 20 per cent since 1979, when the first elections to the European Parliament with universal suffrage were held. This calls for improving the quality of the information given to the citizens.

In Ireland, the Government took a decision in April 2009 to close down the National Forum on Europe in a further effort to curtail public expenditure. The Forum was established in 2001 to facilitate debate on Ireland's membership of the European Union following a negative vote in the first Nice Treaty referendum. Its role, however, will be taken over by the Oireachtas SubCommittee on Ireland's Future in Europe. (See also the 'eu.matters.ie' website referred to in section 8.2.)

Another issue raised during the European elections was that of the accessibility for voters with disabilities. In Poland, blind citizens filed a claim on 17 June 2009, stating that the polling stations were not technically adjusted for the persons with visual impairment. In order to vote, blind persons had to be assisted by a third person (very often an employee of the voting committee) who filled out the ballot paper according to their instruction. In their opinion a blind voter should be able to vote alone and in secrecy using Braille language. The claimants considered that the lack of technical adjustment and the necessity to be assisted by third persons violate their constitutional right for a secret ballot. Although the claim was rejected by the Polish Supreme Court, ${ }^{541}$ the accession of the European Union to the UN Convention on the rights of persons

\footnotetext{
540 For the context in which the programme was adopted, see: http://www.se2009.eu/en/the presidency/about the eu/justice and home affairs/1.1965; for the text, see: $\mathrm{http}: / /$ register.consilium.europa.eu/pdf/en/09/st17/st17024.en 0 (01.01.2010).

541 Text of the judgment is available at: http://www.sn.pl/orzecznictwo/uzasadnienia/ipusisp/III_SW 0048 09.pdf (12.01.2010).
} 
with disabilities should lead EU Member States to pay greater attention to these issues in the context of European elections.

\subsection{Legal developments}

Council Directive 93/109/EC of 6 December 1993 lays down detailed arrangements for the exercise of the right to vote and to stand as a candidate in elections to the European Parliament for citizens of the European Union residing in a Member State of which they are not nationals. Certain difficulties seem to remain, such as the implementation of the measures aiming at ensuring that no EU citizen is registered to vote in more than one State. As regards the possibility for non-nationals who are EU citizens to be candidates at elections to the European Parliament too, obstacles exist. In Austria, the Green Party reported a number of legal and practical obstacles in the implementation of the right to be elected of EU citizens, particularly regarding the receipt of an 'eligibility certificate' of the authorities of other Member States. The Commission proposed a legislative proposal in 2006 to modify Council Directive 93/109/EC and simplify the procedural aspects ${ }^{542}$.

\subsection{Good practices}

\section{Citizen's summit, vote from abroad, communication facilities}

On the $10^{\text {th }}$ and $11^{\text {th }}$ of May 150 citizens from all European Member States who took part in a pan-European debate on how to confront the economic and social challenges facing Europe met with policy makers in Brussels to hand over the recommendations at the 2009 European Citizen's summit. The final list of recommendations can be accessed at www.european-citizens-consultations.eu.

In Cyprus, the Internal Affairs committee of the House of Representatives decided on 5 May 2008 that, in the absence of any constitutional barrier, it would establish electoral centres outside Cyprus to enable Cypriots temporarily residing abroad to vote in the European elections of 7 June 2009. A number of voting centres were established in countries with a significant Cypriot presence and Cypriots residing abroad temporarily were able to vote in the European Parliament elections, without the political parties being obliged to fly their voters from abroad to Cyprus in order to vote. Romania also opened 294 electoral offices abroad (out of which 55 in Italy and 38 in Spain), in order to facilitate participation of Romanian voters to the elections of the European Parliament. ${ }^{543}$

542 COM 2006(791), 12 December 2006.

543 Information available at: http://www.mae.ro/index.php?unde=doc\&id=38838 (12.01.2010). 
In June 2009, the Irish government launched a public information website called 'eumatters.ie" ${ }^{, 544}$ which has been designed to facilitate queries from Irish citizens about the European Union. Independent research carried out in 2007 indicated that Irish people's knowledge of the EU was substantially lower than those of other Member States. The website is part of the Department of Foreign Affairs Communicating Europe Initiative (CEI) which has been operating since 1995, and which aims to raise public awareness of the EU and of Ireland's membership.

544 www.eumatters.ie 


\section{Information society, respect for private life and protection of personal data}

\section{Policy and research developments, opinions and reports}

The Stockholm Programme, referred to above, calls for the introduction of a comprehensive protection scheme regarding privacy and personal data protection. In particular, according to the Programme, the Union must secure a new comprehensive strategy to protect citizens' data within the EU and in its relations with other countries. In addition it must improve compliance with the data protection principles through the development of appropriate new technologies and raise awareness among the public. It must also foresee and regulate the circumstances in which public authorities might need to restrict the application of these rules in the exercise of their lawful duties. On a broader front, the Union must be a driving force behind the development and promotion of international standards for personal data protection and in the conclusion of appropriate bilateral or multilateral instruments.

The European Commission arranged for a study, an Evaluation of the Means used by National Data Protection Supervisory Authorities in the promotion of personal Data Protection. ${ }^{545}$ This study identifies and examines in detail the means used by national Data Protection Supervisory Authorities (DPSAs) in promoting the protection of personal data in general, particularly by raising awareness. It assesses the promotional activities of DPSAs in seven Member States: France, Germany, Romania, Slovenia, Slovakia, Sweden, and the United Kingdom. Its conclusions are divided in seven categories based on the evaluation criteria used, namely, effectiveness, impact, efficiency, relevance and utility, added value, complementarity and sustainability. The Study recommends developing a more proactive and pragmatic approach; to make the best use of the power of the mass media; to target the education sector; to develop self-assessment strategies; to develop increased cooperation with other public bodies involved in data protection incidents, and to promote greater cooperation across Member States.

The European Parliament's LIBE Committee received a study dealing with the protection of fundamental freedoms on the internet and the fight against cyber

\footnotetext{
545 Evaluation of the Means used by National Data Protection Supervisory Authorities in the promotion of personal Data Protection (final report by KANTOR Management Consultants S.A. - Greece (Consortium Leader) on behalf of the European Commission), http://ec.europa.eu/justice_home/fsj/privacy/docs/studies/final_report_kantor_management_c onsultants.pdf (12.01.2010).
} 
crime. ${ }^{546}$ The study examines the human rights aspects of the internet and a number of other issues regarding cyber-crime, such as data protection rights, the EU's Safer Internet programme, child pornography, attacks on information systems, terrorism, racism and xenophobia. It highlights in particular that the right to privacy and the protection of personal data are, along with the freedom of expression, the most frequently invoked human rights in the context of the Internet. It concludes that the EU should adopt a non-binding Internet Bill of Rights; develop substantive and procedural criminal law regarding cybercrime; and develop operational action as regards cyber-crime.

On 26 March 2009, the European Parliament voted with a large majority to support the Lambrinidis report concerning the protection of individual liberties on the Internet, rejecting the amendments proposed by the French Government and the copyright industry. The position of the Parliament was that "guaranteeing Internet access to all citizens is the same as guaranteeing all citizens access to education" and that "such access must not be refused in punishment by governments or private organizations". ${ }^{547}$

The Article 29 Working Group established under the 1995 EU Data Protection Directive and composed of the EU Member State Data Protection Authorities (DPAs) adopted a report providing guidance and applicable rules both for service providers of "social networks" such as Facebook and for persons using these services in Opinion No. 5/2009 of 12 June 2009. This document focuses in particular on the greater protection which must be given to child users. It enumerates service provider obligations, valid even for service providers located outside the EU. ${ }^{548}$

The European Commission convened a Social Networking Task Force in 2008 with operators of social networking sites used by children, NGOs and researchers. As a result, 18 major social networks active in Europe signed a self-regulatory agreement, the "Safer Social Networking Principles for the EU"549 in February 2009. The document outlines the principles by which social networking providers should be guided as they seek to help minimise potential harm to children and young people, and recommends good practice approaches which can help achieve those principles. One of the principles is to "enable and encourage users to employ a safe approach to personal information and privacy". Two more signatories joined in June 2009. The European Commission

\footnotetext{
546 S. Peers (without year) Study for the Civil Liberties Committee (LIBE): Strengthening security and fundamental freedoms on the internet - an EU policy on the fight against cyber crime, http://www.europarl.europa.eu/activities/committees/studies/download.do?language $=$ en\&file $=24233 \#$ search $=\% 20$ cyber-crime $(12.01 .2010)$.

$547 \mathrm{http://www.edri.org/edri-gram/number7.7/ep-recom-human-rights-internet}$

548 http://ec.europa.eu/justice home/fsj/privacy/docs/wpdocs/2009/wp163_fr.pdf (22.10.2009).

549 Safer Social Networking Principles for the EU:http://ec.europa.eu/information_society/activities/social_networking/docs/sn_principles.p df
} 
commissioned a study to assess the implementation of this agreement by all signatories $^{550}$, which included testing of the websites from a user perspective.

The European Commission commissioned an independent study to develop a monitoring tool assessing risks for media pluralism in the EU Member States and identifying threats to such pluralism. The result of the study, the Media Pluralism Monitor (or MPM), adopts a broad notion of media pluralism encompassing political, cultural, geographical, structural and content related dimensions. It recognises that media of all types - public service, commercial and community media - play important roles in creating pluralism and that a range of media types and channels/titles are important for providing pluralism. At the same time, it also recognises different policy and regulatory approaches towards certain types of media (for example, broadcasting, print and new media) and such distinctions are reflected in the indicators. The Media Pluralism Monitor is designed as a diagnostic tool for obtaining a broad understanding of risks to media pluralism in a Member State, and does not set policy responses ${ }^{551}$.

In Ireland, in his Annual Report for 2008, ${ }^{552}$ the Irish Data Protection Commissioner focuses on the responsibility of the private and public sector organisations to treat the personal information of their customers and clients with respect. He noted an increase in the number of complaints related to access rights under the Data Protection Acts 1988 and 2003, reflecting a higher level of awareness among the public of their rights in this area.

\section{Data protection in employment}

Personal data protection in the context of employment also has been a concern for a number of years. Germany included basic principles of data protection for employees in the Federal Data Protection Act in 2009. ${ }^{553}$ In Finland, the laki sähköisen viestinnän tietosuojalain ja eräiden siihen liittyvien lakien muuttamisestallag om ändring av lagen om dataskydd vid elektronisk kommunikation (125/2009) [Act on the Protection of Privacy in Electronic Communications and related laws] entered into force in 2009. In order to prevent leaking of corporate secrets, the Act allows companies to monitor the addresses of e-mails sent and received by employees, as well as the type of attachments linked with the message, although not the content of the message itself. Despite critiques concerning the impacts on the protection of private life

\footnotetext{
550 Staksrud, E. and Lobe, B. (2010) Evaluation of the implementation of the Safer Social Networking Principles for the EU Part I: General Report. European Commission Safer Internet Programme, Luxembourg http://ec.europa.eu/information society/activities/social networking/eu action/implementatio n princip/index en.htm\#final report

$551 \mathrm{http} / / /$ ec.europa.eu/information_society/media_taskforce/pluralism/study/index_en.htm

552 Ireland/The Office of the Data Protection Commissioner (2009) Twentieth Annual Report of the Data Protection Commissioner 2008, available at: http://www.dataprotection.ie/documents/annualreports/AR2008.pdf (23.09.2009).

$553 \S 32$ Federal Data Protection Act; Bundesgesetzblatt Teil I Nr. 54 vom 19.8.2009, S. 2817.
} 
and personal data, the constitutionality of the Act was approved by the Constitutional Law Committee of Parliament in its opinion 29/2009. ${ }^{554}$ In Luxembourg, the Commission nationale à la protection des données [National Commission on Data Protection] released an online Guide about cybersurveillance in the workplace that provides information on legal requirements, rights and responsibilities. The CNPD website contains a fair amount of information on the various types of cyber surveillance, including information on what other countries are doing in that area, and on the Article 29 Working Group. The guide includes an authorisation request, with extensive information on how to prepare the request. ${ }^{555}$ In Slovakia, the Ministry of the Interior adopted an Ordinance on details of the camera security system. ${ }^{556}$ These developments point to the need for more clarity on the implications for personal data protection of new technologies, and on the best way to manage such implications.

\subsection{Legal developments}

\section{Amended proposal and Court of Justice case law}

On 25 November 2009, the European Parliament and the Council adopted the Telecom Reform package, which includes the Citizens' Rights Directive 2009/136/EC, ${ }^{557}$ amending Directives 2002/22/EC on universal service and users' rights relating to electronic communications networks and services and 2002/58/EC concerning the processing of personal data and the protection of privacy in the electronic communications sector (the ePrivacy Directive) and Regulation (EC) No 2006/2004 on cooperation between national authorities responsible for the enforcement of consumer protection laws, based on the Commission's proposals presented in 2007,. The amendments strengthen users' rights to transparency and control with respect to privacy and the protection of personal data in the electronic communications sector, and improve enforcement.

The European Court of Justice delivered a preliminary ruling on the interpretation of Article 12(a) of the Data Protection Directive. ${ }^{58}$ The Court held that Article 12(a) of the Directive requires Member States to ensure a right of access to information on the recipients or categories of recipient of personal data and on the content of the data disclosed not only in respect of the present

\footnotetext{
${ }^{554}$ http://www.finlex.fi/fi/laki/kokoelma/2009/20090024.pdf (02.10.2009).

555 CNPD website at: http://www.cnpd.lu/fr/autorisations/traitements da/surveillance/index.html, and http://www.cnpd.lu/en/autorisations/demande video/index.html (22.10.2009).

556 Slovakia/vyhláška 332/2009 (14.08.2009).

557 http://eur-lex.europa.eu/LexUriServ/LexUriServ.do?uri=CELEX:32009L0136:EN:NOT (OJ L 337 of 18.12.2009, p. 11)

558 Directive 95/46/EC of the European Parliament and of the Council of 24 October 1995 on the protection of individuals with regard to the processing of personal data and on the free movement of such data (OJ 1995 L 281, p. 31).
} 
but also in respect of the past. However, it is for Member States to fix a timelimit for storage of that information and to provide for access to that information which constitutes a fair balance between, on the one hand, the interest of the data subjects in protecting their privacy, in particular by way of their rights to object and to bring legal proceedings and, on the other, the burden which the obligation to store that information represents for the controller. According to the Court,

"rules limiting the storage of information on the recipients or categories of recipient of personal data and on the content of the data disclosed to a period of one year and correspondingly limiting access to that information, while basic data is stored for a much longer period, do not constitute a fair balance of the interest and obligation at issue, unless it can be shown that longer storage of that information would constitute an excessive burden on the controller. It is, however, for national courts to make the determinations necessary". 559

In Case C-557/07, the European Court of Justice was requested to provide an interpretation of the 1995 Data Protection Directive in the context of a civil proceeding between an Internet Service Provider (ISP) and a Collecting Society for copyrights, as the latter sought a legal order to obtain the name of a subscriber, based on the IP address of an internet user which was considered to have committed an infringement of copyright. The Court took the view that "Community law - in particular, Article 8(3) of Directive 2004/48/EC of the European Parliament and of the Council of 29 April 2004 on the enforcement of intellectual property rights, read in conjunction with Article 15(1) of Directive 2002/58/EC of the European Parliament and of the Council of 12 July 2002 concerning the processing of personal data and the protection of privacy in the electronic communications sector (Directive on privacy and electronic communications) - does not preclude Member States from imposing an obligation to disclose to private third parties personal data relating to Internet traffic in order to enable them to bring civil proceedings for copyright infringements". In its ruling the Court found that Directives 2000/31, 2001/29, 2004/48 and 2002/58 do not require the Member States to lay down, in a situation such as that in the main proceedings, an obligation to communicate personal data in order to ensure effective protection of copyright in the context of civil proceedings. The ruling added that:

"Community law nevertheless requires Member States to ensure that, when transposing into national law Directive 2000/31/EC of the European Parliament and of the Council of 8 June 2000 on certain legal aspects of information society services, in particular electronic commerce, in the Internal Market ("Directive on electronic commerce"), Directive 2001/29/EC of the European Parliament and of the Council of 22 May 2001 on the harmonisation of certain aspects of copyright and related rights in the

559 Case C-553/07, Rijkeboer, 7 May 2009. 
information society, and Directives 2002/58 and 2004/48, [the Member States] rely on an interpretation of those directives which allows a fair balance to be struck between the various fundamental rights involved. Moreover, when applying the measures transposing those directives, the authorities and courts of Member States must not only interpret their national law in a manner consistent with those directives but must also make sure that they do not rely on an interpretation of those directives which would conflict with those fundamental rights or with the other general principles of Community law, such as the principle of proportionality". 560

\section{Copyright, data retention and privacy}

Following this preliminary ruling, the Austrian Supreme Court decided in July 2009 on the question of whether the ISP is liable to provide the information about the name and the address of the user to whom a particular dynamic IPaddress had been allocated for a certain time if there is a reasonable suspicion of violating copyrights. ${ }^{561}$ Thus, the court found, although the Copyright Act stipulates in $\S 87 \mathrm{~b}$ a right to information about the subscriber, that the Austrian legal framework does not provide a legal basis for a retention of IP logs. Therefore the ISP is presently neither obligated nor allowed to provide the coveted information, even if it is available due to an illegal retention. It remains to be seen whether, once the Data Retention Directive (2006/24/EC) will have been transposed, the same solution will prevail.

In Sweden, the new IPRED law implementing Directive 2001/29/EC of 22 May 2001 on the harmonisation of certain aspects of copyright and related rights in the information society came into force on 1 April 2009. It gives copyright holders the right to seek a court order identifying people linked to illegal downloading. This means that internet providers can be forced by a court order to provide data about customers targeted in copyright infringement investigations. ${ }^{562}$

Ireland's request to annul the Data Retention Directive (2006/24/EC), on the ground that it was not adopted on an appropriate legal basis was rejected by the European Court of Justice. ${ }^{53}$ The transposition of the Directive was delayed by several Member States. The Commission launched infringement proceedings against Austria, Ireland, Greece and Sweden, and obtained favourable judgments from the ECJ against these Member States. In some Member States, the national legislation transposing the Directive was challenged on the grounds

\footnotetext{
560 Case C-557/07, LSG-Gesellschaft zur Wahrnehmung von Leistungsschutzrechten GmbH vTele2 Telecommunication GmbH, order of 19 February 2009.

561 Austria/Supreme Court (OGH)/4 Ob 41/09x (14.7.2009); available at http://www.ris.bka.gv.at/ (19.01.2010).

562 http://www.sweden.gov.se/sb/d/9338/a/85366 (04.05.2009).

563 The European Court of Justice held that the Data Retention Directive was properly adopted as an internal market measure (by qualified majority voting) rather than as a criminal matter (requiring unanimity). See Case C-301/06, Ireland $v$ European Parliament and Council of the European Union, judgment of 10 February 2009.
} 
of the doubts that remain concerning the implications of data retention for the right to respect for private life and personal data protection. In Romania the Constitutional Court found the national transposition law unconstitutional in its entirety $^{564}$ in the context of a case filed by an NGO against a telecommunications company on privacy grounds. ${ }^{565}$ Interestingly, in Austria, in April 2009, the Ludwig Boltzmann Institute of Human Rights ${ }^{566}$ was assigned by the Federal Ministry for Transport, Innovation and Technology to elaborate a draft act transposing the Data Retention Directive 2006/24/EC into national law, in order to find a way of transposition that interferes least with fundamental rights of users. In Germany the Federal Constitutional Court has also been requested to decide on the conformity with the German Constitution of the national law implementing the Data Retention Directive; the judgment was delivered on 2 March 2010. The Court declared the national data retention law unconstitutional in its present form. ${ }^{567}$

In Ireland, the Communications (Retention of Data) Bill 2009 published in July 2009 aims at giving effect to the EU Data Retention Directive 2006/24 EC. The draft law requires telecommunication companies and internet service providers to retain data on communications. It has created a certain degree of controversy on two different fronts. Firstly, those opposed to the Bill have claimed that data retention is a major invasion of privacy. Secondly, the legislation places data security and management requirements on service providers. This may involve significant costs which may ultimately be passed onto the customers of these services. Under the draft legislation phone traffic data can be retained for two years while internet data can be held for one year.

\section{Data protection in criminal investigations and surveillance}

A number of developments concern the protection of personal data used for criminal investigations and in criminal procedures. In Denmark, following the judgment of the ECtHR in the 2008 case of $S$. and Marper v. the United Kingdom, the rules pertaining to the storage by the police of DNA-profiles and fingerprints of acquitted persons are likely to be changed. In Germany, the Federal Constitutional Court held that it is unconstitutional to retain genetic fingerprints ${ }^{568}$ of convicted criminals based on Section 81 lit. $g$ of the Strafprozessordnung (StPO) [Criminal Procedure Code], without adequately considering their right to informational self-determination pursuant to Article 1 para 1 in conjunction with Article 2 para 1 . of the Basic Law. ${ }^{569}$ In Ireland, the

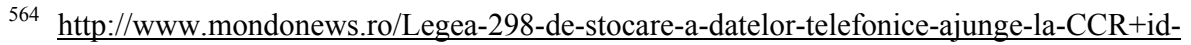
5439.html (07.09.2009).

565 Romania/Curtea Constituțională, File 788D of the Romanian Constitutional Court, available at: http://www.ccr.ro/sedinte/8septembrie.pdf (30.09.2009).

566 http://bim.lbg.ac.at/ (09.10.2009).

567 See: BVerfG, 1 BvR 256/08 vom 2.3.2010, Absatz-Nr. (1 - 345), http://www.bverfg.de/entscheidungen/rs20100302_1bvr025608.html

568 I.e. DNA.

569 Press release http://www.bundesverfassungsgericht.de/pressemitteilungen/bvg09-062.html (22.10.2009); and see:
} 
Criminal Surveillance Bill 2009 will provide, for the first time, a legal framework to allow covert surveillance material to be used in criminal trials. It provides that secret surveillance can be used either as evidence to support other direct evidence on criminal charges, or as a basis on its own for a charge of conspiracy.

In Sweden, a new surveillance law came into effect on 1 January 2009, giving the national defence's civilian agency National Defence Radio Establishment the right to tap all cross-border internet and telephone communications, a development denounced by civil liberties groups. ${ }^{570}$ Changes were made to the law in October 2009, mandating the government and the military to be responsible for asking the National Defence Radio Establishment to carry out surveillance, providing that judicial authorisation is required for each case of monitoring, and limiting eavesdropping to exceptional cases, ${ }^{571}$ Concerns were raised also following the adoption of legislation in Portugal making it obligatory to introduce electronic devices in all vehicle number plates, in order to improve the fight against carjacking. ${ }^{572}$

\subsection{Good practices}

In Ireland, a Data Protection Audit Resource was launched. ${ }^{573}$ This is designed to assist organisations holding personal data with a simple basis to conduct a self-assessment of their compliance under Irish Data Protection Law. In April, the Irish Data Protection Commissioner also issued guidance on how organisations should deal with the loss of personal data.

In a number of Member States, there is uncertainty as to the applicability of general rules pertaining to data protection to video monitoring, particularly when the visual data collected are not kept. In Spain, the Agencia Española de Protección de Datos [Spanish Data Protection Agency] has set up a practical Guide on recommendations on video surveillance, since the number of queries presented by the citizens on video surveillance has significantly increased in the

http://www.bundesverfassungsgericht.de/entscheidungen/rk20090522_2bvr028709.html (22.10.2009).

570 http://www.regeringen.se/sb/d/8670/a/78367 (The government bill En anpassad försvarsunderrättelseverksamhet, 2006/07:63 - An Adapted Military Intelligence) (10.05.2009).

$571 \mathrm{http} / / /$ www.sweden.gov.se/sb/d/11977/a/126990\#126990 (13.10.2009).

572 http://www.cantinhodoemprego.com/index.php/uteis/outros/583-dispositivo-electronico-dematricula-em-todos-os-veiculos-automoveis-chip.html (15.12.2009).

573 Ireland/The Office of the Data Protection Commissioner (2009) The Data Protection Audit Resource, available at: www.dataprotection.ie/documents/enforcement/AuditResource.pdf (26.09.2009) 
last years and that in 2008 the Agency had performed more than 365 inspections on this topic. ${ }^{574}$

In May 2009, the Commission adopted a Recommendation on the implementation of privacy and data protection principles in applications supported by radio-frequency identification ${ }^{575}$. The Recommendation calls on Member States to ensure that a framework for privacy and data protection impact assessments is developed by industry and submitted to the Article 29 Working Party for endorsement. It also calls for measures to provide information and transparency on RFID applications and sets out principles for the use of RFID in retail environments.

574 https://www.agpd.es/portalweb/canaldocumentacion/publicaciones/common/pdfs/ guia videovigilancia.pdf $(01.10 .2009)$.

575 http://ec.europa.eu/information_society/policy/rfid/documents/ recommendationonrfid2009.pdf 


\section{Conclusions}

\section{The Racial Equality Directive}

The year 2010 marks 10 years since the Racial Equality Directive was adopted. It is therefore timely to consider how the information collected for this year's FRA Annual Report throws light on the workings of the Directive and its general impact.

On the positive side, Member States which before 2000 had no legislation for combating racial discrimination or no organisation offering victim support, now have both, and in some of these countries cases of discrimination have been prosecuted by legal authorities for the first time. The 2009 Eurobarometer shows that in some Member States there has been an increase in their citizens' knowledge of their rights relating to discrimination or harassment. The FRA own research in 2009 on social partners and the Racial Equality Directive found many respondents who saw the directive as helping them significantly to get ethnic equality on the agenda at their place of work.

Nevertheless, the facts and figures provided by the FRA information-gathering networks during 2009 continue to suggest weaknesses in the application of the directive. Some Member States have been slow to pass national legislation to comply with the directive, and many had to be notified by the Commission that their transposition was unsatisfactory in some way. Although the directive requires all Member States to designate an equality body to provide independent assistance to victims of discrimination, by the end of 2009 one Member State's equality body was still not active, several others had only very recently become operational and had thus no time to become effective, and many Member State's equality bodies were categorised as under-resourced or lacking in adequate powers.

This may be part of the explanation why in 2009 , as in other years, the numbers of official complaints of discrimination have been rather low. The FRA 2009 EU-MIDIS study showed that majority of victims did not report the incident to an equality body, often because they thought that little would happen if they did. Another EU-MIDIS finding is that most victims were unaware of the existence of equality bodies to complain to.

In the FRA's 2009 interview survey of representatives of employers and trade unions about their perceptions and experiences of the Racial Equality Directive, it was noticeable that some respondents exhibited a low awareness of the equality bodies and their roles, and had no contact with them. The same report also found that some employers and trade union representatives believed that racial discrimination was a non-issue in their country, and deserved no special attention. Interestingly, a similar phenomenon was noted in another FRA study 
carried out in 2009 on racism in sport. ${ }^{576}$ Interviews with representatives of sport federations, athletes' organisations and NGOs found that in some Member States they denied the existence of the problem of racism, and failed to see that any action might need to be taken. (Only 10 Member States had reasonably good monitoring systems regarding racist incidents in sport, and six had no data at all.) These findings of these two studies are in contrast with the EU-MIDIS data which showed that in all Member States the majority of interviewees in all minority and migrants groups felt that they routinely experienced racial discrimination.

- On the basis of the low numbers of complaints identified in 2009, and of the findings of EU-MIDIS survey, the 2009 special Eurobarometer, and the interviews with social partners and sports representatives, it is clear that the promotional role of the Directive, ${ }^{577}$ as well as the general capacity and effectiveness of equality bodies, needs to be given much more weight by the Member States. Clearly the awareness raising function of the Racial Equality Directive is deficient, and more attention needs to be paid to this area.

\section{Racist crime}

Racist violence and crime continues to be a problem in Member States. As in other years, the quality of data collected on racist crime in the EU during 2009 shows a significant variation between Member States. This means that comparisons of figures between Member States are relatively meaningless. However, comparisons of trends over time within Member States are more useful and demonstrate the existence of a continuing and often increasing problem. For example, only six Member States collect sufficiently robust criminal justice data to allow a comparison of trends in anti-Semitic crime, and these statistics show that between 2001 and 2008 five of them experienced an overall upward trend, and that between 2007-2008 two countries showed an upward trend and four a downward one. One important conclusion from the EU-MIDIS survey is the fact that racist attacks should not be simply assumed to be a problem of right-wing and extremist perpetrators, but are more of 'everyday' crimes committed by 'ordinary' perpetrators, such as people from the local neighbourhood. Of particular concern from the study is the finding that a significant minority of perpetrators were identified as police or other public officials.

The need for Member States to have implemented by the end of 2010 the Council Framework Decision ${ }^{578}$ on combating certain forms of racism and xenophobia by criminal law is likely to bring some improvement in data collection on racist crime. As this process of improvement continues, this is likely initially to result in an increase in recorded incidents. Therefore, during this period an increase in recorded incidents of racist crime is likely to be more

\footnotetext{
576 Racism and Ethnic Discrimination in Sport in the EU FRA, Vienna 2010

577 Article 10 of the Directive.

578 2008/913/JHA
} 
a reflection of a better data gathering system than of a genuine increase in the problem. This phenomenon is parallel to that described in Chapter 1 on discrimination complaints to equality bodies, where EU legislation has begun to encourage Member States to institute better recording and response systems to discrimination complaints, so that initial increases in complaints may be just as likely to reflect that the new system is working better, rather than demonstrating an increasing problem.

- Following improvements in data collection systems, the statistics on racist crime are likely to become more meaningful over time. Meanwhile, in 2010, with a view to the forthcoming implementation of Framework Decision 2008/913/JHA, the Agency is undertaking a thorough mapping of existing criminal justice and civil society data collection on racist crime and other hate crimes in the EU. The results will highlight gaps in data and indicate those areas where Member States should be encouraged to take action to improve their systems.

\section{Discriminatory legislation}

A recurring theme in FRA Annual Reports has been the issue of discriminatory legislation (sometimes known as 'legal discrimination') referring to laws which can be seen to be discriminatory in their effect against non-nationals. This year, as in other years, cases were found where legal and administrative barriers restrict the access of (legally resident) non-nationals to employment opportunities, usually for jobs in the public sector. For example, in some countries long-term legally-resident nurses have been excluded from employment or promotion opportunities in the healthcare sector because they did not possess the citizenship of an EU country. Many other examples can be found in the FRA's 2010 comparative report on racial discrimination in employment. ${ }^{579}$ Nevertheless, as shown in Section 4.2.6, there were during 2009 several examples of legal rulings against discrimination on grounds of nationality, some at national level, and one by the ECtHR.

While the Equality Directives do not cover differences of treatment which arise from the legal status of third country nationals, it is clear that discrimination on grounds of nationality is a practice which is becoming increasingly questioned, and not only because differential treatment on the grounds of nationality may constitute in some circumstances indirect discrimination on grounds of race, ethnic origin or religion. There have been developments which aim to reduce restrictions on grounds of nationality, such as the Council Directive 2003/109/EC on the status of third-country nationals who are long-term residents. Since its entry into force, third country nationals who are long-term residents should be entitled to access to public employment on equal standing with EU citizens. ${ }^{580}$ However, as the FRA Annual Report in 2007 showed, even

\footnotetext{
579 Migrants, Minorities and Employment: Exclusion and discrimination in the 27 Member States of the European Union FRA, Vienna 2010

580 Official Journal of the European Union, Directive 2003/109/EC, Article 11
} 
within one country there can be contradictory court rulings regarding the kinds of jobs to which access can be justifiably restricted. ${ }^{581}$

A 2009 EU report comparing legal instruments in this area concludes that "differences of treatment on grounds of nationality are increasingly regarded as suspect in international human rights law" with the implication that the situation of third-country nationals who are legally residing in EU Member States may have to be more closely aligned with that of the nationals of other EU Member States. ${ }^{582}$ Furthermore, as the 2010 FRA comparative report on racial discrimination in employment concluded, from the perspective of social cohesion, it is desirable for the society as a whole that the largest possible part of the resident population enjoys a secure legal status and is granted access to basic rights and resources. ${ }^{583}$

- Member States should not establish or maintain differences in treatment between third country nationals and nationals of other EU Member States with regard to access to opportunities in public sector employment unless such differences can be justified as legitimate in the pursuit of legitimate objectives and is seen to be reasonable and proportionate to such objectives.

\section{Extreme exploitation}

Immigration laws construct a legal hierarchy between citizens and non-citizens, and differentiate the latter into many diverse status categories that are each entitled to different rights. ${ }^{584}$ Persons with an insecure status are more vulnerable to discrimination and exploitation in employment and other areas of socioeconomic life. ${ }^{585}$ This year's Annual Report describes many examples of extreme exploitation of migrant workers reported during the year, often made possible by their legal vulnerability, working in violation of labour regulations, paid less than collective agreements, working extremely long hours in unhealthy conditions, and denied sickness leave. The worst conditions of all are experienced by irregular workers. As stated in Section 6.1.1, whilst the Employers Sanctions Directive of 2009 may not be a very satisfactory safeguard against the exploitation of irregular workers, there have been some positive developments against these kinds of labour market abuses in several Member States.

The concentration of migrant workers in exploitative working conditions and squalid living conditions can be both a consequence of and a stimulus to racist attitudes. In early 2010 in Italy, dozens of mainly African migrant farm workers

581 FRA, Annual Report 2007, Vienna, p. 63/f

582 Links between Migration and Discrimination, European Network of Legal Experts in the nondiscrimination field/Olivier de Schutter European Commission, Luxembourg 2009, p.6

583 FRA, Migrants, minorities and employment - Exclusion and discrimination in the 27 Member States of the European Union Vienna, 2010, Section 5.1

584 FRA, Migrants, minorities and employment - Exclusion and discrimination in the 27 Member States of the European Union Vienna, 2010

585 FRA, Annual Report 2005, Vienna, p. 35 
were involved in protest riots and in clashes with the police and local residents in Rosarno, in the southern region of Calabria, following attacks by white youths with air rifles. Property was damaged and dozens of people injured. ${ }^{586}$ This has echoes of the Spanish riots in 2000 in El Ejido, a small Andalusian town, which was racked by three days of arson and violence against (often irregular) immigrant agricultural workers, living and working locally in appalling conditions.

The FRA is engaged in or planning research on several aspects of irregular migrants. One will be a large scale project on the fundamental rights situation of irregular migrants in the EU, and another will be a study of the access to healthcare by irregular migrants, conducted in $10 \mathrm{EU}$ Member States.

- Member States should make full use of the possibilities offered by the Employers Sanctions Directive, which obliges Member States to define the conditions under which they may grant temporary residence permits in a similar way as to that already done for victims of trafficking under Directive 2004/81. ${ }^{587}$ Member States should set up effective complaint mechanisms by which third-country nationals could lodge complaints directly or through designated third parties such as trade unions or other associations.

\section{Asylum, immigration and integration of migrants}

In the areas of asylum, immigration and integration, this year's report has highlighted several issues of concern during 2009. With regard to developments relating to pre-removal detention, described in section 6.1 of this report, it should be noted that Member States have the obligation to complete the transposition process of the Return Directive during 2010. If implemented in a manner which fully respects fundamental rights, the Return Directive could act as a useful instrument to tackle some of the existing concerns over the standard of treatment of third country nationals in return proceedings.

In the area of pre-removal detention, there are alternatives to detention which constitute important ways to reduce the need to resort to deprivation of liberty. These include a variety of measures, such as the duty to surrender passport and travel documents, residence restrictions or reporting requirements. Compared to the deprivation of liberty, these alternatives are less intrusive.

- Bearing in mind the principle of proportionality, and on the assumption that deprivation of liberty should be a measure of last resort, the Agency encourages Member States to set out in national legislation clear rules dealing with alternatives to detention, including procedures to ensure that the

\footnotetext{
586 http://news.bbc.co.uk/2/hi/8447990.stm

587 The indicated criminal offences constituting the bases for granting residence are related specifically to situations where employees are mostly exposed to exploitation (Art. 9 (1)(c) particularly exploitative working conditions; Art. 9 (1)(e) - employment of a minor), while remaining infringements listed under Art. 9 are penalised for other reasons.
} 
option of detention is resorted to only if the application of less coercive measures would not be sufficient.

\section{Vulnerability of children and the need to involve them}

The year 2009 marked the 20th anniversary of the adoption of the UN Convention on the Rights of the Child. In accordance with the Convention, a child is anyone below the age of eighteen years (unless under the law applicable to the child, majority is attained earlier). Yet, in spite of the right of every child to be heard, which the Committee on the Rights of the Child has authoritatively interpreted this year, children have mostly been treated as 'objects' of 'adult' decision-making. Their views have often not been taken into account or even listened to, and their best interests often not been considered. As research carried out by the FRA has shown, large gaps exist not just regarding the ability of the legal and social systems of EU Member States to take the views of children on board, but also to provide for basic material and legal support and conditions which would allow for their interests to be known and protected. The provision of appropriate complements to the limited legal capacity of the child, or appropriate legal advice regarding the protection of the children's basic interests, for instance, have often been absent, preventing children from receiving the basic protection that they need. The initiative to establish a communications procedure under the UN Convention on the Rights of the Child can serve to highlight the difficulties which children face in seeing their rights protected.

Also important for ensuring protection has been the increasing emphasis placed on the prevention of offences, an approach followed by the Commission Proposal for a Council Framework Decision on combating the sexual abuse and sexual exploitation of children, and child pornography, for instance. However, the search for an appropriate balance among various aspects of human rights protection involved, upholding the rights of adults, while having special regard for the particular vulnerabilities of children regarding basic right enjoyment, remains a challenge, for a majority of EU policies. The statement in the Stockholm Programme that the rights of the child concern all EU policies and must be systematically and strategically taken into account with a view to ensuring an integrated approach sets out one of the major challenges for EU policy action in the years ahead. Undoubtedly, this challenge is increased by the need to ensure that children's views on their protection needs are adequately reflected and taken into consideration when protection systems are developed and implemented.

The importance of child participation should also be highlighted when considering 'care' for children. Social institutions should not just serve for the 'placement' of children, but for ensuring their views are known and their participation. The importance of residential care of children outside traditional 'institutional care', and the case for the transition from 'institutional' to 
'community-based' care has been forcefully put forward by the Report of Ad Hoc Expert Group on this topic mentioned in this report.

- It is therefore to be hoped that institutional development, both at the level of the EU and the Member States, moves in the direction of the creation of 'child specific' frameworks, allowing for child participation, and that national human rights institutions, equality bodies and ombudspersons, increase their child protection focus rather than see it diminished. Residential care of children should move away from isolation and de-personalisation in large 'care institutions' to become more personalised and community-based.

\section{Information society, respect for private life and protection of personal data}

Rapid technological development and extensive exchange of personal data have given rise to many initiatives at the regional as well as international level. The main aim of such initiatives is to reconsider the current legal framework on data protection and strengthen the protection of the individual's privacy. The EU has played an important role in driving the development and introduction of national data protection law in a number of legal systems in the EU. The Stockholm Programme newly reaffirms the Union's commitment to data protection. Ms Viviane Reding, Vice-President of the European Commission, emphasised in her speech on 28 January 2010, on the occasion of Data Protection Day, the paramount importance of data protection to the EU. Commissioner Reding called for the assurance that personal data are protected against any unauthorised use, and that citizens have the right to decide on the way their data are processed.

There have been significant developments concerning the Data Retention Directive aimed at the retention of communication data for the purpose of the investigation, detection and prosecution of serious crimes. At the EU level, the European Court of Justice upheld the appropriateness of the legal basis on which the directive had been adopted in 2006. Furthermore, the Commission launched infringement proceedings against several Member States and obtained favourable judgments from the ECJ against them. At the Member States' level, the constitutional courts of Romania and Germany declared their national laws implementing the Data Retention Directive to be unconstitutional.

- The FRA's 2010 Legal Study on Assessment of Data Protection Measures and Relevant Institutions analyses the Data Protection Directive. This comparative analysis has identified challenges and formulated opinions based on the findings. The lack of independence of several Data Protection Authorities, as well as a lack of adequate financial resources, understaffing, and lack of enforcement of the data protection system, constitute major challenges faced by the authorities. For the FRA, guarantees for effective enforcement of data protection are crucial to achieve deterrence and to prevent data protection violations. Dedicating more emphasis to enforcement 
would also help to convince the population that data protection issues are taken seriously. Based on the outcome of this report, in the context of the increasing significance of data protection in today's fast developing digital era, the FRA will continue its work in the field of data protection in the future.

\section{Sexual orientation discrimination}

Last year's Annual Report described the two major reports published by the FRA in 2009 on discrimination on grounds of sexual orientation, highlighting, amongst other things, the inadequacies and inconsistencies in legislation to protect LGBT people from discrimination, and the ways that such discrimination has an impact on their lives. Most of the issues are still relevant, as this year's Annual Report can report both positive and negative developments in the EU and in various Member States.

The number of EU Member States that ban sexual orientation discrimination beyond employment, wholly or partially covering the areas foreseen by the Racial Equality Directive, has continued to rise, as well as the number of equality bodies which include it in their remit. However, the hierarchy of discrimination grounds in EU law has not been removed and there appear to be difficulties with the adoption of a directive that would remedy this situation and treat all grounds of discrimination equally, as the Charter of Fundamental Rights does. The evolving situation at the national level makes any delay in the adoption of the proposal for a 'horizontal' directive particularly untenable.

- The FRA reiterates its plea for an equal right to equal treatment and, thus, its support for a horizontal directive for all discrimination grounds covered by Article 19 of the Treaty on the Functioning of the EU.

\section{Same sex partners}

In Sweden, Austria and Slovenia there were government actions or legal rulings in 2009 that strengthened the rights of same-sex civil partners. In Lithuania, Italy or Romania, on the other hand, there were actions or rulings in the other direction. Such developments can have implications for the enjoyment of rights to free movement for spouses and partners, and illustrate the difficulties faced by same-sex partners in being treated as family members under current law and practice at both Member State and EU level.

- The FRA calls upon the EU and Member States to embrace within the definition of 'family member' the same-sex partner, whether married, registered, or in a de facto union. This is especially important in the context of free movement of EU citizens and family reunification of third country nationals, an area where intersectional discrimination is left unaddressed. 


\section{Homophobic discourse and hate crime}

In 2009 there have been attempts to substantially restrict the possibility of expressing and disseminating information on homosexuality, as in the case of Lithuania. Criminalising the dissemination of information on homosexuality and LGBT issues would prevent the occurrence of any public message or event, causing undue restriction of the rights to equal treatment and freedom of expression.

Furthermore, varying approaches to hate crime and hate speech still exist, with only little progress in this field. Some initiatives at the local level address the concern from a pragmatic point of view, but there still is a worrying conceptualisation regarding the criminalisation of homophobic incidents, which sees, for example, the introduction of 'aggravating circumstances' for crimes motivated by hate against LGBT people as conveying privileged rights for a certain population.

- Many LGBT persons adopt a strategy of invisibility due to the fear of homophobia, transphobia and discrimination. They tend to adjust to the heteronormativity of public spaces as a 'survival strategy' because of the perceived risks of being exposed to hate speech or violence. In order to counter 'invisibility' of the LGBT population, effective and harmonised measures to counter homophobic speech and violence should be developed, alongside tools for facilitating the reporting and recording of incidents.

\section{Transgender discrimination}

As regards the position of transgender people, the situation of legal uncertainty in national legal systems remains, with full implementation of current EU equal treatment legislation still dubious for this population. Transgender people are subject to high societal stigma and marginalisation, as well as exclusion from the labour market. The position of transgender people remains critical in all those Member States that still do not legally recognise the new identity of transgender and transsexual people.

- The proper implementation of the Gender Recast Directive should be closely monitored to ensure that Member States effectively address discrimination against transgender people. The inclusion of gender identity among the prohibited grounds of discrimination in the Goods and Services Directive would be a welcome development in the effort to clarify existing definitions.

\section{Disability}

There are several references in the Annual Report to the rights for persons with disabilities, including positive action to promote participation of disabled persons in public life, capacity building for organisations active in the field and finally the activities related to the implementation of the UN Convention on the 
Rights of Persons with Disabilities (UN CRPD). Coming to force of the UN CRPD in 2008 paved a way forward for protection, promotion and monitoring of rights of persons with disabilities. On 26 November 2009, the Council of the European Union decided ${ }^{588}$ to approve, "as soon as possible" the CRPD so that the EU becomes a party to the CRPD

The Convention establishes disability not as a welfare matter, but as a human rights issue and a matter of law. In the letter of the Convention persons with disabilities are perceived not as passive recipients of social policy, but as rights holders actively exercising their rights and deciding what is best for them. Consequently, one of the Convention's core messages is that persons with disabilities are not objects, but subjects and should be treated with respect and dignity.

The Convention reflects a disability strategy which combines antidiscrimination, equal opportunities and active inclusion measures. It also identifies areas where adaptations have to be made so that persons with disabilities can exercise their rights, and areas where the protection of their rights must be reinforced because of their routine violation. One of the key underlying messages of the Convention is the presumption of a capacity for self-determination and the associated right to independent living.

- In the spirit of the Convention, the core of FRA's disability project in 2010 will focus on what enables persons with intellectual disabilities and mental health problems to live independently.

588 See http://eur-lex.europa.eu/LexUriServ/LexUriServ.do?uri=OJ:L:2010:023:0035:0061:EN:PDF 


\section{Annex 1: International human rights instruments}

Figure A1: Acceptance of selected international human rights instruments in the EU27, by country

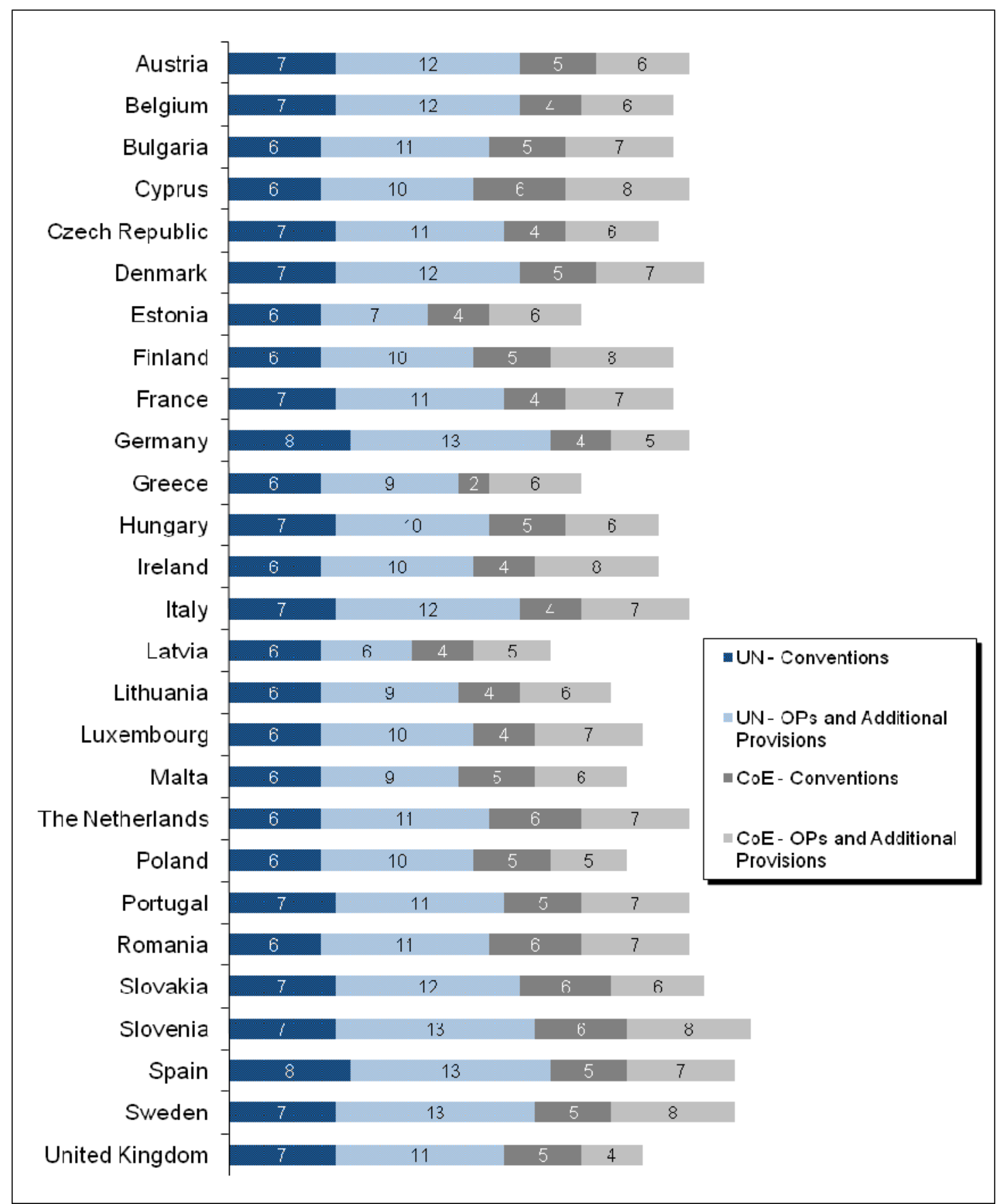

Overview of the level of formal commitment (state parties to and acceptance of various optional provisions in conventions, such as individual and state complaints, and inquiry procedures) of the EU Member States to nine selected conventions of the United Nations ${ }^{589}$ and to four conventions of the Council of Europe. ${ }^{590}$

589 International Convention on the Elimination of All Forms of Racial Discrimination (ICERD), International Covenant on Civil and Political Rights (ICCPR), International Covenant on Economic, Social and Cultural Rights 
(ICESCR), Convention on the Elimination of All Forms of Discrimination against Women (CEDAW), Convention against Torture and Other Cruel, Inhuman or Degrading Treatment or Punishment (CAT), Convention on the Rights of the Child (CRC), International Convention on the Protection of the Rights of All Migrant Workers (ICRMW), International Convention for the Protection of All Persons from Enforced Disappearance (ICPED), Convention on the Rights of Persons with Disabilities (ICRPD).

590 The Convention for the Protection of Human Rights and Fundamental Freedoms (ECHR), including its 8 optional protocols, the European Social Charter (ESC), the Framework Convention for the Protection of National Minorities (FCNM), the European Charter for Regional and Minority Languages (CRML), the European Convention for the Prevention of Torture and Inhuman or Degrading Treatment or Punishment (ECPT), and the Convention on Action against Trafficking in Human Beings (CATHB). 


\section{Overview of the level of formal commitment of EU Member States to UN and Council of Europe Conventions}

Table A1: Overview of the level of formal commitment of the EU Member States to nine selected United Nations conventions, by country*

\begin{tabular}{|c|c|c|c|c|c|c|c|c|c|c|c|c|c|c|c|c|c|c|c|c|c|c|c|c|c|c|c|}
\hline Country & AT & BE & BG & CY & $\mathrm{CZ}$ & DK & EE & $\mathrm{FI}$ & FR & DE & EL & HU & IE & IT & LV & LT & LU & MT & NL & PL & PT & RO & SK & SI & ES & SE & UK \\
\hline Total accepted & 19 & 19 & 17 & 16 & 18 & 19 & 13 & 16 & 18 & 21 & 15 & 17 & 16 & 19 & 12 & 15 & 16 & 15 & 17 & 16 & 18 & 17 & 17 & 20 & 21 & 20 & 18 \\
\hline ICERD & $\checkmark$ & $\checkmark$ & $\checkmark$ & $\checkmark$ & $\checkmark$ & $\checkmark$ & $\checkmark$ & $\checkmark$ & $\checkmark$ & $\checkmark$ & $\checkmark$ & $\checkmark$ & $\checkmark$ & $\checkmark$ & $\checkmark$ & $\checkmark$ & $\checkmark$ & $\checkmark$ & $\checkmark$ & $\checkmark$ & $\checkmark$ & $\checkmark$ & $\checkmark$ & $\checkmark$ & $\checkmark$ & $\checkmark$ & $\checkmark$ \\
\hline ICERD - Individual complaints & $\checkmark$ & $\checkmark$ & $\checkmark$ & $\checkmark$ & $\checkmark$ & $\checkmark$ & $\mathbf{x}$ & $\checkmark$ & $\checkmark$ & $\checkmark$ & $\mathbf{x}$ & $\checkmark$ & $\checkmark$ & $\checkmark$ & $\mathbf{x}$ & $\mathbf{x}$ & $\checkmark$ & $\checkmark$ & $\checkmark$ & $\checkmark$ & $\checkmark$ & $\checkmark$ & $\checkmark$ & $\checkmark$ & $\checkmark$ & $\checkmark$ & $\mathbf{x}$ \\
\hline ICCPR & $\checkmark$ & $\checkmark$ & $\checkmark$ & $\checkmark$ & $\checkmark$ & $\checkmark$ & $\checkmark$ & $\checkmark$ & $\checkmark$ & $\checkmark$ & $\checkmark$ & $\checkmark$ & $\checkmark$ & $\checkmark$ & $\checkmark$ & $\checkmark$ & $\checkmark$ & $\checkmark$ & $\checkmark$ & $\checkmark$ & $\checkmark$ & $\checkmark$ & $\checkmark$ & $\checkmark$ & $\checkmark$ & $\checkmark$ & $\checkmark$ \\
\hline ICCPR - State complaints & $\checkmark$ & $\checkmark$ & $\checkmark$ & $x$ & $\checkmark$ & $\checkmark$ & $x$ & $\checkmark$ & $x$ & $\checkmark$ & $\mathrm{x}$ & $\checkmark$ & $\checkmark$ & $\checkmark$ & $x$ & $x$ & $\checkmark$ & $\checkmark$ & $\checkmark$ & $\checkmark$ & $x$ & $x$ & $\checkmark$ & $\checkmark$ & $\checkmark$ & $\checkmark$ & $\checkmark$ \\
\hline ICCPR - OP1 (individual complaints) & $\checkmark$ & $\checkmark$ & $\checkmark$ & $\checkmark$ & $\checkmark$ & $\checkmark$ & $\checkmark$ & $\checkmark$ & $\checkmark$ & $\checkmark$ & $\checkmark$ & $\checkmark$ & $\checkmark$ & $\checkmark$ & $\checkmark$ & $\checkmark$ & $\checkmark$ & $\checkmark$ & $\checkmark$ & $\checkmark$ & $\checkmark$ & $\checkmark$ & $\checkmark$ & $\checkmark$ & $\checkmark$ & $\checkmark$ & $\mathbf{x}$ \\
\hline ICCPR - OP2 (death penalty) & $\checkmark$ & $\checkmark$ & $\checkmark$ & $\checkmark$ & $\checkmark$ & $\checkmark$ & $\checkmark$ & $\checkmark$ & $\checkmark$ & $\checkmark$ & $\checkmark$ & $\checkmark$ & $\checkmark$ & $\checkmark$ & $x$ & $\checkmark$ & $\checkmark$ & $\checkmark$ & $\checkmark$ & $\mathrm{s}$ & $\checkmark$ & $\checkmark$ & $\checkmark$ & $\checkmark$ & $\checkmark$ & $\checkmark$ & $\checkmark$ \\
\hline ICESCR & $\checkmark$ & $\checkmark$ & $\checkmark$ & $\checkmark$ & $\checkmark$ & $\checkmark$ & $\checkmark$ & $\checkmark$ & $\checkmark$ & $\checkmark$ & $\checkmark$ & $\checkmark$ & $\checkmark$ & $\checkmark$ & $\checkmark$ & $\checkmark$ & $\checkmark$ & $\checkmark$ & $\checkmark$ & $\checkmark$ & $\checkmark$ & $\checkmark$ & $\checkmark$ & $\checkmark$ & $\checkmark$ & $\checkmark$ & $\checkmark$ \\
\hline ICESCR - OP & $x$ & $\mathrm{~s}$ & $x$ & $x$ & $x$ & $x$ & $\mathrm{x}$ & $\mathrm{s}$ & $x$ & $x$ & $\mathrm{x}$ & $x$ & $x$ & $\mathrm{~s}$ & $x$ & $x$ & $\mathrm{~s}$ & $x$ & $\mathrm{~s}$ & $\mathrm{x}$ & $\mathrm{s}$ & $x$ & $\mathrm{~s}$ & $\mathrm{~s}$ & s & $x$ & $x$ \\
\hline CEDAW & $\checkmark$ & $\checkmark$ & $\checkmark$ & $\checkmark$ & $\checkmark$ & $\checkmark$ & $\checkmark$ & $\checkmark$ & $\checkmark$ & $\checkmark$ & $\checkmark$ & $\checkmark$ & $\checkmark$ & $\checkmark$ & $\checkmark$ & $\checkmark$ & $\checkmark$ & $\checkmark$ & $\checkmark$ & $\checkmark$ & $\checkmark$ & $\checkmark$ & $\checkmark$ & $\checkmark$ & $\checkmark$ & $\checkmark$ & $\checkmark$ \\
\hline CEDAW - OP & $\checkmark$ & $\checkmark$ & $\checkmark$ & $\checkmark$ & $\checkmark$ & $\checkmark$ & $x$ & $\checkmark$ & $\checkmark$ & $\checkmark$ & $\checkmark$ & $\checkmark$ & $\checkmark$ & $\checkmark$ & $x$ & $\checkmark$ & $\checkmark$ & $x$ & $\checkmark$ & $\checkmark$ & $\checkmark$ & $\checkmark$ & $\checkmark$ & $\checkmark$ & $\checkmark$ & $\checkmark$ & $\checkmark$ \\
\hline CEDAW - Inquiry procedure & $\checkmark$ & $\checkmark$ & $\checkmark$ & $\checkmark$ & $\checkmark$ & $\checkmark$ & $x$ & $\checkmark$ & $\checkmark$ & $\checkmark$ & $\checkmark$ & $\checkmark$ & $\checkmark$ & $\checkmark$ & $x$ & $\checkmark$ & $\checkmark$ & $x$ & $\checkmark$ & $\checkmark$ & $\checkmark$ & $\checkmark$ & $\checkmark$ & $\checkmark$ & $\checkmark$ & $\checkmark$ & $\checkmark$ \\
\hline CAT & $\checkmark$ & $\checkmark$ & $\checkmark$ & $\checkmark$ & $\checkmark$ & $\checkmark$ & $\checkmark$ & $\checkmark$ & $\checkmark$ & $\checkmark$ & $\checkmark$ & $\checkmark$ & $\checkmark$ & $\checkmark$ & $\checkmark$ & $\checkmark$ & $\checkmark$ & $\checkmark$ & $\checkmark$ & $\checkmark$ & $\checkmark$ & $\checkmark$ & $\checkmark$ & $\checkmark$ & $\checkmark$ & $\checkmark$ & $\checkmark$ \\
\hline CAT - OP & $\mathrm{s}$ & s & $x$ & $\checkmark$ & $\checkmark$ & $\checkmark$ & $\checkmark$ & $\mathrm{s}$ & $\checkmark$ & $\checkmark$ & $x$ & $x$ & $\mathrm{~s}$ & $\mathrm{~s}$ & $x$ & $x$ & $\mathrm{~s}$ & $\checkmark$ & $\mathrm{s}$ & $\checkmark$ & $\mathrm{s}$ & $\checkmark$ & $x$ & $\checkmark$ & $\checkmark$ & $\checkmark$ & $\checkmark$ \\
\hline CAT - State complaints & $\checkmark$ & $\checkmark$ & $\checkmark$ & $\checkmark$ & $\checkmark$ & $\checkmark$ & $\checkmark$ & $\checkmark$ & $\checkmark$ & $\checkmark$ & $\checkmark$ & $\checkmark$ & $\checkmark$ & $\checkmark$ & $\checkmark$ & $\checkmark$ & $\checkmark$ & $\checkmark$ & $\checkmark$ & $\checkmark$ & $\checkmark$ & $\checkmark$ & $\checkmark$ & $\checkmark$ & $\checkmark$ & $\checkmark$ & $\checkmark$ \\
\hline CAT - Individual complaints & $\checkmark$ & $\checkmark$ & $\checkmark$ & $\checkmark$ & $\checkmark$ & $\checkmark$ & $\checkmark$ & $\checkmark$ & $\checkmark$ & $\checkmark$ & $\checkmark$ & $\checkmark$ & $\checkmark$ & $\checkmark$ & $\checkmark$ & $\checkmark$ & $\checkmark$ & $\checkmark$ & $\checkmark$ & $\checkmark$ & $\checkmark$ & $\checkmark$ & $\checkmark$ & $\checkmark$ & $\checkmark$ & $\checkmark$ & $\checkmark$ \\
\hline CAT - Inquiry procedure & $\checkmark$ & $\checkmark$ & $\checkmark$ & $\checkmark$ & $\checkmark$ & $\checkmark$ & $\checkmark$ & $\checkmark$ & $\checkmark$ & $\checkmark$ & $\checkmark$ & $\checkmark$ & $\checkmark$ & $\checkmark$ & $\checkmark$ & $\checkmark$ & $\checkmark$ & $\checkmark$ & $\checkmark$ & $x$ & $\checkmark$ & $\checkmark$ & $\checkmark$ & $\checkmark$ & $\checkmark$ & $\checkmark$ & $\checkmark$ \\
\hline CRC & $\checkmark$ & $\checkmark$ & $\checkmark$ & $\checkmark$ & $\checkmark$ & $\checkmark$ & $\checkmark$ & $\checkmark$ & $\checkmark$ & $\checkmark$ & $\checkmark$ & $\checkmark$ & $\checkmark$ & $\checkmark$ & $\checkmark$ & $\checkmark$ & $\checkmark$ & $\checkmark$ & $\checkmark$ & $\checkmark$ & $\checkmark$ & $\checkmark$ & $\checkmark$ & $\checkmark$ & $\checkmark$ & $\checkmark$ & $\checkmark$ \\
\hline CRC - OP1 (armed conflict) & $\checkmark$ & $\checkmark$ & $\checkmark$ & $\mathrm{s}$ & $\checkmark$ & $\checkmark$ & $\mathrm{s}$ & $\checkmark$ & $\checkmark$ & $\checkmark$ & $\checkmark$ & $\mathrm{s}$ & $\checkmark$ & $\checkmark$ & $\checkmark$ & $\checkmark$ & $\checkmark$ & $\checkmark$ & $\checkmark$ & $\checkmark$ & $\checkmark$ & $\checkmark$ & $\checkmark$ & $\checkmark$ & $\checkmark$ & $\checkmark$ & $\checkmark$ \\
\hline
\end{tabular}




\begin{tabular}{|c|c|c|c|c|c|c|c|c|c|c|c|c|c|c|c|c|c|c|c|c|c|c|c|c|c|c|c|}
\hline Country & AT & BE & BG & CY & CZ & DK & $\mathrm{EE}$ & FI & FR & DE & EL & HU & $\mathbf{I E}$ & IT & LV & LT & LU & MT & NL & PL & PT & Ro & SK & SI & ES & SE & UK \\
\hline CRC - OP2 (prostitution) & 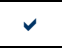 & $\checkmark$ & 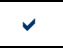 & 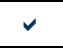 & $\mathrm{s}$ & $r$ & 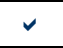 & $\mathrm{s}$ & $\checkmark$ & 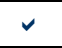 & 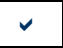 & $\mathrm{s}$ & $\mathrm{s}$ & $\checkmark$ & 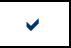 & $\checkmark$ & $\mathrm{s}$ & $\mathrm{s}$ & 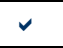 & $\checkmark$ & 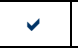 & 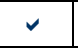 & 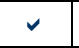 & $\checkmark$ & $\checkmark$ & r & $\checkmark$ \\
\hline ICRMW & $\mathrm{x}$ & $x$ & $x$ & $\mathrm{x}$ & $x$ & $\mathrm{x}$ & $\mathrm{x}$ & $x$ & $\mathrm{x}$ & $\mathrm{x}$ & $x$ & $x$ & $x$ & $\mathrm{x}$ & $x$ & $x$ & $x$ & $x$ & $\mathrm{x}$ & $\mathrm{x}$ & $x$ & $x$ & $x$ & $x$ & $\mathrm{x}$ & $x$ & $x$ \\
\hline ICPED & $\mathrm{s}$ & $\mathrm{s}$ & $\mathrm{s}$ & $\mathrm{s}$ & $x$ & $\mathrm{~s}$ & $x$ & s & $\checkmark$ & $\checkmark$ & $\mathrm{s}$ & $x$ & $\mathrm{~s}$ & $\mathrm{~s}$ & $x$ & s & $\mathrm{s}$ & $\mathrm{s}$ & s & $x$ & s & s & s & $\mathrm{s}$ & $\checkmark$ & $\mathrm{s}$ & $x$ \\
\hline CRPD & $\checkmark$ & $\checkmark$ & $\mathrm{s}$ & $\mathrm{s}$ & $\checkmark$ & $\checkmark$ & $\mathrm{s}$ & s & $\mathrm{s}$ & $\checkmark$ & $\mathrm{s}$ & $\checkmark$ & $\mathrm{s}$ & $\checkmark$ & $\mathrm{s}$ & $\mathrm{s}$ & $\mathrm{s}$ & $\mathrm{s}$ & $\mathrm{s}$ & $\mathrm{s}$ & $\checkmark$ & $\mathrm{s}$ & $\checkmark$ & $\checkmark$ & $\checkmark$ & $\checkmark$ & $\checkmark$ \\
\hline CRPD - OP (individual complaints) & $\checkmark$ & $\checkmark$ & $\mathrm{s}$ & $\mathrm{s}$ & s & $x$ & $x$ & s & $\mathrm{s}$ & $\checkmark$ & $x$ & $\checkmark$ & $x$ & $\checkmark$ & $x$ & s & $\mathrm{s}$ & $\mathrm{s}$ & $x$ & $x$ & $\checkmark$ & s & $\checkmark$ & $\checkmark$ & $\checkmark$ & $\checkmark$ & $\checkmark$ \\
\hline
\end{tabular}

Note: *State parties to and acceptance of various optional provisions in conventions, such as individual and state complaints, and inquiry procedures. ${ }^{59}$

\footnotetext{
${ }^{591}$ See Footnote 1.
} 
Table A2: Overview of the level of formal commitment of the EU Member States to relevant Council of Europe conventions, by country*

\begin{tabular}{|c|c|c|c|c|c|c|c|c|c|c|c|c|c|c|c|c|c|c|c|c|c|c|c|c|c|c|c|}
\hline Country & AT & $\mathrm{BE}$ & BG & CY & CZ & DK & EE & $\mathbf{H}$ & $\mathbf{R}$ & DE & 브 & HU & $\mathbf{E}$ & $\pi$ & LV & LT & LU & MT & $\mathbf{N L}$ & $\mathbf{P L}$ & PT & RO & SK & $\mathbf{S I}$ & ES & SE & UK \\
\hline Total accepted & 9 & 8 & 10 & 12 & 9 & 10 & 9 & 12 & 9 & 8 & 7 & 10 & 11 & 10 & 7 & 9 & 9 & 9 & 11 & 8 & 10 & 11 & 10 & 12 & 10 & 12 & 7 \\
\hline $\mathrm{ECHR}$ & $\checkmark$ & $\checkmark$ & $r$ & $\checkmark$ & $\checkmark$ & $\checkmark$ & $\checkmark$ & $\checkmark$ & $\checkmark$ & $\checkmark$ & $\checkmark$ & $\checkmark$ & $\checkmark$ & $\checkmark$ & $\checkmark$ & $\checkmark$ & $\checkmark$ & $\checkmark$ & $\checkmark$ & $\checkmark$ & $\checkmark$ & $\checkmark$ & $\checkmark$ & $\checkmark$ & $\checkmark$ & $\checkmark$ & $\checkmark$ \\
\hline ECHR P1 (property, education, etc) & $\checkmark$ & $\checkmark$ & $\checkmark$ & $\checkmark$ & $\checkmark$ & $\checkmark$ & $\checkmark$ & $\checkmark$ & $\checkmark$ & $\checkmark$ & $\checkmark$ & $\checkmark$ & $\checkmark$ & $\checkmark$ & $\checkmark$ & $\checkmark$ & $\checkmark$ & $\checkmark$ & $\checkmark$ & $\checkmark$ & $\checkmark$ & $\checkmark$ & $\checkmark$ & $\checkmark$ & $\checkmark$ & $\checkmark$ & $\checkmark$ \\
\hline ECHR P4 (No prison for debt, etc) & $\checkmark$ & $\checkmark$ & $\checkmark$ & $\checkmark$ & $\checkmark$ & $\checkmark$ & $\checkmark$ & $\checkmark$ & $\checkmark$ & $\checkmark$ & $x$ & $\checkmark$ & $\checkmark$ & $\checkmark$ & $\checkmark$ & $\checkmark$ & $\checkmark$ & $\checkmark$ & $\checkmark$ & $\checkmark$ & $\checkmark$ & $\checkmark$ & $\checkmark$ & $\checkmark$ & $\checkmark$ & $\checkmark$ & s \\
\hline ECHR P6 (death penalty) & $\checkmark$ & $\checkmark$ & $\checkmark$ & $\checkmark$ & $\checkmark$ & $\checkmark$ & $\checkmark$ & $\checkmark$ & $\checkmark$ & $\checkmark$ & $\checkmark$ & $\checkmark$ & $\checkmark$ & $\checkmark$ & $\checkmark$ & $\checkmark$ & $\checkmark$ & $\checkmark$ & $\checkmark$ & $\checkmark$ & $\checkmark$ & $\checkmark$ & $\checkmark$ & $\checkmark$ & $\checkmark$ & $\checkmark$ & $\checkmark$ \\
\hline ECHR P7 (criminal appeal) & $\checkmark$ & $\mathrm{s}$ & $\checkmark$ & $\checkmark$ & $\checkmark$ & $\checkmark$ & $\checkmark$ & $\checkmark$ & $\checkmark$ & $\mathrm{s}$ & $\checkmark$ & $\checkmark$ & $\checkmark$ & $\checkmark$ & $\checkmark$ & $\checkmark$ & $\checkmark$ & $\checkmark$ & $\mathrm{s}$ & $\checkmark$ & $\checkmark$ & $\checkmark$ & $\checkmark$ & $\checkmark$ & $\checkmark$ & $\checkmark$ & $x$ \\
\hline ECHR P12 (discrimination) & $\mathrm{s}$ & s & $\mathrm{x}$ & $\checkmark$ & $\mathrm{s}$ & $\mathrm{x}$ & $\mathrm{s}$ & $\checkmark$ & $x$ & $\mathrm{~s}$ & $\mathrm{~s}$ & $\mathrm{~s}$ & $\mathrm{~s}$ & $\mathrm{~s}$ & s & $x$ & $\checkmark$ & $x$ & $\checkmark$ & $\mathrm{x}$ & s & $\checkmark$ & s & s & $\checkmark$ & $\mathrm{x}$ & $\mathrm{x}$ \\
\hline ECHR P13 (death penalty) & $\checkmark$ & $\checkmark$ & $\checkmark$ & $\checkmark$ & $\checkmark$ & $\checkmark$ & $\checkmark$ & $\checkmark$ & $\checkmark$ & $\checkmark$ & $\checkmark$ & $\checkmark$ & $\checkmark$ & $\checkmark$ & $\mathrm{s}$ & $\checkmark$ & $\checkmark$ & $\checkmark$ & $\checkmark$ & $\mathrm{s}$ & $\checkmark$ & $\checkmark$ & $\checkmark$ & $\checkmark$ & $\checkmark$ & $\checkmark$ & $\checkmark$ \\
\hline ECHR P14 (control system) & $\checkmark$ & $\checkmark$ & $\checkmark$ & $\checkmark$ & $\checkmark$ & $\checkmark$ & $\checkmark$ & $\checkmark$ & $\checkmark$ & $\checkmark$ & $\checkmark$ & $\checkmark$ & $\checkmark$ & $\checkmark$ & $\checkmark$ & $\checkmark$ & $\checkmark$ & $\checkmark$ & $\checkmark$ & $\checkmark$ & $\checkmark$ & $\checkmark$ & $\checkmark$ & $\checkmark$ & $\checkmark$ & $\checkmark$ & $\checkmark$ \\
\hline ECHR P14bis & $\mathrm{s}$ & $\mathrm{x}$ & $x$ & $\mathrm{~s}$ & $\mathrm{x}$ & $\checkmark$ & $\mathrm{x}$ & $x$ & $\mathrm{~s}$ & $\mathrm{x}$ & $\mathrm{x}$ & $\mathrm{s}$ & $\checkmark$ & $\mathrm{x}$ & $\mathrm{x}$ & $x$ & $\mathrm{~s}$ & $\mathrm{x}$ & $\mathrm{x}$ & $\mathrm{s}$ & $\mathrm{x}$ & $\mathrm{s}$ & $\mathrm{s}$ & $\checkmark$ & $\mathrm{s}$ & $\checkmark$ & $\mathrm{x}$ \\
\hline $\mathrm{ESC}(\mathrm{rev})^{\star \star}$ & $\mathrm{s}$ & $\checkmark$ & $\checkmark$ & $\checkmark$ & $\mathrm{s}$ & $\mathrm{s}$ & $\checkmark$ & $\checkmark$ & $\checkmark$ & $\mathrm{s}$ & $\mathrm{s}$ & $\checkmark$ & $\checkmark$ & $\checkmark$ & s & $\checkmark$ & $\mathrm{s}$ & $\checkmark$ & $\checkmark$ & s & $\checkmark$ & $\checkmark$ & $\checkmark$ & $\checkmark$ & $\mathrm{s}$ & $\checkmark$ & $\mathrm{s}$ \\
\hline ESC Prot. Collective Complaints & $\mathrm{s}$ & $\checkmark$ & $\checkmark$ & $\checkmark$ & $\mathrm{s}$ & $\mathrm{s}$ & $\mathrm{s}$ & $\checkmark$ & $\checkmark$ & $\mathrm{s}$ & $\checkmark$ & $\mathrm{s}$ & $\checkmark$ & $\checkmark$ & s & $\mathrm{s}$ & $\mathrm{s}$ & $\mathrm{s}$ & $\checkmark$ & $\mathrm{s}$ & $\checkmark$ & s & $\mathrm{s}$ & $\checkmark$ & $\mathrm{s}$ & $\checkmark$ & $\mathrm{s}$ \\
\hline FCNM & $\checkmark$ & $\mathrm{s}$ & $\checkmark$ & $\checkmark$ & $\checkmark$ & $\checkmark$ & $\checkmark$ & $\checkmark$ & $x$ & $\checkmark$ & $\mathrm{s}$ & $\checkmark$ & $\checkmark$ & $\checkmark$ & $\checkmark$ & $\checkmark$ & $\mathrm{s}$ & $\checkmark$ & $\checkmark$ & $\checkmark$ & $\checkmark$ & $\checkmark$ & $\checkmark$ & $\checkmark$ & $\checkmark$ & $\checkmark$ & $\checkmark$ \\
\hline CRML & $\checkmark$ & $\mathrm{x}$ & $\mathrm{x}$ & $\checkmark$ & $\checkmark$ & $\checkmark$ & $\mathrm{x}$ & $\checkmark$ & $\mathrm{s}$ & $\checkmark$ & $\mathrm{x}$ & $\checkmark$ & $\mathrm{x}$ & $\mathrm{s}$ & $x$ & $x$ & $\checkmark$ & $\mathrm{s}$ & $\checkmark$ & $\checkmark$ & $x$ & $\checkmark$ & $\checkmark$ & $\checkmark$ & $\checkmark$ & $\checkmark$ & $\checkmark$ \\
\hline ECPT & $\checkmark$ & $\checkmark$ & $\checkmark$ & $\checkmark$ & $\checkmark$ & $\checkmark$ & $\checkmark$ & $\checkmark$ & $\checkmark$ & $\checkmark$ & $\checkmark$ & $\checkmark$ & $\checkmark$ & $\checkmark$ & $\checkmark$ & $\checkmark$ & $\checkmark$ & $\checkmark$ & $\checkmark$ & $\checkmark$ & $\checkmark$ & $\checkmark$ & $\checkmark$ & $\checkmark$ & $\checkmark$ & $\checkmark$ & $\checkmark$ \\
\hline CATHB & $\checkmark$ & $\checkmark$ & $\checkmark$ & $\checkmark$ & $x$ & $\checkmark$ & $s$ & $s$ & $\checkmark$ & $s$ & $s$ & s & $s$ & $s$ & $\checkmark$ & $\mathrm{s}$ & $\checkmark$ & $\checkmark$ & $\checkmark$ & $\checkmark$ & $\checkmark$ & $\checkmark$ & $\checkmark$ & $\checkmark$ & $\checkmark$ & $\mathrm{s}$ & $\checkmark$ \\
\hline
\end{tabular}

Notes: * Council of Europe conventions in the field of human rights include the ECHR and its optional protocols, the European Social Charter, the Framework Convention for the Protection of National Minorities, and the European Charter for Regional or Minority Languages, the European Convention for the Prevention of Torture and Inhuman or Degrading Treatment or Punishment, and the Convention on Action against Trafficking in Human Beings. ** All EU Member States are state parties to the original ESC 


\section{Overview of the level of formal commitment of EU Member States to European Social Charter provisions}

Figure A2: Acceptance of provisions of the European Social Charter in the EU27, by country

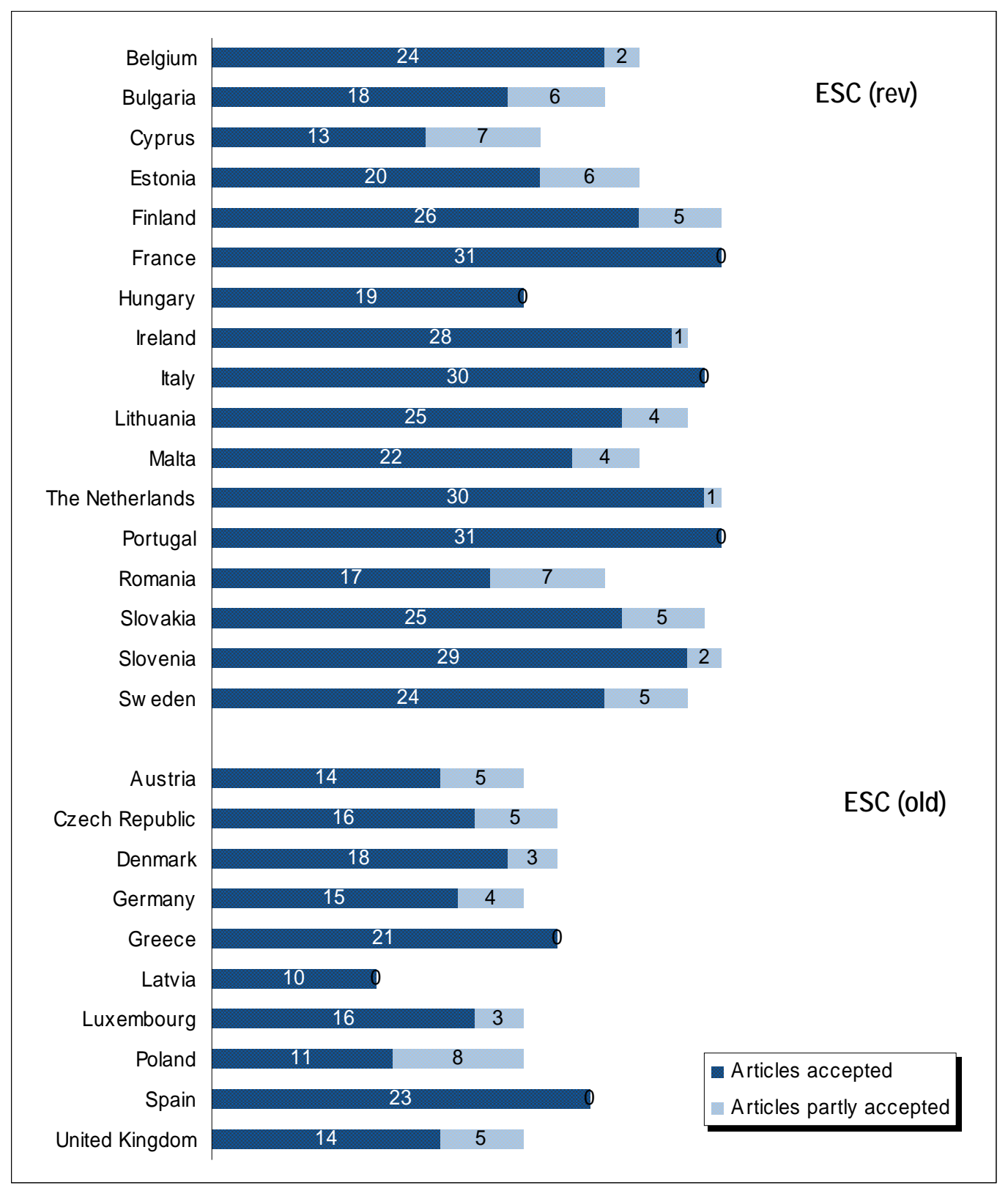

For those countries that have not yet ratified the revised Charter, the acceptance rate of provisions of the original Charter (including its additional protocol) has been taken into account.

"State parties have to accept at least 6 of the 9 articles of the 'hard core' provisions of the Charter (Articles 1 (right to work), 5 (freedom of association), 6 (collective bargaining), 7 (right of children and young persons to protection), 12 (right to social security), 13 (right to social and medical assistance), 16 (right of the family to social, legal and economic protection), 19 (right of migrant workers and their families to protection) and 20 (right to equal opportunities and 
equal treatment in matters of employment and occupation without discrimination on the grounds of sex) and select an additional number of articles or numbered paragraphs to be bound by.

The total number of articles or numbered paragraphs by which every state is bound is not less than 16 articles or 63 numbered paragraphs."

(see: http://www.coe.int/T/DGHL/Monitoring/SocialCharter/) 
Table A3: Overview of the level of formal commitment of the EU Member States to different provisions of the European Social Charter, by country

\begin{tabular}{|c|c|c|c|c|c|c|c|c|c|c|c|c|c|c|c|c|c|c|c|c|c|c|c|c|c|c|c|}
\hline Country & 匡 & BG & Cr & ⿷ & $\mathbf{P}$ & $\mathbf{R}$ & HU & $\mathbf{E}$ & $\pi$ & $\mathbf{L T}$ & MT & $\mathbf{N}$ & $\mathbf{P T}$ & ro & $\mathbf{s}$ & $\mathbf{s}$ & 王 & AT & $\mathbf{z}$ & DK & DE & ㅂ. & $\mathbf{L V}$ & $w$ & $\mathbf{R L}$ & ES & $\mathbf{u k}$ \\
\hline Total accepted & 24 & 18 & 13 & 20 & 26 & 31 & 19 & 28 & 30 & 25 & 22 & 30 & 31 & 17 & 25 & 29 & 24 & 14 & 16 & 18 & 15 & 21 & 10 & 16 & 11 & 23 & 14 \\
\hline Art 1 - right to work & $\checkmark$ & $\checkmark$ & $\checkmark$ & $\checkmark$ & $\checkmark$ & $\checkmark$ & $\checkmark$ & $\checkmark$ & $\checkmark$ & $\checkmark$ & $\checkmark$ & $\checkmark$ & $\checkmark$ & $\checkmark$ & $\checkmark$ & $\checkmark$ & $\checkmark$ & $\checkmark$ & $1 / 2$ & $\checkmark$ & $\checkmark$ & $\checkmark$ & $\checkmark$ & $\checkmark$ & $\checkmark$ & $\checkmark$ & $\checkmark$ \\
\hline Art 2 - just conditions of work & $\checkmark$ & $1 / 2$ & $1 / 2$ & $1 / 2$ & $\checkmark$ & $\checkmark$ & $\checkmark$ & $\checkmark$ & $\checkmark$ & $\checkmark$ & $1 / 2$ & $\checkmark$ & $\checkmark$ & $1 / 2$ & $\checkmark$ & $\checkmark$ & $1 / 2$ & $1 / 2$ & $\checkmark$ & $1 / 2$ & $\checkmark$ & $\checkmark$ & $\mathrm{x}$ & $\checkmark$ & $1 / 2$ & $\checkmark$ & $1 / 2$ \\
\hline Art 3 - safe and healthy work conditions & $\checkmark$ & $\checkmark$ & $1 / 2$ & $1 / 2$ & $1 / 2$ & $\checkmark$ & $\checkmark$ & $\checkmark$ & $\checkmark$ & $\checkmark$ & $\checkmark$ & $\checkmark$ & $\checkmark$ & $1 / 2$ & $\checkmark$ & $\checkmark$ & $1 / 2$ & $\checkmark$ & $\checkmark$ & $\checkmark$ & $\checkmark$ & $\checkmark$ & $\mathrm{x}$ & $\checkmark$ & $\checkmark$ & $\checkmark$ & $\checkmark$ \\
\hline Art 4 - fair remuneration & $\checkmark$ & $1 / 2$ & $x$ & $1 / 2$ & $1 / 2$ & $\checkmark$ & $\mathrm{x}$ & $\checkmark$ & $\checkmark$ & $\checkmark$ & $\checkmark$ & $\checkmark$ & $\checkmark$ & $\checkmark$ & $\checkmark$ & $\checkmark$ & $1 / 2$ & $1 / 2$ & $1 / 2$ & $1 / 2$ & $1 / 2$ & $\checkmark$ & $x$ & $1 / 2$ & $1 / 2$ & $\checkmark$ & $1 / 2$ \\
\hline Art 5 - right to organise & $\checkmark$ & $\checkmark$ & $\checkmark$ & $\checkmark$ & $\checkmark$ & $\checkmark$ & $\checkmark$ & $\checkmark$ & $\checkmark$ & $\checkmark$ & $\checkmark$ & $\checkmark$ & $\checkmark$ & $\checkmark$ & $\checkmark$ & $\checkmark$ & $\checkmark$ & $\checkmark$ & $\checkmark$ & $\checkmark$ & $\checkmark$ & $x$ & $\checkmark$ & $\checkmark$ & $\checkmark$ & $\checkmark$ & $\checkmark$ \\
\hline Art 6 - right to bargain collectively & $\checkmark$ & $\checkmark$ & $\checkmark$ & $\checkmark$ & $\checkmark$ & $\checkmark$ & $\checkmark$ & $\checkmark$ & $\checkmark$ & $\checkmark$ & $\checkmark$ & $\checkmark$ & $\checkmark$ & $\checkmark$ & $\checkmark$ & $\checkmark$ & $\checkmark$ & $1 / 2$ & $\checkmark$ & $\checkmark$ & $\checkmark$ & $\mathrm{x}$ & $\checkmark$ & $1 / 2$ & $1 / 2$ & $\checkmark$ & $\checkmark$ \\
\hline Art 7 - protection of children and young persons & $\checkmark$ & $\checkmark$ & $1 / 2$ & $1 / 2$ & $1 / 2$ & $\checkmark$ & $\checkmark$ & $\checkmark$ & $\checkmark$ & $\checkmark$ & $\checkmark$ & $\checkmark$ & $\checkmark$ & $\checkmark$ & $\checkmark$ & $\checkmark$ & $1 / 2$ & $1 / 2$ & $\checkmark$ & $\mathrm{x}$ & $1 / 2$ & $\checkmark$ & $\mathrm{x}$ & $\checkmark$ & $1 / 2$ & $\checkmark$ & $1 / 2$ \\
\hline Art 8 - protection of maternity of employed women & $\checkmark$ & $\checkmark$ & $1 / 2$ & $\checkmark$ & $1 / 2$ & $\checkmark$ & $\checkmark$ & $1 / 2$ & $\checkmark$ & $\checkmark$ & $1 / 2$ & $\checkmark$ & $\checkmark$ & $\checkmark$ & $\checkmark$ & $\checkmark$ & $1 / 2$ & $\checkmark$ & $\checkmark$ & $1 / 2$ & $1 / 2$ & $\checkmark$ & $\checkmark$ & $1 / 2$ & $\checkmark$ & $\checkmark$ & $1 / 2$ \\
\hline Art 9 - vocational guidance & $\checkmark$ & $\mathrm{x}$ & $\checkmark$ & $\checkmark$ & $\checkmark$ & $\checkmark$ & $\checkmark$ & $\checkmark$ & $\checkmark$ & $\checkmark$ & $\checkmark$ & $\checkmark$ & $\checkmark$ & $\checkmark$ & $\checkmark$ & $\checkmark$ & $\checkmark$ & $\checkmark$ & $x$ & $\checkmark$ & $\checkmark$ & $\checkmark$ & $\checkmark$ & $\checkmark$ & $\checkmark$ & $\checkmark$ & $\checkmark$ \\
\hline Art 10 - vocational training & $\checkmark$ & $x$ & $\checkmark$ & $1 / 2$ & $\checkmark$ & $\checkmark$ & $\checkmark$ & $\checkmark$ & $\checkmark$ & $\checkmark$ & $\checkmark$ & $\checkmark$ & $\checkmark$ & $x$ & $\checkmark$ & $\checkmark$ & $\checkmark$ & $\checkmark$ & $x$ & $\checkmark$ & $1 / 2$ & $\checkmark$ & $x$ & $\checkmark$ & $1 / 2$ & $\checkmark$ & $\checkmark$ \\
\hline Art 11 - protection of health & $\checkmark$ & $\checkmark$ & $\checkmark$ & $\checkmark$ & $\checkmark$ & $\checkmark$ & $\checkmark$ & $\checkmark$ & $\checkmark$ & $\checkmark$ & $\checkmark$ & $\checkmark$ & $\checkmark$ & $\checkmark$ & $\checkmark$ & $\checkmark$ & $\checkmark$ & $\checkmark$ & $\checkmark$ & $\checkmark$ & $\checkmark$ & $\checkmark$ & $\checkmark$ & $\checkmark$ & $\checkmark$ & $\checkmark$ & $\checkmark$ \\
\hline Art 12 - social security & $\checkmark$ & $\checkmark$ & $\checkmark$ & $\checkmark$ & $\checkmark$ & $\checkmark$ & $\checkmark$ & $\checkmark$ & $\checkmark$ & $\checkmark$ & $\checkmark$ & $\checkmark$ & $\checkmark$ & $\checkmark$ & $\checkmark$ & $\checkmark$ & $\checkmark$ & $\checkmark$ & $\checkmark$ & $\checkmark$ & $\checkmark$ & $\checkmark$ & $\mathrm{x}$ & $\checkmark$ & $\checkmark$ & $\checkmark$ & $1 / 2$ \\
\hline Art 13 - social and medical assistance & $\checkmark$ & $1 / 2$ & $1 / 2$ & $1 / 2$ & $\checkmark$ & $\checkmark$ & $\checkmark$ & $\checkmark$ & $\checkmark$ & $1 / 2$ & $\checkmark$ & $\checkmark$ & $\checkmark$ & $1 / 2$ & $1 / 2$ & $1 / 2$ & $\checkmark$ & $\checkmark$ & $\checkmark$ & $\checkmark$ & $\checkmark$ & $\checkmark$ & $\checkmark$ & $\checkmark$ & $1 / 2$ & $\checkmark$ & $\checkmark$ \\
\hline Art 14 - benefit from social welfare services & $\checkmark$ & $\checkmark$ & $\checkmark$ & $\checkmark$ & $\checkmark$ & $\checkmark$ & $\checkmark$ & $\checkmark$ & $\checkmark$ & $\checkmark$ & $\checkmark$ & $\checkmark$ & $\checkmark$ & $x$ & $\checkmark$ & $\checkmark$ & $\checkmark$ & $\checkmark$ & $\checkmark$ & $\checkmark$ & $\checkmark$ & $\checkmark$ & $\checkmark$ & $\checkmark$ & $1 / 2$ & $\checkmark$ & $\checkmark$ \\
\hline Art 15 - persons with disabilities & $\checkmark$ & $\mathrm{x}$ & $\checkmark$ & $\checkmark$ & $\checkmark$ & $\checkmark$ & $\checkmark$ & $\checkmark$ & $\checkmark$ & $\checkmark$ & $\checkmark$ & $\checkmark$ & $\checkmark$ & $1 / 2$ & $1 / 2$ & $\checkmark$ & $\checkmark$ & $\checkmark$ & $1 / 2$ & $\checkmark$ & $\checkmark$ & $\checkmark$ & $\mathrm{x}$ & $\checkmark$ & $\checkmark$ & $\checkmark$ & $\checkmark$ \\
\hline Art 16 - protection of the family & $\checkmark$ & $\checkmark$ & $x$ & $\checkmark$ & $\checkmark$ & $\checkmark$ & $\checkmark$ & $\checkmark$ & $\checkmark$ & $\checkmark$ & $\checkmark$ & $\checkmark$ & $\checkmark$ & $\checkmark$ & $\checkmark$ & $\checkmark$ & $\checkmark$ & $\checkmark$ & $\checkmark$ & $\checkmark$ & $\checkmark$ & $\checkmark$ & $\checkmark$ & $\checkmark$ & $\checkmark$ & $\checkmark$ & $\checkmark$ \\
\hline Art 17 - protection of children and young persons & $\checkmark$ & $1 / 2$ & $\mathrm{x}$ & $\checkmark$ & $\checkmark$ & $\checkmark$ & $\checkmark$ & $\checkmark$ & $\checkmark$ & $\checkmark$ & $\checkmark$ & $\checkmark$ & $\checkmark$ & $\checkmark$ & $\checkmark$ & $\checkmark$ & $\checkmark$ & $\checkmark$ & $\checkmark$ & $\checkmark$ & $\checkmark$ & $\checkmark$ & $\checkmark$ & $\checkmark$ & $\checkmark$ & $\checkmark$ & $\checkmark$ \\
\hline Art 18 - work in the territory of other Parties & $\checkmark$ & $1 / 2$ & $1 / 2$ & $\mathrm{x}$ & $\checkmark$ & $\checkmark$ & $\mathrm{x}$ & $\checkmark$ & $\checkmark$ & $1 / 2$ & $1 / 2$ & $\checkmark$ & $\checkmark$ & $1 / 2$ & $1 / 2$ & $1 / 2$ & $\checkmark$ & $\checkmark$ & $1 / 2$ & $\checkmark$ & $\checkmark$ & $\checkmark$ & $\mathrm{x}$ & $\checkmark$ & $1 / 2$ & $\checkmark$ & $\checkmark$ \\
\hline Art 19 - protection and assistance of migrant workers & $1 / 2$ & $\mathrm{x}$ & $\checkmark$ & $\checkmark$ & $1 / 2$ & $\checkmark$ & $\mathrm{x}$ & $\checkmark$ & $\checkmark$ & $1 / 2$ & $\mathrm{x}$ & $1 / 2$ & $\checkmark$ & $1 / 2$ & $1 / 2$ & $\checkmark$ & $\checkmark$ & $1 / 2$ & $1 / 2$ & $\mathrm{x}$ & $\checkmark$ & $\checkmark$ & $\mathrm{x}$ & $\checkmark$ & $\checkmark$ & $\checkmark$ & $\checkmark$ \\
\hline Art 20 - non-discrimination on the grounds of sex & $\checkmark$ & $\checkmark$ & $\checkmark$ & $\checkmark$ & $\checkmark$ & $\checkmark$ & $\checkmark$ & $\checkmark$ & $\checkmark$ & $\checkmark$ & $\checkmark$ & $\checkmark$ & $\checkmark$ & $\checkmark$ & $\checkmark$ & $\checkmark$ & $\checkmark$ & $\mathrm{x}$ & $\checkmark$ & $\checkmark$ & $\mathrm{x}$ & $\checkmark$ & $\mathrm{x}$ & $x$ & $\mathrm{x}$ & $\checkmark$ & $\mathrm{x}$ \\
\hline Art 21 - information and consultation & $\checkmark$ & $\checkmark$ & $\mathrm{x}$ & $\checkmark$ & $\checkmark$ & $\checkmark$ & $\checkmark$ & $x$ & $\checkmark$ & $\checkmark$ & $\mathrm{x}$ & $\checkmark$ & $\checkmark$ & $\checkmark$ & $\checkmark$ & $\checkmark$ & $\checkmark$ & $\mathrm{x}$ & $\checkmark$ & $\checkmark$ & $\mathrm{x}$ & $\checkmark$ & $x$ & $x$ & $x$ & $\checkmark$ & $x$ \\
\hline Art 22 - participation in improvement of working conditions & $\checkmark$ & $\checkmark$ & $\mathrm{x}$ & $\checkmark$ & $\checkmark$ & $\checkmark$ & $\checkmark$ & $\checkmark$ & $\checkmark$ & $\checkmark$ & $\mathrm{x}$ & $\checkmark$ & $\checkmark$ & $\mathrm{x}$ & $\checkmark$ & $\checkmark$ & $\checkmark$ & $\mathrm{x}$ & $\checkmark$ & $\checkmark$ & $\mathrm{x}$ & $\checkmark$ & $\mathrm{x}$ & $\mathrm{x}$ & $\mathrm{x}$ & $\checkmark$ & $\mathrm{x}$ \\
\hline
\end{tabular}




\begin{tabular}{|c|c|c|c|c|c|c|c|c|c|c|c|c|c|c|c|c|c|c|c|c|c|c|c|c|c|c|c|}
\hline Country & ⿷匚 & $B G$ & cr & 匝 & म & $\mathbf{R}$ & HU & $\mathbf{E}$ & $\mathbf{\pi}$ & $\mathbf{L T}$ & мт & $\mathbf{N}$ & $\mathbf{P T}$ & Ro & $\mathbf{s k}$ & $\mathbf{s}$ & $\mathbf{\Phi}$ & AT & $\mathbf{z}$ & DK & DE & 旦 & LV & ш & $\mathbf{R L}$ & Es & $\mathbf{~ u K}$ \\
\hline Art 23 - social protection of elderly persons & $\mathrm{x}$ & $\mathrm{x}$ & $\mathrm{x}$ & $\mathrm{x}$ & $\checkmark$ & $\checkmark$ & $\mathrm{x}$ & $\checkmark$ & 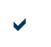 & $\mathrm{x}$ & r & $\checkmark$ & $\checkmark$ & $\mathrm{x}$ & 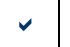 & $\checkmark$ & $\checkmark$ & $\mathrm{x}$ & $\checkmark$ & 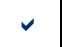 & $\mathrm{x}$ & 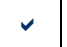 & $\mathrm{x}$ & $\mathrm{x}$ & $\mathrm{x}$ & 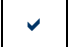 & $x$ \\
\hline Art 24 - protection in cases of termination of employment & $\mathrm{x}$ & r & $\checkmark$ & $\checkmark$ & v & v & $\mathrm{x}$ & $\checkmark$ & 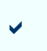 & v & v & v & v & r & v & v & $\mathrm{x}$ & \multirow{8}{*}{\multicolumn{10}{|c|}{$\begin{array}{l}\text { AT, CZ, DK, DE, EL, LV, LU, PL, } \\
\text { ES, UK have not yet ratified the } \\
\text { revised Social Charter. Art } 20-23 \\
\text { correspond to Art } 1-4 \text { of the } \\
\text { additional protocol to the original } \\
\text { Social Charter. }\end{array}$}} \\
\hline Art 25 - protection in case of employer's insolvency & r & $\checkmark$ & $\mathrm{x}$ & r & $\mathrm{v}$ & $\mathrm{v}$ & $\mathrm{x}$ & $\checkmark$ & $\mathrm{x}$ & $\mathrm{v}$ & v & 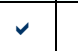 & 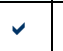 & r & v & v & r & & & & & & & & & & \\
\hline Art 26 - dignity at work & $1 / 2$ & $\checkmark$ & $\mathrm{x}$ & $x$ & $\checkmark$ & $\checkmark$ & $\mathrm{x}$ & $\checkmark$ & $\checkmark$ & $\checkmark$ & v & $\checkmark$ & $\checkmark$ & $\mathrm{x}$ & $\checkmark$ & $\checkmark$ & $\checkmark$ & & & & & & & & & & \\
\hline Art 27 - workers with family responsibilities & $\mathrm{x}$ & $1 / 2$ & $1 / 2$ & $\checkmark$ & $\checkmark$ & $\checkmark$ & $\mathrm{x}$ & $\checkmark$ & $\checkmark$ & $\checkmark$ & $1 / 2$ & $\checkmark$ & $\checkmark$ & $1 / 2$ & $1 / 2$ & $\checkmark$ & $\checkmark$ & & & & & & & & & & \\
\hline Art 28 - protection of workers' representatives & $\mathrm{x}$ & $\checkmark$ & $\checkmark$ & $r$ & $\checkmark$ & r & $\mathrm{x}$ & $\checkmark$ & $\checkmark$ & - & v & - & $\checkmark$ & $\checkmark$ & $\checkmark$ & $\checkmark$ & $\mathrm{x}$ & & & & & & & & & & \\
\hline Art 29 - consultation in collective redundancy procedures & $\checkmark$ & 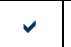 & $\mathrm{x}$ & r & $\checkmark$ & $\checkmark$ & $x$ & $\checkmark$ & $\checkmark$ & 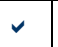 & v & 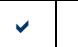 & $\checkmark$ & $\checkmark$ & $\checkmark$ & v & r & & & & & & & & & & \\
\hline Art 30 - protection against poverty and social exclusion & $\checkmark$ & $\mathrm{x}$ & $\mathrm{x}$ & $\mathrm{x}$ & $\checkmark$ & v & $\mathrm{x}$ & $\checkmark$ & $\checkmark$ & $\mathrm{x}$ & $\mathrm{x}$ & v & v & $\mathrm{x}$ & $\checkmark$ & v & $\checkmark$ & & & & & & & & & & \\
\hline Art 31 - housing & $\mathrm{x}$ & $\mathrm{x}$ & $\mathrm{x}$ & $\mathrm{x}$ & $\checkmark$ & r & $\mathrm{x}$ & $\mathrm{x}$ & 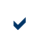 & $1 / 2$ & $\mathrm{x}$ & $\checkmark$ & $\checkmark$ & $\mathrm{x}$ & $\mathrm{x}$ & v & r & & & & & & & & & & \\
\hline
\end{tabular}




\section{Annex 2: Country codes}

\begin{tabular}{|l|l|}
\hline AT & Austria \\
\hline BE & Belgium \\
\hline BG & Bulgaria \\
\hline CY & Cyprus \\
\hline CZ & Czech Republic \\
\hline DE & Germany \\
\hline DK & Denmark \\
\hline EE & Estonia \\
\hline EL & Greece \\
\hline ES & Spain \\
\hline FI & Finland \\
\hline FR & France \\
\hline HU & Hungary \\
\hline IE & Ireland \\
\hline IT & Italy \\
\hline LT & Lithuania \\
\hline LU & Luxembourg \\
\hline LV & Latvia \\
\hline MT & Malta \\
\hline NL & The Netherlands \\
\hline PL & Poland \\
\hline PT & Portugal \\
\hline RO & Romania \\
\hline SE & Sweden \\
\hline SI & Slovenia \\
\hline SK & Slovakia \\
\hline UK & United Kingdom \\
\hline
\end{tabular}


European Union Agency for Fundamental Rights

\section{Annual Report 2010}

Conference Edition

$2010-171$ pp, $-21 \times 29.7 \mathrm{~cm}$

A great deal of information on the European Union Agency for Fundamental Rights is available on the Internet. It can be accessed through the FRA website (http://fra.europa.eu).

(c) European Union Agency for Fundamental Rights, 2010

Reproduction is authorised, except for commercial purposes, provided the source is acknowledged.

Design: FRA - Vienna 
FRA - European Union Agency for Fundamental Rights

Schwarzenbergplatz 11

1040 - Wien

Austria

Tel.: +43 (0)1 58030 - 0

Fax: +43(0)158030-691

E-Mail: information@fra.europa.eu

http://fra.europa.eu 